

\author{
UNIVERSIDADE DE BRASÍLIA \\ FACULDADE DE TECNOLOGIA \\ DEPARTAMENTO DE ENGENHARIA FLORESTAL
}

\title{
DINÂMICA DE COMUNIDADES VEGETAIS EM CERRADO TÍPICO COM HISTÓRICO DE FOGO NO DISTRITO FEDERAL
}

MARY NAVES DA SILVA RIOS

ORIENTADOR: Dr. JOSÉ CARLOS SOUSA SILVA

TESE DE DOUTORADO EM CIÊNCIAS FLORESTAIS

PUBLICAÇÃO: PPGEFL.TD065/2016

BRASÍLIA/DF: ABRIL DE 2016 


\author{
UNIVERSIDADE DE BRASÍLIA \\ FACULDADE DE TECNOLOGIA \\ DEPARTAMENTO DE ENGENHARIA FLORESTAL \\ PROGRAMA DE PÓS-GRADUAÇÃO EM CIÊNCIAS FLORESTAIS
"DINÂMICA DE COMUNIDADES VEGETAIS EM CERRADO TÍPICO COM
HISTÓRICO DE FOGO NO DISTRITO FEDERAL"

MARY NAVES DA SILVA RIOS

TESE DE DOUTORADO SUBMETIDA AO PROGRAMA DE PÓSGRADUAÇÃO EM CIÊNCIAS FLORESTAIS, DO DEPARTAMENTO DE ENGENHARIA FLORESTAL, DA FACULDADE DE TECNOLOGIA DA UNIVERSIDADE DE BRASÍLIA, COMO PARTE DOS REQUISITOS NECESSÁRIOS PARA A OBTENÇÃO DO GRAU DE DOUTOR.

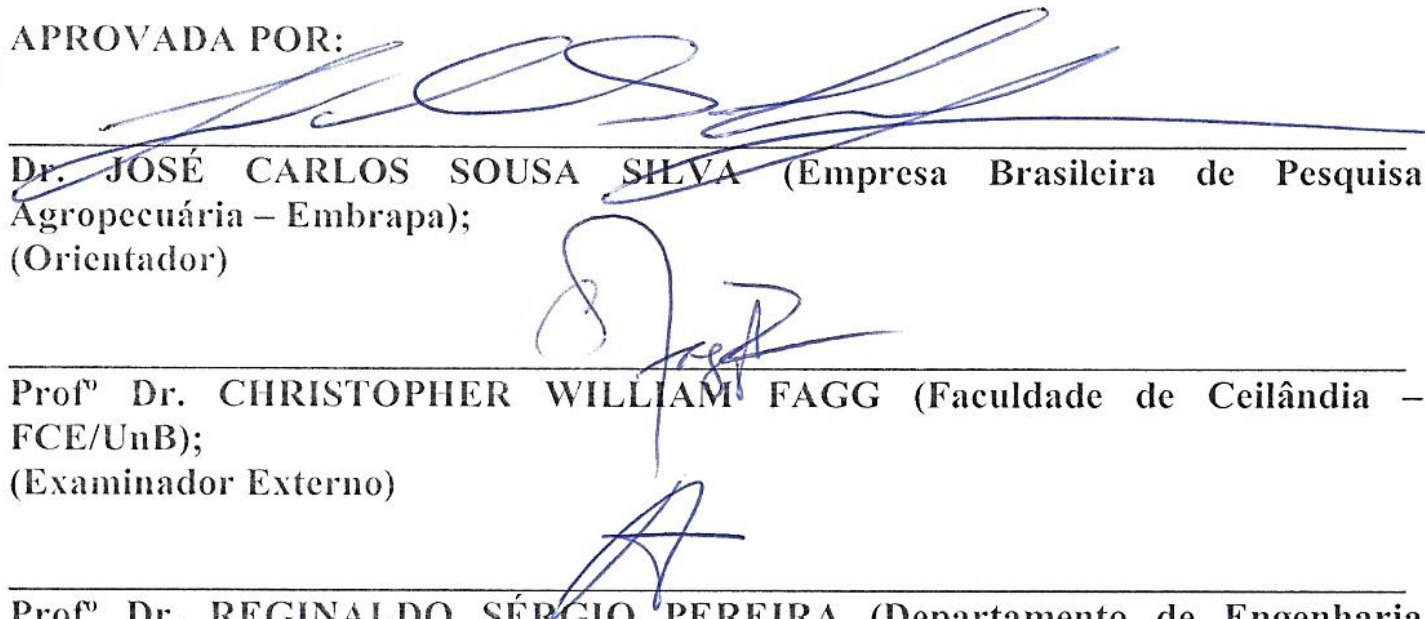
Florestal-EFL/UnB);

(Examinador Interno)

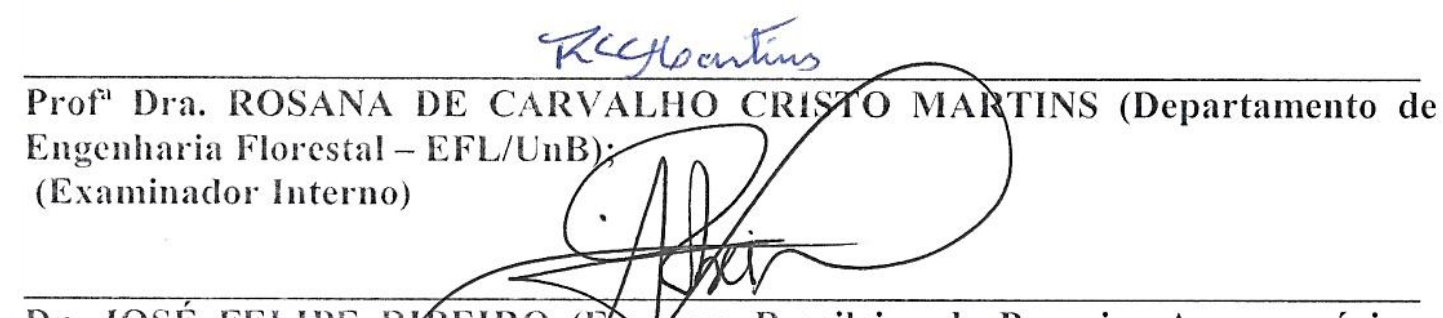

Dr. JOSÉ FELIPE R/BEIRO (BNy resa Brasileira de Pesquisa Agropecuária Embrapa);

(Examinador Externof

\title{
sever Lantee Bage Ramb
}

Dr. ALLAN KARDEC BRAGA RAMOS (Empresa Brasileira de Pesquisa Agropecuária - Embrapa).

(Examinador Suplente)

Brasília-DF, 28 de abril de 2016. 
Ficha catalográfica elaborada automaticamente, com os dados fornecidos pelo(a) autor(a)

R586d

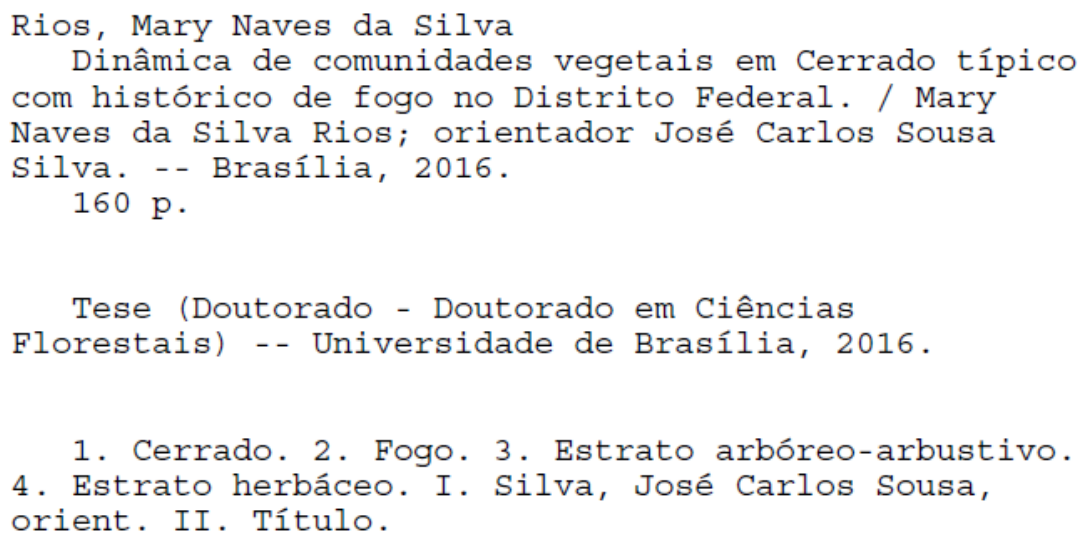

\section{REFERÊNCIA BIBLIOGRÁFICA}

RIOS, M.N.S. Dinâmica de comunidades vegetais em Cerrado típico com histórico de fogo no Distrito Federal. Tese de Doutorado em Ciências Florestais. PPGEFL.TD065/2016, Programa de pós-graduação em Ciências Florestais, Universidade de Brasília, Brasília, DF, $160 \mathrm{p}$.

\section{CESSÃO DE DIREITOS}

AUTORA: Mary Naves da Silva Rios

TÍTULO: Dinâmica de comunidades vegetais em Cerrado típico com histórico de fogo no Distrito Federal.

GRAU: Doutora ANO: 2016 ÀREA DE CONCENTRAÇÃO: Conservação da Natureza

É concedida à Universidade de Brasília permissão para reproduzir cópias desta tese de doutorado e para emprestar ou vender tais cópias somente para propósitos acadêmicos e científicos. $\mathrm{O}$ autor reserva outros direitos de publicação e nenhuma parte dessa tese de doutorado pode ser reproduzida sem autorização por escrito do autor.

Mary Naves da Silva Rios

Endereço eletrônico: mnavesrios@hotmail.com 


\section{AGRADECIMENTOS}

À Coordenação de Aperfeiçoamento de Pessoal de Nível Superior (CAPES) pela bolsa de estudos e apoio financeiro em eventos científicos e trabalho de campo.

À Universidade de Brasília, aos professores e funcionários do Departamento de Engenharia Florestal pelo apoio e amizade durante todo o curso. Aos professores Dra. Alba Valéria Rezende, Dr. Reginaldo Sérgio Pereira, Dra. Rosana de Carvalho Cristo Martins e Dr. Manoel Cláudio da Silva Jr. pelas sugestões e carinho.

Aos funcionários Pedro, Chiquinho, Tiago e Yuri pelo apoio durante o curso. Aos colegas do curso, principalmente, Bruno, Fabrício, Lamartine, Silvia, Pierre, Milton e Tangriene pela amizade.

Ao ex-chefe Dr. José Roberto Rodrigues Peres, e ao atual Chefe da EMBRAPA Cerrados Dr. Cláudio Takao Karia pelo apoio para a realização do trabalho de campo e análise de solos.

Aos pesquisadores da Embrapa Cerrados Dra. Maria Lúcia Meirelles, Dra. Marina de Fátima Vilela, Dr. José Felipe Ribeiro, Dr. Marcos Carolino de Sá Aurélio e Dr. Fernando Antônio Macena da Silva pelo apoio, sugestões e incentivo.

Aos funcionários da EMBRAPA Cerrados, principalmente, ao Nélson de Oliveira Pais, Natália Pedrosa de Sousa F. Vasquez, Valdeci de Matos Lima, José Ferreira Paixão, Osmi Ribeiro Soares, Rubens e Carlão, pelo apoio nos trabalhos de campo, pelo carinho e amizade.

Aos funcionários da biblioteca e do Laboratório de Solos da Embrapa Cerrados, principalmente, ao Francisco Marcos dos Santos Delvico e à Aline Rodrigues Rabello pelo apoio.

Aos professores do Departamento de Botânica da Universidade de Brasília, principalmente, à Dra. Cássia Beatriz Rodrigues Munhoz pelas orientações, carinho e 
amizade. Também às professoras Dra. Lúcia Helena Soares e Silva e Dra. Carolyn Elinore Barnes Proença.

Aos colegas Jair e João pelo apoio junto ao Herbário. Aos colegas e funcionários do Herbário da Universidade de Brasília (UB), principalmente, à Jose, Marina, Daniel e Daniela.

À professora Dra. Heloísa Sinátora Miranda do Departamento de Ecologia, da Universidade de Brasília, pelas sugestões e incentivo. E também ao Dr. Vagner Santiago do Vale pelas orientações de grande importância para o desenvolvimento do trabalho.

Ao meu orientador, José Carlos Sousa Silva, pela valiosa orientação, incentivo, amizade e sugestões recebidas durante a realização deste trabalho.

À minha família, principalmente, aos meus queridos Guilherme, Carol e Rodrigo pela compreensão, paciência, incentivo e apoio para a finalização deste trabalho. 


\title{
RESUMO
}

\section{DINÂMICA DE COMUNIDADES VEGETAIS EM CERRADO TÍPICO COM HISTÓRICO DE FOGO NO DISTRITO FEDERAL}

\author{
Autor: Mary Naves da Silva Rios \\ Orientador: José Carlos Sousa Silva \\ Programa de Pós-graduação em Ciências Florestais
}

Brasília, abril de 2016

O monitoramento da vegetação arbóreo-arbustiva e herbácea foi realizado em duas áreas de Cerrado sentido restrito em Planaltina (DF), de 1988 a 1994 e em 2012. Na Área 1 foram aplicadas queimadas bienais, em agosto de 1988 a 1992; já a Área 2 foi protegida do fogo de 1988 a julho de 1994. Em agosto de 1994 um fogo acidental atingiu as duas áreas, havendo proteção contra o fogo de 1995 a 2012. No monitoramento da vegetação arbóreoarbustiva foram demarcadas 20 parcelas de $10 \mathrm{mx} 10 \mathrm{~m}$ em cada área de 1,25ha; em 1988 eram 10 parcelas de $20 \mathrm{mx} 10 \mathrm{~m}$. Foram medidos o diâmetro e a altura de todos os indivíduos arbóreo-arbustivos que atingiam um metro ou mais de altura. A dinâmica da comunidade arbóreo-arbustiva foi analisada de 1991 a 1994. A biomassa aérea da vegetação arbóreo-arbustiva foi estimada de 1990 a 1994 e em 2012. A formação de rebrotas foi avaliada para espécies arbóreo-arbustivas que rebrotaram da base do caule e de estruturas subterrâneas, nas duas áreas. A formação de grupos funcionais foi avaliada de acordo com atributos funcionais das espécies arbóreo-arbustivas em 1994 e em 2012. No monitoramento da vegetação do estrato herbáceo foi empregado o método de interceptação na linha, onde foram anotadas as espécies até a altura de um metro. Análises florísticas e fitossociológicas foram feitas para o período de 1988 a 2012. Os resultados do levantamento das espécies arbóreo-arbustivas no período de 1988 a 2012 evidenciaram mudanças relacionadas à composição florística e à estrutura da comunidade. A riqueza de espécies se manteve, mas houve diferenças na diversidade entre a Área 1 e a Área 2. As duas áreas apresentaram similaridade florística em 2012. As queimadas bienais reduziram a densidade e a área basal, porém, a proteção contra o fogo, por 18 anos, aumentou a densidade e a área basal, nas duas áreas. A distribuição dos indivíduos vivos em classes de altura e de diâmetro, nas duas áreas, foi similar em todo período do estudo, no entanto, o fogo afetou, principalmente, os indivíduos nas menores classes de altura e de diâmetro. Os resultados de dinâmica mostraram que a incidência de queimadas aumentou a mortalidade e reduziu o recrutamento de indivíduos, e a proteção contra o fogo proporcionou maiores taxas de recrutamento e menores de mortalidade. A Área 1 foi mais dinâmica que a Área 2, com menores valores de tempo de meia vida e de substituição. A incidência de queimadas bienais diminuiu a biomassa aérea estimada no período de 1990 a 1994; a proteção contra o fogo por 18 anos favoreceu o aumento da biomassa aérea nas duas áreas. A incidência de queimadas bienais favoreceu a reprodução assexuada, com rebrotas basais ou subterrâneas na Área 1. Houve diferenças nos grupos funcionais formados nas duas áreas. A maior frequência do fogo, na Área 1, em 1994, reuniu espécies funcionalmente semelhantes, com menor diversidade de atributos. Por outro lado, o tempo de exclusão do fogo favoreceu algumas espécies e a maior diversidade de atributos em 2012. Quanto ao estrato herbáceo os resultados mostraram que as queimadas bienais não modificaram a riqueza e a diversidade no período de 1988 a 1994, e em 2012. A menor diversidade foi observada em 1988 e a maior em 1994, nas duas áreas; em 2012 a diversidade foi menor do que em 1994. Palavras-chave: fogo, estrutura, fitossociologia, diversidade funcional, biomassa, reprodução vegetativa, camada herbácea, camada arbóreo-arbustiva 


\section{ABSTRACT \\ DYNAMICS OF THE PLANT COMMUNITY OF A TYPICAL CERRADO WITH FIRE HISTORY IN THE DISTRITO FEDERAL}

The monitoring of trees and shrubs and herbaceous vegetation was conducted in a Cerrado stricto sensu in Planaltina (DF), from 1988 to 2012 in two areas (Area 1, Area 2). The biennial fire regime was applied only in Area 1 in August, from 1988 to 1992. There was an accidental burning in 1994 which occurred in both areas. The two areas were protected against fire from 1995 to 2012. The data of trees and shrubs community were collected in 20 plots of $10 \mathrm{mx} 10 \mathrm{~m}$ in each area; only in 1988 the plots were $20 \mathrm{mx} 10 \mathrm{~m}$. The diameter and height of trees and shrubs $\geq 1 \mathrm{~m}$ height were measured. An analysis was made of the floristic composition and structure of the shrub-arboreal layer for the period 1988-2012. The dynamics of the shrub-arboreal community was analyzed 1991-1994. The biomass of shrub-arboreal vegetation was estimated from 1990 to 1994 and in 2012. The sprouting capacity was evaluated for tree and shrub species. The formation of functional groups was evaluated according to functional attributes of tree and shrub species, in 1994 and 2012. The attributes were related to disturbance by fire. The line intercept method was adopted for sampling the herbaceous layer. In the herbaceous layer were recorded species with less than one meter height. An analysis was made of the floristic composition and structure of the herbaceous layer for the period 1988-2012. The survey of tree and shrub species showed changes in the floristic composition and structure in the period of 1988-1994 and in 2012. The species richness remained. There were differences in diversity between Area 1 and Area 2. The two areas have floristic similarity in 2012. The biennial fire reduced the density and the basal area. The fire protection increased the density and basal area. The distribution of living individuals in height and diameter class were similar throughout the study period, however, the fire affected individuals in the smaller diameter and height classes. The dynamic results showed that the biennial fire increased mortality and reduced the recruitment of individuals; the fire protection provided higher rates of recruitment and lower mortality rates. Area 1 was more dynamic than the Area 2 with lower values of halflife and turnover rates. The incidence of biennial fire decreased aboveground biomass. The fire protection for 18 years increased the aboveground biomass in the two areas. The biennial fire favors asexual reproduction with basal or underground sprouts in the Area 1. There were differences in the formation of functional groups in the two areas. The highest frequency of fire in the Area 1, in 1994, brought together functionally similar species and reduced diversity of attributes. On the other hand, the fire exclusion favors certain species and increased diversity of attributes in 2012. The analysis of the herbaceous layer showed that the biennial fires did not change the species richness and diversity in the period of 1988 to 1994 and in 2012. The lower diversity was observed in 1988 and the higher diversity was observed in 1994, in both areas. In 2012, the diversity was lower than in 1994.

Key-words: structure, phytosociology, functional diversity, biomass, resprouting, herbaceous layer, shrub-arboreal layer. 
SUMÁRIO

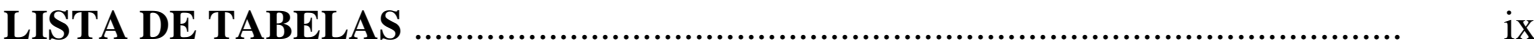

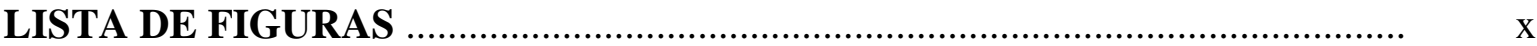

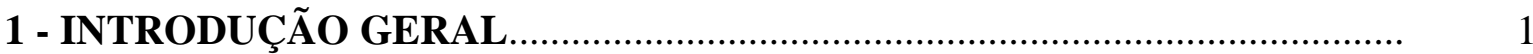

2 - MUDANÇAS PÓS-FOGO NA FLORÍSTICA E ESTRUTURA DA VEGETAÇÃO ARBÓREO-ARBUSTIVA EM UM FRAGMENTO DE CERRADO SENTIDO RESTRITO NO DISTRITO FEDERAL ........................

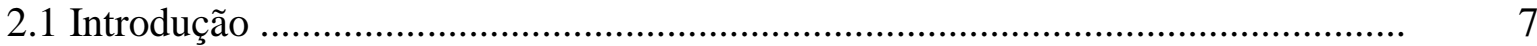

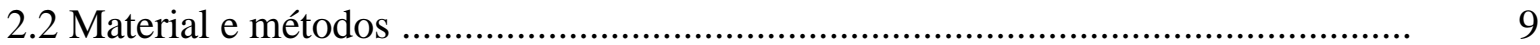

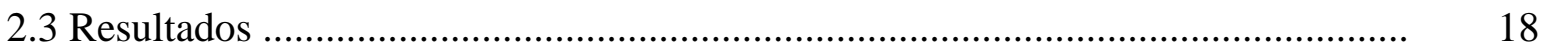

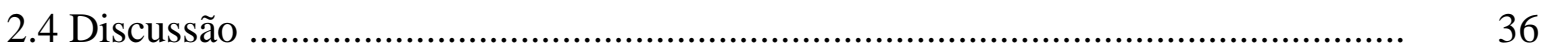

2.5 Conclusões

3 - DINÂMICA PÓS-FOGO DA VEGETAÇÃO ARBÓREO-ARBUSTIVA EM UM FRAGMENTO DE CERRADO SENTIDO RESTRITO NO DISTRITO FEDERAL

3.1 Introdução

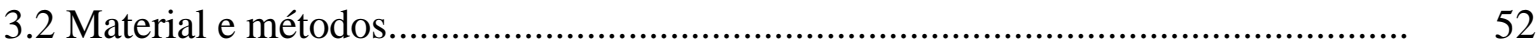

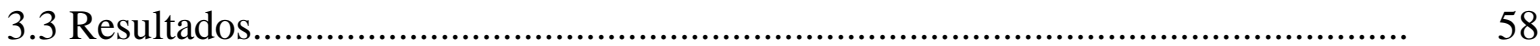

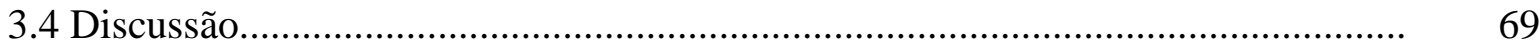

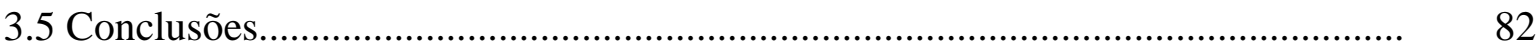

4 - MUDANÇAS NA VEGETAÇÃO HERBÁCEA EM ÁREA DE CERRADO SENTIDO RESTRITO COM DIFERENTES HISTÓRICOS DE QUEIMADAS, NO DISTRITO FEDERAL …………………………………... 83

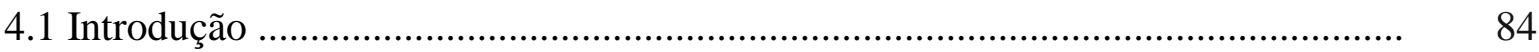

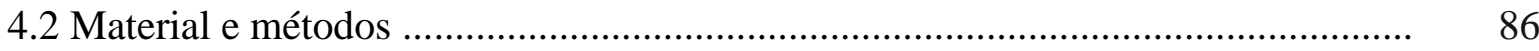

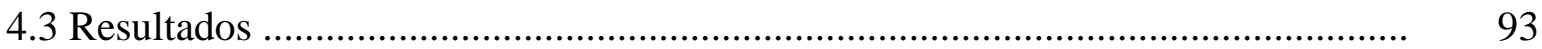

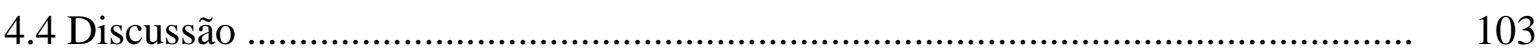

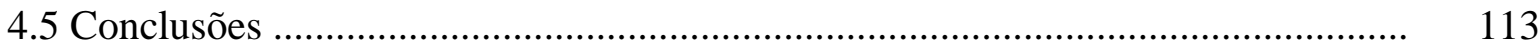

5 - REFERÊNCIAS BIBLIOGRÁFICAS …................................................... 114

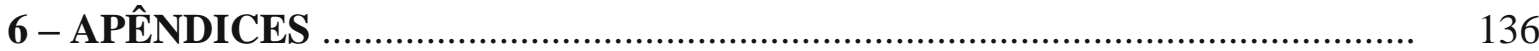




\section{LISTA DE TABELAS}

Tabela 2.1 - Dados climatológicos de Temperatura Máxima Absoluta (TM), Mínima Absoluta (TN), Umidade Relativa do Ar (UR) e Precipitação pluviométrica total anual (PP) na Reserva Cerrado da Embrapa Cerrados, em Planaltina (DF), de 1988 a 1994 e em 2012

Tabela 2.2 - Número de indivíduos, famílias, gêneros e espécies em duas áreas de Cerrado sentido restrito com diferentes históricos de fogo, em 7 ocasiões de 1988 a 2012, onde: A1 = Área 1, com aplicação de queimadas em 1988, 1990 e 1992, e proteção do fogo de 1995 a 2012; A2 = Área 2, protegida contra o fogo de 1988 a julho de 1994, e de 1995 a 2012.

Tabela 2.3 - Densidade $\left(\right.$ ind.ha $\left.{ }^{-1}\right)$ e área basal $\left(\mathrm{m}^{2} \cdot \mathrm{ha}^{-1}\right)$ em duas áreas com diferentes históricos de fogo, em um Cerrado sentido restrito, em Planaltina (DF), em sete ocasiões de monitoramento de 1988 a 2012, sendo: Área 1= com queimadas bienais em 1988, 1990 e 1992, e exclusão do fogo de 1995 a 2012; Área 2= protegida da ação do fogo de 1988 a julho de 1994, e de 1995 a 2012

Tabela 2.4 - Área basal/parcela $\left(\mathrm{m}^{2} . \mathrm{ha}^{-1}\right)$ em duas áreas com diferentes históricos de fogo, em Cerrado sentido restrito, em Planaltina (DF), em 6 ocasiões do monitoramento, onde: Área 1 = com queimadas aplicadas em agosto de 1988, 1990 e 1992, e proteção do fogo de 1995 a 2012; Área 2 = protegida do fogo de 1988 a julho de 1994, e de 1995 a 2012

Tabela 2.5 - Média (g. $\mathrm{kg}^{-1}$ ) e desvio padrão, entre parênteses, dos resultados da análise granulométrica em diferentes profundidades, em duas áreas (Área $1 \mathrm{e}$ Área 2) com diferentes históricos de fogo, em Cerrado sentido restrito, em Planaltina (DF), em 2013

Tabela 2.6 - Resultados da análise química em duas áreas (Área 1, Área 2), com diferentes históricos de fogo, em Cerrado sentido restrito em Planaltina (DF), em diferentes profundidades, em 2013

Tabela 3.1 - Características da vegetação arbóreo-arbustiva de Cerrado sentido restrito em duas áreas (Área 1, Área 2), com diferentes históricos de fogo, no período de 1991-1994, onde: Área 1, com queimadas bienais em 1988, 1990 e 1992; Área 2, protegida contra o fogo de 1988 a julho de 1994.

Tabela 3.2 - Parâmetros de dinâmica da vegetação arbóreo-arbustiva de Cerrado sentido restrito, em duas áreas (Área 1, Área 2), com diferentes históricos de fogo, no período de 1991 a 1994, sendo: Área 1, com queimadas bienais em 1988, 1990 e 1992; e Área 2, protegida contra a ação do fogo de 1988 a julho de 1994

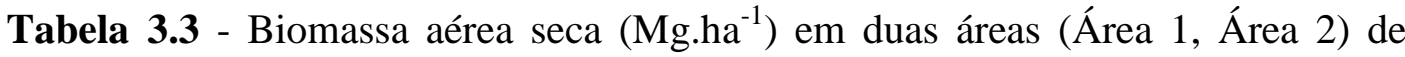
Cerrado sentido restrito, com diferentes históricos de fogo, em 6 ocasiões, onde: Área 1, com aplicação de queimadas bienais em 1988, 1990 e 1992, e proteção contra o fogo de 1995 a 2012; Área 2, protegida da ação do fogo no período de 1988 a julho de 1994 , e de 1995 a 2012 
Tabela 3.4 - Número de indivíduos com rebrotas, por espécie, em duas áreas de Cerrado sentido restrito, com diferentes históricos de queimadas, sendo: Área 1, com aplicação de queimadas bienais em 1988, 1990 e 1992; Área 2, com proteção do fogo de 1988 a julho de 1994.

Tabela 3.5 - Lista de espécies arbóreo-arbustivas de Cerrado sentido restrito utilizadas nas análises de formação de grupos funcionais em duas áreas (Área $1 \mathrm{e}$ Área 2), em dois anos do monitoramento (1994 e 2012), com respectivos atributos de classificação, de acordo com a numeração da literatura mencionada acima e observações de campo.

Tabela 4.1 - Dados climatológicos de Temperatura Máxima Absoluta (TM), Mínima Absoluta (TN), Umidade Relativa do Ar (UR) e Precipitação pluviométrica total anual (PP) na Reserva Cerrado da Embrapa Cerrados, em Planaltina (DF), de 1988 a 1994 e em 2012

Tabela 4.2 - Número de famílias, gêneros e espécies, em duas áreas de Cerrado sentido restrito, com diferentes históricos de fogo, em Planaltina (DF), em 8 ocasiões de amostragem, onde: 1=1988, 2=1989, 3=1990, 4=1991, 5=1992, 6=1993, 7=1994, 8=2012; Área 1 = com queimadas bienais em 1988, 1990 e 1992, e proteção do fogo de 1995 a 2012; Área 2 = protegida da ação do fogo de 1988 a 1994 (julho), e de 1995 a 2012

\section{LISTA DE FIGURAS}

Figura 2.1 - Mapa do Distrito Federal destacando a área da Reserva Cerrado da Embrapa Cerrados, em Planaltina (DF), em vermelho. (Fonte: modificado de Aquino et al., 2009)

Figura 2.2 - Esquema do posicionamento das transecções em duas áreas de Cerrado sentido restrito na Reserva Cerrado da Embrapa Cerrados, em Planaltina (DF), sendo: Área 1 (transecções A e B), com aplicação de queimadas bienais em agosto de 1988, 1990, e 1992, e proteção do fogo de 1995 a 2012; e Área 2 (transecções C e D), protegida contra a ação do fogo de 1988 a julho de 1994, e de

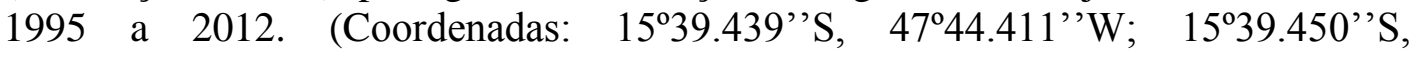
$47^{\circ} 44.406^{\prime \prime} \mathrm{W}, 15^{\circ} 39.368^{\prime}$ 'S, $\left.47^{\circ} 44.271^{\prime \prime} \mathrm{W} ; 5^{\circ} 39.377^{\prime \prime} \mathrm{S}, 47^{\circ} 44.265^{\prime \prime} \mathrm{W}\right)$

Figura 2.3 - Linha representativa indicando sete ocasiões de monitoramento (1988, 1990, 1991, 1992, 1993, 1994, 2012), o levantamento dos dados, a aplicação de queimadas controladas, e a ocorrência de fogo acidental, em duas áreas de Cerrado sentido restrito, na Reserva Cerrado da Embrapa Cerrados, em Planaltina (DF), sendo: $\boldsymbol{\uparrow}$ = aplicação de queimada controlada no mês de agosto na Área 1 ; $\uparrow=$ ocorrência de fogo acidental no mês agosto nas duas áreas (Área 1, Área 2); $\bigcirc=$ levantamento dos dados em junho-julho nas duas áreas (Área 1, Área 2); $\bigcirc=$ levantamento dos dados em setembro nas duas áreas (Área 1, Área 2). 
Figura 2.4 - Perfil de diversidade no período de 1988 a 1994 e em 2012, em Cerrado sentido restrito em Planaltina (DF), na Área 1, com três queimadas bienais de 1988 a 1992, e com exclusão do fogo de 1995 a 2012.

Figura 2.5 - Perfil de diversidade no período de 1988 a 1994, e em 2012, em Cerrado sentido restrito em Planaltina (DF), na Área 2, com proteção contra a ação do fogo de 1988 a julho de 1994, e de 1995 a 2012.

Figura 2.6 - Dendrograma de similaridade pelo método UPGMA, de acordo o índice de Jaccard, em duas áreas de Cerrado sentido restrito, com diferentes históricos de fogo, de 1988 a 2012. Divisão em 3 grupos: $\mathrm{A}=$ Área 1, com aplicação de queimadas bienais em 1988, 1990 e 1992; B = Área 2, protegida da ação do fogo de 1988 a julho de 1994; C = Área 1 e Área 2, protegidas contra a ação do fogo de 1995 a 2012. Correlação Cofenética= 0,9807. Onde: A1 = Área 1; $\mathrm{A} 2$ = Área 2 .

Figura 2.7 - Dendrograma de similaridade pelo método UPGMA, de acordo com a abundância das espécies, pelo índice de Bray Curtis, em duas áreas de Cerrado sentido restrito com diferentes históricos de fogo, de 1988 a 2012. Divisão em 3 grupos: A = Área 1, com queimadas bienais em 1988, 1990 e 1992; B = Área 1 e Área 2, protegidas contra a ação do fogo de 1995 a 2012; C= Área 2, protegida contra a ação do fogo de 1988 a julho de 1994. Correlação Cofenética= 0,9305. Onde: $\mathrm{A} 1$ = Área $1 ; \mathrm{A} 2$ = Área 2.

Figura 2.8 - Distribuição dos indivíduos arbóreo-arbustivos vivos em classes de altura, em seis ocasiões do monitoramento (1988 a 1994), em duas áreas de Cerrado sentido restrito com diferentes históricos de fogo, sendo: A = Área 1; B= Área 2. Obs.: foram incluídos indivíduos que tiveram mortalidade aérea e rebrota.

Figura 2.9 - Distribuição dos indivíduos arbóreo-arbustivos vivos em classes de altura, em duas ocasiões do monitoramento (1994 e 2012), em duas áreas de Cerrado sentido restrito com diferentes históricos de fogo, sendo: $\mathrm{A}=$ Área $1 ; \mathrm{B}=$ Área 2. Obs.: foram incluídos indivíduos que tiveram mortalidade aérea e rebrota....

Figura 2.10 - Distribuição dos indivíduos arbóreo-arbustivos vivos em classes de diâmetro, em cinco ocasiões do monitoramento (1990 a 1994), em duas áreas de Cerrado sentido restrito com diferentes históricos de fogo, sendo: $\mathrm{A}=$ Área $1 ; \mathrm{B}=$ Área 2. Obs.: foram incluídos indivíduos que tiveram mortalidade aérea e rebrota....

Figura 2.11 - Distribuição dos indivíduos arbóreo-arbustivos vivos em classes de diâmetro, em duas ocasiões do monitoramento (1994 e 2012), em duas áreas de Cerrado sentido restrito com diferentes históricos de fogo, sendo: $\mathrm{A}=$ Área 1; $\mathrm{B}=$ Área 2. Obs.: foram incluídos indivíduos que tiveram mortalidade aérea e rebrota....

Figura 3.1 - Esquema do posicionamento das transecções em duas áreas de Cerrado sentido restrito na Reserva Cerrado da Embrapa Cerrados, em Planaltina (DF), sendo: Área 1 (transecções A e B), com aplicação de queimadas bienais em agosto de 1988, 1990, e 1992, e proteção do fogo de 1995 a 2012; e Área 2 (transecções C e D), protegida contra a ação do fogo de 1988 a julho de 1994, e de

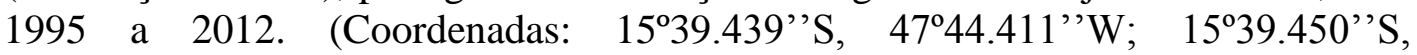


Figura 3.2 - Linha representativa indicando sete ocasiões de monitoramento (1988, 1990, 1991, 1992, 1993, 1994, 2012), o levantamento dos dados, a aplicação de queimadas controladas, e a ocorrência de fogo acidental, em duas áreas de Cerrado sentido restrito, na Reserva Cerrado da Embrapa Cerrados, em Planaltina (DF), sendo: 1 = aplicação de queimada controlada no mês de agosto na Área $1 ;$ † = ocorrência de fogo acidental no mês agosto nas duas áreas (Área 1, Área 2); $\bigcirc=$ levantamento dos dados em junho-julho nas duas áreas (Área 1, Área 2); $\bigcirc=$ levantamento dos dados em setembro nas duas áreas (Área 1, Área 2)......................

Figura 3.3 - Dendrograma de similaridade pelo método UPGMA, utilizando o índice de Jaccard, mostrando a formação de grupos funcionais para espécies arbóreo-arbustivas de Cerrado sentido restrito em 1994 na Área 1, com queimadas bienais em agosto de 1988, 1990 e 1992. Correlação Cofenética = 0,86.

Figura 3.4 - Dendrograma de similaridade pelo método UPGMA, utilizando o índice de Jaccard, mostrando a formação de grupos funcionais para espécies arbóreo-arbustivas de Cerrado sentido restrito em 1994 na Área 2, protegida contra o fogo no período de 1988 a julho de 1994. Correlação Cofenética= 0,87.

Figura 3.5 - Dendrograma de similaridade pelo método UPGMA, utilizando o índice de Jaccard, mostrando a formação de grupos funcionais para espécies arbóreo-arbustivas de Cerrado sentido restrito em 2012 na Área 1, com queimadas bienais em agosto de 1988, 1990 e 1992, fogo acidental em agosto de 1994, e com exclusão do fogo de 1995 a 2012. Correlação Cofenética $=0,84$.

Figura 3.6 - Dendrograma de similaridade pelo método UPGMA, utilizando o índice de Jaccard, mostrando a formação de grupos funcionais para espécies arbóreo-arbustivas de Cerrado sentido restrito em 2012, na Área 2, protegida contra o fogo no período de 1988 a julho de 1994, fogo acidental em agosto de 1994, e com exclusão do fogo de 1995 a 2012. Correlação Cofenética $=0,87$.

Figura 4.1 - Mapa do Distrito Federal destacando a área da Reserva Cerrado da Embrapa Cerrados, em Planaltina (DF), em vermelho. (Fonte: modificado de Aquino et al., 2009).

Figura 4.2 - Representação esquemática do método de interseção na linha, demonstrando como a unidade amostral é demarcada (a), e vista superior das espécies (Fonte: modificado de Munhoz e Araújo (2011).

Figura 4.3 - Esquema do posicionamento das transecções em duas áreas de Cerrado sentido restrito na Reserva Cerrado da Embrapa Cerrados, em Planaltina (DF), sendo: Área 1 = transecções A e B, com aplicação de queimadas bienais em 1988, 1990 e 1992, e proteção do fogo de 1995 a 2012; Área 2 = transecções C e D, com proteção contra o fogo de 1988 a julho de 1994, e de 1995 a 2012. (Coordenadas:

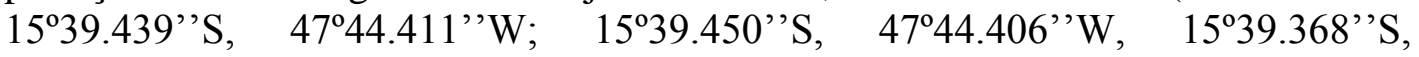
$47^{\circ} 44.271^{\prime \prime} \mathrm{W} ; 15^{\circ} 39.377^{\prime}$ 'S, $\left.47^{\circ} 44.265^{\prime \prime} \mathrm{W}\right)$. 
Figura 4.4 - Linha representativa indicando oito ocasiões do monitoramento (1988, 1989, 1990, 1991, 1992, 1993, 1994, 2012), o levantamento dos dados, a aplicação de queimadas controladas, e a ocorrência de fogo acidental, em duas áreas de Cerrado sentido restrito, na Reserva Cerrado da Embrapa Cerrados, em Planaltina (DF), sendo: $\uparrow$ aplicação de queimada controlada no mês de agosto, na Área 1; $\uparrow$ = fogo acidental no mês agosto, nas duas áreas (Área 1, Área 2); $\bigcirc=$ levantamento dos dados em junho-julho, nas duas áreas (Área 1, Área 2); $\mathrm{O}=$ levantamento dos dados em agosto, nas duas áreas (Área 1, Área 2).

Figura 4.5 - Curva espécie-área das espécies do componente herbáceo de um Cerrado sentido restrito na Reserva Cerrado da Embrapa Cerrados, em Planaltina (DF), em 1988, na Área 1. A curva central representa o número de espécies estimadas; as curvas pontilhadas representam o desvio padrão.

Figura 4.6 - Curva espécie-área das espécies do componente herbáceo de um Cerrado sentido restrito na Reserva Cerrado da Embrapa Cerrados, em Planaltina (DF), em 1988, na Área 2. A curva central representa o número de espécies estimadas; as curvas pontilhadas representam o desvio padrão.

Figura 4.7 - Porcentagem de espécies de acordo com a forma de vida em duas áreas de Cerrado sentido restrito com diferentes históricos de fogo, em oito ocasiões, onde: A= Área 1, com queimadas bienais em 1988, 1990 e 1992, e proteção do fogo de 1995 a 2012; B= Área 2, com proteção contra a ação do fogo de 1988 a julho de 1994, e de 1995 a 2012, e o levantamento dos dados, em 1994, antes do fogo acidental que atingiu as duas áreas em agosto.

Figura 4.8 - Famílias com maior número de espécies do estrato herbáceo, em duas áreas de Cerrado sentido restrito, com diferentes históricos de fogo, em oito ocasiões do levantamento florístico, sendo: A= Área 1, com queimadas bienais em 1988, 1990 e 1992, e proteção do fogo de 1995 a 2012; B= Área 2, com proteção contra a ação do fogo de 1988 a julho de 1994, e de 1995 a 2012, e o levantamento dos dados, em 1994, antes do fogo acidental que atingiu as duas áreas em agosto.

Figura 4.9 - Dendrograma de similaridade pelo método UPGMA, de acordo o índice de Jaccard, em duas áreas de Cerrado sentido restrito, em Planaltina (DF). Divisão em 3 grupos, sendo A = Área 1, de 1990 a 1994; B= Área 2, de 1990 a 1994; e C = Área 1 e Área 2, em 1989. Em 1988 (Área 1 e Área 2) e em 2012 (Área 1 e Área 2) não houve formação de grupos. Correlação cofenética $=0,94$. Obs.: Área1 = com queimadas bienais em 1988, 1990, 1992, proteção do fogo de 1995 a 2012; Área2= com proteção contra a ação do fogo de 1988 a julho de 1994, e de 1995 a 2012, e o levantamento dos dados, em 1994, antes do fogo acidental que atingiu as duas áreas em agosto.

Figura 4.10 - Perfil de diversidade, utilizando a série exponencial de Rényi, das espécies do componente herbáceo de um Cerrado sentido-restrito em duas áreas, com diferentes históricos de fogo, na Reserva da Embrapa Cerrados, em Planaltina (DF), de 1988 a 2012, sendo: A = Área 1, com queimadas bienais em 1988, 1990, 1992, e proteção do fogo de 1995 a 2012; B= Área 2, protegida contra a ação do fogo de 1988 a julho de 1994, e de 1995 a 2012, e o levantamento dos dados, em 
Figura 4.11 - Variação da Frequência Relativa (\%) das dez espécies com maiores valores em um Cerrado sentido restrito, em Planaltina-DF, na Área 1 em 1988, comparado aos valores registrados de 1989 a 1994.

Figura 4.12 - Variação da Frequência Relativa (\%) das dez espécies com maiores valores em um Cerrado sentido restrito, em Planaltina (DF), na Área 2 em 1988, comparado aos valores registrados de 1989 a 1994.

Figura 4.13 - Frequência relativa (\%) do componente herbáceo, de acordo com o hábito, em duas em duas áreas de Cerrado sentido, com diferentes históricos de fogo, em oito ocasiões do levantamento florístico; sendo: $A=$ Área 1, com queimadas bienais em 1988, 1990 e 1992, e proteção do fogo de 1995 a 2012; B= Área 2, protegida contra a ação do fogo de 1988 a julho de 1994, e de 1995 a 2012, e o levantamento dos dados, em 1994, antes do fogo acidental que atingiu as duas áreas em agosto. 


\section{1- INTRODUÇÃO GERAL}

O Cerrado possui uma das floras mais ricas das savanas do mundo (FELFILI; FELFILI, 2001; SILVA; BATES, 2002; SILVA et al., 2006). Com um total de 11.242 espécies (MENDONÇA et al. 2008) e maior proporção de herbáceas do que arbóreas, possui maior área ocupada por formações savânicas e campestres em relação às florestais (BATALHA; MANTOVANI, 2001; MENDONÇA et al., 2001; MENDONÇA et al., 2008). A diversidade de solo e de clima no bioma reflete em elevada heterogeneidade ambiental, que é considerada um dos principais fatores que atuam na estrutura e na manutenção da composição florística da vegetação (OLIVEIRA FILHO et al., 1998; RODRIGUES et al., 2003; FELFILI et al., 2008; LOPES et al., 2009). A elevada heterogeneidade florística também tem sido mencionada em vários trabalhos que conotaram a existência de um padrão de distribuição das espécies em mosaico, com uma combinação de menos de 100 espécies por área estudada, onde muitas espécies ocorrem em apenas um local e a maioria é pouco abundante ou rara (FELFILI; SILVA JR., 1993, FELFILI; FELFILI, 2001; BAUDUINO et al., 2005; FELFILI et al., 2008).

As pressões antrópicas cada vez mais intensas causam danos significativos e ameaçam as áreas remanescentes do bioma (PINHEIRO; DURIGAN, 2009). Com cerca de $46 \%$ da cobertura original do Cerrado devastada, principalmente, pelo uso da terra com pastagem plantada, agricultura anual e perene (BRASIL, 2015), as mudanças ocorridas neste bioma trouxeram danos ambientais como a fragmentação de habitats, empobrecimento da biodiversidade, invasão de espécies exóticas, erosão dos solos, poluição de aquíferos, degradação de ecossistemas, mudanças nos regimes de queimadas, desequilíbrio no ciclo do carbono e, provavelmente, alterações climáticas regionais (HOFFMANN; JACKSON, 2000; KLINK; MACHADO, 2005). A intensa fragmentação transformou a vegetação do Cerrado em manchas cercadas por pastos e agricultura que favorecem a criação de bordas, a invasão por gramíneas (PIVELLO et al. 1999; SIQUEIRA; DURIGAN, 2007; REYS et al., 2013) e a maior incidência de queimadas (HOFFMANN; MOREIRA, 2002; WALTER; RIBEIRO, 2010). No Cerrado sentido restrito alguns fatores relacionados às condições edáficas e hídricas, profundidade dos solos, frequência de queimadas e ações antrópicas influenciam na estrutura da vegetação e na variação florística entre as áreas (WALTER; RIBEIRO, 2010).

O fogo é considerado um dos fatores determinantes da vegetação do Cerrado (FELFILI et al., 2000; MIRANDA et al., 2010), pode ter origem natural ou antrópica, e 
tem o ser humano como principal agente causador dos incêndios na região, desde longo tempo (COUTINHO, 1990; MIRANDA et al., 2010). Geralmente, os incêndios naturais são provocados por raios, que são menos intensos, e ocorrem na estação chuvosa (MEDEIROS; FIEDLER, 2004), com frequência variando de 1 a mais de 9 anos (MIRANDA et al., 2010). Já as queimadas para manejo da terra aumentaram nas últimas décadas, sendo feitas na estação seca e em intervalos menores, de 1 a 4 anos (COUTINHO, 1990; MEDEIROS; FIEDLER, 2004; MIRANDA et al., 2010).

O fogo causa danos que modificam a florística, a estrutura (FELFILI et al., 2000; MEDEIROS; MIRANDA, 2005; LIBANO; FELFILI, 2006) e a dinâmica da vegetação (HOFFMANN; MOREIRA, 2002; RIBEIRO et al., 2012). Monitoramentos ao longo do tempo têm evidenciado que a vegetação do Cerrado é resiliente ao fogo (FELFILI et al., 2000; ROITMAN et al., 2008) e responde de formas diferentes à eliminação ou intensificação deste distúrbio (LIBANO; FELFILI, 2006; ALMEIDA et al., 2014). A incidência de fogo no Cerrado pode excluir algumas espécies e favorecer outras mais resistentes (MOREIRA, 2000; LIBANO; FELFILI, 2006; SILVA et al., 2011). Além de reduzir a diversidade, a frequência, a densidade (FIEDLER et al., 2004) e o recrutamento de plântulas e indivíduos jovens de espécies lenhosas (HENRIQUES; HAY, 2002), pode favorecer a colonização do estrato herbáceo (MOREIRA, 2000), modificando a composição florística (SILVA; NOGUEIRA, 1999; LOIOLA et al., 2010; SILVA et al., 2011). E com isso, a reintrodução do fogo em áreas protegidas pode promover a redução da densidade de árvores e arbustos e do tamanho médio das plantas (HOFFMANN; MOREIRA, 2002), e levar a uma progressiva simplificação na florística e estrutura da comunidade ao longo do tempo, tornando a fisionomia gradualmente mais aberta (LIBANO; FELFILI, 2006; LOPES et al., 2009).

Os impactos do fogo na vegetação dependem de fatores como o tipo, o regime de queima, o comportamento do fogo (MIRANDA et al., 2010) e a época (SATO et al., 2010). A intensidade do fogo pode variar conforme a quantidade de combustível acumulado na superfície do solo, a produção primária da camada rasteira e a quantidade de serapilheira produzida por arbustos e árvores (ONIGEMO et al., 2003). No Cerrado, as plantas podem responder de diferentes formas aos incêndios (MOREIRA, 2000), sendo que algumas espécies, tanto herbáceas quanto lenhosas, possuem estratégias de adaptação tornando-as mais resistentes. São exemplos dessas estratégias (COUTINHO, 1990; MEDEIROS; MIRANDA, 2008): a suberização do tronco e ramos, permitindo isolamento térmico dos tecidos internos; a proteção das gemas apicais pelos catáfilos; a presença de 
órgãos subterrâneos (bulbos, ramos subterrâneos, rizomas e xilopódio) (COUTINHO, 1990); os frutos com capacidade de proteção das sementes (CIRNE; MIRANDA, 2008); e a capacidade de rebrota da copa, rizomas, caule, raiz e outras estruturas subterrâneas (COUTINHO, 1990; BOND, MIDGLEY, 2001). Assim, queimadas frequentes podem favorecer espécies com algumas dessas características e eliminar espécies sensíveis ao fogo (MEDEIROS; MIRANDA, 2005; SILVA et al., 2011).

A exclusão do fogo, por outro lado, favorece a camada lenhosa, dando condições para espécies sensíveis se desenvolverem (FELFILI et al., 2000; SILVA et al., 2011), diminui a mortalidade e rotatividade de plantas e eleva as taxas de recrutamento (HENRIQUES; HAY, 2002; ROITMAN et al., 2008), com a regeneração de espécies lenhosas e incrementos em densidade e área basal (FELFILI et al., 2000; MEDEIROS; MIRANDA, 2008), e consequentemente inibição do crescimento do estrato herbáceo (GARDNER, 2006), ocasionando a redução na riqueza de espécies neste estrato (MUNHOZ; FELFILI, 2006; MEDEIROS; FIEDLER, 2011). Assim, com a exclusão, as mudanças na composição e densidade arbórea da vegetação podem permitir a evolução sucessional de fisionomias mais abertas em fisionomias mais fechadas (COUTINHO, 1990; FELFILI et al., 2000; HENRIQUES; HAY, 2002; HENRIQUES, 2005; LOPES et al., 2009; PINHEIRO; DURIGAN, 2009).

O conhecimento da florística e da estrutura é fundamental para avaliar os impactos decorrentes de atividades antrópicas, planejar a criação de unidades de conservação e para a elaboração de técnicas de manejo e conservação (FELFILI; SILVA JR., 2001; CHAVES et al., 2013). Vários estudos no Bioma Cerrado têm dado ênfase à florística e à estrutura das comunidades (FONSECA; SILVA JR., 2004; HENRIQUES, 2004; SOLORZANO et al., 2012), bem como às queimadas e suas consequências (FIEDLER et al., 2004; LIBANO; FELFILI, 2006; LOPES et al., 2009; RIBEIRO et al., 2012). No entanto, monitoramentos de longo prazo são essenciais para a obtenção de informações importantes em ecologia, mudanças ambientais, gestão de recursos naturais e conservação da biodiversidade (LINDENMAYER et al., 2012), bem como para ampliar o conhecimento e a utilização de espécies nestas áreas (AQUINO et al., 2007a,b; MEWS et al., 2011a,b).

A abordagem funcional permite auxiliar na compreensão do funcionamento e manutenção dos processos ecológicos das comunidades (PETCHEY; GASTON 2006; DENG et al., 2008; CIANCIARUSO et al., 2009). Comunidades com alta diversidade funcional devem operar de forma mais eficiente, pois maior diversidade funcional implica que uma maior amplitude de recursos está sendo mais bem utilizada (TILMAN, 2001; 
SOBRAL; CIANCIARUSO, 2012). As alterações nos grupos funcionais, geralmente, estão relacionadas às variações em certas condições ambientais, como solo, clima, intensidade e frequência de distúrbios (MULLER et al., 2007; SANSEVERO, 2013). Desta forma, o fogo pode agir como um filtro ambiental e selecionar espécies com capacidade de sobreviver e tolerar as condições abióticas derivadas deste distúrbio (CIANCIARUSO et al., 2009; SILVA et al., 2011), e com isso, as queimadas frequentes podem reduzir a diversidade funcional de comunidades do Cerrado (CIANCIARUSO et al., 2010; SILVA et al., 2011).

Nesse contexto, o estudo teve como questão principal de pesquisa: $\mathrm{O}$ fogo altera a florística, a estrutura e a dinâmica das comunidades arbóreo-arbustivas e herbáceas, em um período de 24 anos de monitoramento? Desta forma, o trabalho teve como objetivos monitorar e analisar a composição florística, a estrutura, a dinâmica, a capacidade de reprodução vegetativa, por meio de rebrotas basais e subterrâneas, e ainda a variação na biomassa e a formação de grupos funcionais no estrato arbóreo-arbustivo em áreas com diferentes históricos de queimadas, durante período de queimadas prescritas, e após 18 anos de proteção contra o fogo. Com relação ao estrato herbáceo, o estudo teve como objetivos analisar e comparar a composição florística, riqueza e diversidade, bem como a estrutura da vegetação, em uma área com ocorrência de queimadas bienais e em uma área protegida contra o fogo, no período de 1988 a 1994, e após 18 anos sem ocorrência deste distúrbio, em 2012.

O trabalho teve início em 1988, com a marcação de parcelas e transectos e início do monitoramento, em uma área pertencente à Reserva Cerrado da Embrapa Cerrados, em Planaltina, Distrito Federal. Uma área passou por queimadas bienais, aplicadas em agosto de 1988, 1990 e 1992, e por um fogo acidental em agosto de 1994. A outra área foi protegida contra o fogo de 1988 à julho de 1994, porém o fogo acidental também atingiu esta área em agosto de 1994. A partir de setembro de 1994, as áreas foram protegidas contra a ação do fogo até 2012, mas, esporadicamente, foi observada a presença de gado bovino no local dos experimentos.

A tese foi estruturada em capítulos. O Capítulo 1 apresenta a introdução geral. No Capítulo 2 foram feitas análises e comparações da composição florística, riqueza e diversidade, bem como as mudanças na estrutura da vegetação arbóreo-arbustiva em área com ocorrência de queimadas bienais e em área protegida contra o fogo, no período de 1988 à julho de 1994, e nas duas áreas, após 18 anos sem ocorrência deste distúrbio, em 2012. Parte-se da hipótese de que áreas com distintos históricos de fogo, em um período de 
seis anos, apresentam diferenças na riqueza, diversidade e estrutura da comunidade arbóreo-arbustiva; a proteção contra o fogo, por 18 anos, favorece o aumento da riqueza e da diversidade da comunidade arbóreo-arbustiva; a proteção contra o fogo, por 18 anos, favorece o aumento da densidade e área basal, e a similaridade florística entre áreas com diferentes históricos de fogo, confirmando resistência e resiliência da comunidade arbóreoarbustiva.

No Capítulo 3 foi feita a avaliação da dinâmica da comunidade arbóreo-arbustiva na área com queimadas bienais e na área protegida contra o fogo, no período de 1990 a 1994, antes do fogo acidental que atingiu as duas áreas. Neste capítulo também foram avaliadas as mudanças da biomassa aérea estimada na área com queimadas bienais e na área protegida do fogo, no período de 1990 a 1994, antes do fogo acidental que atingiu as duas áreas em agosto de 1994, e em 2012. A capacidade de rebrotar diante de queimadas bienais e a formação de grupos funcionais, de acordo com características relacionadas com o distúrbio fogo, foram investigadas entre espécies arbóreo-arbustivas presentes nas duas áreas. Parte-se das seguintes hipóteses: a incidência de queimadas bienais altera a dinâmica da comunidade arbóreo-arbustiva, com aumento na mortalidade e redução no recrutamento; a incidência de queimadas bienais diminui a biomassa aérea e a proteção contra o fogo, por 18 anos, aumenta a biomassa aérea, nas duas áreas; as queimadas bienais aumentam o número de espécies com reprodução vegetativa, com estímulo da formação de rebrotas basais e subterrâneas; a incidência de queimadas modifica os atributos de grupos funcionais de plantas lenhosas.

No Capítulo 4 foram realizadas comparações da composição florística, riqueza, diversidade e da estrutura da vegetação do estrato herbáceo, na área com queimadas bienais e na área protegida contra o fogo, no período de 1988 a 1994, antes do fogo acidental que atingiu as duas áreas em agosto, e depois, com 18 anos de exclusão deste distúrbio nas duas áreas, em 2012. Parte-se das seguintes hipóteses: a incidência de queimadas bienais, em um período de seis anos, favorece o aumento da riqueza e da diversidade, e altera a estrutura da comunidade do estrato herbáceo; a proteção de duas áreas, com diferentes históricos de fogo, por 18 anos, diminui a riqueza e a diversidade da vegetação do estrato herbáceo; e, a proteção da área contra a ação do fogo, por 18 anos, favorece a similaridade florística da camada herbácea entre áreas com diferentes históricos de fogo. 


\section{2 - MUDANÇAS PÓS-FOGO NA FLORÍSTICA E ESTRUTURA DA VEGETAÇÃO ARBÓREO-ARBUSTIVA EM UM FRAGMENTO DE CERRADO SENTIDO RESTRITO NO DISTRITO FEDERAL}

\section{RESUMO}

O monitoramento da vegetação arbóreo-arbustiva foi realizado em parcelas permanentes, em duas áreas de um fragmento de Cerrado sentido restrito em Planaltina (DF), em sete ocasiões de 1988 a 2012. Em uma área, chamada Área 1, foram aplicadas queimadas bienais, em agosto de 1988, 1990 e 1992; a outra área, chamada Área 2, foi protegida do fogo até julho de 1994, antes do fogo acidental que atingiu as duas áreas em agosto deste mesmo ano. As duas áreas foram protegidas da ação do fogo de 1995 a 2012. Nos monitoramentos, em junho-julho, antes das queimadas, foram medidas a circunferência, a $30 \mathrm{~cm}$ do solo, e a altura de todos os indivíduos arbóreo-arbustivos que atingiam 1 metro ou mais; em 1988 mediu-se a altura apenas. A riqueza foi comparada entre as duas áreas, nas diferentes ocasiões do monitoramento. A diversidade de espécies foi analisada por meio dos perfis de diversidade, e a similaridade florística pelo método UPGMA. Foram avaliados os parâmetros de densidade, frequência, dominância e Índice de Valor de Importância (IVI), em todas ocasiões. O fogo não influenciou a riqueza de espécies nas duas áreas, em todo período. Foi registrado um total de 82 espécies nas duas áreas durante todo o período de estudo, sendo que, na Área 1, foram 74 espécies, em 35 famílias; na Área 2, 73 espécies, em 34 famílias. No período de 1988 a 1994, as duas áreas apresentaram diferenças na diversidade e na similaridade florística. Após 18 anos de exclusão, as duas áreas mostraram similaridade florística, porém, diferenças na diversidade, com maior diversidade na Área 1. A comunidade arbóreo-arbustiva se mostrou resistente e resiliente ao fogo. A incidência de queimadas bienais reduziu a densidade e a área basal, no entanto, a exclusão do fogo por 18 anos favoreceu o aumento da densidade e da área basal nas duas áreas. As distribuições dos indivíduos vivos em classes de altura e de diâmetro não diferiram significativamente, nas duas áreas, e em todo período do estudo, mas o fogo afetou, principalmente, os indivíduos nas menores classes de altura e de diâmetro.

Palavras-chave: queimadas, riqueza, diversidade, similaridade, fitossociologia 


\subsection{INTRODUÇÃO}

O Cerrado vem passando por mudanças de origem antrópica associadas ao fogo, desmatamento e invasão de espécies exóticas (HENRIQUES; HAY, 2002). O fogo é um distúrbio comum que pode ter causas naturais ou antrópicas. Os incêndios naturais provocados por raios, geralmente, são menos intensos e ocorrem na estação chuvosa (MEDEIROS; FIEDLER, 2004), com uma frequência que pode variar de 1 a mais de 9 anos (MIRANDA et al., 2010). Portanto, o ser humano tem sido considerado o principal agente causador de incêndios na região do Cerrado (COUTINHO, 1990), com a queima de áreas abertas por pecuaristas, na época seca para melhorar o pasto; as derrubadas e queimadas para a abertura de novas áreas para a agricultura; o controle de arbustos nas pastagens; descuidos no manejo do fogo e a queda de balões, como exemplos (COUTINHO, 1990). Algumas dessas atividades humanas aumentaram a frequência do fogo no Cerrado (HOFFMANN; MOREIRA, 2002; WALTER; RIBEIRO, 2010), e, nas últimas décadas, as queimadas passaram a ser feitas durante a estação seca, em intervalos de 1 a 4 anos (COUTINHO, 1990; MEDEIROS; FIEDLER, 2004; MIRANDA et al., 2010).

O fogo, considerado um dos fatores determinantes da vegetação do Cerrado (FELFILI et al., 2000; MIRANDA, et al., 2010), provoca danos que modificam a florística, a estrutura (FELFILI et al., 2000; MEDEIROS; MIRANDA, 2005; LIBANO; FELFILI, 2006; NEGABAS; GAMBIZA, 2007) e a dinâmica da vegetação (HOFFMANN; MOREIRA, 2002; RIBEIRO et al., 2012). Portanto, é capaz de afetar a sobrevivência, o crescimento, o estabelecimento de plântulas e indivíduos jovens, a reprodução sexual e vegetativa, com implicações na dinâmica de populações e consequentemente de comunidades (HOFFMANN, 1996, 1999; HOFFMANN; MOREIRA, 2002). Pode ainda, reduzir a biomassa vegetal e a serapilheira, alterar os fluxos de energia, nutrientes e água (MEDINA; SILVA, 1990; MEDEIROS; MIRANDA, 2005) e criar habitats favoráveis à invasão de espécies exóticas (MILBERG et al., 1999; SILVA et al. 2011).

Monitoramentos ao longo do tempo têm demonstrado que a vegetação do Cerrado é resiliente ao fogo (FELFILI et al., 2000; ROITMAN et al., 2008) e responde de formas diferentes à eliminação ou à intensificação deste distúrbio (LIBANO; FELFILI, 2006; ALMEIDA et al., 2014). As plantas lenhosas diferem quanto à tolerância ao fogo e à capacidade de recuperação (HOFFMANN; MOREIRA, 2002; CIRNE; MIRANDA, 2008). A incidência de fogo no Cerrado pode excluir algumas espécies, favorecendo outras mais 
resistentes a ele (MOREIRA, 2000; LIBANO; FELFILI, 2006; SILVA et al., 2011), reduzir a diversidade, a frequência e a densidade de espécies lenhosas, aumentar o entouceiramento (FIEDLER et al., 2004), reduzir o recrutamento de plântulas e indivíduos jovens levando a uma interrupção ou estabilização do desenvolvimento da vegetação (HENRIQUES; HAY, 2002).

Após o distúrbio fogo, pode haver uma fase de imigração de espécies, com crescimento no número de indivíduos e na área basal, sendo seguida de uma fase com equilíbrio nas taxas de imigração (recrutamento) e extinção (mortalidade) (HENRIQUES, 2005). A reintrodução do fogo em áreas protegidas pode causar redução na densidade de árvores e arbustos e no tamanho médio das plantas (HOFFMANN; MOREIRA, 2002), levando a uma progressiva simplificação na florística e estrutura da comunidade ao longo do tempo, tornando a fisionomia gradualmente mais aberta (LIBANO; FELFILI, 2006; LOPES et al., 2009). Como exemplo, em área protegida do fogo em Cerrado, no Distrito Federal, encontraram-se plantas mais altas, enquanto que em área queimada o número de plantas nas classes de tamanho menores foi maior (MOREIRA, 2000).

A exclusão do fogo favorece a camada lenhosa, dando condições para espécies sensíveis ao fogo se desenvolverem (FELFILI et al., 2000; SILVA et al., 2011), diminui a mortalidade e rotatividade de plantas, e eleva as taxas de recrutamento (HENRIQUES; HAY, 2002; ROITMAN et al., 2008), com a regeneração de espécies lenhosas e incrementos em densidade e área basal (FELFILI et al., 2000; MEDEIROS; MIRANDA, 2008). Em monitoramento da vegetação de um Cerrado sentido restrito no Distrito Federal, ao longo de 18 anos, após exclusão do fogo, Libano e Felfili (2006) observaram que a riqueza florística e a diversidade da área sofreram pequenas modificações entre os levantamentos, mas a área se manteve com características originais, sugerindo ser relativamente estável quanto ao regime do distúrbio fogo ocorrido. $\mathrm{O}$ aumento do período de exclusão possibilitou o ingresso de novas espécies e o retorno de outras que haviam desaparecido no local do estudo. Cabe ressaltar que, com a exclusão, as mudanças na composição e densidade arbórea da vegetação podem, ainda, permitir a evolução sucessional de fisionomias mais abertas em fisionomias mais fechadas (COUTINHO, 1990; FELFILI et al., 2000; HENRIQUES; HAY, 2002; HENRIQUES, 2005; LOPES et al., 2009; PINHEIRO; DURIGAN, 2009).

A maioria das pesquisas no Bioma Cerrado tem dado ênfase à florística e à estrutura das comunidades (FONSECA; SILVA JR., 2004; HENRIQUES, 2004; SOLORZANO et al., 2012). As queimadas e suas consequências também têm sido 
amplamente estudadas (MOREIRA, 2000; SATO, 2003; FIEDLER et al., 2004; MEDEIROS; MIRANDA, 2005; LIBANO; FELFILI, 2006; LOPES et al., 2009; RIBEIRO et al., 2012). No entanto, ainda há necessidade de avaliar as mudanças da vegetação ao longo do tempo para entender os processos e mecanismos que mantêm a comunidade (AQUINO et al. 2007b; PINHEIRO; DURIGAN, 2009; CARMO et al., 2011; MEWS et al., 2011a). Portanto, pesquisas relacionadas às mudanças temporais e, após histórico de ocorrência de fogo, na florística e estrutura de comunidade arbórea, arbustiva e herbácea do Cerrado são essenciais para o conhecimento da diversidade, estabilidade e dinâmica da comunidade, além de possibilitar o estabelecimento de estratégias para conservação, uso sustentável e recuperação do bioma. As informações e o conhecimento sobre a influência das queimadas ao longo do tempo para a camada lenhosa no Cerrado sentido restrito ainda são necessárias.

Assim, este capítulo teve como objetivos analisar e comparar a composição florística, riqueza e diversidade, bem como analisar as mudanças na estrutura da vegetação arbóreo-arbustiva de um fragmento de Cerrado sentido restrito, em uma área com ocorrência de queimadas bienais e em uma área protegida contra o fogo, no período de 1988 a 1994, antes do fogo acidental que atingiu as duas áreas em 1994, e após 18 anos sem ocorrência deste distúrbio, nas duas áreas, em 2012. Com isso, procurou-se responder às seguintes perguntas: 1) Áreas com distintos históricos de fogo, em um período de seis anos, apresentam diferenças na riqueza, diversidade e estrutura da comunidade arbóreoarbustiva? 2) A proteção contra o fogo, por 18 anos, favorece o aumento da riqueza e da diversidade da comunidade arbóreo-arbustiva? 3) A proteção contra o fogo, por 18 anos, favorece o aumento da densidade e área basal, e a similaridade florística entre áreas com diferentes históricos de fogo, confirmando resistência e resiliência da comunidade arbóreoarbustiva?

\subsection{MATERIAL E MÉTODOS}

\subsection{1 Área de estudo}

O trabalho foi desenvolvido em um fragmento de Cerrado sentido restrito na Reserva Cerrado (Figura 2.1) pertencente ao grupo de Reservas Ecológicas da Embrapa Cerrados, a Nordeste do Distrito Federal, na região administrativa de Planaltina (DF), nas coordenadas $15^{\circ} 38^{\prime} \mathrm{S}$ e $47^{\circ} 43^{\prime} \mathrm{W}$, datum horizontal Córrego Alegre, MG (PARRON et al., 1998). A área da reserva faz parte da Chapada da Contagem, que é a unidade 
geomorfológica mais elevada do Distrito Federal (PARRON et al., 1998). O solo é do tipo Latossolo Vermelho (SANTOS et al., 2013), textura muito argilosa, relevo plano a suave ondulado, fase cerrado (Typic haplustox), desenvolvido a partir da decomposição da cobertura detrítico-laterítica de caráter argiloso do Terciário (SPERA et al., 2000). O clima é caracterizado como Aw na classificação de Köppen, com uma estação seca de 5 meses, precipitação média anual de $1.577 \mathrm{~mm}$, temperatura média anual de $20,4{ }^{\circ} \mathrm{C}$, temperatura máxima média de $26,6^{\circ} \mathrm{C}$, e mínima média de $15,8^{\circ} \mathrm{C}$, com altitude de $1.100 \mathrm{~m}$ (SPERA et al., 2000). Na Tabela 2.1 são apresentados os dados de temperatura, umidade relativa e precipitação pluviométrica, de acordo com a estação climatológica da Embrapa Cerrados para o período de estudo de 1988 a 1994 e 2012.

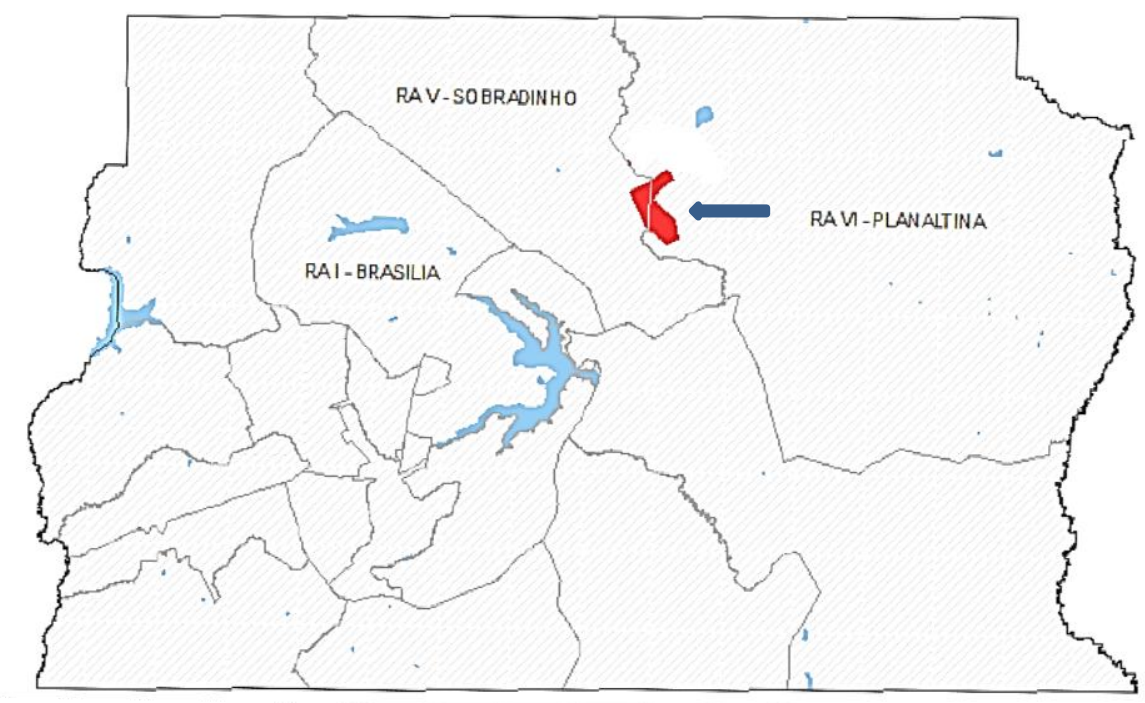

Figura 2.1 - Mapa do Distrito Federal destacando a área da Reserva Cerrado da Embrapa Cerrados, em Planaltina (DF), em vermelho. (Fonte: modificado de Aquino et al., 2009).

Tabela 2.1 - Dados climatológicos de Temperatura Máxima Absoluta (TM), Mínima Absoluta (TN), Umidade Relativa do Ar (UR) e Precipitação pluviométrica total anual (PP) na Reserva Cerrado da Embrapa Cerrados, em Planaltina (DF), de 1988 a 1994 e em 2012.

Parâmetro Ano

\begin{tabular}{lcccccccc} 
& 1988 & 1989 & 1990 & 1991 & 1992 & 1993 & 1994 & 2012 \\
\hline TM $\left({ }^{\circ} \mathrm{C}\right)$ & 26,6 & 26,4 & 26,9 & 26,2 & 25,7 & 27,2 & 27,1 & 27,3 \\
TN $\left({ }^{\circ} \mathrm{C}\right)$ & 16,1 & 16,2 & 16,2 & 15,8 & 15,7 & 16,0 & 16,4 & 16,1 \\
UR $\left({ }^{\%}\right)$ & 69,1 & 71,3 & 68,5 & 69,1 & 71,5 & 67,3 & 66,3 & 47,7 \\
PP $(\mathrm{mm})$ & 1818,6 & 1788,6 & 1348,1 & 1843,8 & 2220 & 1175 & 1568,3 & 1288,4 \\
\hline
\end{tabular}

Fonte: Estação climatológica da Embrapa Cerrados, Planaltina, DF. 


\subsubsection{Histórico da área}

No ano de 1987, no mês de maio, um grupo de pesquisadores da Embrapa Cerrados, da Universidade de Los Andes - ULA (Mérida-Venezuela) e da Harvard University (EUA) iniciou uma série discussões sobre o projeto, o local e a metodologia a serem estabelecidos, e ainda neste ano o projeto foi oficializado na Embrapa Cerrados e na Embrapa Sede com o nome "Ecologia das Comunidades Vegetais de Cerrado Frente a Perturbações e Estresses" - 026870022, para ser iniciado em 1988, sob a coordenação do Dr. José Carlos Sousa Silva. As atividades de campo começaram em maio de 1988, quando houve implantação do projeto com a demarcação da área dos experimentos. As tomadas de dados foram iniciadas em junho e julho de 1988, com a participação dos pesquisadores Dr. José Carlos Sousa Silva, Dra. Maria Lúcia Meirelles e Dr. Carlos Augusto Klink. Em 2012, o levantamento dos dados ficou sob coordenação de Mary Naves da Silva Rios e José Carlos Sousa Silva.

O local do estudo tem um histórico de queimadas, onde, de acordo com informações de funcionários da Embrapa Cerrados, não houve registros de queimadas de 1979 a 1988, havendo proteção contra o fogo. Em agosto de 1994, no entanto, houve fogo acidental em toda área dos experimentos, porém, de 1995 até 2012 o local foi protegido contra o fogo, não havendo ocorrência de queimadas.

O entorno da área da Reserva Cerrado da Embrapa Cerrados era formado, principalmente, por chácaras até 1994, porém, em anos mais recentes, foi observado aumento do desmatamento com a criação de condomínios particulares e residenciais, assentamentos rurais e novas estradas. A área da fazenda experimental, além da reserva, inclui outros projetos de pesquisa com pastagem, gado bovino, culturas perenes, dentre outros. Com isso, esporadicamente, foi observada a presença de gado no local dos experimentos.

\subsubsection{Amostragem e coleta dos dados}

O estudo foi conduzido em uma área com cerca de 2,5 ha $\left(15^{\circ} 39.439^{\prime \prime} \mathrm{S}\right.$,

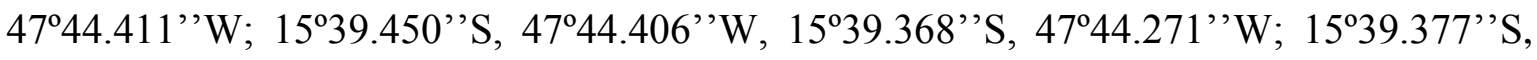
$\left.47^{\circ} 44.265^{\prime} \mathrm{W}\right)$ que foi dividida em duas áreas de cerca de 1,25 ha, com diferentes históricos de fogo (Figura 2.2). Em uma das áreas, chamada neste estudo de Área 1, foram 
aplicadas queimadas bienais; na outra área, chamada de Área 2, houve proteção contra o fogo até julho de 1994, pois em agosto deste ano um fogo acidental atingiu as duas áreas.

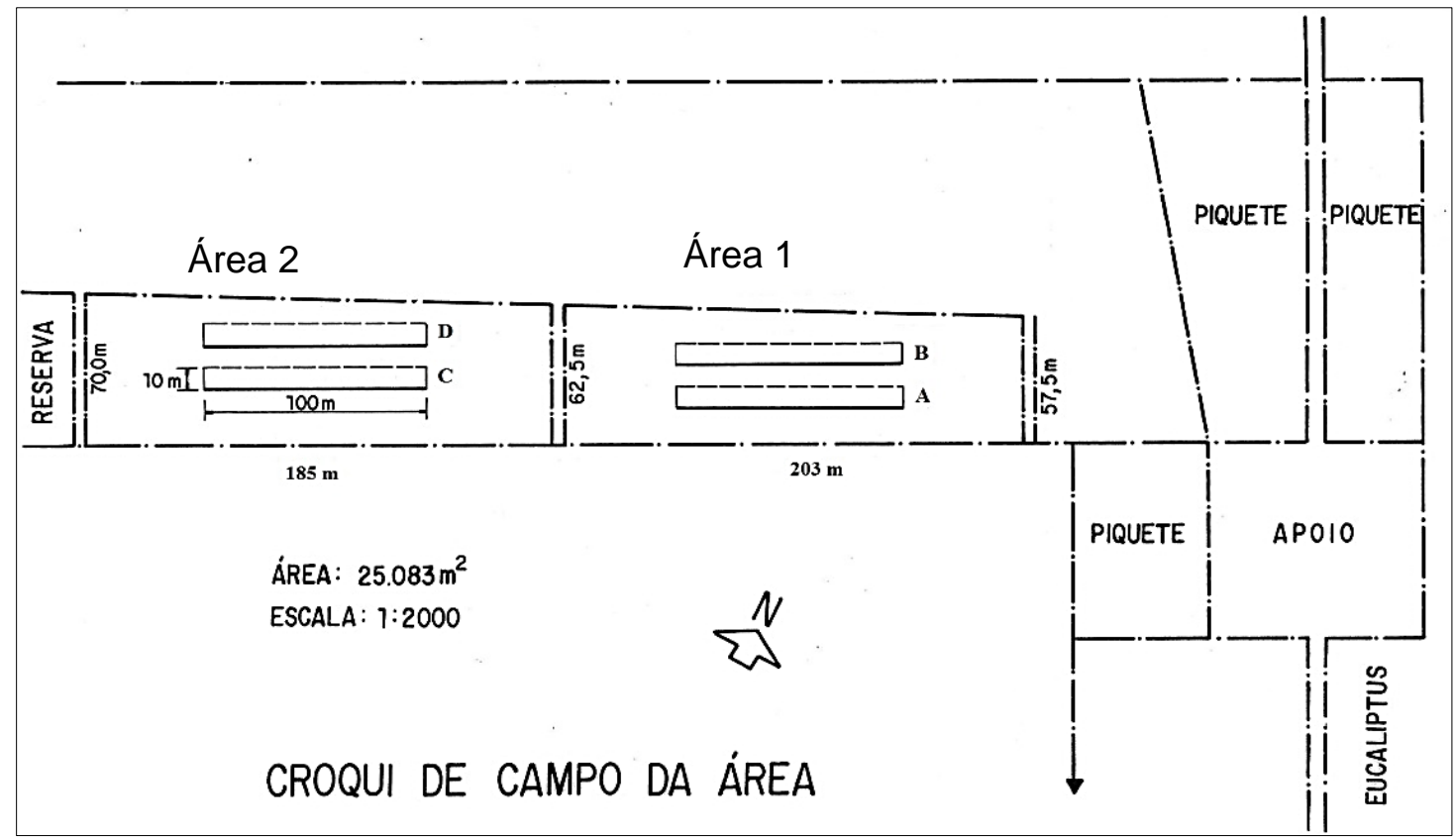

Figura 2.2 - Esquema do posicionamento das transecções em duas áreas de Cerrado sentido restrito na Reserva Cerrado da Embrapa Cerrados, em Planaltina (DF), sendo: Área 1 (transecções A e B), com aplicação de queimadas bienais em agosto de 1988, 1990, e 1992, e proteção do fogo de 1995 a 2012; e Área 2 (transecções C e D), protegida contra a ação do fogo de 1988 a julho de 1994, e de 1995 a 2012. (Coordenadas: 15³9.439' 'S,

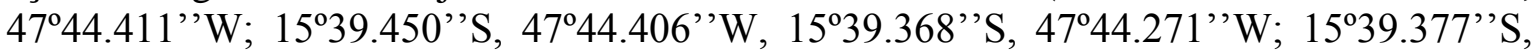
$\left.47^{\circ} 44.265^{\prime \prime} \mathrm{W}\right)$.

Em cada área foram demarcadas duas transecções com 100 metros de comprimento e 10 metros de largura, e distanciadas 10 metros entre si, totalizando quatro transecções (A, B, C, D) (Figura 2.2). A amostragem da vegetação arbóreo-arbustiva foi feita utilizando-se o método de parcela (MORO; MARTINS, 2011). As parcelas foram demarcadas em maio de 1988 ao longo das transecções nas duas áreas (Área 1, Área 2). Em 1988 foram demarcadas parcelas de 20mx10m, porém em 1990 as parcelas foram remarcadas no mesmo local com medidas de 10mx10m, para facilitar os trabalhos de campo. Assim, a partir de 1990 o monitoramento foi feito em parcelas de $10 \mathrm{mx} 10 \mathrm{~m}\left(100 \mathrm{~m}^{2}\right)$ nas duas áreas, totalizando 20 parcelas e uma área de amostragem de 0,2 hectares em cada área.

$\mathrm{Na}$ Área 1 (transecções A e B) houve a aplicação de queimadas bienais, que foram adotadas por serem mais comuns na região do Cerrado (COUTINHO, 1982, 1990; SATO, 2003). As queimadas controladas foram aplicadas em 1988, 1990 e 1992, sempre no mês de agosto, por ser a época de ocorrência mais frequente de queimadas na região de Brasília (COUTINHO et al., 1982; SATO, 1996). Em 1994 não houve a aplicação da queimada 
controlada, pois houve a ocorrência de fogo acidental também no mês de agosto (Figura 2.3).

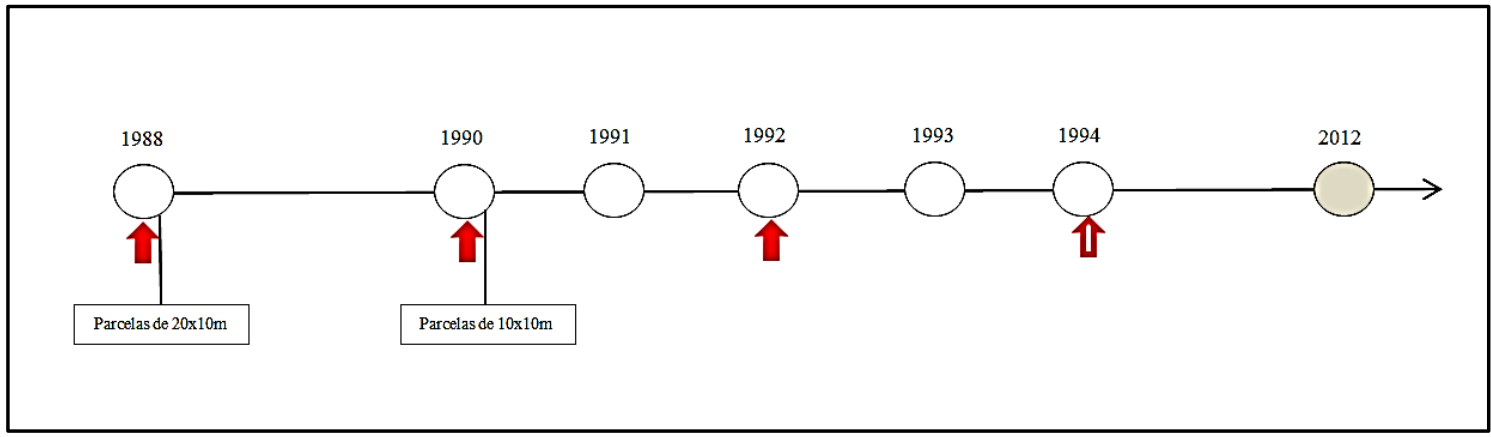

Figura 2.3 - Linha representativa indicando sete ocasiões de monitoramento (1988, 1990, 1991, 1992, 1993, 1994, 2012), o levantamento dos dados, a aplicação de queimadas controladas, e a ocorrência de fogo acidental, em duas áreas de Cerrado sentido restrito, na Reserva Cerrado da Embrapa Cerrados, em Planaltina (DF), sendo: $\boldsymbol{\uparrow}=$ aplicação de queimada controlada no mês de agosto na Área 1 ; $\Uparrow=$ ocorrência de fogo acidental no mês agosto nas duas áreas (Área 1, Área 2); $\bigcirc=$ levantamento dos dados em junho-julho nas duas áreas (Área 1, Área 2); $\bigcirc=$ levantamento dos dados em setembro nas duas áreas (Área 1, Área 2).

O fogo foi aplicado na Área 1, sempre pela manhã, por uma equipe previamente preparada de funcionários da Embrapa Cerrados. Antes de cada queimada foram construídos aceiros em volta desta área. A Área 2 (transecções C e D), foi protegida contra a ação do fogo até julho de 1994, pois em agosto de 1994 o fogo acidental também atingiu esta área (Figura 2.3). As duas áreas foram protegidas contra a ação do fogo de 1995 à 2012. O monitoramento da vegetação teve início em 1988 e foi realizado sempre antes do fogo, em sete ocasiões (1988, 1990, 1991, 1992, 1993, 1994, 2012). De 1988 a 1994 foram feitos levantamentos nos meses de junho-julho, e em 2012, em setembro, ainda no período seco.

Nos levantamentos, todas as espécies arbóreo-arbustivas, que atingiam o critério de inclusão de um metro ou mais de altura (MUELLER-DOMBOIS; ELLEMBERG, 1974) foram numeradas com placas de alumínio e mensuradas. Anotaram-se, para cada indivíduo, a altura e a circunferência, bem como o nome das espécies ocorrentes em cada parcela. Também foram incluídos os indivíduos mortos que "estavam em pé" e as espécies da família Arecaceae e de Vellozia sp que atingiam a altura mínima de um metro. Em 2012, nem todas as placas antigas (colocadas de 1988 a 1994) permaneciam nos indivíduos. Desta forma, mantiveram-se as placas antigas, continuando a numeração a partir de 3000 para os indivíduos que não possuíam placas, pois em 1994 o emplacamento havia parado em número próximo de 2900. 
A altura total foi medida com o uso de uma régua graduada de três metros, sendo que as alturas acima de três metros foram estimadas visualmente, tomando como base a régua; a circunferência foi medida com fita métrica. Em 1988 foram anotados somente os dados referentes à altura dos indivíduos. Nos anos de 1990 a 1994 e em 2012 foram feitas medidas de altura e circunferência. As medidas de circunferência foram tomadas a $30 \mathrm{~cm}$ do solo, altura considerada padrão em vários estudos no Cerrado (FELFILI; SILVA JR., 1988; FELFILI et al., 2005; ALMEIDA et al., 2014). Os dados de diâmetro foram calculados posteriormente.

Quando o exemplar de uma espécie se ramificava abaixo do nível do solo e cada eixo emergia separado dos demais, cada eixo foi considerado um indivíduo distinto (MORO; MARTINS, 2011). Nos casos em que os indivíduos, dentro do critério de inclusão adotado, apresentavam bifurcações abaixo de $30 \mathrm{~cm}$, mediram-se todos os ramos e, posteriormente, foi calculado o diâmetro quadrático das ramificações, conforme sugerido por Scolforo e Thiersch (2004) pela fórmula: $d=\sqrt{\left(d_{1}\right)^{2}+\left(d_{2}\right)^{2}}$; sendo: $d=$ diâmetro quadrático; $d^{1}=$ diâmetro do ramo $1 ; d^{2}=$ diâmetro do ramo 2 .

Durante o monitoramento da vegetação arbórea de 1990 a 1994, nas duas áreas, foram incluídos os indivíduos novos que alcançavam a altura de um metro, sendo, assim, considerados recrutas. Estes também foram medidos quanto à altura e circunferência e marcados com placas de alumínio na sequência da numeração do primeiro inventário em 1988. Também foram anotadas, ao longo do tempo (1990 a 1994), as plantas que morriam e aquelas que rebrotavam. Considerou-se rebrota os indivíduos que tiveram morte aérea, onde a copa e caule foram queimados, e que apresentavam brotações na parte basal ou subterrânea das plantas. Os indivíduos com mortalidade aérea ou destruição total do caule, quando não apresentavam rebrota, foram considerados mortos.

Nos levantamentos florísticos de 1988 até 1994 foram feitas coletas de material botânico fértil e depósito no Herbário da Universidade de Brasília (UB), Herbário do Jardim Botânico de Brasília - Ezechias Paulo Heringer (HEPH), Herbário da Reserva Ecológica do IBGE e da Embrapa Recursos Genéticos e Biotecnologia - CENARGEN (CEN), em Brasília, Distrito Federal. As espécies férteis coletadas de 2012 a 2015 foram depositadas no Herbário da Universidade de Brasília (UB).

A caracterização do solo, nas duas áreas, para o período de 1988 e 1994, quanto às análises químicas e físicas, foi publicada nos artigos de Spera et al. (2000) e de Braga et al. (1998). Para a caracterização do solo, em 2013, seguiu-se a mesma metodologia 
empregada por estes autores. Assim, foram realizadas as seguintes análises: pH em água; teor percentual de matéria orgânica (MO) pelo método Walkey-Black; potássio (K) pelo fotômetro de chama; fósforo (P) pelo extrator Mehlich 1, e espectofotometria; Alumínio (Al) por titulometria; cálcio $(\mathrm{Ca})$ e Magnésio $(\mathrm{Mg})$ por absorção atômica. Na análise granulométrica foram obtidos os teores de areia, silte e argila, conforme Corá et al. (2009) e Dodagena et al. ( 2011).

As coletas de solo foram realizadas em outubro de 2013, em três pontos por área (Área 1, Área 2), com três repetições, e em 8 profundidades (de 0 a 15, 15 a 30, 30 a 45, 45 a 60, 60 a 75, 75 a 90, 90 a 105 e 105 a 120), totalizando 48 amostras que foram utilizadas nas análises químicas. As análises de solo foram feitas no Laboratório de Física e Mineralogia de Solos e no Laboratório de Química Analítica de Solos da Embrapa Cerrados, de acordo com o Manual da Embrapa (EMBRAPA, 1997; DODAGENA et al., 2011). Os resultados das análises químicas e físicas foram comparadas entre as duas áreas. Para a análise granulométrica foram utilizadas as amostras até $45 \mathrm{~cm}$ de profundidade; os resultados de cada profundidade entre as duas áreas ( 1 e 2) foram comparados pelo teste de t pareado (ZAR, 2009), utilizando o software Excel 2010 do Windows.

\subsubsection{Análise dos dados}

A lista de espécies foi feita de acordo com APG III - The Angiosperm Phylogeny Group (CHASE; REVEAL, 2009). As espécies foram identificadas por meio de consultas a especialistas, literatura e comparação com exsicatas de Herbários. Para a conferência dos nomes científicos foi consultada, principalmente, a Lista de Espécies da Flora do Brasil (FLORA..., 2015). A composição florística foi comparada nas diferentes ocasiões de amostragem. Para verificar se houve diferença entre a riqueza de espécies ao longo do tempo entre as duas áreas, os resultados em cada área (1 e 2) foram comparados pelo teste de t pareado (ZAR, 2009) no período de 1988 a 1994 e em 2012. A riqueza de espécies de cada área também foi comparada aos pares de anos, por meio do teste de $\chi^{2}$ (SOKAL; ROHLF, 2009) utilizando o software Excel 2010.

Para analisar se houve diferença entre o número de espécies/parcela entre as duas áreas (Área 1, Área 2), e em cada ano (de 1988 a 1994 e em 2012), os valores foram comparados por meio do teste de $\mathrm{t}$ para amostras dependentes (ZAR, 2009). Os dados foram transformados em raiz quadrada a fim de reduzir a variabilidade entre estes. Foi avaliado, primeiro, se os valores obtidos de riqueza atendiam aos pressupostos de 
normalidade e homocedasticidade. As análises foram feitas no programa PAST versão 2.15 (HAMMER et al., 2001) e no software Excel 2010 do Windows.

Para examinar a diferença no número médio de indivíduos entre as duas áreas, ao longo do tempo, os resultados de cada área (Área 1, Área 2) foram comparados pelo teste de t pareado (ZAR, 2009) no período de 1990 a 1994 e em 2012. Os resultados de 1988 não foram comparados devido às diferenças no tamanho das parcelas. $\mathrm{O}$ número total de indivíduos em cada área (1 e 2) foi comparado entre os anos (de 1988 a 1994 e em 2012), aos pares de anos, por meio do teste de $\chi^{2}$ (SOKAL; ROHLF, 2009). Para verificar se houve diferença entre o número de indivíduos/parcela entre as duas áreas (Área 1, Área 2), e em cada ano (de 1988 a 1994 e 2012), os valores foram comparados por meio do teste de t para amostras dependentes (ZAR, 2009). Os dados foram transformados em raiz quadrada a fim de reduzir a variabilidade entre estes. Avaliou-se, primeiro, se os valores obtidos de riqueza atendiam aos pressupostos de normalidade e homocedasticidade. O programa PAST versão 2.15 (HAMMER et al., 2001) e o software Excel 2010 do Windows foram empregados nas análises.

A diversidade de espécies, entre as duas áreas, foi comparada empregando Perfis de Diversidade, usando a série exponencial de Rényi (TÓTHMÉRÉSZ, 1995), no programa PAST 2.15 (HAMMER et al., 2001). Com isto foi possível observar graficamente a diversidade sob diferentes pesos dados às espécies raras (LEINSTER; COBBOLD, 2012).

A similaridade florística entre as duas áreas e ao longo do tempo de estudo foi analisada utilizando o método de Ligação Média Não Ponderada (UPGMA), que expressa por meio de um dendrograma as relações de similaridades entre as áreas. O dendrograma com base na abundância empregou o índice de Bray-Curtis e o dendrograma com base na presença e ausência das espécies empregou o índice de Jaccard (VALENTIN, 2000). O Coeficiente de correlação cofenética foi calculado, pois avalia o grau de distorção entre a matriz de similaridade e o dendrograma. Quanto mais próximo de um, menor o grau de distorção (VALENTIN, 2000). Foram construídas duas matrizes: uma com o número de indivíduos para cada espécie e ano e outra com base na presença e ausência das espécies para cada ano. As análises foram feitas no programa FITOPAC 2.1 (SHEPHERD, 2010).

$\mathrm{Na}$ descrição da comunidade arbóreo-arbustiva foram feitos cálculos dos parâmetros de Frequência, Densidade, Dominância e Índice de Valor de Importância (IVI), no programa FITOPAC 2.1 (SHEPHERD, 2010) para o período de 1990 a 1994 e 2012 , incluindo também os indivíduos que rebrotaram na base do caule ou de estruturas 
subterrâneas com altura acima de $30 \mathrm{~cm}$. Foram usadas as seguintes fórmulas (MORO; MARTINS, 2011; FREITAS; MAGALHÃES, 2012):

Frequência absoluta: $\mathrm{FA}(\mathrm{e})=100(\mathrm{Pe} / \mathrm{Pt})$. Onde: $F A e$ é a frequência absoluta de dada espécie $e ; P e$ é o número de unidades amostrais em que a espécie $e$ ocorre; $P t$ é o número total de unidades amostrais utilizadas no trabalho. Frequência relativa $(\%)$ : FRe = 100(FA(e)/Fat). Onde FAe é a frequência relativa de dada espécie; FAe é a frequência absoluta da espécie $e$; Fat é o somatório da frequência absoluta de todas as espécies.

Densidade absoluta total da comunidade: $\mathrm{DAt}=\mathrm{N} / \mathrm{A}$. Onde DAt é a densidade absoluta total da comunidade; $\mathrm{N}$ é o número total de indivíduos amostrados da comunidade; e A é a área amostrada, em hectares ou fração de hectare. Densidade absoluta de uma espécie: $\mathrm{DAe}=\mathrm{n}_{\mathrm{e}} / \mathrm{A}$. Onde DAe é a densidade absoluta de uma espécie $e ; \mathrm{n}_{\mathrm{e}}$ é o número de indivíduos amostrados da espécie $e$. Densidade relativa: $\mathrm{DRe}=100$ $\mathrm{n}_{\mathrm{e}} / \mathrm{N}$. Onde DRe é a densidade relativa de dada espécie $e ; \mathrm{n}_{\mathrm{e}}$ é o número de indivíduos amostrados da espécie $e ; \mathrm{N}$ é o número total de indivíduos amostrados da comunidade.

Dominância absoluta: $\mathrm{DoAe}=\sum \mathrm{Ge} / \mathrm{A}$. Onde DoAe é a dominância absoluta da espécie $e ; \sum \mathrm{Ge}$ é o somatório da área basal de todos os indivíduos da espécie $e$; A é a área total amostrada, em hectare. A soma das dominâncias absolutas de todas as espécies fornece a dominância absoluta total da comunidade (DoAt). Dominância relativa: DoRe $=100(\mathrm{Ge} / \mathrm{Gt})$. Onde DoRe é a Dominância relativa; Ge é a área basal da espécie e; Gt é a área basal total.

Índice de Valor de Importância (IVI): IVIe=DRe+FRe+DoRe. Onde: IVIe é o valor de importância de uma dada espécie $e$; DRe é a densidade relativa da espécie $e$; FRe é a frequência relativa da espécie $e$ e DoRe é a dominância relativa da espécie $e$.

As distribuições dos indivíduos das comunidades em classes de altura e diâmetro foram analisadas usando a equação de Sturges, proposta por Spiegel (FELFILI; REZENDE, 2003): $\mathrm{IC}=\mathrm{A} / \mathrm{NC}$ e NC $=1+3,3 \log$ (n). Sendo: $\mathrm{A}=$ amplitude (valor máximo - valor mínimo); $\mathrm{NC}=$ número de classes; $\mathrm{n}$ = número de indivíduos. Foram construídos histogramas de frequência com intervalos de classes de diâmetro de 5,3 e de altura de 1,2 para os indivíduos registrados nas duas áreas de 1988 a 2012. Em 1988 as análises foram feitas somente com dados de altura, pois, neste ano, o diâmetro não foi mensurado.

Para a elaboração dos histogramas em classes de diâmetro, nos anos que ocorreram rebrotas, também foram incluídas somente aquelas com altura maior que $30 \mathrm{~cm}$. Porém, os histogramas em classes de altura incluíram todos os indivíduos. Para analisar se a 
distribuição dos indivíduos vivos, em classes de diâmetro e altura, variou ao longo do tempo e nas duas áreas foi aplicado o teste não paramétrico de Kolmogorov-Smirnov (ZAR, 2009), a um nível de significância de 5\%, pareando as amostras a cada dois anos, utilizou-se o programa PAST 2.15 (HAMMER et al., 2001).

As mudanças estruturais na densidade, de 1988 a 2012, e de área basal, de 1990 a 2012, nas duas áreas, foram avaliadas pelo teste de $\mathrm{t}$ de Student e teste de t pareado (ZAR, 2009), no Software Excel 2010, do Windows. Os dados foram transformados em raiz quadrada a fim de reduzir a variabilidade. Avaliou-se, primeiro, se os valores atendiam aos pressupostos de normalidade e homocedasticidade.

\subsection{RESULTADOS}

\section{Florística}

Os resultados do monitoramento no período com queimadas bienais de 1988 a 1994 e em 2012 evidenciaram mudanças em relação à composição florística. O número de indivíduos vivos e de espécies variou tanto na Área 1, quanto na Área 2, nas diferentes ocasiões (Tabela 2.2; Apêndice 1). Na Área 1, o número de indivíduos foi inferior ao encontrado em 1988 em todos anos de 1990 até 1994. Já na Área 2, o número de indivíduos foi superior ao ano de 1988, em todos os anos. Na ocasião do primeiro levantamento, em 1988, antes do tratamento com fogo bienal, foram registrados 656 indivíduos na Área 1 e 509 na Área 2.

Tabela 2.2 - Número de indivíduos, famílias, gêneros e espécies em duas áreas de Cerrado sentido restrito com diferentes históricos de fogo, em 7 ocasiões de 1988 a 2012, onde: A1 = Área 1, com aplicação de queimadas em 1988, 1990 e 1992, e proteção do fogo de 1995 a 2012; A2 = Área 2, protegida contra o fogo de 1988 a julho de 1994, e de 1995 a 2012.

\begin{tabular}{|c|c|c|c|c|c|c|c|c|c|c|c|c|c|c|}
\hline \multirow[t]{2}{*}{ Parâmetros } & \multicolumn{2}{|c|}{1988} & \multicolumn{2}{|c|}{1990} & \multicolumn{2}{|c|}{1991} & \multicolumn{2}{|c|}{1992} & \multicolumn{2}{|c|}{1993} & \multicolumn{2}{|c|}{ 1994* } & \multicolumn{2}{|c|}{2012} \\
\hline & A1 & A2 & A1 & A2 & A1 & A2 & A1 & A2 & A1 & A2 & A1 & A2 & A1 & A2 \\
\hline Indivíduos & 656 & 509 & 383 & 783 & 446 & 790 & 490 & 812 & 476 & 910 & 471 & 924 & 1288 & 1206 \\
\hline Famílias & 31 & 30 & 31 & 31 & 30 & 29 & 30 & 29 & 30 & 29 & 30 & 29 & 33 & 32 \\
\hline Gêneros & 48 & 45 & 43 & 49 & 42 & 45 & 42 & 44 & 42 & 46 & 42 & 45 & 54 & 53 \\
\hline Espécies & 54 & 49 & 49 & 56 & 49 & 50 & 49 & 49 & 49 & 51 & 49 & 50 & 68 & 63 \\
\hline
\end{tabular}

*Obs.: o levantamento dos dados, em 1994, ocorreu antes do fogo acidental que atingiu as duas áreas em agosto.

O tratamento com fogo levou a uma redução no número de indivíduos após a primeira queimada, sendo que em 1990 o número de indivíduos reduziu consideravelmente 
para 383 indivíduos na Área 1; na Área 2, o número aumentou para 783. Em 1994, antes do fogo acidental que afetou as duas áreas em agosto, havia 471 na Área 1 e 924 na Área 2. Assim, após três queimadas bienais (1988 a 1992), na Área 1, o número de indivíduos vivos reduziu em 185 indivíduos (28,2\%), em comparação à 1988; na Área 2 houve aumento de 415 indivíduos $(81,5 \%)$. A proteção das duas áreas contra o fogo durante 18 anos favoreceu o aumento da abundância nas duas áreas após 1994, o número de indivíduos aumentou para 1288 na Área 1 e 1206 na Área 2 (Tabela 2.2).

Comparando o número de indivíduos total nas duas áreas em 1988, antes das queimadas, com as diferentes ocasiões do tratamento com fogo (1990 a 1994), pelo teste de $\chi^{2}$, observou-se que o fogo influenciou esta variável em todos os anos. A proteção da área também influenciou o número de indivíduos de 1994 a 2012, nas duas áreas (p <0,05). O número de indivíduos também variou nas parcelas, nas duas áreas, em todos os anos. $\mathrm{O}$ teste de $\mathrm{t}$ apontou diferenças significativas no número de indivíduos por parcela entre as duas áreas em todas as ocasiões de 1990 a 1994, durante queimadas prescritas ( $\mathrm{p}<0.05)$. Porém, no ano de 2012 não houve diferença entre o número de indivíduos por parcela entre a Área 1 e a Área 2 ( $\mathrm{p}>0,05, \mathrm{p}=0,29)$. Quando se comparou a média do número de indivíduos no período de 1990 a 1994, pelo teste de t pareado, também houve diferença significativa entre a Área 1 e a Área $2(\mathrm{p}=0,000007)$.

Quanto à riqueza foi registrado um total de 82 espécies nas duas áreas durante todo o período de estudo, sendo que na Área 1 foram 58 gêneros e 74 espécies, em 35 famílias; na Área 2 foram 58 gêneros e 73 espécies, em 34 famílias (Tabela 2.2; Apêndice 1). Na área 1, de 1988 a 1994, Fabaceae foi a família com maior abundância, e em 2012 Nyctaginaceae. Em 1988, as três famílias mais abundantes foram: Fabaceae (107), Nyctaginaceae (91) e Styracaceae (54); em 2012 Nyctaginaceae (224), Fabaceae (186) e Primulaceae (161) (Apêndice 2). Na área 2, Fabaceae foi a família mais abundante no período de 1988 a 1992; em 1993, 1994 e 2012 foi a família Primulaceae. Em 1988, as três famílias mais abundantes foram: Fabaceae (99), Primulaceae (70) e Nyctaginaceae (62); em 2012, Primulaceae (349), Fabaceae (200) e Melastomataceae (92). Fabaceae foi a família com maior número de espécies nas duas áreas, em todas as ocasiões de amostragem (1988 a 2012), variando de 9 a 14 espécies na Área 1, e de 10 a 12 espécies na Área 2. Em 1988 na Área 1, das 31 famílias, 71\% eram representadas com uma espécie apenas; em 1994, das 30 famílias, 73,33\% tinham uma espécie. Na área 2, em 1988, 67\%, das 30 famílias encontradas, tinham somente uma espécie; em 1994, 62\%, das 29 famílias, tinham uma espécie. 
O número de espécies, para cada área, não teve variação significativa no período de tratamento com fogo. No primeiro levantamento, antes das queimadas, em 1988, eram 54 espécies (31 famílias, 48 gêneros), na Área 1, e 49 espécies (30 famílias, 45 gêneros) na Área 2. Durante o período do tratamento com fogo bienal o número de famílias, gêneros e espécies variou. Após três queimadas prescritas bienais, em 1994, registraram-se 49 espécies (30 famílias, 42 gêneros), na Área 1; na Área 2 foram observadas 50 espécies (29 famílias, 45 gêneros). Em 2012, após 18 anos de proteção contra o fogo, havia 68 espécies na Área 1 (33 famílias, 54 gêneros) e 63 espécies (32 famílias, 53 gêneros) na Área 2. Analisando a riqueza de espécies em cada área e ano, aos pares, durante o período de queimadas bienais, de 1988, antes da primeira queimada, com 1990 a 1994, observou-se que o fogo não influenciou a riqueza nas duas áreas pelo teste de $\chi^{2}(\mathrm{p}<0,05)$. A proteção da área durante 18 anos também não influenciou a riqueza de espécies em 2012 pelo teste do $\chi^{2}$ (pvalor=0,72). Por outro lado, com relação ao número de espécies/parcela, o teste de t mostrou diferenças significativas (ao nível de 5\%) entre a Área 1 e a Área 2, em cada ocasião da amostragem, de 1988 a 2012 (Apêndice 3).

No período do monitoramento algumas espécies foram incluídas e outras desapareceram, não ocorrendo mais na área de estudo. Várias espécies se mantiveram na área mesmo com as queimadas bienais. Das 74 espécies que foram registradas na Área 1, durante todo o período de estudo, 45 ocorreram todos os anos e 13 apareceram somente em 2012. As espécies Salacia crassifolia, Andira humilis, Erythroxylum campestre, Symplocos rhamnifolia, Qualea multiflora e Aegiphila verticillata apareceram no primeiro ou segundo ano, e não foram mais registradas nesta área após as sucessivas queimadas, e mesmo após 18 anos da proteção, em 2012. Estas espécies desapareceram da área ou não alcançaram o critério de inclusão.

$\mathrm{Na}$ área 2, das 73 espécies, 44 ocorreram todos os anos e 14 apareceram somente no ano de 2012. As espécies Davilla elliptica, Erythroxylum campestre, Erythroxylum tortuosum e Byrsonima basiloba apareceram somente nos anos iniciais (1988 ou 1990) e depois desapareceram ou não alcançaram o critério de inclusão. Em 2012, apenas um indivíduo da família Lauraceae, de uma espécie não identificada, que não é comum no Cerrado sentido restrito, ocorreu na Área 2.

Treze espécies foram consideradas raras na Área 1, pois, em pelo menos um dos levantamentos (1988 a 2012) foram representadas por apenas um indivíduo. Como exemplo, tem-se Hancornia speciosa, Eremanthus goyazensis, Palicourea rigida e Senna rugosa. Já na Área 2, 26 foram consideradas raras, em pelo menos um dos levantamentos 
(1988 a 2012), como por exemplo, Andira vermifuga, Annona monticola, Salacia crassifolia e Davilla elliptica. Nas duas áreas, um total de 26 espécies foram raras, das quais Andira humilis, Diospyros hispida, Byrsonima coccolobifolia, Erythroxylum campestre, Brosimum gaudichaudii e Casearia sylvestris ocorreram tanto na Área 1 quanto na Área 2. Algumas espécies foram favorecidas com a proteção contra o fogo, nas duas áreas. Na Área 1, Myrsine guianensis, teve redução na sua população de 37 indivíduos em 1988 para quatro em 1990. Porém, o período de proteção contra o fogo aumentou este número para 158, em 2012. Guapira graciliflora tinha 75 indivíduos em 1988, quatro em 1990 e 180 em 2012. Protium ovatum que tinha oito indivíduos em 1988, também foi sensível às queimadas, não tendo indivíduos vivos até 1994, e foi favorecido com a proteção, tendo 31 indivíduos em 2012 (Apêndice 1). Na Área 2, Myrsine guianensis aumentou sua população ao longo do período de monitoramento passando de 70 indivíduos em 1988, para 175 em 1994 e 348 em 2012. Protium ovatum tinha 13 indivíduos em 1988, nove em 1990, e 47 em 2012. Por outro lado, Neea theifera tinha 25 indivíduos em 1990, 39 em 1994, e reduziu para dois em 2012. Aegiphila verticillata que tinha 19 indivíduos em 1988 e 26 em 1994 não teve registro em 2012.

Quanto à diversidade, o perfil de diversidade mostrou que as duas áreas (Área 1, Área 2) eram diferentes em 1988, sendo que a Área 2 apresentou maior diversidade. No período de 1990 a 1994, na Área 1, ocorreu sobreposição das curvas mostrando diversidade similar. Na área 2, também houve sobreposição das curvas de 1991 a 1994, revelando diversidade similar nestes anos. Após 18 anos sem fogo, as duas áreas também se mostraram diferentes em diversidade (Figura 2.4; Figura 2.5). Em 2012, a área com queimadas bienais (Área 1) apresentou maior diversidade que a Área 2; equabilidade menor na Área 2 (distribuição das abundâncias menos uniforme). 


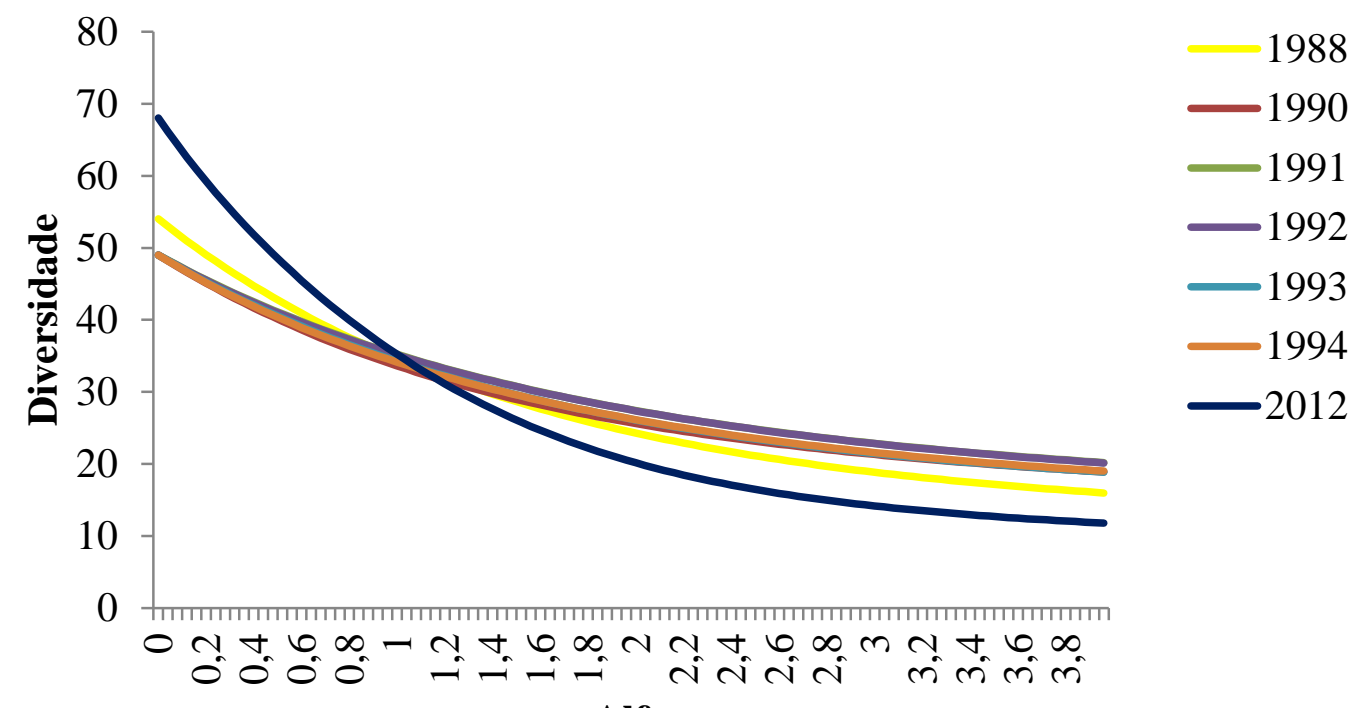

Alfa

Figura 2.4 - Perfil de diversidade no período de 1988 a 1994 e em 2012, em Cerrado sentido restrito em Planaltina (DF), na Área 1, com três queimadas bienais de 1988 a 1992, e com exclusão do fogo de 1995 a 2012.

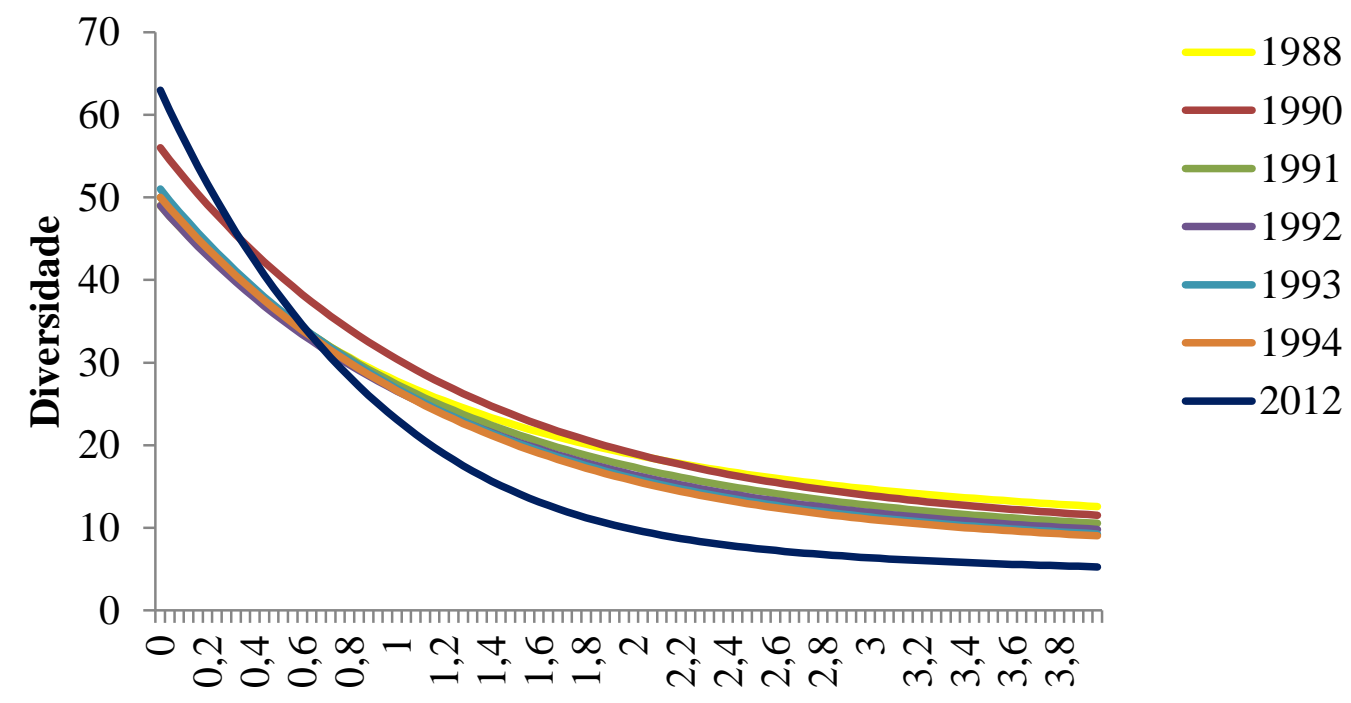

Alfa

Figura 2.5 - Perfil de diversidade no período de 1988 a 1994, e em 2012, em Cerrado sentido restrito em Planaltina (DF), na Área 2, com proteção contra a ação do fogo de 1988 a julho de 1994, e de 1995 a 2012.

A análise de agrupamento, pelo índice de Jaccard, como uma forma de mostrar diferenças entre as áreas, nos diferentes anos de monitoramento, indicou a formação de três grupos distintos, de acordo com a área. O Grupo A é formado pela Área 1, onde houve aplicação de queimadas bienais, de 1988 a 1994; o Grupo B, pela Área 2, que foi protegida do fogo de 1988 a julho de 1994; e o Grupo C, pela Área 1 e Área 2 no ano de 2012, ou seja, após 18 anos sem queimadas. O coeficiente de correlação cofenética de 0,98 é 
considerado elevado; pouco se perdeu da similaridade original com a elaboração do dendrograma (Figura 2.6).

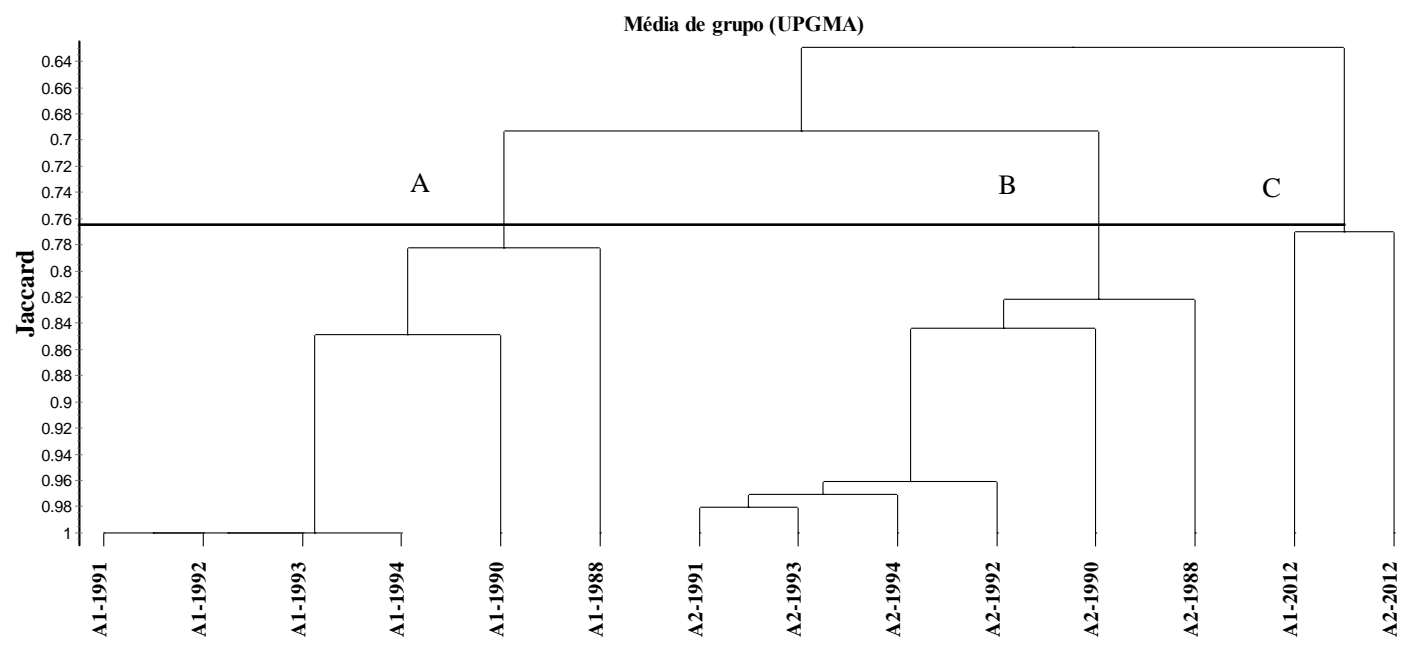

Figura 2.6 - Dendrograma de similaridade pelo método UPGMA, de acordo o índice de Jaccard, em duas áreas de Cerrado sentido restrito, com diferentes históricos de fogo, de 1988 a 2012. Divisão em 3 grupos: A = Área 1, com aplicação de queimadas bienais em 1988, 1990 e 1992; B = Área 2, protegida da ação do fogo de 1988 a julho de 1994; C = Área 1 e Área 2, protegidas contra a ação do fogo de 1995 a 2012. Correlação Cofenética= 0,9807. Onde: $\mathrm{A} 1=$ Área $1 ; \mathrm{A} 2=$ Área 2.

A análise de agrupamento usando o índice de Bray-Curtis também indicou a formação de três grupos (Figura 2.7). O Coeficiente de Correlação Cofenética é considerado alto $(0,93)$ demonstrando que pouco se perdeu da similaridade original com a elaboração do dendrograma. Os Grupos foram diferenciados pelas áreas estudadas, ou seja, área com queimada bienal, Área 1, e a Área 2. O Grupo A é formado pela Área 1 (nos anos de 1988 a 1994), quando houve aplicação de queimadas; o Grupo B pela Área 1 e Área 2, em 2012, após 18 anos sob proteção contra o fogo; e o Grupo C pela Área 2, protegida contra o fogo, nos anos de 1988 a julho de 1994. 


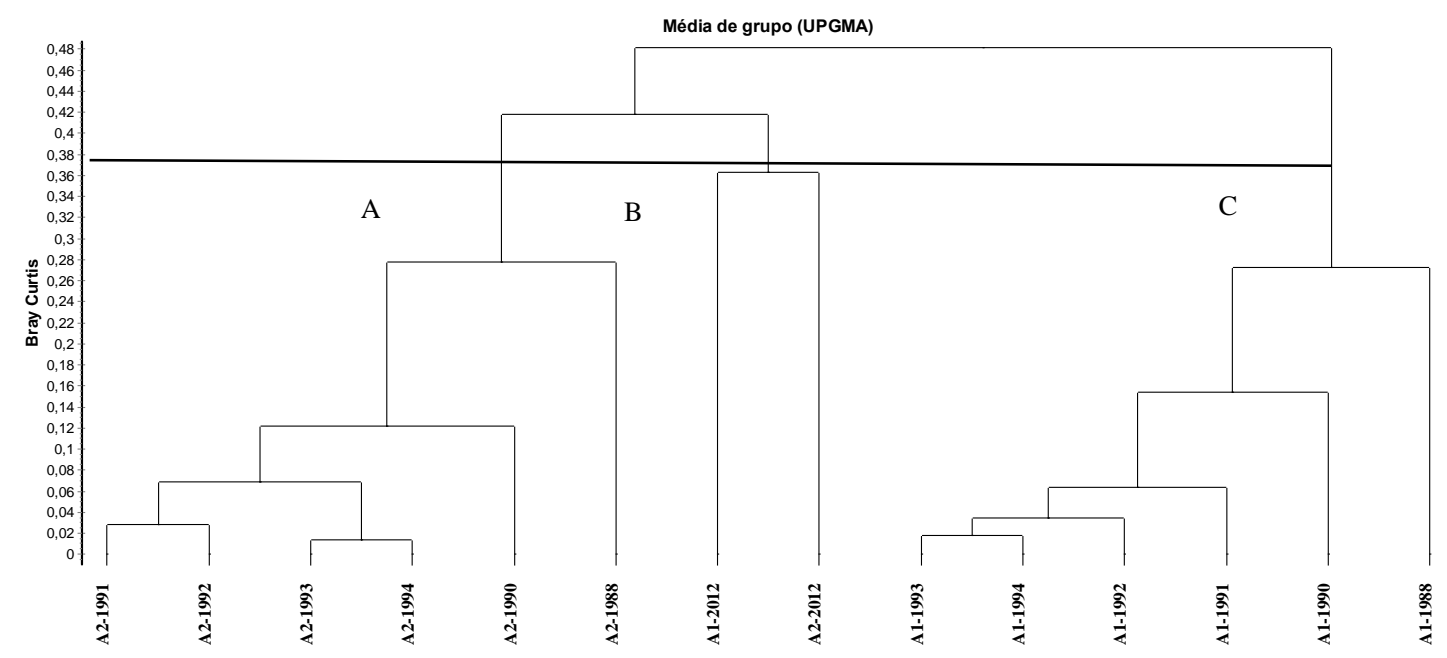

Figura 2.7 - Dendrograma de similaridade pelo método UPGMA, de acordo com a abundância das espécies, pelo índice de Bray Curtis, em duas áreas de Cerrado sentido restrito com diferentes históricos de fogo, de 1988 a 2012. Divisão em 3 grupos: A = Área 1, com queimadas bienais em 1988, 1990 e 1992; B = Área 1 e Área 2, protegidas contra a ação do fogo de 1995 a 2012; C= Área 2, protegida contra a ação do fogo de 1988 a julho de 1994. Correlação Cofenética= 0,9305. Onde: A1 = Área 1; A2 = Área 2.

\section{Estrutura da vegetação}

A densidade total estimada variou nas duas áreas, com diferenças significativas nos valores observados entre as duas áreas no período com queimadas bienais de 1988 a 1994 (p<0,05) (Tabela 2.3). Na Área 1 passou de 3280 ind.ha $^{-1}$ em 1988 para 1915 ind.ha $^{-1}$, em 1990, e em 1994 aumentou para 1950 ind.ha ${ }^{-1}$. Na Área 2, a densidade aumentou todos os anos, passando de 2545 ind.ha $^{-1}$ em 1988, para 4595 ind.ha $^{-1}$ em 1994. Em 2012 foram estimados 6440 ind.ha ${ }^{-1}$ na Área 1 e 6030 ind.ha ${ }^{-1}$ na Área 2. A densidade nas parcelas variou entre 1994 e 2012, com diferenças significativas ( $p<0,05$ ), no entanto, em 2012, não houve diferenças entre as duas áreas ( $p>0,05)$. 
Tabela 2.3 - Densidade (ind.ha $\left.{ }^{-1}\right)$ e área basal $\left(\mathrm{m}^{2} \cdot \mathrm{ha}^{-1}\right)$ em duas áreas com diferentes históricos de fogo, em um Cerrado sentido restrito, em Planaltina (DF), em sete ocasiões de monitoramento de 1988 a 2012, sendo: Área 1= com queimadas bienais em 1988, 1990 e 1992, e exclusão do fogo de 1995 a 2012; Área 2= protegida da ação do fogo de 1988 a julho de 1994, e de 1995 a 2012.

\begin{tabular}{ccccccccc}
\hline Parâmetro & Área & \multicolumn{7}{c}{ Ano } \\
\cline { 3 - 9 } & & $\mathbf{1 9 8 8}$ & $\mathbf{1 9 9 0}$ & $\mathbf{1 9 9 1}$ & $\mathbf{1 9 9 2}$ & $\mathbf{1 9 9 3}$ & $\mathbf{1 9 9 4} *$ & $\mathbf{2 0 1 2}$ \\
\hline Densidade & Área 1 & 3280 & 1915 & 2230 & 2440 & 1870 & 1950 & 6440 \\
(ind.ha $\left.^{-1}\right)$ & Área 2 & 2545 & 3915 & 3950 & 4050 & 4480 & 4595 & 6030 \\
Área basal & Área 1 & - & 8,5 & 9,1 & 9,5 & 9,8 & 9,3 & 18,8 \\
$\left(\mathrm{~m}^{2} \cdot \mathrm{ha}^{-1}\right)$ & Área 2 & - & 9,5 & 10 & 11 & 12,2 & 12 & 16,7 \\
\hline
\end{tabular}

*Obs.: o levantamento dos dados, em 1994, ocorreu antes do fogo acidental que atingiu as duas áreas em agosto.

A área basal apresentou diferentes valores na Área 1, variando de $8,48 \mathrm{~m}^{2} \cdot \mathrm{ha}^{-1} \mathrm{em}$ 1990 e 9,27 m².ha ${ }^{-1}$ em 1994, para 18,85 $\mathrm{m}^{2} \cdot \mathrm{ha}^{-1}$ em 2012 (Tabela 2.3). Na Área 2 variou de $9,54 \mathrm{~m}^{2} \cdot \mathrm{ha}^{-1}$ em 1990 e $11,99 \mathrm{~m}^{2} \cdot \mathrm{ha}^{-1}$ em 1994, para 16,69 $\mathrm{m}^{2} \cdot \mathrm{ha}^{-1}$ em 2012. O teste de $\mathrm{t}$ pareado mostrou diferenças tanto da área basal total/ha quanto da área basal média entre as duas áreas, no período de 1990 a 1994 (p=0,009).

A área basal variou nas parcelas, em todos os anos e nas duas áreas. Na Área 1, a área basal variou de 2,46 $\mathrm{m}^{2} \cdot \mathrm{ha}^{-1}$ (parcela 8, em 1990) a $16,12 \mathrm{~m}^{2} \cdot \mathrm{ha}^{-1}$ (parcela 4 , em 1992). Na área 2 variou de $3,96 \mathrm{~m}^{2} \cdot \mathrm{ha}^{-1}$ (parcela 25, em 1990) a 22,38 $\mathrm{m}^{2} \cdot \mathrm{ha}^{-1}$ (parcela 28 , em 1993). Em 2012 a área basal variou de $11,37 \mathrm{~m}^{2} \cdot \mathrm{ha}^{-1}$ (parcela 17) a 30,15 $\mathrm{m}^{2} \cdot \mathrm{ha}^{-1}$ (parcela 3), na Área 1; e de 7,78 $\mathrm{m}^{2} \cdot \mathrm{ha}^{-1}$ (parcela 29) a 28,84 $\mathrm{m}^{2} \cdot \mathrm{ha}^{-1}$ (parcela 33), na Área 2 (Tabela 2.4). O teste de $\mathrm{t}$ não mostrou diferenças significativas entre a área basal/parcela entre a Área 1 e Área 2, de 1990 a 1993, e em 2012. Porém, após três queimadas e dois anos sem queimar, em 1994 o teste apontou diferenças significativas, ao nível de significância de $5 \%(\mathrm{p}=0,04)$, entre a Área 1 e a Área 2 . O teste de $\mathrm{t}$ pareado também mostrou diferenças significativas na área basal por parcela entre o ano de 1994 e 2012 $(\mathrm{p}<0.05)$, período em que a área ficou protegida contra o fogo, tanto na Área 1 quanto na Área 2; não houve diferenças significativas entre a área basal/parcela comparando-se a Área 1 e a 2 em $2012(\mathrm{p}=0,11)$. 
Tabela 2.4 - Área basal $\left(\mathrm{m}^{2} . \mathrm{ha}^{-1}\right)$ em duas áreas com diferentes históricos de fogo, em Cerrado sentido restrito, em Planaltina (DF), em 6 ocasiões do monitoramento, onde: Área $1=$ com queimadas aplicadas em agosto de 1988, 1990 e 1992, e proteção do fogo de 1995 a 2012; Área 2 = protegida do fogo de 1988 a julho de 1994, e de 1995 a 2012.

\begin{tabular}{|c|c|c|c|c|c|c|c|}
\hline \multirow[t]{2}{*}{ Área } & \multirow[t]{2}{*}{ Parcelas } & \multicolumn{6}{|c|}{ Ano } \\
\hline & & 1990 & 1991 & 1992 & 1993 & 1994* & 2012 \\
\hline 1 & 1 & 6,8 & 6,72 & 7,63 & 8,14 & 7,36 & 14,32 \\
\hline 1 & 2 & 9,09 & 9,51 & 10,79 & 10,47 & 9,81 & 24,32 \\
\hline 1 & 3 & 12,19 & 12,25 & 13,72 & 13,38 & 12,95 & 30,15 \\
\hline 1 & 4 & 10,63 & 10,39 & 16,12 & 12,74 & 12,81 & 14,95 \\
\hline 1 & 5 & 8,5 & 9,14 & 10,66 & 10,27 & 10,13 & 16,48 \\
\hline 1 & 6 & 5,53 & 6,41 & 7,35 & 7,14 & 6,4 & 18,97 \\
\hline 1 & 7 & 13,19 & 14,07 & 9,94 & 14,7 & 14,4 & 27,02 \\
\hline 1 & 8 & 2,46 & 3,24 & 3,8 & 3,75 & 4,12 & 16,26 \\
\hline 1 & 9 & 12,51 & 13,94 & 14,03 & 15,3 & 14,62 & 15,85 \\
\hline 1 & 10 & 4,46 & 4,9 & 5,84 & 5,69 & 4,77 & 15,67 \\
\hline 1 & 11 & 8,22 & 8,82 & 10 & 12,45 & 11,91 & 21,85 \\
\hline 1 & 12 & 10,28 & 9,33 & 10,41 & 11,45 & 10,66 & 23,62 \\
\hline 1 & 13 & 4,78 & 5,87 & 6,15 & 5,53 & 5,22 & 17,59 \\
\hline 1 & 14 & 5,01 & 5,23 & 4,15 & 3,63 & 3,47 & 14,31 \\
\hline 1 & 15 & 11,36 & 12,73 & 12,78 & 12,91 & 12,63 & 18,7 \\
\hline 1 & 16 & 7,95 & 10,52 & 9,88 & 8,11 & 8,11 & 15,53 \\
\hline 1 & 17 & 6,52 & 7,31 & 7,5 & 7,59 & 6,37 & 11,37 \\
\hline 1 & 18 & 3,71 & 3,92 & 4,42 & 3,41 & 3,36 & 17,12 \\
\hline 1 & 19 & 12,54 & 13,95 & 13,37 & 15,14 & 14,51 & 21,75 \\
\hline 1 & 20 & 13,83 & 13,75 & 11,84 & 12,77 & 11,88 & 21,17 \\
\hline 2 & 21 & 6,71 & 6,15 & 6,53 & 9,12 & 8,71 & 13,66 \\
\hline 2 & 22 & 11,57 & 14,69 & 16,42 & 18,32 & 17,7 & 18,66 \\
\hline 2 & 23 & 10,76 & 11,67 & 12,71 & 13,71 & 13,16 & 18,46 \\
\hline 2 & 24 & 9,7 & 9,83 & 11,58 & 11,49 & 10,79 & 19,72 \\
\hline 2 & 25 & 3,96 & 4,84 & 5,75 & 6,93 & 6,6 & 11,96 \\
\hline 2 & 26 & 4,81 & 4,98 & 6,25 & 7,11 & 8,46 & 12,96 \\
\hline 2 & 27 & 5,15 & 5,48 & 6,19 & 7,16 & 6,82 & 15,54 \\
\hline 2 & 28 & 20,71 & 18,97 & 21,21 & 22,38 & 22,1 & 15,74 \\
\hline
\end{tabular}




\begin{tabular}{l|l|c|c|c|c|c|c}
\hline 2 & 29 & 7,49 & 7,05 & 7,24 & 8,07 & 7,42 & 7,78 \\
2 & 30 & 7,99 & 7,86 & 8,99 & 10,37 & 9,33 & 13,76 \\
2 & 31 & 7,21 & 8,28 & 9,28 & 9,93 & 9,68 & 16,91 \\
2 & 32 & 8,25 & 8,29 & 10,64 & 12,3 & 11,63 & 18,05 \\
2 & 33 & 14,6 & 14,55 & 14,63 & 16,29 & 14,71 & 28,84 \\
2 & 34 & 8,24 & 8,06 & 9,94 & 11,1 & 10,13 & 12,44 \\
2 & 35 & 16,3 & 17,87 & 18,83 & 20,57 & 20,29 & 15,36 \\
2 & 36 & 15,65 & 15,53 & 18,01 & 17,84 & 19,51 & 21,85 \\
2 & 37 & 7,36 & 8,03 & 8,51 & 10,07 & 9,66 & 13,49 \\
2 & 38 & 9,2 & 10,31 & 10,76 & 11,31 & 11,49 & 16,82 \\
2 & 39 & 7,93 & 8,65 & 9,14 & 11,22 & 10,88 & 26,06 \\
2 & 40 & 7,23 & 9,71 & 7,59 & 9,17 & 10,74 & 15,71 \\
\hline
\end{tabular}

*Obs.: o levantamento dos dados, em 1994, ocorreu antes do fogo acidental que atingiu as duas áreas em agosto.

$\mathrm{Na}$ Área 1, entre as 10 espécies com maior Índice de Valor de Importância (IVI) em 1990, nove se mantiveram durante o período de 1991 a 1994: Byrsonima verbascifolia, Dalbergia miscolobium, Guapira noxia, Ouratea hexasperma, Schefflera macrocarpa, Styrax ferrugineus, Syagrus flexuosa, Tachigali subvelutina, Vellozia squamata (Apêndice 4). Estas nove espécies tiveram variação no número de indivíduos e de IVI, mudando, assim, a posição na classificação com relação ao Índice de Valor de Importância (IVI) no período de queimadas bienais (1990 a 1994). Em 2012, destas nove espécies, três se mantiveram entre as $10 \mathrm{com}$ maior IVI: Styrax ferrugineus, Tachigali subvelutina e Vellozia squamata. Em 1990, as 10 espécies com maior IVI correspondiam a 51,7\% do IVI total; em 1994, correspondiam a 53,1\% do IVI total; em 2012, 13 espécies correspondiam a $51,1 \%$ do IVI total.

$\mathrm{Na}$ Área 1, em 1990, Vellozia squamata foi a espécie com maior IVI principalmente devido à sua área basal (dominância), seguida de Ouratea hexasperma, com menor dominância e maior densidade. De 1991 a 1994 Ouratea hexasperma teve maior IVI, devido à sua maior densidade; Vellozia squamata ficou em segunda ou terceira posição em 1991, 1993, 1994, com menor densidade e maior dominância quando comparada às outras espécies. Em 1992 Styrax ferrugineus foi a segunda espécie com maior IVI, Syagrus flexuosa a terceira e Vellozia squamata a quarta. Em 2012 Tachigali 
subvelutina que estava na oitava posição em 1990, foi a espécie com maior IVI, em razão da dominância relativa $(18,37 \%)$ elevada em relação às outras espécies. Guapira graciliflora, que estava na $35^{\text {a }}$ posição em 1990, com quatro indivíduos, passou a ser a segunda espécie mais importante, devido ao aumento na densidade relativa $(13,98 \%)$, frequência relativa $(3,58 \%)$ e dominância relativa (4,8\%). Myrsine guianensis que também era pouco abundante em 1990, com quatro indivíduos, e estava na 32a posição na classificação pelo IVI, passou a ser a terceira mais importante, também devido ao aumento na densidade relativa (12,27\%), principalmente. De 1988 para 1990 as espécies Myrsine guianensis (5,6 para 1,04 \%) e Guapira graciliflora (11,4 para 1,04 \%) mostraram redução na densidade relativa; já Vellozia squamata (de 1,98 para 3,9\%), Syagrus flexuosa (de 4,8 para 8,9\%) e Ouratea hexasperma (5,03 para 8,09\%) apresentaram aumento.

$\mathrm{Na}$ Área 2, das 10 espécies com maior IVI em 1990, sete se mantiveram no período de 1991 a 1994: Myrsine guianensis, Dalbergia miscolobium, Guapira noxia, Styrax ferrugineus, Ouratea hexasperma, Guapira graciliflora e Byrsonima verbascifolia (Apêndice 5). Estas sete espécies tiveram variação no número de indivíduos e de IVI, mudando, assim, a posição na classificação com relação ao Índice de Valor de Importância (IVI) no período de 1990 a 1994. Em 2012, destas sete, seis permaneceram entre as 10 espécies com maior IVI: Myrsine guianensis, Dalbergia miscolobium, Guapira noxia, Styrax ferrugineus, Ouratea hexasperma, Guapira graciliflora. Em 1990 e 1991 Dalbergia miscolobium apresentou maior IVI; já em 1992, 1993, 1994 e 2012 Myrsine guianensis foi a espécie com maior IVI. Em todos os anos as 10 espécies com maior IVI representavam cerca de 50\% do IVI total. Em 1990 representavam 53,5\%; em 1994, 53,3\%; em 2012 $51,4 \%$.

Nas duas áreas, cinco espécies ficaram entre as 10 de maior IVI, de 1990 a 1994: Dalbergia miscolobium, Guapira noxia, Styrax ferrugineus, Ouratea hexasperma e Byrsonima verbascifolia. Na Área 2, as espécies Dalbergia miscolobium, Myrsine guianensis e Guapira noxia se mantiveram entre as três de maior IVI, de 1990 a 2012. Dalbergia miscolobium se manteve na primeira posição até 1991, devido à maior dominância relativa (13,58 e 14,27 \%) em relação às outras espécies. De 1992 a 1994, Myrsine guianensis se manteve na primeira posição em razão da elevada densidade relativa $(17,65 ; 18,86 ; 19,04 \%)$, e em 2012 , em razão da elevada densidade relativa $(28,9 \%)$ e dominância (20,87 \%). Dalbergia miscolobium apresentou maiores valores de dominância neste período $(13,5 ; 13,1 ; 12,8 \%)$ em relação às outras espécies, mas não em 2012 (11,4 \%). Guapira graciliflora se manteve na terceira posição também devido à dominância. De 
1988 a 1990, Myrsine guianensis mostrou aumento na densidade, mas Dalbergia miscolobium, Guapira graciliflora e Guapira noxia tiveram pequena redução.

No período de 1988 a 1994, os indivíduos vivos foram distribuídos em sete classes de altura nas duas áreas; em 2012, o número de classes passou para 10 na Área 1 e oito na Área 2. Nas duas áreas, e em todo período do estudo, as distribuições dos indivíduos vivos em classes de altura não diferiram significativamente de acordo com o teste de Kolmogorov-Smirnov ( $>00,05)$, indicando que as amostras apresentaram a mesma distribuição (Figura 2.8; Figura 2.9).
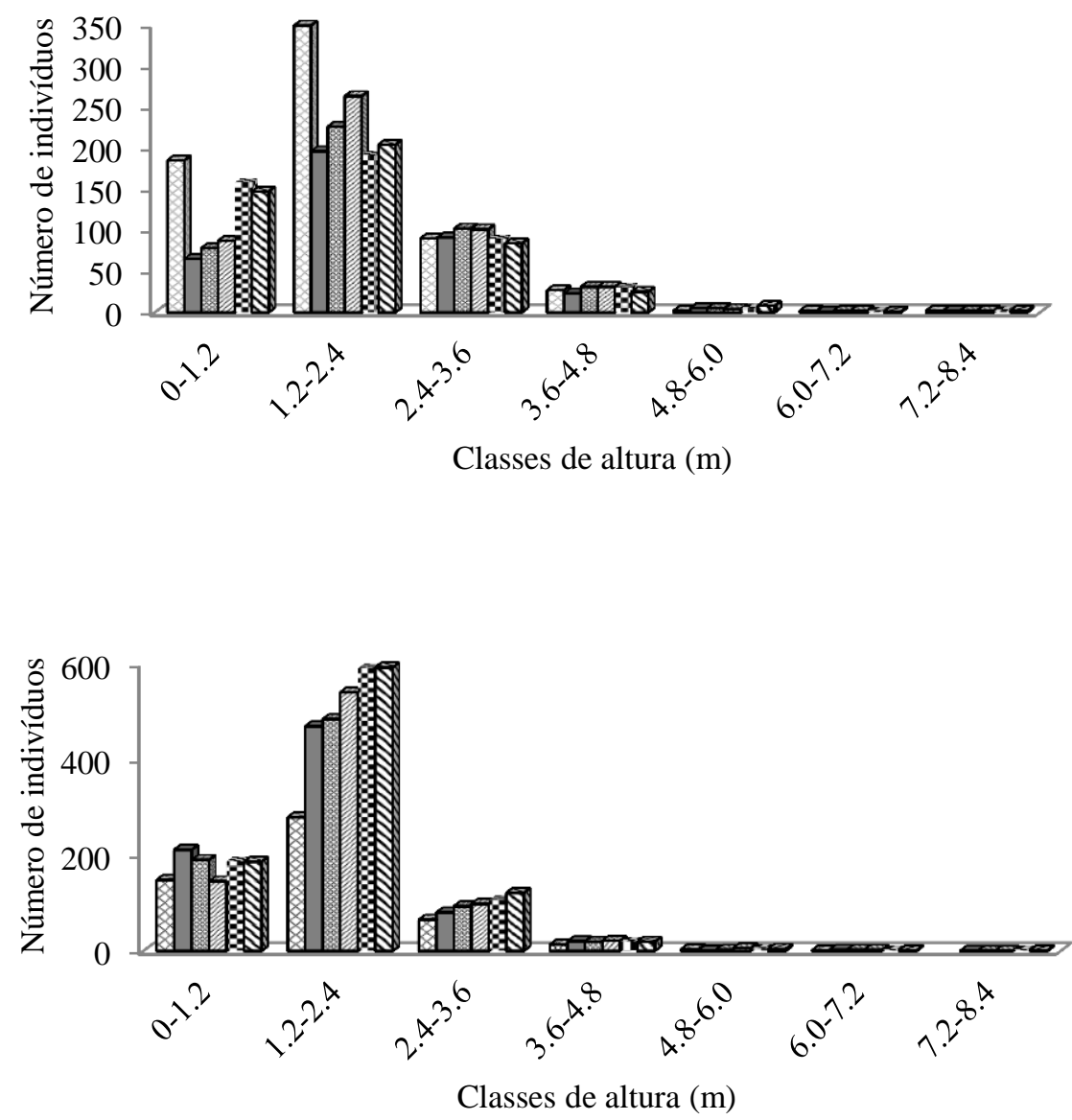

Figura 2.8 - Distribuição dos indivíduos arbóreo-arbustivos vivos em classes de altura, em seis ocasiões do monitoramento (1988 a 1994), em duas áreas de Cerrado sentido restrito com diferentes históricos de fogo, sendo: $\mathrm{A}=$ Área 1; $\mathrm{B}=$ Área 2. Obs.: foram incluídos indivíduos que tiveram mortalidade aérea e rebrota. 


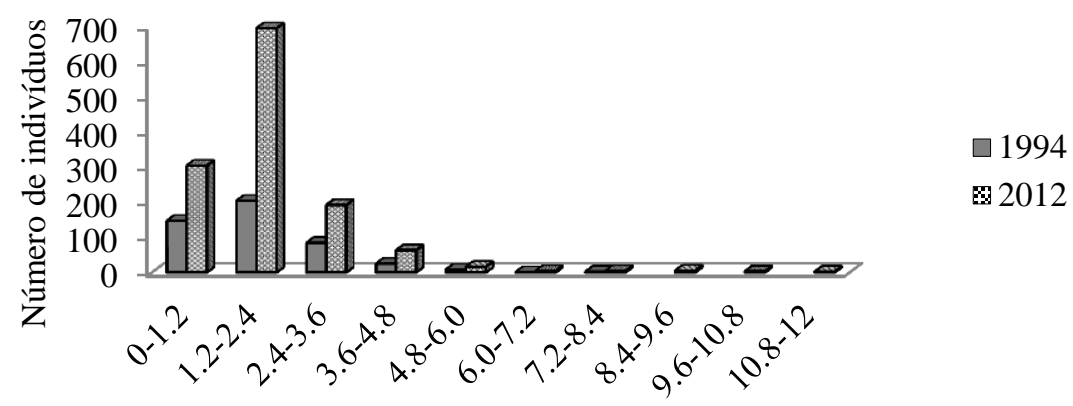

Classes de altura (m)

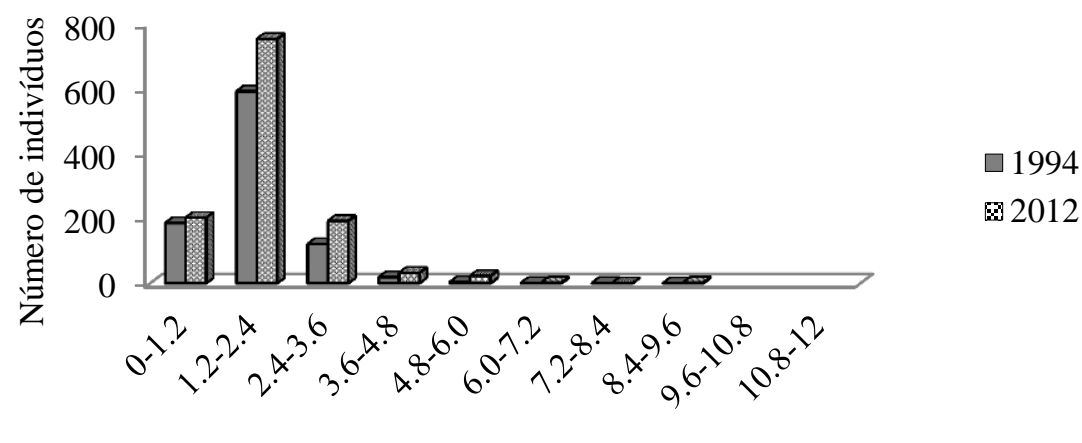

Classes de altura (m)

Figura 2.9 - Distribuição dos indivíduos arbóreo-arbustivos vivos em classes de altura, em duas ocasiões do monitoramento (1994 e 2012), em duas áreas de Cerrado sentido restrito com diferentes históricos de fogo, sendo: $\mathrm{A}=$ Área 1; $\mathrm{B}=$ Área 2. Obs.: foram incluídos indivíduos que tiveram mortalidade aérea e rebrota.

A distribuição em classes de altura na Área 1, no período de tratamento com fogo, de 1988 a 1994, mostra maior número de indivíduos na segunda classe de altura (1,2-2,4 $\mathrm{m}$ ), em todos os anos. Nota-se redução no número de indivíduos da primeira e segunda classes após a primeira queimada de 1988, em 1990. No entanto, após a segunda queimada de 1990, houve aumento no número de indivíduos da primeira classe, de 1991 a 1994. Até o ano de 1992, havia maior concentração dos indivíduos na segunda classe de altura (frequência relativa de 53\% em 1988; 51\% em 1990; 51\% em 1991; 53\% em 1992). Após a terceira queimada de 1992 o maior número de indivíduos ainda ficou concentrado na segunda classe (frequência relativa de $40 \%$ em 1993; $43 \%$ em 1994), porém o percentual de indivíduos aumentou na primeira classe quando comparado aos anos anteriores (frequência relativa de 17\% em 1990; $17 \%$ em 1991; 18\% em 1992; 33\% em 1993; 31\% em 1994). 
Antes da primeira queimada, na Área 1, havia um elevado número de indivíduos nas duas primeiras classes (81\% em 1988), mas houve redução em 1990 (68\%) e 1991 (68\%), indicando que o fogo afetou os indivíduos menores. Depois, de 1993 a 1994, houve aumento no número de indivíduos nas duas primeiras classes (frequência relativa de $71 \%$ em 1992; 73\% em 1993; 75\% em 1994), mas com aumento no percentual na primeira classe e redução na segunda classe, em 1993 e 1994. Nestes anos alguns indivíduos haviam perdido a parte aérea e rebrotado, reduzindo assim o percentual de indivíduos na segunda e terceira classe e aumentando na primeira classe. Houve aumento no percentual da terceira classe de 1988 (13\%) a 1990 e 1991 (23\%), com o estabelecimento de algumas espécies nesta classe.

Na Área 2, de 1988 a 1994, e de 1994 a 2012, houve cerca de 80\% dos indivíduos concentrados nas duas primeiras classes de altura (frequência relativa de 84\% em 1988; 87\% em 1990; 85\% em 1991; 84\% em 1992; 84\% em 1994; 79\% em 2012). Em 2012 um menor percentual de indivíduos estava na primeira classe (17\%) quando comparado com 1988 (29\%). Em 1988 ainda havia um grande número de indivíduos em processo de regeneração e nos anos seguintes até 2012 algumas espécies alcançaram outras classes superiores.

As distribuições dos indivíduos vivos em classes de diâmetro nas duas áreas apresentaram curva com padrão de distribuição "j” invertido, comumente encontrado em comunidades em processo de regeneração e recrutamento, onde há maior concentração dos indivíduos na menor classe. As distribuições não diferiram nas duas áreas e em todos os anos do estudo (1990 a 1994 e 2012) de acordo com o teste de Kolmogorov-Smirnov (p>0,05) (Figura 2.10; Figura 2.11). 


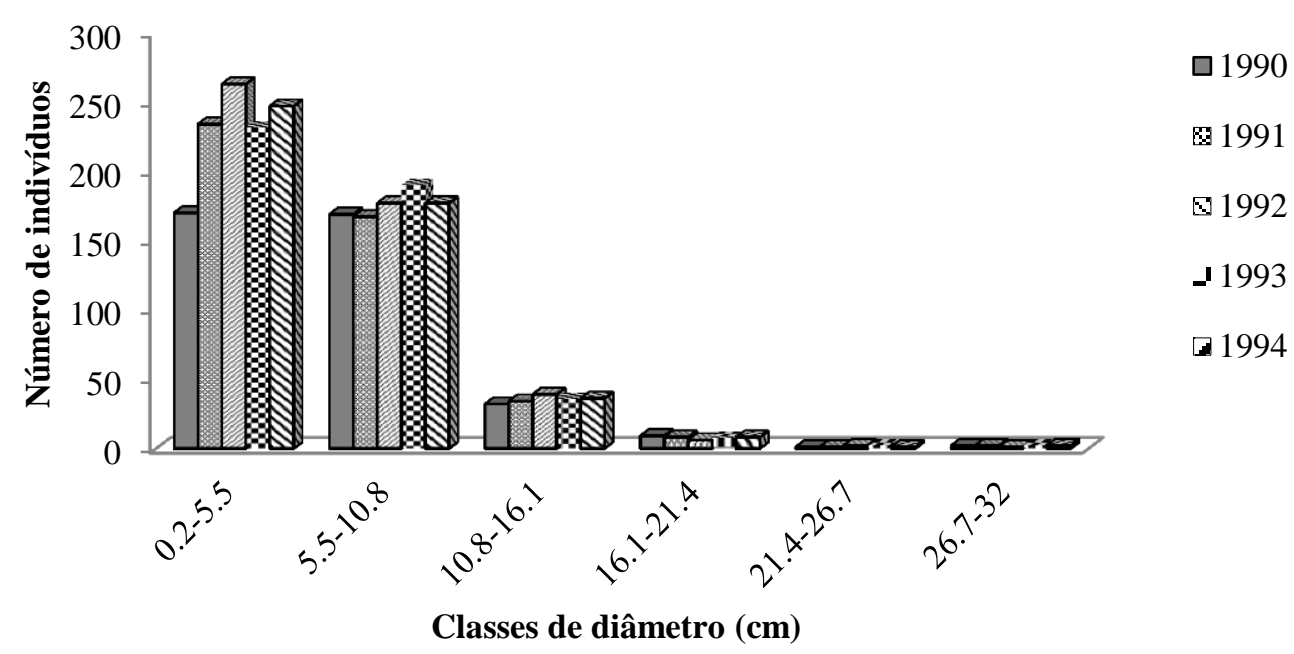

B

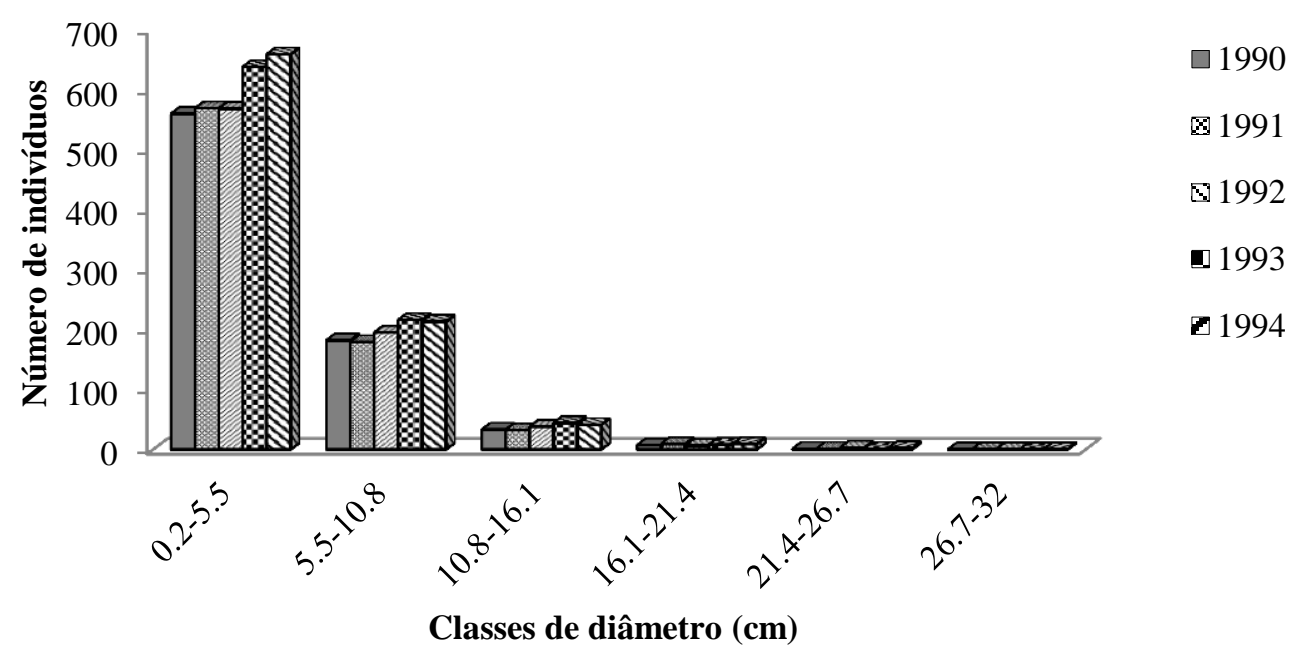

Figura 2.10 - Distribuição dos indivíduos arbóreo-arbustivos vivos em classes de diâmetro, em cinco ocasiões do monitoramento (1990 a 1994), em duas áreas de Cerrado sentido restrito com diferentes históricos de fogo, sendo: $\mathrm{A}=$ Área 1; $\mathrm{B}=$ Área 2. Obs.: foram incluídos indivíduos que tiveram mortalidade aérea e rebrota. 


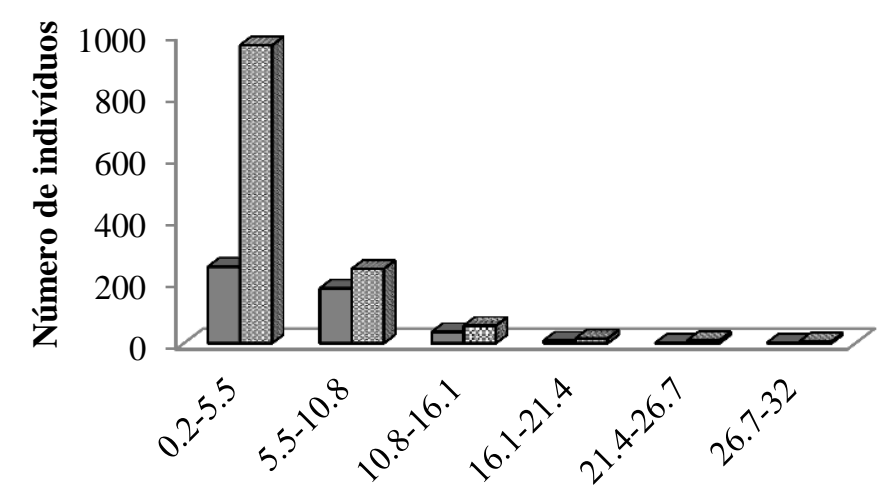

Classes de diâmetro $(\mathrm{cm})$

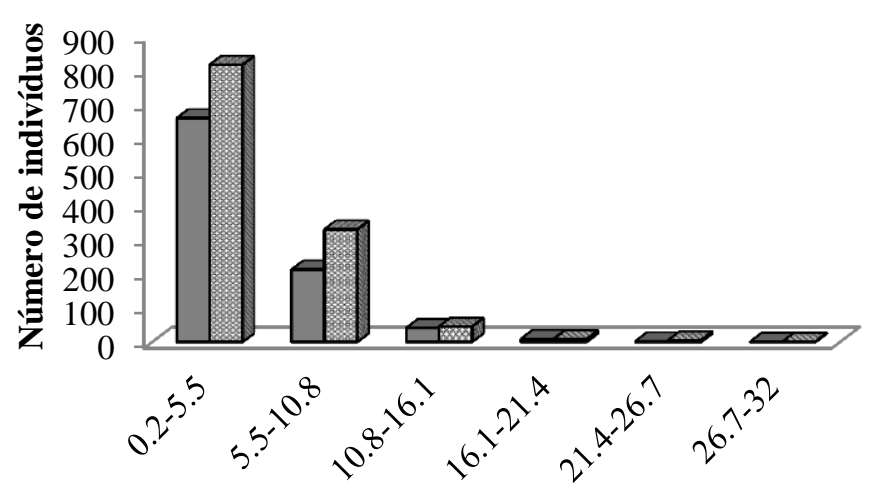

Classes de diâmetro (cm)

Figura 2.11 - Distribuição dos indivíduos arbóreo-arbustivos vivos em classes de diâmetro, em duas ocasiões do monitoramento (1994 e 2012), em duas áreas de Cerrado sentido restrito com diferentes históricos de fogo, sendo: $\mathrm{A}=$ Área 1; B= Área 2. Obs.: foram incluídos indivíduos que tiveram mortalidade aérea e rebrota.

Na Área 1, no ano de 1990, dois anos após a primeira queimada de 1988, o número de indivíduos nas duas primeiras classes é muito próximo, 170, com frequência relativa de 44,4\%, e 169, com frequência igual a 44,1\%. Em 1988 não foram feitas medidas dos diâmetros, e provavelmente, após a primeira queimada, um grande número de indivíduos na primeira e segunda classe morreu com a passagem do fogo já que o número total de indivíduos reduziu de 657 para 383. Além disso, poucos indivíduos da primeira classe conseguiram alcançar a segunda classe de diâmetro. A segunda queimada em 1990 facilitou a regeneração e entrada de novos indivíduos na primeira classe em 1991, quando 
o número subiu para 234. No período de 1991 a 1994, cerca de 50\% dos indivíduos estavam distribuídos na primeira classe; a primeira e segunda classes incluíam cerca de 90\% dos indivíduos. No período sem fogo de 1994 a 2012, o número de indivíduos da primeira classe, com até 5,5cm de diâmetro, passou de $247(52,4 \%)$ para $963(74,8 \%)$, o percentual aumentou pouco mais de $20 \%$. Já o número de indivíduos na segunda classe passou de 177, que corresponde a 37,58\% do total de indivíduos em 1994, para 240 (18,63\% do total) em 2012, com uma redução de cerca de $20 \%$ no percentual de indivíduos nesta classe, mostrando que a comunidade ainda está em processo de regeneração, com maior número de indivíduos na primeira classe e poucos nas classes superiores de diâmetro.

$\mathrm{Na}$ Área 2, em todos os anos, notou-se o mesmo comportamento, ou seja, maior número de indivíduos na menor classe de diâmetro $(0,2-5,5 \mathrm{~cm})$. A distribuição também segue o padrão "J" invertido, com um número muito grande de indivíduos na primeira classe de diâmetro. Cerca de 95\% dos indivíduos ficaram concentrados nas duas primeiras classes, sendo que na primeira o percentual ficou próximo de $71 \%$ de 1990 a 1994, mas em 2012 reduziu para 68\%. Apesar do número de indivíduos ter aumentado de 1994 para 2012, período sem fogo, o percentual de indivíduos na primeira classe diminuiu, mas aumentou na segunda classe, indicando que alguns indivíduos que se estabeleceram, alcançaram classes de níveis superiores de diâmetro.

\section{Caracterização do solo}

Os resultados encontrados em 2013 foram semelhantes aos valores observados no período de 1988 a 1994, por Spera et al. (2000) e Braga et al. (1998). Nas duas áreas, em 2013, foram encontrados menores valores de silte e de areia, do que argila. Não foram encontradas diferenças significativas entre os teores de argila, bem como dos teores de areia, para cada profundidade, entre as duas áreas (Tabela 2.5). Observou-se diferença significativa $(\mathrm{p}<0,05)$ somente nos valores de silte na profundidade de 0 a $15 \mathrm{~cm}$, entre a Área 1 e Área 2. Estes menores valores de silte da Área 1, em relação à Área 2, estão de acordo com os resultados encontrados nas análises de 1994. Nos resultados destas análises atribuíram-se os menores valores de silte e maiores de argila da área com fogo, à fatores genéticos do solo, uma vez que as parcelas da Área 2 ficam mais próximas da borda da chapada. Essas diferenças não alteraram as demais características (SPERA et al., 2000). 
Tabela 2.5 - Média (g. $\left.\mathrm{kg}^{-1}\right)$ e desvio padrão, entre parênteses, dos resultados da análise granulométrica em diferentes profundidades, em duas áreas (Área 1 e Área 2) com diferentes históricos de fogo, em Cerrado sentido restrito, em Planaltina (DF), em 2013.

\section{$\begin{array}{llll}\text { Profundidade } & \text { Silte } & \text { Argila } & \text { Areia }\end{array}$ \\ $(\mathbf{c m})$}

\begin{tabular}{ccccccc}
\hline & Área 1 & Área 2 & Área 1 & Área 2 & Área 1 & Área 2 \\
$0-15$ & $91 \mathrm{a} \mathrm{(8)}$ & $106 \mathrm{~b}(3)$ & $764 \mathrm{a}(22)$ & $778 \mathrm{a}(37)$ & $145 \mathrm{a}(25)$ & $116 \mathrm{a}(22)$ \\
$15-30$ & $115 \mathrm{a}(42)$ & $129 \mathrm{a}(56)$ & $752 \mathrm{a}(57)$ & $762 \mathrm{a}(53)$ & $132 \mathrm{a}(24)$ & $109 \mathrm{a}(23)$ \\
$30-45$ & $67 \mathrm{a}(22)$ & $100 \mathrm{a}(73)$ & $803 \mathrm{a}(58)$ & $798 \mathrm{a}(67)$ & $130 \mathrm{a}(25)$ & $101 \mathrm{a}(21)$ \\
\hline
\end{tabular}

*Letras diferentes indicam diferenças estatísticas entre a Áreas 1 e Área 2, em cada profundidade $(\mathrm{p}<0,05)$, pelo teste de t pareado.

Os resultados (Tabela 2.6) mostraram que o solo das duas áreas de estudo é caracterizado como ácido a muito ácido, com elevados níveis de Alumínio trocável e baixos teores de cálcio, magnésio, fósforo e potássio (SOUSA; LOBATO, 2004).

Tabela 2.6 - Resultados da análise química em duas áreas (Área 1, Área 2), com diferentes históricos de fogo, em Cerrado sentido restrito em Planaltina (DF), em diferentes profundidades, em 2013.

\begin{tabular}{|c|c|c|c|c|c|c|c|c|}
\hline \multirow[t]{2}{*}{ Profundidade } & \multicolumn{2}{|c|}{$\begin{array}{c}\text { Ca } \\
\mathrm{cmol}_{\mathrm{c}} \cdot \mathrm{dm}^{-3}\end{array}$} & \multicolumn{2}{|c|}{$\begin{array}{c}\mathbf{K} \\
\mathrm{mg} . \mathrm{l}^{-1}\end{array}$} & \multicolumn{2}{|c|}{$\begin{array}{c}\mathbf{P} \\
\mathrm{mg} \cdot \mathrm{l}^{-1}\end{array}$} & \multicolumn{2}{|c|}{$\begin{array}{c}\mathbf{M g} \\
\mathrm{cmol}_{\mathrm{c}} \cdot \mathrm{dm}^{-3}\end{array}$} \\
\hline & Área1 & Área2 & Área1 & Área2 & Área1 & Área2 & Área1 & Área2 \\
\hline $0-15$ & 0,12 & 0,13 & 42 & 42 & 0,82 & 0,72 & 0,11 & 0,11 \\
\hline $15-30$ & 0,08 & 0,11 & 23 & 31 & 0,35 & 0,55 & 0,07 & 0,08 \\
\hline $30-45$ & 0,07 & 0,08 & 19 & 20 & 0,30 & 0,29 & 0,06 & 0,06 \\
\hline $45-60$ & 0,07 & 0,08 & 13 & 13 & 0,38 & 0,30 & 0,06 & 0,05 \\
\hline $60-75$ & 0,06 & 0,07 & 9 & 11 & 0,22 & 0,22 & 0,04 & 0,05 \\
\hline $75-90$ & 0,08 & 0,08 & 15 & 10 & 0,30 & 0,20 & 0,06 & 0,05 \\
\hline $90-105$ & 0,09 & 0,09 & 17 & 9 & 0,25 & 0,32 & 0,08 & 0,04 \\
\hline $105-120$ & 0,09 & 0,09 & 13 & 10 & 0,24 & 0,43 & 0,07 & 0,05 \\
\hline
\end{tabular}

\begin{tabular}{|c|c|c|c|c|c|c|c|c|}
\hline \multirow[t]{2}{*}{ Profundidade } & \multicolumn{2}{|c|}{$\begin{array}{c}\text { Al } \\
\mathrm{cmol}_{\mathrm{c}} \cdot \mathrm{dm}^{-3}\end{array}$} & \multicolumn{2}{|c|}{$\mathbf{p H}$} & \multicolumn{2}{|c|}{$\begin{array}{c}\mathbf{H}+\mathbf{A l} \\
\mathrm{cmol}_{\mathrm{c}} \cdot \mathrm{dm}^{-3}\end{array}$} & \multicolumn{2}{|c|}{$\begin{array}{c}\text { Matéria Orgânica } \\
\%\end{array}$} \\
\hline & Área1 & Área2 & Área1 & Área2 & Área1 & Área2 & Área1 & Área2 \\
\hline $0-15$ & 0,86 & 0,81 & 4,16 & 4,29 & 7,18 & 7,51 & 3,51 & 3,39 \\
\hline $15-30$ & 0,46 & 0,46 & 4,31 & 4,49 & 5,54 & 5,88 & 2,58 & 2,73 \\
\hline $30-45$ & 0,26 & 0,27 & 4,53 & 4,58 & 4,45 & 5,13 & 2,17 & 2,15 \\
\hline $45-60$ & 0,11 & 0,13 & 4,71 & 4,78 & 3,64 & 3,98 & 1,72 & 1,71 \\
\hline $60-75$ & 0,05 & 0,07 & 4,87 & 4,84 & 3,16 & 3,73 & 1,47 & 1,58 \\
\hline $75-90$ & 0,01 & 0,02 & 4,96 & 4,96 & 2,69 & 3,20 & 1,39 & 1,34 \\
\hline $90-105$ & 0,01 & 0,03 & 5,06 & 5,02 & 2,53 & 3,14 & 1,21 & 1,24 \\
\hline $105-120$ & 0,01 & 0,01 & 5,12 & 4,98 & 2,47 & 3,12 & 1,29 & 1,33 \\
\hline
\end{tabular}


Os valores do $\mathrm{pH}$ em água foram similares nas duas áreas, e variou de 4 a 5,1, conforme a profundidade, indicando que o solo é ácido a muito ácido. Com relação aos níveis de alumínio trocável, os valores diminuíram, nas duas áreas de acordo com a profundidade. Os valores mais elevados nas primeiras profundidades $(0,87$ e 0,83 $\mathrm{cmol}_{\mathrm{c}} \cdot \mathrm{dm}^{-3}$ ) podem estar relacionados aos menores valores de $\mathrm{pH}$, e são indicativos de solo ácido (BRAGA et al., 1998). Os níveis de $\mathrm{H}+\mathrm{Al}$ também foram similares nas duas áreas e diminuíram com a profundidade (Tabela 2.6).

Os níveis de cálcio nas duas áreas foram similares, variando conforme a profundidade com valores entre 0,1 e $0,06 \mathrm{cmol}_{\mathrm{c}} \cdot \mathrm{dm}^{-3}$, mas com teores mais elevados na profundidade de 0 a $15 \mathrm{~cm}\left(0,1 \mathrm{cmol}_{\mathrm{c}} \cdot \mathrm{dm}^{-3}\right)$ nas duas áreas. Os níveis de Magnésio foram similares nas duas áreas, com pequenas variações, mas com maiores valores na profundidade de 0 a $15 \mathrm{~cm}$. Nas duas áreas os teores de Magnésio ficaram entre 0,1 e 0,04 $\mathrm{cmol}_{\mathrm{c}} \cdot \mathrm{dm}^{-3}$. Os teores de cálcio são considerados, portanto, baixos (até $30 \mathrm{~cm}$ ) ou muito baixos na profundidade abaixo de $30 \mathrm{~cm}$ e os de magnésio são baixos (SOUSA; LOBATO, 2004).

Os teores de fósforo nas duas áreas também foram similares, e muito baixos (SOUSA; LOBATO, 2004). Os níveis de fósforo variaram com a profundidade nas duas áreas. Os maiores valores foram observados na profundidade até $15 \mathrm{~cm}$, sendo $0,9 \mathrm{mg} .1^{-1}$ na Área 1, e 0,7 mg. $\mathrm{l}^{-1}$ na Área 2. Os níveis de potássio diminuíram com a profundidade nas duas áreas, mas na área 1, na profundidade de 75 a 105 aumentou e depois voltou a diminuir. Até $15 \mathrm{~cm}$ de profundidade os teores foram de $39 \mathrm{mg} . \mathrm{l}^{-1}$ na Área 1 e $44 \mathrm{mg} . \mathrm{l}^{-1} \mathrm{na}$ Área 2. Foram encontrados teores médios de matéria orgânica, na camada até $15 \mathrm{~cm}$, e teores baixos nas profundidades abaixo de $15 \mathrm{~cm}$ (SOUSA; LOBATO, 2004). Os níveis de matéria orgânica foram similares nas duas áreas, variando com a profundidade em cerca de $3,5 \%$ a 1,3\%. Estes resultados estão de acordo com as análises realizadas de 1988 a 1994 , onde Braga et al. (1998) também encontraram valores de matéria orgânica variando com a profundidade.

\subsection{DISCUSSÃO}

\section{Florística}

Os resultados do monitoramento no período com queimadas bienais de 1988 a 1994 e em 2012, após 18 anos sem fogo, evidenciaram mudanças com relação à composição florística da comunidade arbóreo-arbustiva. Após a primeira queimada prescrita de 1988, 
na Área 1, observou-se uma redução de cerca de $42 \%$ no número de indivíduos (de 656 para 383). A Área 1 ficou por um longo período sem queimar, desde 1978, e com a primeira queimada de 1988, a maior redução dos indivíduos vivos em 1990, em comparação aos anos seguintes, pode ter sido em função da eliminação ou diminuição das espécies sensíveis ao fogo e maior dominância de espécies mais resistentes (SAMBUICHI, 1991). Em outra área de Cerrado sentido restrito, no DF, Almeida et al. (2014) também relacionaram a redução no número de indivíduos, após a passagem do fogo, à presença de algumas espécies sensíveis ao distúrbio. Dentre as espécies observadas, 13 foram representadas por apenas um indivíduo, em pelo menos um dos levantamentos (de 1988 a 2012), na Área 1, e 26 na Área 2. Após a primeira queimada de 1988, as espécies Eremanthus goyazensis, Protium ovatum, Andira humilis, Senna rugosa, Miconia albicans, Chomelia ribesioides e Coridiera sessilis, não tiveram registros de ocorrência na área até 1994, antes do fogo acidental, sendo, portanto, consideradas sensíveis ao distúrbio. No entanto, outras 33 espécies que ocorreram em 1988, tais como Tachigali subvelutina e Styrax ferrugineus, tiveram redução no número de indivíduos após a primeira queimada, mas se mantiveram ao longo de todo o período de queimadas, demonstrando que, apesar da sensibilidade ao fogo, são resistentes a ele.

Algumas espécies foram favorecidas com a proteção contra o fogo, nas duas áreas. Guapira graciliflora, por exemplo, teve redução no número de indivíduos em 1990, mas o período sem fogo fez com que sua abundância subisse em 2012. Myrsine guianensis, na Área 1, também teve redução na sua população em 1990, porém aumentou em 2012. Esta espécie é considerada sensível, e, de acordo com Hoffmann (1999), há um declínio na sua população diante de regimes de queima em intervalos de 1 a 3 anos. Dentre as espécies que podem ser consideradas resistentes ao distúrbio, algumas tiveram aumento em abundância durante o período com queimadas, como Byrsonima verbascifolia, e outras foram indiferentes e mantiveram o mesmo número de indivíduos, como Hymenaea stigonocarpa e Piptocarpha rotundifolia. Medeiros (2002) também caracterizou Byrsonima verbascifolia como resistente ao fogo devido às baixas taxas de mortalidade, em área com queimadas anuais, em agosto.

A família Fabaceae, mais rica em espécies nas duas áreas, está entre as dez famílias mais representadas no bioma Cerrado (MENDONÇA et al., 2008), concordando com outros estudos realizados no Distrito Federal que também encontraram resultados semelhantes (ASSUNÇÃO; FELFILI, 2004; FIEDLER et al., 2004; LIBANO; FELFILI, 2006; ALMEIDA et al., 2014). A importância da família Fabaceae no Cerrado pode ser 
atribuída à capacidade de fixação biológica de nitrogênio de muitas espécies, o que facilita a regeneração em solos pobres e degradados (SOUZA et al., 2010; SILVA; FELFILI, 2012).

O fogo não influenciou a riqueza nas duas áreas de 1988 a 1994, e a proteção da área contra o fogo por 18 anos também não influenciou a riqueza de espécies em 2012. O total de espécies, variando de 49 a 68, durante o monitoramento nas duas áreas (Área 1, Área 2) está de acordo com o número de espécies mencionado para o Cerrado sentido restrito no DF (ASSUNÇÃO; FELFILI, 2004; FIEDLER et al., 2004; ALMEIDA et al., 2014). Porém, em dois fragmentos de Cerrado sentido restrito no Maranhão, Queiroga (2001), que também mediu todos os indivíduos com altura igual ou superior a um metro, registrou um número maior de espécies, 144. Este valor é considerado elevado quando comparado a outras áreas, no entanto, o autor incluiu arbustos e subarbustos, além de árvores. Ao contabilizar somente as árvores e arbustos, foram registradas 67 e 14 espécies, respectivamente, valores mais próximos ao encontrado nas duas áreas da Reserva da Embrapa Cerrados.

A riqueza de espécies se manteve ao longo do período de queimadas com algumas espécies sendo eliminadas e outras incluídas, mas com a manutenção da maioria; das 54 espécies observadas em 1988, oito foram excluídas e outras três incluídas em 1990. Das 74 espécies que foram registradas na Área 1, em todo o período, 45 se mantiveram todos os anos e 13 apareceram somente em 2012. Na Área 2, das 73 espécies, 44 ocorreram todos os anos e 14 apareceram somente no ano de 2012.

Em um Cerrado sentido restrito no Jardim Botânico de Brasília (DF), o fogo também não afetou a riqueza de espécies quando se comparou uma área queimada com outra não queimada (MOREIRA, 2000). E a manutenção da riqueza, com saída e entrada de espécies, também foi observada em outra área de Cerrado sentido restrito, na Fazenda Água Limpa/UnB (DF), onde as modificações foram relacionadas aos eventos de fogo, sendo que das 69 espécies registradas, 52 eram comuns nos levantamentos realizados por 18 anos (LIBANO; FELFILI, 2006).

A exclusão do fogo favoreceu a entrada de algumas espécies, com o aumento de 49, em 1994, para 68, em 2012, na Área 1, e de 50 para 63 na Área 2, indicando alta resiliência da comunidade frente ao distúrbio. A entrada de novas espécies também foi registrada em outra área de Cerrado sentido restrito, no Distrito Federal, protegida do fogo, em estudo de Henriques e Hay (2002), que observaram aumento no número de espécies, gêneros e famílias e alta taxa de imigração. Os resultados sugerem, desta forma, que, mesmo diante 
de queimadas frequentes, tem-se a manutenção e a entrada de algumas espécies, principalmente, daquelas menos sensíveis ao distúrbio.

Com relação à similaridade florística, houve diferenças na similaridade qualitativa (presença e ausência das espécies) e quantitativa (abundância de espécies) entre a Área 1 e a Área 2, de 1988 até 1994. No entanto, estas duas áreas, que não eram similares até 1994, com a proteção por 18 anos, tornaram-se similares quanto à composição das espécies. Em outra área de Cerrado sentido restrito, no Distrito Federal, com três queimadas, em um período de 18 anos, Libano e Felifili (2006) também observaram alta similaridade qualitativa. Assim, os resultados alcançados e os encontrados por Libano e Felifili (2006) demonstram que, mesmo com a ocorrência de queimadas frequentes, a exclusão do distúrbio fogo possibilita o retorno de algumas espécies e com isso, a manutenção da composição florística.

Quanto à diversidade, o perfil de diversidade mostrou maior diversidade na Área 2, em 1988 (Figura 2.5). As diferenças entre as duas áreas neste ano podem ter sido em decorrência da heterogeneidade florística frequentemente relatada em outros estudos em Cerrado sentido restrito (FELFILI; SILVA JR., 1993; FELFILI; FELFILI, 2001; FELFILI et al., 2004; CARVALHO et al., 2008), ou dos efeitos da fragmentação (SCARIOT et al., 2003). No período de 1990 a 1994, na Área 1, ocorreu sobreposição das curvas mostrando diversidade similar, e indicando que, mesmo com o fogo frequente, manteve-se a diversidade da comunidade. Na Área 1, a riqueza e equabilidade foram similares de 1990 a 1994, com baixa dominância de espécies e maior equabilidade. E, na Área 2, houve sobreposição das curvas de 1990 a 1994 e diversidade similar, porém maior dominância das espécies e menor equabilidade.

Diante dos resultados mencionados, cabe enfatizar que o fogo pode reduzir a dominância de plantas estabelecidas, favorecer o estabelecimento de algumas espécies (HOFFMANN, 1996; DIAS NETO et al., 2008) e eliminar espécies sensíveis ao distúrbio (SANBUICHI, 1991). Assim, as queimadas bienais podem ter favorecido espécies mais resistentes e eliminado outras mais sensíveis, ocasionando uma baixa dominância de espécies e maior equabilidade na Área 1, e tornando as duas áreas diferentes em diversidade, mas mantendo a diversidade em cada área. Em outra área de Cerrado sentido restrito, em Nova Xavantina (MT), Lima et al. (2009) também observaram pouca influência do fogo na diversidade. E, quanto à manutenção da diversidade, esta também foi constatada em duas áreas de Cerrado sentido restrito com diferentes frequências de fogo por Ribeiro et al. (2012), em Barra do Garças (MT). 
O período de proteção contra o fogo proporcionou melhores condições para que algumas espécies tivessem aumento em densidade e dominância. Após 18 anos sem fogo, em 2012, as duas áreas mostraram diferenças na diversidade; sendo a Área 1 mais diversa, com maior riqueza de espécies e equabilidade. Já a Área 2 apresentou menor equabilidade, com alta dominância de espécies, menor uniformização das abundâncias. Algumas espécies, que já eram abundantes, foram favorecidas com a proteção contra o fogo. Myrsine guianensis, por exemplo, espécie considerada sensível ao fogo, aumentou a abundância nas duas áreas, possivelmente, devido ao estímulo do fogo tanto na reprodução sexuada quanto na vegetativa. Esta espécie, na Área 2, dobrou o número de indivíduos de 175 (1994) para 348 (2012), o que equivale a 29\% do número de indivíduos total da área. O maior número de espécies com apenas uma ocorrência também foi observado na Área 2. Em 2012, um indivíduo da espécie da família Lauraceae, não identificada, que não é comum no Cerrado sentido restrito, ocorreu na Área 2. Provavelmente, a remoção da cobertura vegetal e da serapilheira pelo fogo de 1994 (SILVA et al., 2011) ou o pastejo do gado bovino na área favoreceram a entrada desta espécie.

Desta forma, as diferenças observadas entre as duas áreas podem estar associadas aos efeitos da fragmentação, que também variam com o histórico, tamanho e forma do fragmento, impactos das ações humanas, grau de isolamento e com a sensibilidade da comunidade e dos indivíduos de cada espécie a estes processos (SCARIOT et al., 2003). Os fragmentos menores, geralmente, estão mais sujeitos aos diversos efeitos decorrentes da fragmentação e da ação do fogo, gado e invasão por gramíneas exóticas (CARMO et al., 2011). Com isso, os diferentes históricos de fogo das duas áreas, o pisoteio esporádico do gado bovino, com a invasão de gramíneas exóticas (Capítulo 4), e a pressão antrópica do entorno com a construção de condomínios após 1994 e a criação do assentamento de reforma agrária próximo à área de estudo, em 2009, também podem ter influenciado as respostas da comunidade após a exclusão do fogo por 18 anos, tornando as duas áreas diferentes em diversidade, com maior dominância de espécies e menor equabilidade na Área 2.

\section{Estrutura fitossociológica}

As queimadas frequentes reduziram a densidade da comunidade arbóreo-arbustiva, e um período de exclusão do fogo aumentou este parâmetro nas duas áreas. Em 1988 a Área 1 com densidade estimada em 3280 ind.ha $^{-1}$ teve redução de 41,4\% em 1990. O 
acúmulo de biomassa na camada superficial do solo, principalmente gramíneas, aumenta a probabilidade de ignição, a intensidade e a extensão do fogo (CIANCIARUSO et al., 2010), e desta forma, em áreas protegidas, o risco de incêndios será maior podendo resultar em incêndios de maiores proporções (SILVA et al., 2011), justificando a maior perda em densidade após a primeira queimada de 1988. Na área estudada, após a segunda queimada, a densidade aumentou em 11,2\% em 1991; já a terceira queimada reduziu em 15,5\% a densidade. A Área 2 teve aumento em densidade em todos os anos do estudo, e o período de proteção do fogo por 18 anos também favoreceu o aumento da densidade nas duas áreas.

No período de 1988 a 1994, houve uma redução de 40,5\% na densidade estimada da área com queimadas bienais. Percentuais inferiores a este foram observados em Cerrado sentido restrito na Fazenda Água Limpa (DF), em um período de 12 anos, com três queimadas acidentais, onde a densidade reduziu em 30\% (SILVA, 1999). Já, em Nova Xavantina (MT), Lima et al. (2009) observaram redução de 17,5\% em cinco anos, com duas queimadas. Estas diferenças na redução da densidade da vegetação pelo fogo podem estar relacionadas à época, intensidade e frequência das queimadas (MIRANDA et al., 2010), com o favorecimento de algumas espécies e exclusão de outras mais sensíveis (SAMBUICHI, 1991; SILVA et al., 2011). Desta forma, algumas espécies consideradas sensíveis ao fogo pela redução na densidade, como Guapira graciliflora, na Reserva da Embrapa Cerrados, mostraram-se resistentes e permaneceram na área mesmo com a reincidência das queimadas.

As queimadas bienais frequentes influenciaram a área basal quando comparado à área sem fogo. No entanto, o fogo não reduziu a área basal da comunidade na Área 1 após a segunda queimada, onde os valores muito próximos ao longo do tempo (de 1990 a 1994), provavelmente, devido à maior mortalidade dos indivíduos mais finos nesta área, ou o crescimento radial foi suficiente para repor a perda em área basal decorrente da mortalidade (LIMA et al., 2009). Resultados semelhantes aos observados na Área 2, com maiores valores em relação à Área 1, com queimadas bienais, foram encontrados por Ramos (1990), também no Distrito Federal, onde a área basal de espécies arbóreas foi maior em área protegida por 13 anos, comparado à área queimada a cada dois anos. A proteção do fogo, em geral, aumenta o número de indivíduos com troncos grossos e poucos ramos (MISTRY, 1998), e desta forma, o período de exclusão do fogo por 18 anos pode ter favorecido o aumento em área basal nas duas áreas, em $2012\left(18,85\right.$ e 16,7 m².ha $\left.{ }^{-1}\right)$. 
Em outras áreas do Distrito Federal foram observados valores menores de área basal, onde Andrade et al. (2002) encontraram área basal equivalente a 13,28 $\mathrm{m}^{2} \cdot \mathrm{ha}^{-1}$ na Reserva Ecológica do IBGE-DF, incluindo espécies da família Velloziaceae e Arecaceae. Já Felfili e Silva Jr. (1993) encontraram 10,64 $\mathrm{m}^{2} \cdot \mathrm{ha}^{-1}$ na APA do Gama-Cabeça de Veado e 10,76 m².ha ${ }^{-1}$ em Águas Emendadas-DF; e Assunção e Felfili (2004), 9,53 $\mathrm{m}^{2} \cdot \mathrm{ha}^{-1}$ na APA do Paranoá-DF. Um valor mais próximo ao estimado para as duas áreas na Embrapa Cerrados em 2012 foi observado em uma área de Cerrado sentido restrito com histórico de intervenções humanas na Floresta Nacional de Paraopeba (MG), onde Balduíno et al. (2005) estimaram área basal de $18,14 \mathrm{~m}^{2} \cdot \mathrm{ha}^{-1}$, incluindo a família Arecaceae.

A variação em área basal dos estudos mencionados acima evidencia a heterogeneidade florística frequentemente encontrada em Cerrado sentido restrito onde, mesmo em áreas próximas, as comunidades podem ser estruturalmente diferenciadas (FELFILI; SILVA JR., 1993; FELFILI; FELFILI, 2001; FELFILI et al., 2004; CARVALHO et al., 2008). Mas, por outro lado, também pode estar relacionada às diferenças nos critérios de inclusão, já que neste estudo foram incluídas espécies da família Arecaceae e Velloziaceae, bem como indivíduos de diâmetros menores do que $5 \mathrm{~cm}$.

$\mathrm{Na}$ área 1, as dez espécies de maior importância tiveram aumento ou redução na densidade no período de 1990 a 1994, com redução da abundância de algumas espécies em decorrência das queimadas bienais. Em 1990, Vellozia squamata foi a espécie com maior IVI, principalmente, devido à sua dominância, seguida de Ouratea hexasperma, com menor dominância, porém com maior densidade. De 1991 a 1994 Ouratea hexasperma teve maior IVI, devido à sua maior densidade.

Dentre as espécies favorecidas pelas queimadas, Ouratea hexasperma também aparece entre as mais importantes em outros estudos (MIRANDA et al., 2013; HENRIQUES, 2004; ANDRADE et al., 2002; SILVA, 1999) e tem sido associada à áreas com queimadas frequentes no Distrito Federal (FONSECA; SILVA JR., 2004; SAMBUICHI, 1991; SATO, 1996; MOREIRA, 1992; SILVA, 1999). Vellozia squamata ficou em segunda e terceira posição em 1991, 1993, 1994, com menor densidade e maior dominância quando comparada às outras espécies. Em 1992 Styrax ferrugineus foi a segunda espécie com maior IVI; Syagrus flexuosa a terceira e Vellozia squamata a quarta.

Em 2012, após 18 anos de exclusão do fogo, Tachigali subvelutina que estava na oitava posição em 1990, foi a espécie com maior IVI, em razão da dominância elevada em relação às outras espécies. Guapira graciliflora, que estava na $35^{\text {a }}$ posição em 1990, com quatro indivíduos, passou a ser a segunda espécie mais importante, devido ao aumento na 
densidade, frequência e dominância. Myrsine guianensis que também era pouco abundante em 1990, com quatro indivíduos, e estava na 32a posição na classificação pelo IVI, passou a ser a terceira mais importante, também devido ao aumento na densidade, principalmente.

Nesta área, as queimadas frequentes parecem ter favorecido o aumento de densidade de algumas espécies resistentes e a redução na densidade de espécies sensíveis. Tachigali subvelutina parece ser resistente ao fogo, pois sua abundância permaneceu entre 15 e 25 , entre 1990 a 1994, com pouca mortalidade após a queimada de 1992, e aumento da dominância em todo o período de estudo. Myrsine guianensis e Guapira graciliflora parecem ser resilientes, por apresentarem poucos indivíduos durante as queimadas e aumentarem consideravelmente a abundância com o período sem fogo. As queimadas frequentes tendem a reduzir a densidade das plantas lenhosas e, com a abertura da vegetação, tem-se diminuição da competição por luz e nutrientes disponíveis no solo, podendo ter havido o favorecimento de algumas espécies (HOFFMAN, 2002; LIMA et al., 2009).

Na Área 2, as espécies Dalbergia miscolobium, Myrsine guianensis e Guapira noxia se mantiveram entre as três de maior IVI, de 1990 a 2012. Dalbergia miscolobium se manteve na primeira posição até 1991 devido à maior dominância em relação às outras espécies. Myrsine guianensis, que tem sido mencionada como sensível ao distúrbio (SAMBUICHI, 1991), se manteve na primeira posição de 1992 a 1994, em razão da elevada densidade, e, em 2012, em razão da elevada densidade e dominância.

Com relação à distribuição dos indivíduos vivos em classes de altura, observou-se que, nas duas áreas, a distribuição foi similar em todo período do estudo. $\mathrm{Na}$ área 1 , em todos os anos houve maior número de indivíduos na segunda classe de altura (1,2-2,4 m) em comparação à primeira (0-1,2 m), indicando que mesmo com as queimadas algumas espécies da primeira classe de altura não foram atingidas pelo distúrbio, alcançando a próxima classe. Antes da primeira queimada havia um elevado número de indivíduos nas duas primeiras classes (81\% em 1988), com redução em 1990 (68\%) e 1991 (68\%), sugerindo que o fogo afetou os indivíduos menores. Nos anos seguintes, de 1992 a 1994, houve aumento no número de indivíduos nas duas primeiras classes (71\% em 1992, 73\% em 1993, 75\% em 1994), com aumento na primeira classe e redução na segunda classe em 1993 e 1994 (40\% em 1993; 43\% em 1994). Nestes anos alguns indivíduos haviam perdido a parte aérea e rebrotado na base, reduzindo assim o percentual na segunda e terceira classe e aumentando na primeira. 
A diminuição na segunda e terceira classes, por outro lado, pode ter sido em consequência dos danos na parte aérea, com as três queimadas bienais, que tornaram os indivíduos maiores mais vulneráveis, levando à mortalidade, com dano total, ou mortalidade aérea, com danos parciais. O calor desprendido pelo fogo, durante as queimadas, pode causar mais danos nos indivíduos menores, mas aqueles com altura abaixo de dois metros também têm exposição da copa às temperaturas mais elevadas (FIEDLER et al., 2004; MIRANDA et al. 1996), podendo apresentar danos na parte aérea. Assim, alguns indivíduos maiores, que tiveram danos na parte aérea, possivelmente não recuperaram a parte vegetativa tão rapidamente como acontece com alguns indivíduos menores (HOFFMANN; SOLBRIG, 2003; MEDEIROS; MIRANDA, 2005) e apresentaram menor crescimento (SATO et al., 2010), não passando para a classe seguinte de altura.

Além disso, os possíveis danos nas plântulas e indivíduos jovens, relacionados às queimadas, também podem ter limitado o desenvolvimento de alguns indivíduos (SATO et al., 2010) nas menores classes de altura na área com aplicação de fogo. Desta forma, o aumento na primeira classe observada na Área 1 pode ter sido em função das espécies que rebrotaram, dos indivíduos novos (recrutas) que atingiram um metro de altura, após as queimadas bienais, e daqueles que conseguiram sobreviver ao distúrbio, mas tiveram danos na parte aérea, impossibilitando-os de se estabelecer na próxima classe de altura.

$\mathrm{Na}$ Área 2, o aumento no número de indivíduos, na segunda, terceira e quarta classes, de 1988 a 1994, mostra que, com a exclusão do fogo nesta área, alguns indivíduos atingiram alturas maiores e migraram para classes superiores. Na primeira classe, ao longo deste mesmo período, o decréscimo dos indivíduos está, provavelmente, também relacionado ao recrutamento para a classe superior e o aumento, aos novos indivíduos que atingiram a altura mínima de um metro. De 1988 a 1994, e 2012, houve cerca de $80 \%$ dos indivíduos concentrados nas duas primeiras classes de altura (84\% em 1988; 87\% em 1990; 85\% em 1991; 84\% em 1992; 84\% em 1994; 79\% em 2012), ou seja, com altura até 2,4 metros. Essa distribuição dos indivíduos segue o padrão encontrado em outras áreas de Cerrado sentido restrito onde as comunidades são representadas predominantemente por indivíduos com até quatro metros de altura (AQUINO 2004; ASSUNÇÃO; FELFILI, 2004; MARINON JR.; HARIDASAN, 2005).

Em 1988 ainda havia um grande número de indivíduos em processo de regeneração e nos anos seguintes até 2012 algumas espécies alcançaram outras classes superiores em altura. E desta forma, em 2012, nas duas áreas, após o período de exclusão do fogo, houve 
aumento do número de indivíduos em todas as classes, com indivíduos que atingiram classes superiores de altura, ao se comparar com o ano de 1988.

O fogo favoreceu algumas espécies que atingiram alturas maiores, quando comparado à Área 2, que teve a distribuição dos indivíduos em oito classes, enquanto na área com queimadas bienais (Área 1), foram distribuídos em 10 classes. Na área 1, ainda havia um maior percentual de indivíduos na primeira classe (24\% e 17\%) quando comparado com a Área 2 e menor na segunda classe (54\% e 62\%), com maior número de indivíduos em processo de regeneração na área com queimadas (Área 1). Nas duas áreas a maioria dos indivíduos, cerca de $95 \%$, atingiu altura até $3,6 \mathrm{~m}$, poucos atingiram alturas superiores, demonstrando que as espécies são de pequeno porte. Em outro estudo no perímetro urbano de Brasília (DF), em um fragmento de Cerrado sentido restrito com indicativos de distúrbios devido à pressão antrópica do entorno, Assunção e Felfili (2004) também registraram grande percentual de indivíduos jovens, com mais de 59\% dos indivíduos com altura inferior a quatro metros.

As distribuições dos indivíduos vivos em classes de diâmetro nas duas áreas apresentaram curva com padrão de distribuição "j" invertido, comumente encontrado em comunidades em processo de regeneração e recrutamento, onde há maior concentração dos indivíduos na menor classe (ASSUNÇÃO; FELFILI, 2004; ROITMAN et al., 2008; MIRANDA et al., 2013; ALMEIDA et al., 2014). Na Área 1, no período de 1990 a 1994, houve maior concentração (frequência relativa) dos indivíduos nas duas primeiras classes, com algumas variações relacionadas à ocorrência das queimadas prescritas. A segunda queimada, em 1990, facilitou a regeneração e entrada de novos indivíduos em 1991. Geralmente, com a abertura de clareiras após queimadas (MIRANDA; KLINK, 1996b), o sucesso regenerativo está relacionado à capacidade de reprodução vegetativa, de produção de sementes rapidamente, bem como à sobrevivência das plântulas após queimadas recorrentes (HOFFMANN, 1998; WHELAN, 2002; MIRANDA; SATO, 2005).

Desta forma, o aumento na frequência relativa na primeira classe, em 1991, um ano após a segunda queimada, pode estar relacionado ao estímulo, provocado pelo fogo, da floração e produção de sementes (SILVA et al., 2011), ao desenvolvimento de novos indivíduos a partir das sementes que sobreviveram à passagem do fogo (ANDRADE; MIRANDA, 2010), à sobrevivência das plântulas mais resistentes (MIRANDA; SATO, 2005), bem como à capacidade de rebrota de algumas espécies (COUTINHO, 1990). Após a terceira queimada, em 1992, com a mortalidade de algumas plantas, em 1993 houve redução de indivíduos na primeira classe de diâmetro. 
A maior mortalidade após queimada, de forma geral, está associada aos indivíduos nas menores classes de diâmetro, como foi observado em uma área de Cerrado sentido restrito, na Fazenda Água Limpa (DF), por Fiedler et al. (2004), e em área de Campo sujo, na Reserva Ecológica do IBGE (DF) por Medeiros e Miranda (2005). Após 1993, também houve redução na frequência relativa dos indivíduos na segunda classe, possivelmente em consequência de danos causados pelas três queimadas terem fragilizado algumas plantas, levando à mortalidade em anos posteriores. No entanto, em 2012, com a exclusão do fogo houve aumento do número de indivíduos na primeira classe na Área 1 (Frequência relativa de $75 \%$ ) e na Área 2 (Frequência relativa de 68\%), indicando o favorecimento de algumas espécies e que a comunidade ainda está em processo de regeneração.

Resultados semelhantes, com maior concentração de indivíduos $(84,8 \%)$ na primeira classe de diâmetro (até $5 \mathrm{~cm}$ ), também foram observados em uma área de Campo sujo na Reserva Ecológica do IBGE (DF), 23 anos sem queimar (MEDEIROS; MIRANDA, 2005). No entanto, na Reserva da Embrapa Cerrados, possivelmente, distúrbios anteriores ao período do estudo, o pastejo esporádico de gado bovino e a pressão antrópica do entorno, também podem ter influenciado os resultados, principalmente na Área 2. 


\subsection{CONCLUSÕES}

Os monitoramento no período com queimadas bienais de 1988 a 1994 e em 2012 evidenciaram mudanças com relação à composição florística e estrutura da comunidade da vegetação arbóreo-arbustiva.

A comunidade arbóreo-arbustiva se mostrou resistente e resiliente ao fogo, visto que muitas espécies se mantiveram na área durante todo o período de monitoramento, e que a exclusão do distúrbio favoreceu a entrada de espécies, bem como incrementos em densidade e área basal da comunidade.

As duas áreas com distintos históricos de fogo não apresentaram diferenças na riqueza em todo período de estudo. Porém, as duas áreas mostraram diferenças na similaridade florística e na diversidade no período de 1988 a 1994, com queimadas bienais na Área 1, sendo mais diversa na Área 2, em 1988, e na Área 1, em 1994.

A exclusão do fogo por 18 anos favoreceu a similaridade florística entre as duas áreas com distintos históricos de fogo. Por outro lado, proporcionou diferenças na diversidade, onde a Área 1 apresentou maior diversidade em comparação à Área 2.

As duas áreas apresentaram diferenças na densidade e área basal em todo período de estudo, onde as queimadas bienais reduziram a densidade e a área basal e a exclusão do fogo por 18 anos proporcionou o aumento em densidade e área basal.

As duas áreas não mostraram diferenças na distribuição dos indivíduos vivos em classes de altura e diâmetro, em todo período do monitoramento. No entanto, a incidência de queimadas bienais afetou, principalmente, os indivíduos nas menores classes de altura e diâmetro. 


\section{3 - DINÂMICA PÓS-FOGO DA VEGETAÇÃO ARBÓREO-ARBUSTIVA EM UM FRAGMENTO DE CERRADO SENTIDO RESTRITO NO DISTRITO FEDERAL}

\section{RESUMO}

O monitoramento da vegetação arbóreo-arbustiva foi realizado em parcelas permanentes, em duas áreas de um fragmento de Cerrado sentido restrito em Planaltina (DF), em sete ocasiões de 1988 a 2012. Em uma área, chamada Área 1, foram aplicadas queimadas bienais, em agosto de 1988, 1990 e 1992; a outra área, chamada Área 2, foi protegida do fogo até julho de 1994, antes do fogo acidental que atingiu as duas áreas em agosto deste mesmo ano. As duas áreas foram protegidas da ação do fogo de 1995 a 2012. Nos monitoramentos, em junho-julho, antes das queimadas, foram medidas a circunferência, a $30 \mathrm{~cm}$ do solo, e a altura de todos os indivíduos arbóreo-arbustivos que atingiam 1 metro ou mais; em 1988 mediu-se a altura apenas. A dinâmica da comunidade foi analisada de 1991 a 1994, sendo calculados: mortalidade, recrutamento, incremento anual em diâmetro, tempo de meia vida, tempo de duplicação, estabilidade e tempo de substituição. A biomassa aérea foi estimada nas duas áreas, de 1990 a 1994 e em 2012. Nas análises relacionadas à formação de rebrotas foram avaliadas somente aquelas que rebrotaram da base do caule e de estruturas subterrâneas. A formação de grupos funcionais foi analisado em 1994 e 2012, nas duas áreas, pelo método UPGMA. Os grupos foram definidos de acordo com os atributos: síndrome de dispersão, síndrome de polinização, fenologia foliar, forma de vida, tipo de casca e capacidade de rebrotar após distúrbio. As queimadas bienais aumentaram a mortalidade e reduziram o recrutamento de indivíduos. O tempo de meia vida (21 e 50 anos) foi maior que o tempo de duplicação (14 e 11 anos) nas duas áreas. O tempo de substituição na Área 2 (30 anos) foi maior do que na Área 1 (18 anos), indicando que esta área é mais dinâmica. A incidência de queimadas bienais diminuiu a biomassa aérea e favoreceu a reprodução assexuada, com rebrotas basais ou subterrâneas. Houve diferenças na formação dos grupos funcionais nas duas áreas e nas duas épocas. A maior frequência de queimadas bienais, na Área 1 em 1994, reuniu espécies funcionalmente semelhantes, com menor diversidade de atributos. A exclusão do fogo aumentou a biomassa aérea e favoreceu a entrada de algumas espécies e a maior diversidade de atributos funcionais em 2012.

Palavras-chave: mortalidade, recrutamento, reprodução vegetativa, rebrota, biomassa, grupos funcionais 


\subsection{INTRODUÇÃO}

Estudos de dinâmica de plantas avaliam os padrões espaciais de mortalidade, recrutamento, crescimento e regeneração dos indivíduos amostrados em função do tempo, e permitem entender os processos e mecanismos que mantêm a comunidade (SWAINE et al., 1987; AQUINO et al., 2007a; LIBANO; FELFILI, 2006; CARVALHO, et al., 2011; MEWS et al., 2011a; RIBEIRO et al., 2012). O fogo pode causar grande impacto na dinâmica das populações e das comunidades de plantas do Cerrado (HENRIQUES; HAY, 2002; HOFFMANN; MOREIRA, 2002). E, de forma geral, aumenta a mortalidade de árvores (MEDEIROS; MIRANDA, 2005; AQUINO et al., 2007b; RIBEIRO et al., 2012), de plântulas e de indivíduos jovens (HOFFMANN, 1998; MEDEIROS; MIRANDA, 2005), e diminui o recrutamento (HENRIQUES; HAY, 2002; SILVA; ARAÚJO, 2009), a altura da vegetação e ainda a taxa de crescimento de espécies lenhosas no Cerrado (HOFFMANN; MOREIRA, 2002; HENRIQUES; HAY, 2002; MIRANDA; SATO, 2005). Por outro lado, estudos no Cerrado sugerem que a proteção contra o fogo favorece a camada arbórea, oferecendo condições para a regeneração de espécies lenhosas e para o estabelecimento de espécies sensíveis, com aumento na densidade e área basal, taxas de recrutamento maiores que as de mortalidade e baixa rotatividade de plantas (FELFILI et al., 2000; HENRIQUES; HAY, 2002; HOFFMANN; MOREIRA, 2002; LIBANO; FELFILI, 2006). Os estudos de dinâmica ainda são necessários no bioma Cerrado e são úteis para subsidiar iniciativas de conservação, manejo e recuperação de áreas degradadas, bem como ampliar o conhecimento e a utilização de espécies nestas áreas (AQUINO et al., 2007a,b; MEWS et al., 2011a,b).

Grupos funcionais podem ser definidos como o conjunto de espécies que apresentam semelhanças em termos de atributos (MULLER et al., 2007; VALE, 2008; CIANCIARUSO et al., 2009), relacionados às respostas a determinadas condições ambientais ou aos efeitos em processos do ecossistema (MULLER et al., 2007). A diversidade funcional categórica, medida por meio do número de grupos funcionais de uma comunidade, é considerada a medida mais antiga e mais comum de diversidade (CIANCIARUSO et al., 2009). A abordagem funcional permite auxiliar na compreensão do funcionamento e manutenção dos processos ecológicos das comunidades (PETCHEY; GASTON, 2006; DENG et al., 2008; CIANCIARUSO et al., 2009), de forma que, comunidades com alta diversidade funcional devem operar de forma mais eficiente, pois 
maior diversidade funcional implica que uma maior amplitude de recursos está sendo mais bem utilizada (TILMAN, 2001; SOBRAL; CIANCIARUSO, 2012).

As alterações nos grupos funcionais, geralmente, estão relacionadas às variações em certas condições ambientais, como solo, clima, intensidade e frequência de distúrbios (MULLER et al., 2007; SANSEVERO, 2013). Em áreas queimadas frequentemente, o fogo pode agir como um filtro ambiental e selecionar espécies com capacidade de sobreviver e tolerar as condições abióticas derivadas deste distúrbio (CIANCIARUSO et al., 2009; SILVA et al., 2011). O fogo pode reunir espécies com características funcionais semelhantes (SILVA; BATALHA, 2010; CIANCIARUSO et al., 2012) e eliminar espécies com pouca ou nenhuma adaptação a este distúrbio (MEDEIROS; MIRANDA, 2005; SILVA et al., 2011; ZILLI et al., 2014). Assim, as queimadas frequentes podem reduzir a diversidade funcional de comunidades do Cerrado (CIANCIARUSO et al., 2010; SILVA et al., 2011).

Diversos atributos podem ser utilizados na busca de grupos funcionais, no entanto a escolha destes atributos depende das perguntas realizadas (VALE et al., 2011). As síndromes de polinização e dispersão, por exemplo, estão ligadas à habilidade de recolonização diante de distúrbios (CIANCIARUSO et al., 2012; PÉREZHARGUINDEGUY et al., 2013), e a forma de vida pode estar associada ao vigor competitivo e à resposta aos distúrbios (CORNELISSEN et al., 2003; ZILLI et al., 2014). Por outro lado, a espessura e o tipo de casca são fundamentais para conferir resistência ao fogo (HERINGER; JACQUES, 2001), pois a casca protege o câmbio, xilema e floema das altas temperaturas durante queimadas (GUEDES, 1993). Já a habilidade de rebrotar após o fogo está associada ao vigor competitivo e ainda à persistência após distúrbios ambientais (CORNELISSEN et al., 2003; CIANCIARUSO et al., 2012; SILVA, 2013), como queimadas e corte de árvores (CORNELISSEN et al., 2003).

A reprodução assexuada é característica de várias plantas do Cerrado, sendo mencionada como uma das estratégias de resistência ao fogo (MIRANDA; SATO, 2005; SARTORELLI et al., 2007; SALAZAR; GOLDSTEIN, 2014). Em espécies lenhosas, a rebrota após a ocorrência de fogo, pode ocorrer em órgãos aéreos, na base do caule e em estruturas subterrâneas (COUTINHO, 1990; SARTORELLI et al., 2007). As espécies lenhosas podem responder de diferentes formas aos danos causados pelo fogo, e, sendo assim, podem ter danos de acordo com a severidade destes. O dano total ou severo ocorre quando há mortalidade da parte aérea, sem emissão de rebrota, e a morte do indivíduo (MEDEIROS; MIRANDA, 2008; SATO et al., 2010). O dano moderado ou topkill ocorre 
com a morte da parte aérea e rebrotamento na parte basal do tronco ou em órgãos subterrâneos; e o dano leve ocorre quando há ou não perda de ramos, com rebrota aérea (MEDEIROS, 2002; MEDEIROS; MIRANDA, 2008; MOREIRA et al., 2009; SATO et al., 2010). As rebrotas na parte aérea, geralmente, são predominantes em resposta aos eventos do fogo, porém, podem apresentar grande mortalidade, levando à redução no porte e alteração na estrutura dos indivíduos (SATO et al., 2010).

A biomassa aérea desempenha um importante papel no ciclo global de carbono, sendo responsável por uma fração significativa no reservatório de carbono total e reservatório de nutrientes (ALVES et al., 2010). O estoque de biomassa é uma medida imediata da quantidade de carbono que será emitida para a atmosfera quando houver conversão de áreas nativas para outro uso da terra através da queima e decomposição (RIBEIRO et al., 2011). Diversos distúrbios, como fogo, pisoteio por gado, corte seletivo, podem influenciar os resultados estimados para a biomassa aérea (MIRANDA et al., 2011; LOIOLA et al., 2015), e uma vez que, vastas áreas de Cerrado têm sido fortemente afetadas pelo fogo, de origem natural ou antrópica (MIRANDA et al., 2009), e pelo desmatamento, é de extrema importância quantificar a biomassa neste bioma (REZENDE; FELFILI, 2004).

A maioria das pesquisas em áreas de Cerrado contempla a biomassa aérea, no entanto, os estudos de biomassa aérea e subterrânea no Cerrado sentido restrito ainda são escassos (ABDALA et al., 1998; CASTRO; KAUFFMANN, 1998; LILIENFIEN et al., 2001; RIBEIRO et al., 2011), principalmente, devido à grande diversidade de espécies, alta variabilidade entre os indivíduos da mesma espécie e à variação na forma do tronco e galhos (REZENDE et al., 2006). A biomassa pode ser quantificada pelo método direto (destrutivo) ou indireto através de modelos matemáticos (SILVEIRA et al., 2008; VIEIRA et al., 2008). Os modelos alométricos podem ser específicos, para um determinado local, ou gerais, quando estimam a biomassa em diferentes locais (VIEIRA et al., 2008). A quantificação da biomassa pelo método indireto, empregando equações de regressão para volume, com os dados de DAP e altura coletados em inventários (REZENDE et al., 2006; RIBEIRO et al., 2009), pode ser indicada em estudos que necessitem de um monitoramento do crescimento ao longo do tempo. O conhecimento das variações na biomassa é essencial para previsão das emissões de gases de efeito estufa provenientes do uso da terra, além de poder ser usado em planos sustentáveis de recursos florestais (SILVEIRA et al., 2008; ALVES et al., 2010; RIBEIRO et al., 2011; MIRANDA, 2012). 
Neste capítulo fez-se a análise da dinâmica da comunidade arbóreo-arbustiva na área com queimadas bienais (Área 1), e em área protegida contra o fogo (Área 2), no período de 1990 a 1994, bem como a análise das mudanças da biomassa aérea estimada na Área 1 e Área 2, no período de 1990 a 1994, e em 2012. Também foi avaliada a capacidade de rebrotar entre as espécies arbóreo-arbustivas, além da formação de grupos funcionais em 1994 e 2012, nas duas áreas com diferentes históricos de fogo (Área 1, Área 2). Nestas análises procurou-se responder às seguintes questões: 1) A incidência de queimadas bienais altera a dinâmica da comunidade arbóreo-arbustiva, com aumento na mortalidade e redução no recrutamento? 2) A incidência de queimadas bienais diminui a biomassa aérea e a proteção contra o fogo, por 18 anos, aumenta a biomassa aérea? 3) As queimadas bienais aumentam o número de espécies com reprodução vegetativa, com estímulo da formação de rebrotas basais e subterrâneas? 4) A incidência de queimadas modifica os atributos de grupos funcionais de plantas lenhosas?

\subsection{MATERIAL E MÉTODOS}

\subsection{1 Área de estudo}

O estudo foi conduzido em uma área de Cerrado sentido restrito na Reserva Cerrado da Embrapa Cerrados, em Planaltina (DF), com cerca de 2,5 ha (15039.439' S,

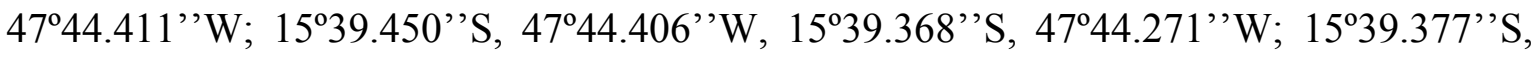
$\left.47^{\circ} 44.265^{\prime} \mathrm{W}\right)$ que foi dividida em duas áreas de cerca de 1,25 ha, com diferentes históricos de fogo (Figura 3.1). Em uma das áreas, chamada neste estudo de Área 1, foram aplicadas queimadas bienais; na outra área, chamada de Área 2, houve proteção contra o fogo até julho de 1994, pois em agosto deste ano um fogo acidental atingiu as duas áreas. 


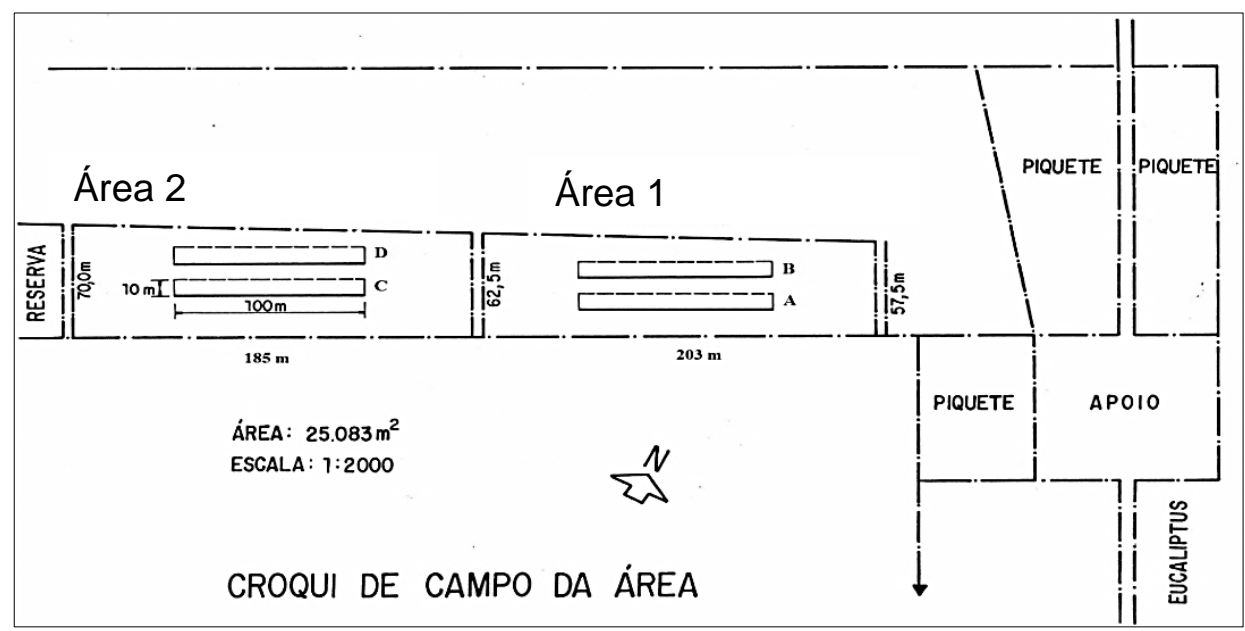

Figura 3.1 - Esquema do posicionamento das transecções em duas áreas de Cerrado sentido restrito na Reserva Cerrado da Embrapa Cerrados, em Planaltina (DF), sendo: Área 1 (transecções A e B), com aplicação de queimadas bienais em agosto de 1988, 1990, e 1992, e proteção do fogo de 1995 a 2012; e Área 2 (transecções C e D), protegida contra a ação do fogo de 1988 a julho de 1994, e de 1995 a 2012. (Coordenadas: 15³9.439' 'S,

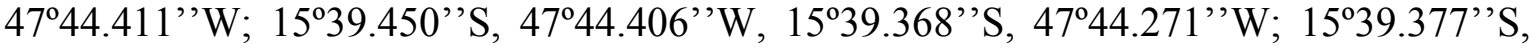
$\left.47^{\circ} 44.265^{\prime}, \mathrm{W}\right)$.

Em cada área foram demarcadas duas transecções com 100 metros de comprimento e 10 metros de largura, e distanciadas 10 metros entre si, totalizando quatro transecções (A, B, C, D) (Figura 3.1). A amostragem da vegetação arbóreo-arbustiva foi feita utilizando-se o método de parcela (MORO; MARTINS, 2011). As parcelas foram demarcadas em maio de 1988 ao longo das transecções nas duas áreas (Área 1, Área 2). Em 1988 foram demarcadas parcelas de 20mx10m, porém em 1990 as parcelas foram remarcadas no mesmo local com medidas de $10 \mathrm{mx} 10 \mathrm{~m}$, para facilitar os trabalhos de campo. Assim, a partir de 1990 o monitoramento foi feito em parcelas de $10 \mathrm{mx} 10 \mathrm{~m}\left(100 \mathrm{~m}^{2}\right)$ nas duas áreas, totalizando 20 parcelas e uma área de amostragem de 0,2 hectares em cada área.

$\mathrm{Na}$ Área 1 (transecções A e B) houve a aplicação de queimadas bienais, que foram adotadas por serem mais comuns na região do Cerrado (COUTINHO, 1982, 1990; SATO, 2003). As queimadas controladas foram aplicadas em 1988, 1990, 1992, sempre no mês de agosto, por ser a época de ocorrência mais frequente de queimadas na região de Brasília (COUTINHO et al., 1982; SATO, 1996). Em 1994 não houve a aplicação da queimada controlada, pois houve a ocorrência de fogo acidental também no mês de agosto (Figura $3.2)$. 


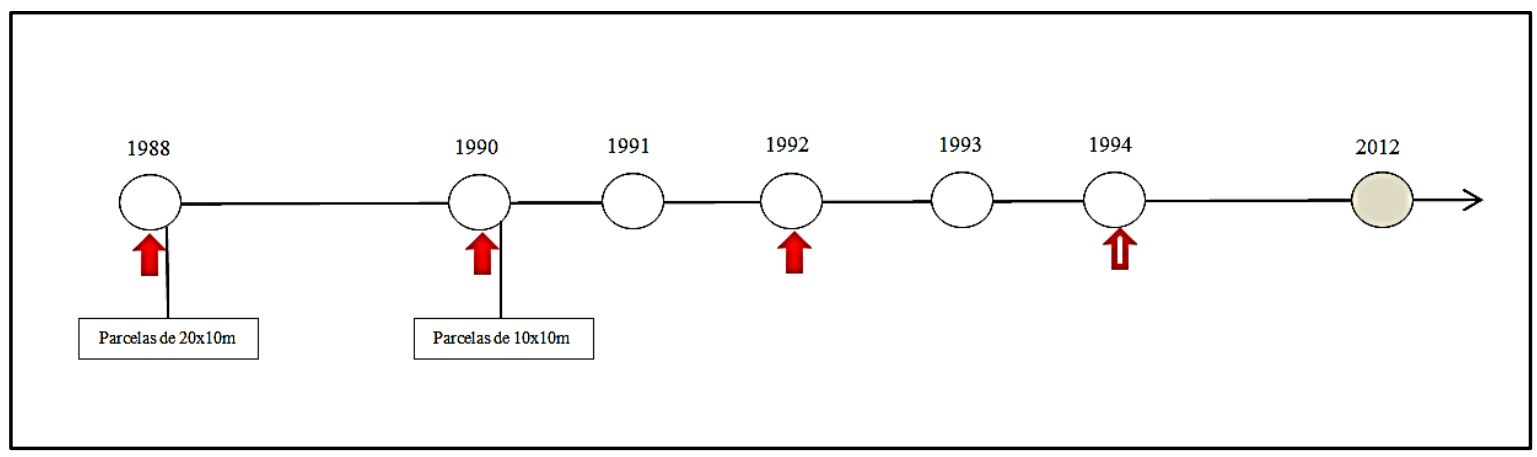

Figura 3.2 - Linha representativa indicando sete ocasiões de monitoramento (1988, 1990, 1991, 1992, 1993, 1994, 2012), o levantamento dos dados, a aplicação de queimadas controladas, e a ocorrência de fogo acidental, em duas áreas de Cerrado sentido restrito, na Reserva Cerrado da Embrapa Cerrados, em Planaltina (DF), sendo: 1 = aplicação de queimada controlada no mês de agosto na Área 1; $\uparrow=$ ocorrência de fogo acidental no mês agosto nas duas áreas (Área 1, Área 2); $\bigcirc=$ levantamento dos dados em junho-julho nas duas áreas (Área 1, Área 2); $\bigcirc=$ levantamento dos dados em setembro nas duas áreas (Área 1, Área 2).

O fogo foi aplicado na Área 1, sempre pela manhã, por uma equipe previamente preparada de funcionários da Embrapa Cerrados. Antes de cada queimada foram construídos aceiros em volta desta área. A Área 2 (transecções C e D), foi protegida contra a ação do fogo até julho de 1994, pois em agosto de 1994 o fogo acidental também atingiu esta área (Figura 3.2). As duas áreas foram protegidas contra a ação do fogo de 1995 a 2012. O monitoramento da vegetação teve início em 1988 e foi realizado sempre antes do fogo, em sete ocasiões (1988, 1990, 1991, 1992, 1993, 1994, 2012). De 1988 a 1994 foram feitos levantamentos nos meses de junho-julho, e em 2012, em setembro, ainda no período seco.

Nos levantamentos, todas as espécies arbóreo-arbustivas, que atingiam o critério de inclusão de um metro ou mais de altura (MUELLER-DOMBOIS; ELLEMBERG, 1974) foram numeradas com placas de alumínio e mensuradas. Anotaram-se, para cada indivíduo, a altura e a circunferência, bem como o nome das espécies ocorrentes em cada parcela. Também foram incluídos os indivíduos mortos que "estavam em pé” e as espécies da família Arecaceae e de Vellozia sp que atingiam a altura mínima de um metro. Em 2012, nem todas as placas antigas (colocadas de 1988 a 1994) permaneciam nos indivíduos. Desta forma, mantiveram-se as placas antigas, continuando a numeração a partir de 3000 para os indivíduos que não possuíam placas, pois em 1994 o emplacamento havia parado em número próximo de 2900.

A altura total foi medida com o uso de uma régua graduada de $3 \mathrm{~m}$, sendo que as alturas acima de três metros foram estimadas visualmente, tomando como base a régua; a 
circunferência foi medida com fita métrica. Em 1988 foram anotados somente os dados referentes à altura dos indivíduos. Nos anos de 1990 a 1994 e em 2012 foram feitas medidas de altura e circunferência. As medidas de circunferência foram tomadas a $30 \mathrm{~cm}$ do solo, altura considerada padrão em vários estudos no Cerrado (FELFILI; SILVA JR., 1988; FELFILI et al., 2005; ALMEIDA et al., 2014). Os dados de diâmetro foram calculados posteriormente.

Quando o exemplar de uma espécie se ramificava abaixo do nível do solo e cada eixo emergia separado dos demais, cada eixo foi considerado um indivíduo distinto (MORO; MARTINS, 2011). Nos casos em que os indivíduos, dentro do critério de inclusão adotado, apresentavam bifurcações abaixo de $30 \mathrm{~cm}$, mediram-se todos os ramos e, posteriormente, foi calculado o diâmetro quadrático das ramificações, conforme sugerido por Scolforo e Thiersch (2004) pela fórmula: $d=\sqrt{\left(d_{1}\right)^{2}+\left(d_{2}\right)^{2}}$; sendo: $d=$ diâmetro quadrático; $d^{1}=$ diâmetro do ramo $1 ; d^{2}=$ diâmetro do ramo 2 .

Durante o monitoramento da vegetação arbórea de 1990 a 1994, nas duas áreas, foram incluídos os indivíduos novos que alcançavam a altura de 1 metro, sendo, assim, considerados recrutas. Estes também foram medidos quanto à altura e circunferência e marcados com placas de alumínio na sequência da numeração do primeiro inventário em 1988. Também foram anotadas, ao longo do tempo (1990 a 1994), as plantas que morriam e aquelas que rebrotavam. Considerou-se rebrota os indivíduos que tiveram morte aérea, onde a copa e caule foram queimados, e que apresentavam brotações na parte basal ou subterrânea das plantas. Os indivíduos com mortalidade aérea ou destruição total do caule, quando não apresentavam rebrota, foram considerados mortos.

Nos levantamentos florísticos de 1988 até 1994 foram feitas coletas de material botânico fértil e depósito no Herbário da Universidade de Brasília (UB), Herbário do Jardim Botânico de Brasília - Ezechias Paulo Heringer (HEPH), Herbário da Reserva Ecológica do IBGE e da Embrapa Recursos Genéticos e Biotecnologia - CENARGEN (CEN), em Brasília, Distrito Federal. As espécies férteis coletadas de 2012 a 2015 foram depositadas no Herbário da Universidade de Brasília (UB).

\subsubsection{Análise dos dados}

A dinâmica da comunidade foi analisada com base nas taxas de mortalidade, recrutamento e crescimento. Com os dados obtidos nos monitoramentos para cada ano (de 
1991 a 1994) e para cada área (fogo, conservação) foram calculados: número de indivíduos de cada amostragem, indivíduos que ingressaram e indivíduos que morreram. Assim, foram obtidos os parâmetros de dinâmica: mortalidade (m), recrutamento (r) e incremento diamétrico (medida de crescimento). Também foram obtidos valores de meia vida, tempo de duplicação, estabilidade e tempo de substituição.

As taxas anuais de mortalidade e recrutamento foram calculadas de acordo com as fórmulas (em \%.ano ${ }^{-1}$ ) (SHEIL et al., 1995): $m=\left\{1-\left[\left(\mathrm{N}_{0}-\mathrm{N}_{\mathrm{M}}\right) / \mathrm{N}_{0}\right]^{1 / t}\right\} \times 100 ; r=\{1-[1-$ $\left.\left(\mathrm{N}_{\mathrm{R}} / \mathrm{N}_{\mathrm{t}}\right)\right]^{1 / t}$ \}x100. Sendo: $m=$ mortalidade; $r=$ recrutamento; $\mathrm{N}_{0}=$ número de indivíduos na primeira medição; $\mathrm{N}_{\mathrm{M}}=$ número de indivíduos que morreram; $\mathrm{N}_{\mathrm{t}}=$ número de indivíduos na última medição; $\mathrm{t}=$ tempo (número de anos) entre as medições. Através do valor da taxa anual de mortalidade, foi calculada a meia-vida $(\mathrm{t} 1 / 2)$, ou seja, o intervalo de tempo para que o número de indivíduos da comunidade seja reduzido pela metade, mantida constante a atual taxa de mortalidade. Foi empregada a seguinte fórmula (KORNING; BALSLEV, 1994): $t^{1} 12=[\ln (0.5)] /(0.01 m)$. O tempo de duplicação $\left(t_{2}\right)$, ou seja, o tempo necessário para duplicar a população inicial foi calculado de acordo a fórmula (KORNING; BALSLEV, 1994): $t_{2}=(\ln (2)) /(0.01 r)$. A estabilidade (E) é a diferença entre $t_{2}$ e $t^{1} / 2$, e o tempo de substituição (turnover time), é calculado pela média dos valores de duplicação $\left(\mathrm{t}_{2}\right)$ e meia vida (t¹²) (KORNING; BALSLEV, 1994).

Como medida de crescimento para a comunidade foi calculado o incremento

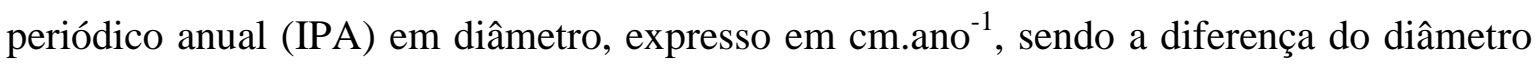
do indivíduo na última e na primeira medição dividido pelo tempo transcorrido em anos (ENCINAS et al., 2005; SCOLFORO; MELLO, 2006). Com isso foram determinados a média e o desvio padrão. As taxas de recrutamento, mortalidade e os demais parâmetros foram analisados nas duas áreas (Área1, Área 2) para o período de 1991 a 1994.

Quanto às análises da variação da biomassa aérea ao longo do tempo, optou-se pelo método indireto. A biomassa acima do solo das espécies arbóreo-arbustivas foi baseada em avaliações de DAP e H, estimada por meio de equação, nas duas áreas (1 e 2) em 6 anos (1990 a 1994 e 2012). Foi avaliada apenas a biomassa aérea seca por meio da equação proposta por Rezende et al. (2006) para o Cerrado sentido restrito: $\mathrm{B}=0,49129+$ 0,02912* $\mathrm{Db}^{2} * \mathrm{Ht}$. Onde: $\mathrm{B}=$ biomassa $\left(\mathrm{kg}^{2}\right.$ ind $\left.^{-1}\right), \mathrm{Db}=$ diâmetro da base $(\mathrm{cm})$ e $\mathrm{Ht}=$ altura (m). Os dados originais foram transformados com a função $\log _{10}$, a fim de atender aos pressupostos de normalidade e homocedasticidade. O teste $\mathrm{t}$ de Student e o teste de $\mathrm{t}$ pareado foram úteis para avaliar possíveis diferenças significativas $(\alpha=0,05)$ nas duas áreas 
(fogo, conservação) entre os anos de amostragem (ZAR, 2009). Foi utilizado o programa PAST versão 2.15 (HAMMER et al., 2001) e o software Excel 2010 do Windows.

Nas análises relacionadas à formação de rebrotas foram avaliadas somente aquelas espécies que rebrotaram da base do caule e de estruturas subterrâneas. Na Área 1, após a incidência da terceira queimada, as rebrotas subterrâneas ou da parte basal das plantas foram formadas após a morte aérea (topkill) de 1993 até 1994. Mas, também houve desenvolvimento de rebrotas na Área 2. E, desta forma, foi calculado o número de rebrotas total em todos os anos, nas duas áreas. Os resultados foram comparados, ao longo do tempo e nas duas áreas (Área 1, Área 2).

A formação de grupos funcionais foi avaliada de acordo com atributos relacionados ao distúrbio pelo fogo, em 1994 (após 3 queimadas bienais) e em 2012 (após 18 anos de proteção contra o fogo), tanto na Área 1 quanto na Área 2. Os grupos foram definidos de acordo com os seguintes atributos funcionais: síndrome de dispersão (zoocórica, anemocórica, autocórica ou barocórica), síndrome de polinização (zoófila, anemófila), fenologia foliar (decídua, sempre-verde), forma de vida (arbusto, árvore), tipo de casca (liso, não liso) e capacidade de rebrotar após distúrbio (sim, não).

Quanto à síndrome de dispersão, as espécies foram classificadas em: autocóricas ou barocóricas - dispersam sementes ou frutos por gravidade ou apresentam mecanismos de auto-dispersão, como a deiscência explosiva; anemocóricas - sementes ou frutos apresentam mecanismos que facilitam a dispersão pelo vento; zoocóricas - diásporos com características relacionadas à dispersão por animais (PIJL, 1982). Quanto à polinização as espécies foram classificadas em anemofilia e zoofilia. $\mathrm{Na}$ anemofilia foram incluídas plantas polinizadas pelo vento; na zoofilia foram incluídas plantas polinizadas por insetos (abelhas, moscas, mariposas, borboletas e outros pequenos insetos), morcegos e pássaros (BAWA, 1990).

Com relação à deciduidade, as plantas decíduas são aquelas que perdem as folhas na estação seca, mas também foram incluídas as espécies brevidecíduas, pois perdem suas folhas em um período curto de tempo. As espécies classificadas como sempre-verde são aquelas que retêm as folhas durante o todo ano, incluindo, as semidecíduas, pois não perdem todas as folhas ao longo do ano (VALE et al., 2013).

A casca foi classificada de acordo com o aspecto da camada mais externa, sendo considerada casca lisa aquela com superfície sem cicatrizes foliares, deiscências, fendas, fissuras, lenticelas ou rugosidades, e não lisa (ou de aspecto áspero), aquela onde a superfície apresenta cicatrizes foliares, deiscências, fendas, fissuras, lenticelas ou 
rugosidades irregulares, sem um padrão ou de forma desorganizada (SILVA JR., 2005). Quanto à capacidade de rebrotar, as espécies que rebrotaram na base do caule ou em estruturas subterrâneas durante o monitoramento de 1988 a 1994 foram classificadas como capazes de rebrotar. Com relação à forma de vida, as espécies foram classificadas em árvore ou arbusto.

Os atributos foram avaliados de acordo com os dados obtidos na literatura (dispersão, polinização, deciduidade, forma de vida, tipo de casca), principalmente, e em observações de campo (capacidade de rebrotar, forma de vida e tipo de casca). Foram incluídas as espécies com abundância maior ou igual a 5 indivíduos de acordo com os levantamentos florísticos de 1994 e 2012. Esse critério de inclusão foi baseado em outros trabalhos que sugerem que as espécies com número reduzido de indivíduos apresentam pouca ou nenhuma influência sobre os resultados (VALE, 2008; ARAÚJO et al., 2010).

Os grupos funcionais foram analisados por meio de técnicas de agrupamento, seguindo a metodologia usada por Vale et al. (2011). Foram feitas matrizes de presença/ausência de acordo com os atributos qualitativos de cada espécie. Foi calculado o índice similaridade de Jaccard entre as espécies e com esses coeficientes foi construído um dendrograma usando-se o método de agrupamento de Ligação Média Não Ponderada UPGMA (VALENTIN, 2000). O coeficiente de correlação cofenética foi utilizado como medida de concordância entre os agrupamentos obtidos e a matriz de distância original (VALENTIN, 2000; VALE et al., 2011). Foi usado o programa FITOPAC (SHEPHERD, 2010) na análise dos dados.

\subsection{RESULTADOS}

\section{Parâmetros de dinâmica}

Na Área 1, durante o período de 1991 a 1994, com as queimadas de 1988, 1990 e 1992, foram registrados 42 indivíduos mortos e 67 recrutas. O maior número de mortos foi registrado no período 1992-1993, com 23 indivíduos, com maior taxa de mortalidade $\left(4,7 . \%\right.$.ano $\left.{ }^{-1}\right)$ e menor de recrutamento $\left(1,9 . \%\right.$. ano $\left.{ }^{-1}\right)$ do que a do período anterior (10 $\%$. ano $^{-1}$ ). O maior número de recrutas foi observado de 1991-1992, dois anos após a segunda queimada, que ocorreu em 1990. Na Área 2, registrou-se menor número de indivíduos mortos (33) e maior número de recrutas (167), com menores taxas de mortalidade e maiores de recrutamento do que na Área 1, no mesmo período (Tabela 3.1). 
Tabela 3.1 - Características da vegetação arbóreo-arbustiva de Cerrado sentido restrito em duas áreas (Área 1, Área 2), com diferentes históricos de fogo, no período de 1991-1994, onde: Área 1, com queimadas bienais em 1988, 1990 e 1992; Área 2, protegida contra o fogo de 1988 a julho de 1994.

\begin{tabular}{ccccc}
\hline Período & \multicolumn{5}{c}{ Área 1 } \\
\cline { 2 - 5 } & $\begin{array}{c}\text { Número de } \\
\text { mortos }\end{array}$ & $\begin{array}{c}\text { Mortalidade } \\
\left(\% \cdot \text { ano }^{-1}\right)\end{array}$ & $\begin{array}{c}\text { Número de } \\
\text { recrutas }\end{array}$ & $\begin{array}{c}\text { Recrutamento } \\
\left(\% \cdot \text { ano }^{-1}\right)\end{array}$ \\
\hline $1991-1992$ & 5 & 1,1 & 49 & 10 \\
$1992-1993$ & 23 & 4,7 & 9 & 1,9 \\
$1993-1994$ & 14 & 2,9 & 9 & 1,9 \\
\hline & \multicolumn{5}{c}{ Área 2 } \\
\cline { 2 - 6 } & Número de & Mortalidade $\left.^{-1}\right)$ & Número de & Recrutamento \\
& mortos & $(\% \cdot$ ano & recrutas & $\left(\%\right.$. ano $\left.{ }^{-1}\right)$ \\
\hline $1991-1992$ & 19 & 2,4 & 41 & 5,0 \\
$1992-1993$ & 5 & 0,6 & 103 & 11,3 \\
$1993-1994$ & 9 & 1,0 & 23 & 2,5 \\
\hline
\end{tabular}

Na Área 1, entre 1991 e 1994, a taxa de mortalidade foi de 3,2\%.ano ${ }^{-1}$ e na Área 2, a taxa de mortalidade foi de 1,4\%.ano-1 (Tabela 3.2). Na Área 1, os 42 indivíduos que morreram estavam distribuídos em 20 espécies, 50\% delas com um indivíduo apenas, e Guapira graciliflora e Guapira noxia com o maior número de mortos, 6 (14\%) e 7 (17\%), respectivamente. Na Área 2, das 33 plantas que morreram no período de 1991 a 1994, 12\% pertenciam à Aegiphila verticillata, 9\% a Connarus suberosus e 9\% a Kielmeyera coriacea. A taxa de recrutamento $\left(4,9\right.$ e $6,4 \%$.ano- $\left.^{-1}\right)$ excedeu à taxa de mortalidade nas duas áreas, no período de 1991-1994 (Tabela 3.2). Na Área 1, dos 67 indivíduos recrutados, distribuídos em 26 espécies, $15 \%$ pertenciam à Guapira graciliflora e $15 \%$ à Styrax ferrugineus. Já na Área 2, dos 167 indivíduos recrutados, distribuídos em 36 espécies, $27 \%$ pertenciam a Myrsine guianensis; 5\% a Dalbergia miscolobium e 5\% a Styrax ferrugineus. 
Tabela 3.2 - Parâmetros de dinâmica da vegetação arbóreo-arbustiva de Cerrado sentido restrito, em duas áreas (Área 1, Área 2), com diferentes históricos de fogo, no período de 1991 a 1994, sendo: Área 1, com queimadas bienais em 1988, 1990 e 1992; e Área 2, protegida contra a ação do fogo de 1988 a julho de 1994.

\begin{tabular}{|c|c|c|c|c|}
\hline \multirow[t]{2}{*}{ Parâmetros } & \multicolumn{2}{|c|}{ Área 1} & \multicolumn{2}{|c|}{ Área 2} \\
\hline & 1991 & $1994 *$ & 1991 & $1994 *$ \\
\hline N. de indivíduos vivos & 446 & 471 & 790 & 924 \\
\hline N. de ind. Mortos & & 42 & & 33 \\
\hline N. de recrutas & & 67 & & 167 \\
\hline Taxa de mortalidade $\left(\%\right.$. ano $\left.^{-1}\right)$ & & 3,2 & & 1,4 \\
\hline Taxa de recrutamento $\left(\%\right.$. ano $\left.^{-1}\right)$ & & 4,9 & & 6,4 \\
\hline Tempo de meia vida (anos) & & 22 & & 50 \\
\hline Tempo de duplicação (anos) & & 14 & & 11 \\
\hline Tempo de substituição (anos) & & 18 & & 30 \\
\hline Estabilidade (anos) & & 8 & & 39 \\
\hline
\end{tabular}

*Obs.: o levantamento dos dados em 1994 ocorreu antes do fogo acidental que atingiu as duas áreas em agosto.

O tempo de meia vida (22 e 50 anos) foi maior que o tempo de duplicação (14 e 11 anos) nas duas áreas. O tempo de substituição na Área 2 (30 anos) foi maior do que na Área 1 (18 anos), indicando que a Área 1, com fogo, é mais dinâmica. A estabilidade foi menor na Área 1 (8 anos) do que na Área 2 (39 anos) (Tabela 3.2). Considerando todos os indivíduos vivos de todas as espécies, no período de 3 anos, o incremento periódico anual médio em diâmetro, da comunidade na Área 1 foi de $0,11 \mathrm{~cm} \cdot$ ano $^{-1}$ (desvio padrão=0,37), e na Área 2 foi de $0,14 \mathrm{~cm} \cdot$ ano $^{-1}$ (desvio padrão=0,26).

\section{Biomassa aérea}

$\mathrm{Na}$ Área 1, a biomassa aérea estimada variou de 8,5 Mg.ha ${ }^{-1}$ a 9,5 Mg.ha-1, e na Área 2, de 9,4 Mg.ha ${ }^{-1}$ a 11,7 Mg.ha ${ }^{-1}$, no período de 1990 a 1994, antes do fogo acidental que atingiu as duas áreas em agosto de 1994. Após 18 anos sem fogo, a biomassa aérea estimada foi maior na Área 1 (30,8 Mg.ha- $\left.{ }^{1}\right)$ do que na Área 2 (22,9 Mg.ha ${ }^{-1}$ ) (Tabela 3.3). 


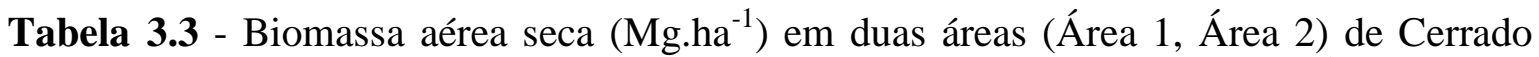
sentido restrito, com diferentes históricos de fogo, em 6 ocasiões, onde: Área 1, com aplicação de queimadas bienais em 1988, 1990 e 1992, e proteção contra o fogo de 1995 a 2012; Área 2, protegida da ação do fogo no período de 1988 a julho de 1994, e de 1995 a 2012.

\begin{tabular}{lllllll}
\hline \multirow{2}{*}{ ÁREA } & \multicolumn{7}{c}{ Ano } \\
\cline { 2 - 7 } & 1990 & 1991 & 1992 & 1993 & $1994^{*}$ & 2012 \\
\hline Área 1 & 8,5 & 9,2 & 9,5 & 9,8 & 9,5 & 30,8 \\
Área 2 & 9,4 & 9,8 & 10,8 & 11,9 & 11,7 & 22,9 \\
\hline
\end{tabular}

*Obs.: o levantamento dos dados, em 1994, foi feito antes do fogo acidental que atingiu as duas áreas em agosto.

O fogo não alterou a biomassa/parcela no período com queimadas bienais, de 1990 a 1994, pois não foram observadas diferenças significativas ( $p>0,05$ ), pelo teste de $t$, nos resultados entre a Área 1 e a Área 2, antes do fogo acidental de agosto de 1994. No entanto, o fogo alterou de forma significativa (teste de $\mathrm{t}$ pareado, $\mathrm{p}<0,05$ ) a biomassa aérea média entre as duas áreas neste mesmo período. $\mathrm{O}$ fogo também influenciou a biomassa total de forma significativa $(\mathrm{p}<0,05)$, sendo que a Área 1 apresentou resultados inferiores aos da Área 2 (Tabela 3.3). Após 18 anos sem queimar, em 2012 as análises mostraram diferenças significativas pelo teste de $\mathrm{t}(\mathrm{p}<0,05)$ da biomassa aérea por parcela entre a Área 1 e a Área 2; a Área 1 apresentou valores superiores aos da Área 2. O teste de t pareado também mostrou diferenças significativas entre a biomassa por parcela observada em 1994 e em 2012, nas duas áreas, mostrando que o período sem fogo favoreceu o seu aumento.

\section{Rebrotas}

Na Área 1, um total de 121 indivíduos, distribuídos em 36 espécies, rebrotaram, sendo 111 em 1993 e 10 em 1994. Na Área 2, 13 espécies, de 14 indivíduos, rebrotaram em 1993 e quatro em 1994 (Tabela 3.4). Os indivíduos que rebrotaram tiveram danos na parte aérea (topkill) com as queimadas e rebrotaram em anos subsequentes. Assim, na Área 1, dos indivíduos que perderam a parte aérea e apresentaram rebrotas basais em 1993, no ano anterior, ou seja, em 1992, 108 tinham altura entre 1 a $2 \mathrm{~m}$, dois com altura de 0,5 m, e dois já haviam perdido a parte aérea. Com relação ao diâmetro, o fogo também afetou os indivíduos menores, sendo que 105 tinham diâmetro entre 1,1 a 5,1cm, quatro entre 5,9 a 7,9, e dois já tinham perdido a parte aérea em 1992. Os indivíduos que rebrotaram em 1994 tinham altura de 0,75 a 1,65 m e diâmetro de 3,2 a 5,9 cm, em 1993. Na Área 2, os indivíduos que rebrotaram em 1993, tinham altura entre 0,7 a 1,6 m e diâmetro de 1,9 a 8,3 cm em 1992. Já daqueles que rebrotaram em 1994, somente um ainda estava vivo em 1993, com altura variando de 1,2 a 2,2 m, os outros três haviam perdido a parte aérea. 
Tabela 3.4 - Número de indivíduos com rebrotas, por espécie, em duas áreas de Cerrado sentido restrito, com diferentes históricos de queimadas, sendo: Área 1, com aplicação de queimadas bienais em 1988, 1990 e 1992; Área 2, com proteção do fogo de 1988 a julho de 1994.

\begin{tabular}{|c|c|c|c|c|c|}
\hline \multirow[t]{2}{*}{ Espécies } & \multicolumn{2}{|c|}{1993} & \multicolumn{2}{|c|}{ 1994* } & \multirow[t]{2}{*}{ Total } \\
\hline & Área 1 & Área 2 & Área 1 & Área 2 & \\
\hline Aegiphila verticillata & 9 & 2 & 3 & 1 & 15 \\
\hline Annona monticola & 2 & & & & 2 \\
\hline Aspidosperma macrocarpum & 3 & & & & 3 \\
\hline Aspidosperma tomentosum & 2 & & & & 2 \\
\hline Brosimum gaudichaudii & 1 & & & & 1 \\
\hline Caryocar brasiliense & 4 & & & & 4 \\
\hline Casearia sylvestris & 1 & 1 & & & 2 \\
\hline Connarus suberosus & 1 & 2 & & & 3 \\
\hline Dalbergia miscolobium & 4 & 3 & 1 & & 8 \\
\hline Dimorphandra mollis & 3 & & & 1 & 4 \\
\hline Erythroxylum campestre & 1 & & & & 1 \\
\hline Erythroxylum deciduum & 1 & & & & 1 \\
\hline Erythroxylum suberosum & 2 & 1 & 1 & & 4 \\
\hline Guapira graciliflora & 8 & & & 1 & 9 \\
\hline Guapira noxia & 1 & 1 & & & 2 \\
\hline Handroanthus ochraceus & 2 & & 1 & & 3 \\
\hline Hymenaea stigonocarpa & & 1 & & & 1 \\
\hline Kielmeyera coriacea & 1 & & 1 & & 2 \\
\hline Leptolobium dasycarpum & 2 & & & & 2 \\
\hline Machaerium opacum & 5 & 1 & 1 & & 7 \\
\hline Mimosa claussenii & 2 & & & & 2 \\
\hline Myrsine guianensis & 13 & & & & 13 \\
\hline Neea theifera & 2 & 1 & & & 3 \\
\hline Ouratea hexasperma & 1 & 1 & 1 & & 3 \\
\hline Piptocarpha rotundifolia & 1 & & & & 1 \\
\hline Plathymenia reticulata & 4 & & & & 4 \\
\hline Plenckia populnea & 4 & & & & 4 \\
\hline Psidium laruotteanum & 2 & & & & 2 \\
\hline Qualea multiflora & 1 & & & & 1 \\
\hline Roupala montana & 2 & & & & 2 \\
\hline Schefflera macrocarpa & 2 & & & & 2 \\
\hline Strychnos pseudoquina & 1 & & & & 1 \\
\hline Stryphnodendron adstringens & 2 & & & 1 & 3 \\
\hline Styrax ferrugineus & 16 & & 1 & & 17 \\
\hline Tachigali vulgaris & 3 & & & & 3 \\
\hline Tocoyena formosa & 1 & & & & 1 \\
\hline Vochysia elliptica & 1 & & & & 1 \\
\hline Total Geral & 111 & 14 & 10 & 4 & 139 \\
\hline
\end{tabular}

*Obs.: o levantamento dos dados, em 1994, foi feito antes do fogo acidental que atingiu as duas áreas em agosto. 


\section{Grupos funcionais}

Nas análises de formação de grupos funcionais foram avaliadas 52 espécies, mas este número variou em cada ano. Em 1994 foram 384 indivíduos distribuídos em 32 espécies, na Área 1, com três queimadas bienais, e 852 indivíduos, em 34 espécies, na Área 2. Em 2012, com 18 anos de proteção contra o fogo, foram 1231 indivíduos, distribuídos em 47 espécies na Área 1, e 1152 indivíduos, em 37 espécies na Área 2.

Na Tabela 3.5 encontram-se os atributos funcionais para cada espécie. Os atributos foram definidos de acordo com observações de campo e com a consulta às seguintes bibliografias: 1-Amaral et al. (2012); 2-Barbosa Filho e Araújo (2009); 3-Carmo (2014); 4Carvalho (2005); 5-Cavalcante et al. (2009); 6-Gottsgerger (1989); 7-Gúzman e Morales (2007); 8-Kuhlmann (2012); 9-Lenza e Klink (2006); 10-Lorenzi et al. (2006); 11-Marquis et al. (2001); 12-Martins e Batalha (2001); 13-Mendonça et al. (2008); 14-Mohr e Lenza (2011); 15-Oliveira (2012); 16-Passos (2009); 17-Pires (2011); 18-Pilon et al. (2015); 19Prado Jr. et al. (2012); 20-Reis et al. (2012); 21-Silva Jr. (2005); 22-Silva Jr. e Pereira (2009); 23-Silva et al. (2012); 24-Silva et al. (2009); 25-Silva (2014); 26-Stefanello et al. (2009) e 27-Takahashi (2010).

Tabela 3.5 - Lista de espécies arbóreo-arbustivas de Cerrado sentido restrito utilizadas nas análises de formação de grupos funcionais em duas áreas (Área 1 e Área 2), em dois anos do monitoramento (1994 e 2012), com respectivos atributos de classificação, de acordo com a numeração da literatura mencionada acima e observações de campo.

\begin{tabular}{|c|c|c|c|c|c|c|c|c|}
\hline Espécie & $\begin{array}{c}\text { Nome } \\
\text { abreviado }\end{array}$ & $\begin{array}{c}\text { Tipo } \\
\text { de } \\
\text { casca }\end{array}$ & $\begin{array}{c}\text { Capacidade } \\
\text { para } \\
\text { rebrotar }\end{array}$ & $\begin{array}{c}\text { Hábito de } \\
\text { crescimento }\end{array}$ & Polinização & Dispersão & Deciduidade & Referências \\
\hline $\begin{array}{l}\text { Aegiphila } \\
\text { verticillata }\end{array}$ & AEGVERT & $\begin{array}{l}\text { não } \\
\text { lisa }\end{array}$ & $\operatorname{sim}$ & árvore & zoófila & zoocórica & decídua & 21 \\
\hline $\begin{array}{l}\text { Annona } \\
\text { crassiflora }\end{array}$ & ANNCR & $\begin{array}{l}\text { não } \\
\text { lisa }\end{array}$ & não & árvore & zoófila & $\begin{array}{c}\text { autocórica } \\
\text { ou } \\
\text { barocórica e } \\
\text { zoocórica }\end{array}$ & decídua & $12,20,21$ \\
\hline $\begin{array}{l}\text { Annona } \\
\text { monticola }\end{array}$ & ANNMO & lisa & $\operatorname{sim}$ & arbusto & zoófila & zoocórica & decídua & $5,6,7,16$ \\
\hline $\begin{array}{l}\text { Annona } \\
\text { tomentosa }\end{array}$ & ANNTO & lisa & não & arbusto & zoófila & zoocórica & decídua & $5,6,7,16$ \\
\hline $\begin{array}{l}\text { Aspidosperma } \\
\text { macrocarpum }\end{array}$ & ASPIMA & $\begin{array}{l}\text { não } \\
\text { lisa }\end{array}$ & $\operatorname{sim}$ & árvore & zoófila & anemocórica & decídua & $\begin{array}{l}12,14,20, \\
21\end{array}$ \\
\hline $\begin{array}{l}\text { Aspidosperma } \\
\text { tomentosum }\end{array}$ & ASPITO & $\begin{array}{l}\text { não } \\
\text { lisa }\end{array}$ & $\operatorname{sim}$ & árvore & zoófila & anemocórica & decídua & $12,20,21$ \\
\hline $\begin{array}{l}\text { Bauhinia } \\
\text { dumosa }\end{array}$ & BAUDU & lisa & não & arbusto & zoófila & $\begin{array}{c}\text { autocórica } \\
\text { ou } \\
\text { barocórica }\end{array}$ & decídua & $1,7,14$ \\
\hline $\begin{array}{l}\text { Byrsonima } \\
\text { coccolobifolia }\end{array}$ & BYRCO & $\begin{array}{l}\text { não } \\
\text { lisa }\end{array}$ & não & árvore & zoófila & zoocórica & decídua & $\begin{array}{l}8,9,14,20, \\
21\end{array}$ \\
\hline $\begin{array}{l}\text { Byrsonima } \\
\text { verbascifolia }\end{array}$ & BYRVE & $\begin{array}{l}\text { não } \\
\text { lisa }\end{array}$ & não & árvore & zoófila & zoocórica & decídua & $\begin{array}{l}8, \quad 12, \quad 14, \\
20,21\end{array}$ \\
\hline $\begin{array}{l}\text { Caryocar } \\
\text { brasiliense }\end{array}$ & CARYBR & $\begin{array}{l}\text { não } \\
\text { lisa }\end{array}$ & $\operatorname{sim}$ & árvore & zoófila & zoocórica & decídua & $8,12,20,21$ \\
\hline $\begin{array}{l}\text { Chomelia } \\
\text { ribesioides }\end{array}$ & CHOMRI & $\begin{array}{l}\text { não } \\
\text { lisa }\end{array}$ & não & arbusto & zoófila & zoocórica & decídua & $8,11,12$ \\
\hline
\end{tabular}




\begin{tabular}{|c|c|c|c|c|c|c|c|c|}
\hline Espécie & $\begin{array}{c}\text { Nome } \\
\text { abreviado }\end{array}$ & $\begin{array}{c}\text { Tipo } \\
\text { de } \\
\text { casca }\end{array}$ & $\begin{array}{c}\text { Capacidade } \\
\text { para } \\
\text { rebrotar }\end{array}$ & $\begin{array}{c}\text { Hábito de } \\
\text { crescimento }\end{array}$ & Polinização & Dispersão & Deciduidade & Referências \\
\hline $\begin{array}{l}\text { Connarus } \\
\text { suberosus }\end{array}$ & CONNSU & $\begin{array}{l}\text { não } \\
\text { lisa }\end{array}$ & $\operatorname{sim}$ & árvore & zoófila & zoocórica & decídua & $12,20,21$ \\
\hline Cordiera sessilis & CORDSE & $\begin{array}{l}\text { não } \\
\text { lisa }\end{array}$ & não & arbusto & zoófila & zoocórica & $\begin{array}{l}\text { sempre- } \\
\text { verde }\end{array}$ & $2,8,10$ \\
\hline $\begin{array}{l}\text { Dalbergia } \\
\text { miscolobium }\end{array}$ & DALBMI & $\begin{array}{l}\text { não } \\
\text { lisa }\end{array}$ & $\operatorname{sim}$ & árvore & zoófila & anemocórica & decídua & $2,4,12,21$ \\
\hline $\begin{array}{l}\text { Dimorphandra } \\
\text { mollis }\end{array}$ & DIMOMO & $\begin{array}{l}\text { não } \\
\text { lisa }\end{array}$ & Sim & árvore & zoófila & zoocórica & decídua & $12,20,21$ \\
\hline $\begin{array}{l}\text { Diospyros } \\
\text { burchellii }\end{array}$ & DIOSBUR & $\begin{array}{l}\text { não } \\
\text { lisa }\end{array}$ & não & árvore & zoófila & zoocórica & decídua & 8 \\
\hline $\begin{array}{l}\text { Eremanthus } \\
\text { goyazensis }\end{array}$ & EREMGOY & $\begin{array}{l}\text { não } \\
\text { lisa }\end{array}$ & não & arbusto & zoófila & anemocoria & $\begin{array}{l}\text { sempre- } \\
\text { verde }\end{array}$ & $\begin{array}{l}3,4,13,20, \\
26\end{array}$ \\
\hline $\begin{array}{l}\text { Eriotheca } \\
\text { pubescens }\end{array}$ & ERIOPU & $\begin{array}{l}\text { não } \\
\text { lisa }\end{array}$ & não & árvore & zoófila & anemocórica & decídua & 21,27 \\
\hline $\begin{array}{l}\text { Erythroxylum } \\
\text { deciduum }\end{array}$ & ERYTDE & $\begin{array}{l}\text { não } \\
\text { lisa }\end{array}$ & $\operatorname{sim}$ & árvore & zoófila & zoocórica & decídua & $1,11,21$ \\
\hline $\begin{array}{l}\text { Erythroxylum } \\
\text { suberosum }\end{array}$ & ERYTSU & $\begin{array}{l}\text { não } \\
\text { lisa }\end{array}$ & $\operatorname{sim}$ & árvore & zoófila & zoocórica & decídua & $8,12,20,21$ \\
\hline $\begin{array}{l}\text { Guapira } \\
\text { graciliflora }\end{array}$ & GUAPGR & lisa & $\operatorname{sim}$ & árvore & zoófila & zoocórica & decídua & 8,21 \\
\hline Guapira noxia & GUAPNO & $\begin{array}{l}\text { não } \\
\text { lisa }\end{array}$ & $\operatorname{sim}$ & árvore & zoófila & zoocórica & decídua & 12,21 \\
\hline $\begin{array}{l}\text { Handroanthus } \\
\text { ochraceus }\end{array}$ & HANDOC & $\begin{array}{l}\text { não } \\
\text { lisa }\end{array}$ & $\operatorname{sim}$ & árvore & zoófila & anemocórica & decídua & $\begin{array}{l}12,20,21, \\
24\end{array}$ \\
\hline $\begin{array}{l}\text { Heteropterys } \\
\text { byrsonimifolia }\end{array}$ & HETEBY & $\begin{array}{l}\text { não } \\
\text { lisa }\end{array}$ & não & árvore & zoófila & anemocórica & decídua & $1,14,21$ \\
\hline $\begin{array}{l}\text { Hymenaea } \\
\text { stigonocarpa }\end{array}$ & HYMEST & $\begin{array}{l}\text { não } \\
\text { lisa }\end{array}$ & $\operatorname{sim}$ & árvore & zoófila & zoocórica & decídua & $12,20,21$ \\
\hline $\begin{array}{l}\text { Kielmeyera } \\
\text { coriacea }\end{array}$ & KIELCO & $\begin{array}{l}\text { não } \\
\text { lisa }\end{array}$ & sim & árvore & zoófila & anemocórica & decídua & $\begin{array}{l}11,12,20, \\
21\end{array}$ \\
\hline $\begin{array}{l}\text { Leptolobium } \\
\text { dasycarpum }\end{array}$ & LEPTDA & $\begin{array}{l}\text { não } \\
\text { lisa }\end{array}$ & sim & árvore & zoófila & anemocórica & decídua & 21 \\
\hline $\begin{array}{l}\text { Machaerium } \\
\text { opacum }\end{array}$ & MACHOP & $\begin{array}{l}\text { não } \\
\text { lisa }\end{array}$ & sim & árvore & zoófila & anemocórica & $\begin{array}{l}\text { sempre- } \\
\text { verde }\end{array}$ & 15,21 \\
\hline $\begin{array}{l}\text { Maprounea } \\
\text { guianensis }\end{array}$ & MAPRGU & $\begin{array}{l}\text { não } \\
\text { lisa }\end{array}$ & não & árvore & anemofilia & zoocórica & decídua & $8,11,22$ \\
\hline $\begin{array}{l}\text { Miconia } \\
\text { albicans }\end{array}$ & MICOAL & $\begin{array}{l}\text { não } \\
\text { lisa }\end{array}$ & não & arbusto & zoófila & zoocórica & $\begin{array}{l}\text { sempre- } \\
\text { verde }\end{array}$ & $8,9,12,18$ \\
\hline $\begin{array}{l}\text { Miconia } \\
\text { burchellii }\end{array}$ & MICOBU & $\begin{array}{l}\text { não } \\
\text { lisa }\end{array}$ & não & árvore & zoófila & zoocórica & $\begin{array}{l}\text { sempre- } \\
\text { verde }\end{array}$ & 21 \\
\hline Miconia fallax & MICOFA & $\begin{array}{l}\text { não } \\
\text { lisa }\end{array}$ & não & arbusto & zoófila & zoocórica & $\begin{array}{l}\text { sempre- } \\
\text { verde }\end{array}$ & $8,9,12$ \\
\hline $\begin{array}{l}\text { Mimosa } \\
\text { claussenii }\end{array}$ & MIMOCL & $\begin{array}{l}\text { não } \\
\text { lisa }\end{array}$ & $\operatorname{sim}$ & árvore & zoófila & $\begin{array}{c}\text { anemocórica } \\
\text { e zoocórica }\end{array}$ & decídua & 21 \\
\hline $\begin{array}{l}\text { Myrsine } \\
\text { guianensis }\end{array}$ & MYRSGU & $\begin{array}{l}\text { não } \\
\text { lisa }\end{array}$ & $\operatorname{sim}$ & árvore & zoófila & zoocórica & $\begin{array}{l}\text { sempre- } \\
\text { verde }\end{array}$ & 9,21 \\
\hline Neea theifera & Neeath & $\begin{array}{l}\text { não } \\
\text { lisa }\end{array}$ & $\operatorname{sim}$ & árvore & zoófila & zoocórica & decídua & 12,21 \\
\hline $\begin{array}{l}\text { Ouratea } \\
\text { hexasperma }\end{array}$ & OURAHE & $\begin{array}{l}\text { não } \\
\text { lisa }\end{array}$ & $\operatorname{sim}$ & árvore & zoófila & zoocórica & $\begin{array}{l}\text { sempre- } \\
\text { verde }\end{array}$ & $\begin{array}{l}8, \quad 14,20, \\
21,24\end{array}$ \\
\hline $\begin{array}{l}\text { Palicourea } \\
\text { rigida }\end{array}$ & PALIRI & $\begin{array}{l}\text { não } \\
\text { lisa }\end{array}$ & não & árvore & zoófila & zoocórica & $\begin{array}{l}\text { sempre- } \\
\text { verde }\end{array}$ & $12,21,24$ \\
\hline $\begin{array}{l}\text { Piptocarpha } \\
\text { rotundifolia }\end{array}$ & PIPTRO & $\begin{array}{l}\text { não } \\
\text { lisa }\end{array}$ & $\operatorname{sim}$ & árvore & zoófila & anemocórica & decídua & $12,20,21$ \\
\hline $\begin{array}{l}\text { Plenckia } \\
\text { populnea }\end{array}$ & PLENPO & $\begin{array}{l}\text { não } \\
\text { lisa }\end{array}$ & $\operatorname{sim}$ & árvore & zoófila & anemocórica & $\begin{array}{l}\text { sempre- } \\
\text { verde }\end{array}$ & $12,20,21$ \\
\hline $\begin{array}{l}\text { Pouteria } \\
\text { ramiflora }\end{array}$ & POUTRA & $\begin{array}{l}\text { não } \\
\text { lisa }\end{array}$ & nao & árvore & zoófila & zoocórica & decídua & $8,12,20,21$ \\
\hline Protium ovatum & PROTOV & lisa & não & arbusto & zoófila & zoocórica & $\begin{array}{l}\text { sempre- } \\
\text { verde }\end{array}$ & $2,8,25$ \\
\hline $\begin{array}{l}\text { Psidium } \\
\text { laruotteanum }\end{array}$ & PSIDLA & $\begin{array}{l}\text { não } \\
\text { lisa }\end{array}$ & $\operatorname{sim}$ & árvore & zoófila & zoocórica & decídua & $8,12,21$ \\
\hline $\begin{array}{l}\text { Qualea } \\
\text { parviflora }\end{array}$ & QUALPA & $\begin{array}{l}\text { não } \\
\text { lisa }\end{array}$ & não & árvore & zoófila & anemocórica & decídua & $\begin{array}{l}12,14,20, \\
21,24\end{array}$ \\
\hline $\begin{array}{l}\text { Roupala } \\
\text { montana }\end{array}$ & ROUPMO & $\begin{array}{l}\text { não } \\
\text { lisa }\end{array}$ & $\operatorname{sim}$ & árvore & zoófila & anemocórica & $\begin{array}{l}\text { sempre- } \\
\text { verde }\end{array}$ & $12,21,27$ \\
\hline $\begin{array}{l}\text { Schefflera } \\
\text { macrocarpa }\end{array}$ & SHEFMA & $\begin{array}{l}\text { não } \\
\text { lisa }\end{array}$ & $\operatorname{sim}$ & árvore & zoófila & zoocórica & $\begin{array}{l}\text { sempre- } \\
\text { verde }\end{array}$ & 15,21 \\
\hline
\end{tabular}




\begin{tabular}{|c|c|c|c|c|c|c|c|c|}
\hline Espécie & $\begin{array}{c}\text { Nome } \\
\text { abreviado }\end{array}$ & $\begin{array}{c}\text { Tipo } \\
\text { de } \\
\text { casca }\end{array}$ & $\begin{array}{c}\text { Capacidade } \\
\text { para } \\
\text { rebrotar } \\
\end{array}$ & $\begin{array}{l}\text { Hábito de } \\
\text { crescimento }\end{array}$ & Polinização & Dispersão & Deciduidade & Referências \\
\hline $\begin{array}{l}\text { Stryphnodendron } \\
\text { adstringens }\end{array}$ & STRYAD & $\begin{array}{l}\text { não } \\
\text { lisa }\end{array}$ & $\operatorname{sim}$ & árvore & zoófila & $\begin{array}{c}\text { Autocórica } \\
\text { ou } \\
\text { barocórica e } \\
\text { zoocórica }\end{array}$ & decídua & $9,21,25$ \\
\hline $\begin{array}{l}\text { Strychnos } \\
\text { pseudoquina }\end{array}$ & STRYPS & $\begin{array}{l}\text { não } \\
\text { lisa }\end{array}$ & $\operatorname{sim}$ & árvore & zoófila & zoocórica & decídua & $\begin{array}{l}12,20,21, \\
14\end{array}$ \\
\hline $\begin{array}{l}\text { Styrax } \\
\text { ferrugineus }\end{array}$ & STYRFE & $\begin{array}{l}\text { não } \\
\text { lisa }\end{array}$ & $\operatorname{sim}$ & árvore & zoófila & zoocórica & $\begin{array}{l}\text { sempre- } \\
\text { verde }\end{array}$ & 12,21 \\
\hline $\begin{array}{l}\text { Tachigali } \\
\text { subvelutina }\end{array}$ & TACHISU & $\begin{array}{l}\text { não } \\
\text { lisa }\end{array}$ & $\operatorname{sim}$ & árvore & zoófila & anemocórica & $\begin{array}{l}\text { sempre- } \\
\text { verde }\end{array}$ & $12,20,21$ \\
\hline $\begin{array}{l}\text { Tocoyena } \\
\text { formosa }\end{array}$ & TOCOFO & $\begin{array}{l}\text { não } \\
\text { lisa }\end{array}$ & $\operatorname{sim}$ & árvore & zoófila & zoocórica & decídua & $8,12,21$ \\
\hline $\begin{array}{l}\text { Vochysia } \\
\text { elliptica }\end{array}$ & VOCHEL & $\begin{array}{l}\text { não } \\
\text { lisa }\end{array}$ & $\operatorname{sim}$ & árvore & zoófila & anemocórica & $\begin{array}{l}\text { sempre- } \\
\text { verde }\end{array}$ & 21,25 \\
\hline $\begin{array}{l}\text { Zeyheria } \\
\text { montana }\end{array}$ & ZEYHMO & $\begin{array}{l}\text { não } \\
\text { lisa }\end{array}$ & não & árvore & zoófila & anemocórica & $\begin{array}{l}\text { sempre- } \\
\text { verde }\end{array}$ & 21 \\
\hline
\end{tabular}

Na Área 1, em 1994, formaram-se quatro grupos, com 32 espécies arbóreas, todos com casca não lisa e polinização zoófila (Figura 3.3). Primeiro, as espécies foram separadas pelo tipo de dispersão, zoocórica (59\%) e anemocórica (35\%), e, de acordo com aquelas que rebrotaram (91\%) e aquelas que não rebrotaram (9\%). Dentro dos grupos com zoocoria $(\mathrm{A}, \mathrm{B}, \mathrm{C})$ temos as espécies que não rebrotaram $(\mathrm{C})$ e aquelas que tiveram capacidade de rebrotar (A, B). O Grupo D, com espécies anemocóricas, é composto de espécies que rebrotam e decíduas. Assim, na Área 1, os grupos formados apresentaram as seguintes características: Grupo A (13 espécies, 113 indivíduos) - espécies com dispersão zoocórica na maioria (1 espécie com zoocoria e autocoria), árvores, caule não liso (1 liso), com capacidade para rebrotar, decíduas, e com polinização zoófila; Grupo B (4 espécies, 101 indivíduos) - espécies com dispersão zoocórica, árvores, caule não liso, com capacidade para rebrotar, sempre-verdes, e com polinização zoófila; Grupo C (3 espécies, 29 indivíduos) - espécies com dispersão zoocórica na maioria (1 autocórica e zoocórica), árvores, caule não liso, não rebrotaram, decíduas, e com polinização zoófila; Grupo D (12 espécies, 141 indivíduos) - espécies com dispersão anemocórica, árvores, caule não liso, com capacidade para rebrotar, decíduas e sempre-verdes, e com polinização zoófila. 


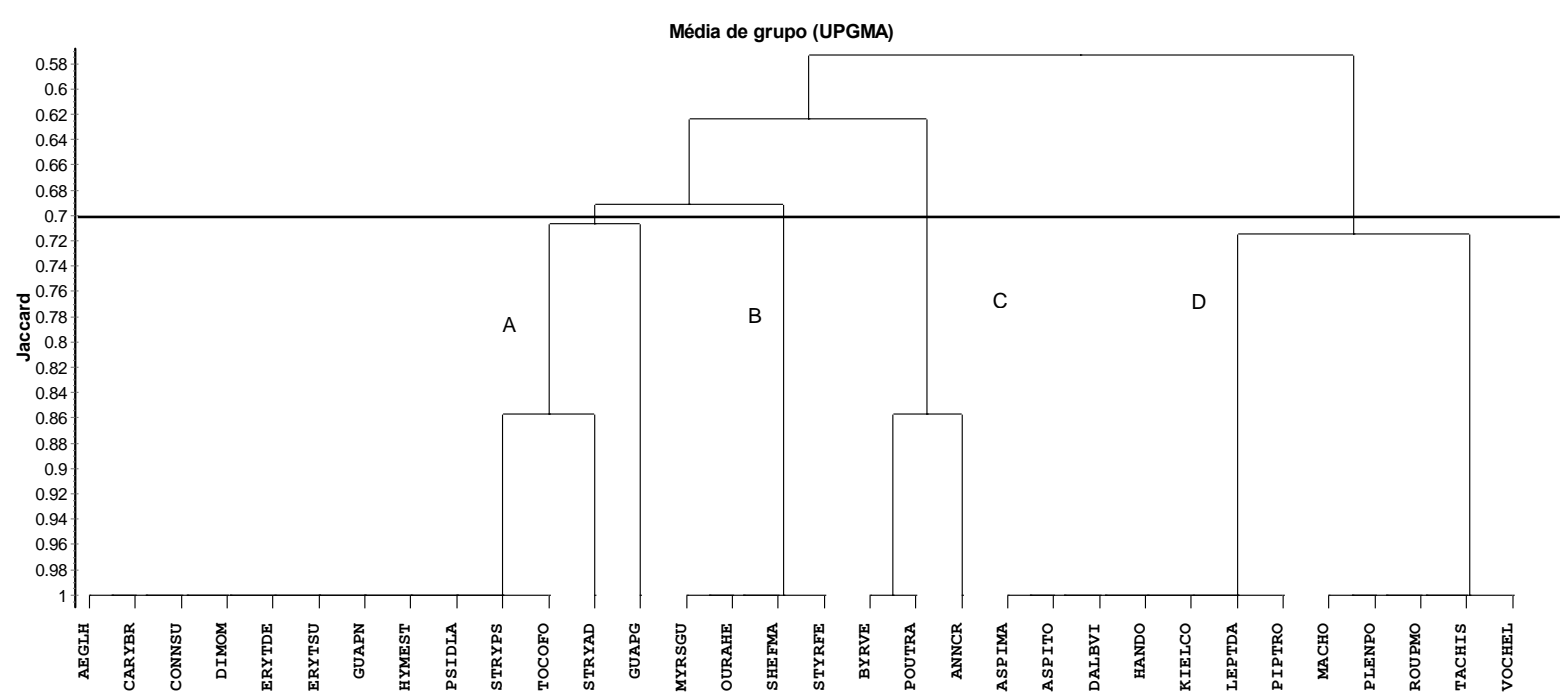

Figura 3.3 - Dendrograma de similaridade pelo método UPGMA, utilizando o índice de Jaccard, mostrando a formação de grupos funcionais para espécies arbóreo-arbustivas de Cerrado sentido restrito em 1994 na Área 1, com queimadas bienais em agosto de 1988, 1990 e 1992. Correlação Cofenética $=0,86$.

Na Área 2, em 1994, formaram-se quatro grupos, tendo uma espécie que ficou isolada (Protium ovatum). Foram incluídas 34 espécies, entre árvores e arbustos de caule com casca lisa e não lisa (maioria) e todos com polinização zoófila (Figura 3.4). Os grupos foram divididos primeiramente pelo tipo de dispersão zoocórica $(60 \%)$ e anemocórica (37\%), com espécies com capacidade para rebrotar (79\%) e sem capacidade para rebrotar (21\%). Assim, os grupos A, C e E incluem espécies zoocóricas, e os grupos B e D anemocóricas. O Grupo A inclui espécies com capacidade para rebrotar, principalmente, e uma que não rebrota. O Grupo B com espécies que rebrotam e os grupos C, D e E, com espécies que não rebrotam. Assim, formaram-se grupos com as seguintes características: Grupo A (17 espécies, 526 indivíduos) - espécies com dispersão zoocórica na maioria (uma espécie com zoocoria e autocoria), árvores, caule com casca não lisa na maioria (uma com caule liso), espécies com capacidade para rebrotar (uma não rebrotou), decíduas e sempre-verdes, e com polinização zoofilia; Grupo B (11 espécies, 266 indivíduos) espécies com dispersão anemocórica, árvores, caule não liso, com capacidade para rebrotar, decíduas e sempre-verdes, e com polinização zoófila; Grupo C (3 espécies, 36 indivíduos) - espécies com dispersão zoocórica, árvore e arbusto, com caule não liso, não rebrotaram, decíduas, e com polinização zoófila; Grupo D (2 espécies, 15 indivíduos) espécies com dispersão anemocórica, árvore e arbusto, com caule não liso, não rebrotaram, sempre-verdes, e com polinização zoófila; Grupo E (1 espécie isolada, 9 indivíduos ) - com 
dispersão zoocórica, arbusto, caule liso, não rebrotou, sempre-verde, e com polinização zoófila.

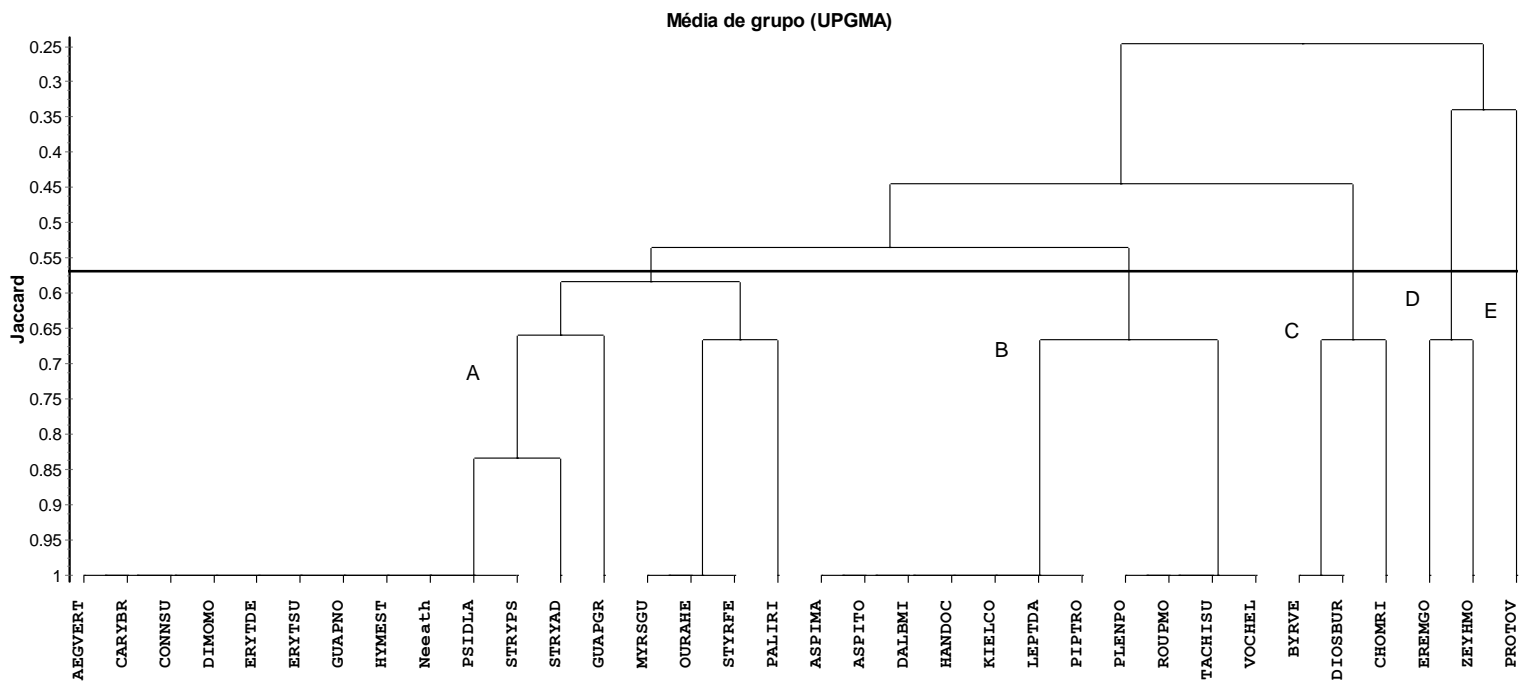

Figura 3.4 - Dendrograma de similaridade pelo método UPGMA, utilizando o índice de Jaccard, mostrando a formação de grupos funcionais para espécies arbóreo-arbustivas de Cerrado sentido restrito em 1994 na Área 2, protegida contra o fogo no período de 1988 a julho de 1994. Correlação Cofenética= 0,87.

Em 2012, na Área 1, formaram-se cinco grupos, com 47 espécies, entre árvores e arbustos, de caule liso ou não liso, polinização zoófila e anemófila (Figura 3.5). Os grupos foram divididos, principalmente, pelas espécies com capacidade de rebrotar (64\%) e aquelas que não rebrotam (36\%), e tipo de casca lisa (11\%) e não lisa (89\%). Assim, os grupos A e B incluíram espécies que rebrotam, e os grupos $\mathrm{C}, \mathrm{D}$ e $\mathrm{E}$, espécies que não rebrotam, sendo que o Grupo E inclui uma espécie que não rebrota, mas todas espécies são decíduas com casca lisa. Assim, formaram-se grupos com as seguintes características: Grupo A (20 espécies, 528 indivíduos) - espécies com capacidade para rebrotar, árvores, com casca não lisa na maioria (uma casca lisa), decíduas, zoofilia, zoocoria (uma com barocoria ou autocoria e zoocoria), anemocoria; Grupo B (9 espécies, 421 indivíduos) espécies com capacidade para rebrotar, árvores, casca não lisa, sempre-verdes, zoofilia, anemocoria e zoocoria; Grupo C (8 espécies, 72 indivíduos) - espécies que não rebrotaram, árvores, casca não lisa, decídua, zoofilia (1 com anemofilia), zoocoria (uma com autocoria ou barocoria e zoocoria), anemocoria; Grupo D (7 espécies, 127 indivíduos) - espécies que não rebrotaram, arbustos (maioria) e árvores (2), casca não lisa (maioria) e casca lisa (1), sempre-verdes (maioria) e decídua (1), zoofilia, zoocoria; Grupo E (3 espécies, 83 
indivíduos) - espécies que não rebrotaram (1 rebrotou), arbustos, casca lisa, decíduas, zoofilia, zoocoria (2) e uma com autocoria ou barocoria.

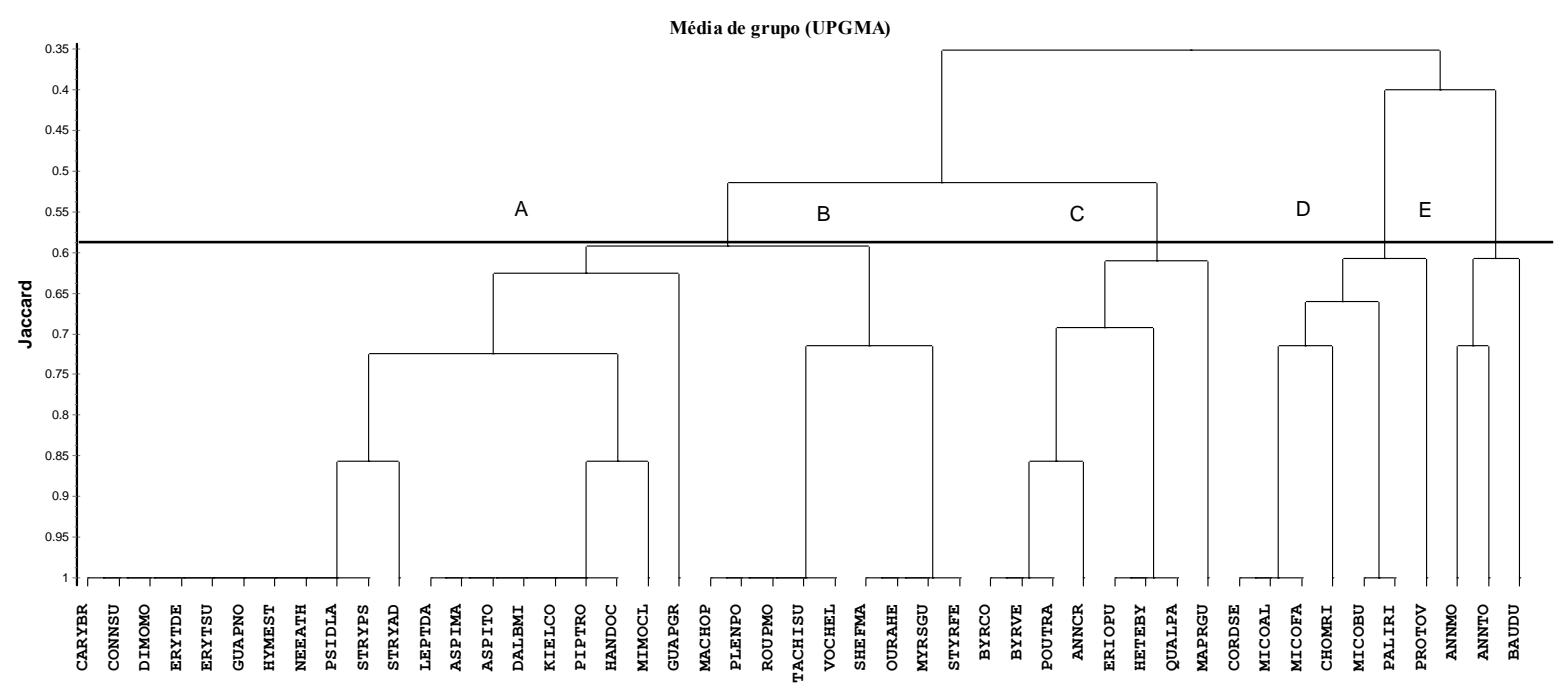

Figura 3.5 - Dendrograma de similaridade pelo método UPGMA, utilizando o índice de Jaccard, mostrando a formação de grupos funcionais para espécies arbóreo-arbustivas de Cerrado sentido restrito em 2012 na Área 1, com queimadas bienais em agosto de 1988, 1990 e 1992, fogo acidental em agosto de 1994, e com exclusão do fogo de 1995 a 2012. Correlação Cofenética $=0,84$.

Em 2012, na Área 2, formaram-se cinco grupos, com 37 espécies, entre árvores e arbustos e polinização zoófila (Figura 3.6). A característica mais marcante foi o tipo de casca (lisa e não lisa). A deciduidade também foi outra característica importante. Assim, os grupos foram divididos inicialmente pelo tipo de casca. Os grupos A, B e C incluíram espécies com casca não lisa, decíduas (A) e sempre-verdes (B, C). Os grupos D e E incluíram espécies com casca lisa, decíduas (E) e decíduas e sempre-verdes (D). Os grupos A, B e D incluíram espécies com dois tipos de dispersão. Assim, formaram-se grupos com as seguintes características: Grupo A (20 espécies, 382 indivíduos) - com espécies com casca não lisa, árvores, decíduas, com capacidade para rebrotar na maioria (2 não rebrotam), zoofilia, anemocoria, zoocoria (uma com autocoria ou barocoria e zoocoria); Grupo B (8 espécies, 477 indivíduos) - com espécies com casca não lisa, árvores, sempreverdes, com capacidade para rebrotar, zoofilia, zoocoria e anemocoria; Grupo C (4 espécies, 120 indivíduos) - com espécies com casca não lisa, árvores e arbustos, sempreverdes, não rebrotam, zoofilia, zoocoria; Grupo D (3 espécies, 108 indivíduos) - com espécies com casca lisa, arbustos, decíduas e sempre-verdes, não rebrotam, zoofilia, 
autocoria ou barocoria e zoocoria; Grupo E (2 espécies, 65 indivíduos): espécies com casca lisa, arbusto e árvore, decíduas, com capacidade para rebrotar, zoofilia, zoocoria.

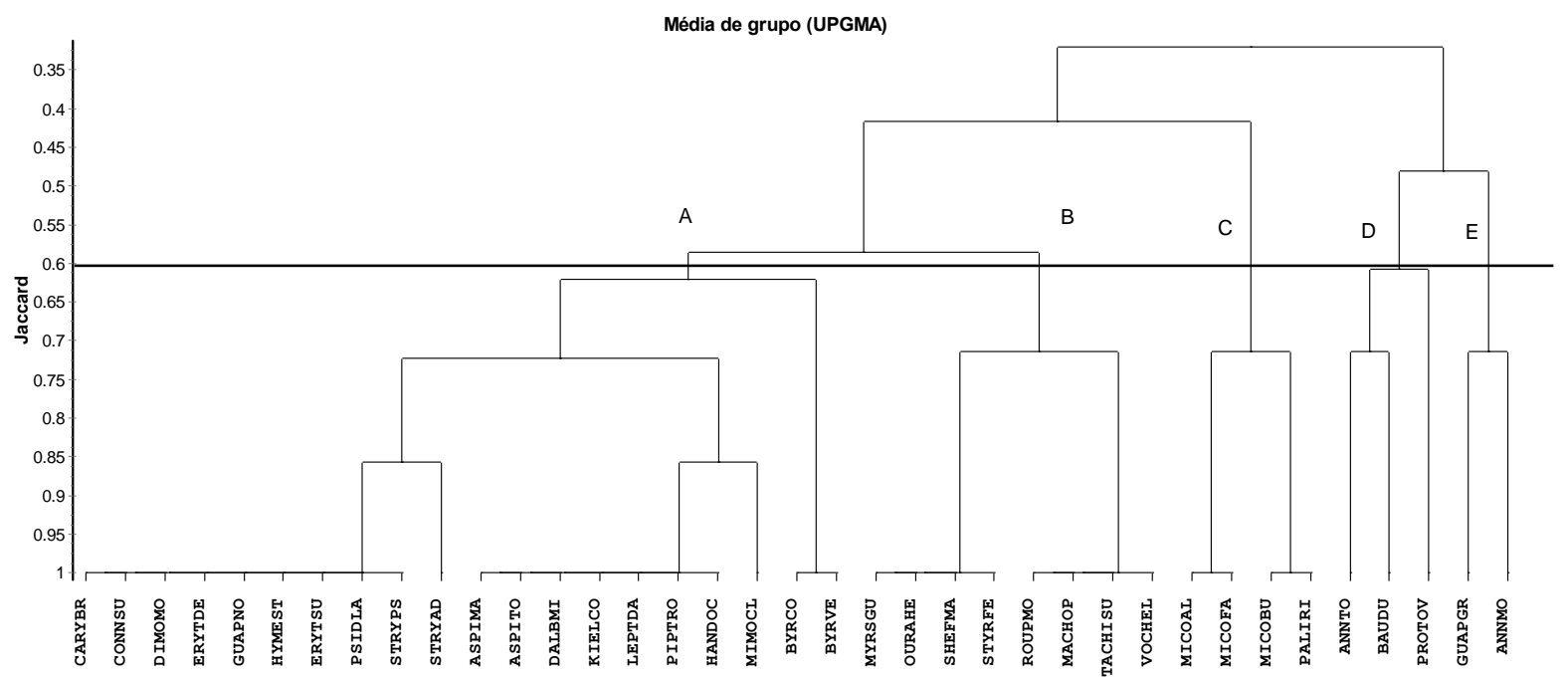

Figura 3.6 - Dendrograma de similaridade pelo método UPGMA, utilizando o índice de Jaccard, mostrando a formação de grupos funcionais para espécies arbóreo-arbustivas de Cerrado sentido restrito em 2012, na Área 2, protegida contra o fogo no período de 1988 a julho de 1994, fogo acidental em agosto de 1994, e com exclusão do fogo de 1995 a 2012. Correlação Cofenética $=0,87$.

\subsection{DISCUSSÃO}

\section{Parâmetros de dinâmica}

Os resultados mostraram diferenças nas taxas de dinâmica entre as duas áreas estudadas. De acordo com a constatação, foi observado que na Área 1, com três queimadas bienais aplicadas em agosto, a taxa de recrutamento de 4,9\%.ano ${ }^{-1}$ foi inferior à da Área 2 ,

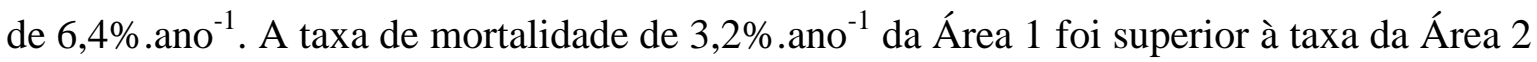
$\left(1,4 \%\right.$. ano $\left.{ }^{-1}\right)$, que foi protegida contra o fogo no mesmo período, indicando a influência da ação do fogo nas taxas de recrutamento e de mortalidade. Portanto, os resultados alcançados estão de acordo com a literatura, onde, em geral, as taxas de recrutamento são maiores que as de mortalidade em áreas protegidas (HENRIQUES; HAY, 2002; ROITMANN et al., 2008; SOUZA, 2010).

Resultado próximo ao encontrado na Área 2 foi observado em área de Cerrado sentido restrito protegida do fogo por 18 anos, na Reserva Ecológica do IBGE (DF) no Distrito Federal, por Henriques e Hay (2002) que obtiveram taxa de mortalidade de 1,34\%.ano ${ }^{-1}$. Por outro lado, nesta mesma área da Reserva Ecológica do IBGE (DF), após 
19 anos do primeiro inventário em 1991, e com registro de um incêndio, Souza (2010) observou taxa de mortalidade de $3,5 \%$ ano $^{-1}$ e de recrutamento de $4,45 \%$ ano $^{-1}$, que estão mais similares aos observados na Área 1 da Embrapa Cerrados, em Planaltina (DF). Já, em outro estudo em Cerrado sentido restrito, em Mato Grosso, Ribeiro et al. (2012) relacionaram a taxa de mortalidade com a frequência das queimadas, sendo que na área com três queimadas trienais a taxa foi maior $\left(4,4 \%\right.$ ano $\left.^{-1}\right)$ do que na área com duas queimadas quinquenais $\left(2,1 \% \mathrm{ano}^{-1}\right)$. Os resultados destes estudos em comparação com os encontrados na Reserva da Embrapa Cerrados sugerem que as diferenças nas taxas de mortalidade podem estar relacionadas tanto ao regime de queima e quanto ao comportamento do fogo (SILVA et al., 1996a; MEDEIROS; MIRANDA, 2005; MIRANDA et al., 2010).

Na Área 1, as queimadas de 1988 e 1990, possivelmente, levariam à taxas de mortalidade, maiores do que 3,2\% ano ${ }^{-1}$. Em 1990, 2 anos após o primeiro levantamento, e antes da segunda queimada, o número de indivíduos vivos era 383 , houve redução de $42 \%$ em relação a 1988, quando havia 656 indivíduos. No entanto, as taxas de dinâmica foram calculadas para o período de 1991-1994, e não incluíram o período de 1988-1990, pois nesta época os indivíduos mortos não foram registrados. Vários estudos evidenciaram redução no número de indivíduos relacionados às queimadas (SILVA et al., 1996b; MEDEIROS; MIRANDA, 2005; RIBEIRO et al., 2012). Em Campo sujo, no Distrito Federal, submetido a três queimadas prescritas anuais, por exemplo, Medeiros e Miranda (2005) também observaram elevada redução no número de indivíduos vivos, cerca de $37 \%$. Em outro estudo, também em Campo sujo no Distrito Federal, com a vegetação protegida contra o fogo por 18 anos, Silva et al. (1996b) encontraram, após queimada prescrita, mortalidade variando com a época do ano, sendo de $2,1 \%$ após queimada em junho (precoce) e de $7 \%$ em setembro (tardia).

As queimadas afetaram, principalmente, os indivíduos de menor porte, com maior número de indivíduos mortos com até 2,4m de altura (64\%) e diâmetro até 5,5cm (76\%). Estes resultados são similares aos de Medeiros e Miranda (2005) que também encontraram maior mortalidade dos indivíduos arbóreo-arbustivos nas menores classes de altura (1 e 2 m) e de diâmetro (2 e 3 cm), em um Campo sujo, na Reserva Ecológica do IBGE (DF), após queimadas anuais. Estes resultados vêm de encontro à situação de que, geralmente, os indivíduos de menor porte são mais suscetíveis aos efeitos do fogo (MIRANDA et al., 2002). Além disso, cabe salientar, que, nestas plantas, quando a casca está menos espessa 
não oferece proteção contra as altas temperaturas durante as queimadas (GUEDES, 1993; MIRANDA; SATO, 2005).

As queimadas frequentes em intervalos curtos de tempo, de forma geral, podem impedir a regeneração da vegetação (SILVA et al., 1996b; MIRANDA; SATO, 2005), reduzindo assim, as taxas de recrutamento. $\mathrm{Na}$ Área 1, a primeira queimada levou à uma redução na densidade, em 1990, mas para o período de 1991-1994, a maior taxa de recrutamento comparada à de mortalidade refletiu no aumento da densidade de indivíduos vivos (Tabelas 3.1 e 3.2). No período de 1992-1993, porém, a mortalidade foi maior que o recrutamento, levando à redução da densidade, possivelmente, devido aos danos à vegetação em decorrência das queimadas anteriores e da terceira queimada de 1992. De 1993-1994 a mortalidade ainda foi maior que o recrutamento, porém a densidade em 1994 estava mais semelhante à de 1993.

As queimadas frequentes, bienais, podem ter dificultado o estabelecimento de rebrotas e a regeneração de algumas espécies na área (SILVA et al., 1996a), aumentando, assim, a taxa de mortalidade e reduzindo a de recrutamento. Altas taxas de mortalidade e baixas de recrutamento também podem indicar baixa capacidade competitiva dos indivíduos jovens e pouca resistência às queimadas (SILVA; ARAÚJO, 2009). De acordo com Aquino (2004) as flutuações nas taxas indicam o estágio sucessional em que se encontra a comunidade e ocorrem em função dos distúrbios ocorridos na área.

As maiores taxas de recrutamento em relação à mortalidade, para o período de 1991-1994, podem estar relacionadas à habilidade de algumas espécies em produzirem sementes após o fogo, ou desenvolverem indivíduos provenientes de sementes que resistem às queimadas, além da capacidade de algumas plântulas sobreviverem às queimadas recentes, e da habilidade de reprodução vegetativa (HOFFMANN, 1998; MIRANDA; SATO, 2005; ANDRADE; MIRANDA, 2010). Cabe enfatizar ainda, que, em muitas espécies, as plântulas apresentam rápido desenvolvimento do sistema radicular e têm a habilidade de rebrotar após as queimadas, atingindo o tamanho crítico de escape ao fogo (BRAZ et al., 2000; MIRANDA; SATO, 2005). Assim, o intervalo bienal entre as queimadas parece ter sido suficiente para permitir o desenvolvimento de regenerantes de algumas espécies, conforme as estratégias apontadas.

A taxa de recrutamento de 6,4\% ao ano, obtido na Área 2, protegida, pode ser considerada elevada, sendo também superior à da Área 1 (4,9\%), sugerindo que o fogo pode ter prejudicado a regeneração de algumas espécies nesta área. $\mathrm{Na}$ Bahia, em área preservada, Roitman et al. (2008) encontram taxas de mortalidade de $1,93 \%$ ano $^{-1}$ e de 
recrutamento de $3,72 \%$ ano $^{-1}$, que consideraram típicas de áreas protegidas de Cerrado sentido restrito. Na Área 2, o balanço positivo em favor do recrutamento sugere que esta área esteja em equilíbrio dinâmico em relação à recomposição da comunidade (ROITMAN et al., 2008; MEWS et al., 2011a). No entanto, nesta área as taxas de mortalidade foram sempre inferiores às de recrutamento refletindo no aumento crescente da densidade dos indivíduos ao longo do tempo.

$\mathrm{Na}$ Área 1, a maior taxa de mortalidade, e desbalanceamento positivo no recrutamento, resultou em tempos de meia vida (22 anos) e de substituição (18 anos) menores do que aqueles obtidos na Área 2 (50 e 30 anos, respectivamente), sugerindo que a Área 1 seja mais dinâmica que a Área 2. A Área 1 foi mais estável que a Área 2, pois apresentou valores de estabilidade ( 8 anos) menores do que a área 2 (39 anos), número de indivíduos mais similares e valores mais próximos de mortalidade e de recrutamento. Comparando com outros estudos, os resultados de Aquino et al. (2007a) foram mais próximos aos desta área com relação ao tempo de meia vida (25 e 14 anos), tempo de duplicação (22 e 12), estabilidade ( 3 e 2 anos) e tempo de substituição (23,5 e 13 anos), em duas áreas de Cerrado sentido restrito, com histórico de queimadas no Maranhão. Assim, a maior frequência do fogo e a taxa de recrutamento superior à de mortalidade, na Área 1, confirmam o processo dinâmico de estabelecimento da vegetação, padrão normalmente relacionado a locais que sofreram distúrbios (CARVALHO; FELFILI, 2011), e sugerem a alta resiliência ao distúrbio fogo da comunidade estudada.

$\mathrm{Na}$ Área 2, protegida contra o fogo até julho de 1994, por outro lado, houve redução da mortalidade e aumento do estabelecimento de novos indivíduos, refletindo, assim, em maior taxa de recrutamento e maior instabilidade nesta área. Com o desbalanceamento entre a taxa de mortalidade e de recrutamento o tempo de meia vida (50 anos) superou o de duplicação (11 anos) da comunidade, que também apresentou elevada estabilidade (39 anos) e substituição (30 anos). Os resultados de dinâmica observados nesta área, possivelmente, estão relacionados à ausência do fogo, com a baixa mortalidade e elevado recrutamento, e a manutenção da riqueza e estrutura da comunidade (Capítulo 1) ao longo do tempo, sugerindo que a área esteja em equilíbrio dinâmico (Aquino et al., 2007a). Mews et al. (2011a) também sugeriram que uma área protegida contra o fogo, em Mato Grosso, mas com um registro de incêndio anterior ao estudo, estava em equilíbrio dinâmico. Estes autores encontraram valores de tempo de meia vida (58,15 anos), de substituição (34,6 anos) e de estabilidade (47 anos) próximos aos encontrados na Área 2. 
O incremento periódico anual em diâmetro na Área $1\left(0,11 \mathrm{~cm} \cdot \mathrm{ano}^{-1}\right)$ e na Área 2 $\left(0,14 \mathrm{~cm} . \mathrm{ano}^{-1}\right)$ foram semelhantes às taxas obtidas, também em Cerrado sentido restrito, por Roitman et al. (2008), em área protegida do fogo na Bahia $\left(0,096 \mathrm{~cm}^{-a n o}{ }^{-1}\right)$ e por Aquino et al. (2007a), em Cerrado com histórico de queimadas no Maranhão (0,13 cm.ano ${ }^{1}$ e $0,17 \mathrm{~cm} . \mathrm{ano}^{-1}$ ) e menores que o encontrado por Mews et al. (2011a) em área de Cerrado sentido restrito, com registro de fogo, em Mato Grosso $\left(0,31 \mathrm{~cm} . \mathrm{ano}^{-1}\right)$. As diferenças nos valores encontrados nestas comparações podem estar associadas aos prolongados períodos de seca, bem como à fertilidade dos solos e às condições de preservação de cada área (HENRIQUES; HAY, 2002; AQUINO, et al., 2007a; MEWS et al., 2011a).

\section{Biomassa aérea}

$\mathrm{Na}$ área de estudo a resposta da vegetação ao acúmulo de biomassa esteve ligada à frequência das queimadas. No período de 1990 a 1994, a biomassa aérea estimada na Área 1, com queimadas bienais, variou de 8,5 Mg.ha' ${ }^{-1}$ a 9,8 Mg.ha ${ }^{-1}$ e foi significativamente menor do que na Área 2, que variou de 9,4 Mg.ha-1 a 11,7 Mg.ha' ${ }^{-1}$. Os resultados mostraram variação na quantidade de biomassa, com valores muito próximos até 1993 e redução em 1994, na área com queimada, indicando que a maior frequência das queimadas pode ter influenciado estes resultados. Nas duas áreas, os dados foram tomados sempre no ano seguinte à queimada e não foram obtidas estimativas logo após as queimadas. Como as queimadas afetaram principalmente os indivíduos de menor porte (Capítulo 2), possivelmente, alguns indivíduos que sofreram danos na parte aérea, tiveram tempo para recuperar a biomassa um e dois anos após o fogo até 1993. Além disso, provavelmente, o crescimento radial de alguns indivíduos também foi suficiente para repor as perdas decorrentes da mortalidade (LIMA et al., 2009).

A redução na biomassa em 1994, pode ter sido em consequência dos danos na parte aérea, com as três queimadas bienais, terem tornado os indivíduos maiores mais vulneráveis, levando à mortalidade, com dano total, ou mortalidade aérea, com danos parciais. Dentro deste contexto, cabe ressaltar que Castro e Kaufmann (1998) também encontraram menor biomassa em áreas com queimadas, em um Cerrado sentido restrito, na Reserva Ecológica do IBGE (DF). Estes autores avaliaram a biomassa aérea com e sem fogo, incluindo árvores e arbustos maiores que dois metros, e o diâmetro à altura do peito. Antes do fogo, estimaram a biomassa aérea em 12,8 Mg.ha ${ }^{-1}$ e 16,1 Mg.ha-1, 
respectivamente para Cerrado aberto e Cerrado denso, e, após o fogo, estimaram a biomassa em 10,8 Mg.ha' ${ }^{-1}$ e 15,8 Mg.ha ${ }^{-1}$.

Comparando os resultados com outros trabalhos, observou-se variação nas estimativas da biomassa, no entanto, alguns estudos apresentaram valores mais próximos aos encontrados nas duas áreas no período de 1990 a 1994. Barbosa e Fearnside (2005), por exemplo, encontraram 9,5 Mg.ha- ${ }^{-1}$ de biomassa seca, incluindo os indivíduos com diâmetro maior ou igual a 2 cm, em Roraima. Já na Fazenda Água Limpa (DF), Vale et al. (2002) estimaram a biomassa seca de árvores em 12,39 Mg.ha ${ }^{-1}$, incluindo indivíduos com diâmetro a $30 \mathrm{~cm}$ do solo maior ou igual a $5 \mathrm{~cm}$, e Rezende et al. (2006) estimaram em 9,85 Mg.ha' ${ }^{-1}$. Na Estação Ecológica do Jardim Botânico de Brasília (DF), área sem proteção contra o fogo, Miranda et al. (2011) avaliaram a biomassa aérea em doze anos e mencionaram que incêndios de grandes proporções ocorridos entre os dois levantamentos podem ter influenciado os resultados, estimados em 11,20 Mg.ha-1 (em 1997) e 13,59 $M_{g} \cdot h^{-1}$ (em 2009). Em outra área de Cerrado, em Silvânia (GO), em 21 anos, estes autores observaram perda de biomassa, sendo estimada em 18,85 Mg.ha-1 (em 1989) e 16,63 Mg.ha $^{-1}$ (em 2010), e, em Correntina (BA) estimaram, também em 21 anos, valores de 11,84 Mg.ha ${ }^{-1}$ (em 1989) e 14,19 Mg.ha-1 (em 2010).

As variações entre as estimativas destes estudos em comparação com a área da Reserva da Embrapa Cerrados podem ser resultado das diferenças metodológicas, da heterogeneidade na estrutura da vegetação, bem como da frequência das queimadas e de outros distúrbios nas áreas mencionadas (CASTRO; KAUFMANN, 1998; BUSTAMANTE; OLIVEIRA, 2008; MIRANDA et. al., 2011; MIRANDA, 2012). As condições climáticas durante as queimadas, a topografia e a umidade do combustível também podem influenciar a quantidade de combustível consumido (CASTRO; KAUFMANN, 1998), e consequentemente a biomassa estimada nas áreas comparadas.

A proteção contra o fogo por 18 anos favoreceu o aumento da biomassa aérea estimada nas duas áreas de estudo, sendo significativamente maior na Área 1, e também maior do que os valores encontrados em outros locais. No entanto, em área de Cerrado sentido restrito, em Curvelo (MG), Ribeiro et al. (2011) estimaram valores de biomassa

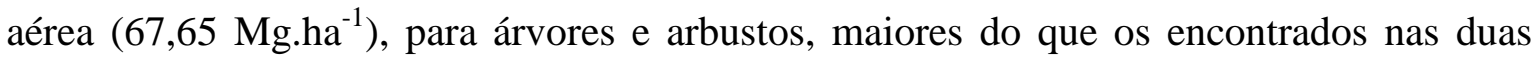
áreas (Área 1, Área 2) da Embrapa Cerrados. Já Lilienfien et al. (2001) calcularam 19,77

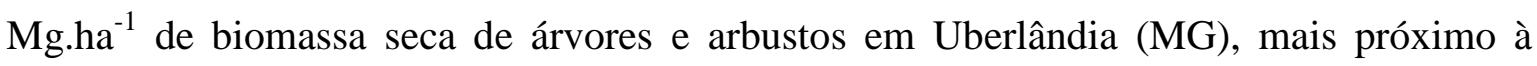
biomassa estimada da Área 2, em 2012. E Abdala et al. (1998), também no Distrito Federal, estimaram a biomassa aérea para árvores e arbustos, com circunferência a $30 \mathrm{~cm}$ 
do solo, maior que $6 \mathrm{~cm}$, encontrando 26,02 Mg.ha ${ }^{-1}$, mais próximo ao observado na Área 1, com 18 anos de proteção contra o fogo.

As estimativas de biomassa indicaram maiores valores nas áreas protegidas contra o fogo, no entanto, a variação nas comparações entre os estudos citados acima, bem como entre as duas áreas da Reserva da Embrapa Cerrados, evidencia a heterogeneidade florística frequentemente encontrada em Cerrado sentido restrito onde, mesmo em áreas próximas, as comunidades podem ser estruturalmente diferenciadas (FELFILI; SILVA JR., 1993; FELFILI; FELFILI, 2001; FELFILI et al., 2004; CARVALHO et al., 2008). Além disso, as diferenças nas metodologias e nas condições de conservação de cada área também podem ter influenciado a variação nas estimativas.

\section{Rebrotas}

Altas frequências de fogo tendem a limitar a reprodução sexuada (HOFFMANN; MOREIRA, 2002) e a aumentar a reprodução vegetativa, favorecendo espécies mais resistentes (HOFFMANN, 1998; ANDRADE; MIRANDA, 2010) no Cerrado. O maior número de espécies e de indivíduos com rebrotas basais (121 indivíduos), em comparação ao número de recrutas (67 indivíduos), na Área 1, com queimadas bienais, bem como o maior número de recrutas (167 indivíduos) e menor de indivíduos que rebrotaram (18 indivíduos) na Área 2, protegida contra a ação do fogo até julho de 1994, sugere o favorecimento de espécies com capacidade de reprodução assexuada na área ocorrência de queimadas.

Várias espécies, que têm habilidade de rebrotar, podem se desenvolver mais rapidamente após o fogo, em comparação às espécies que dependem da reprodução sexuada, que muitas vezes têm estas estruturas destruídas pelo fogo (HOFFMANN, 1999; MEDEIROS, 2002). Das 74 espécies registradas na Área 1, 36 (49\%) formaram rebrotas basais ou subterrâneas, sugerindo o favorecimento de espécies mais resistentes ao fogo, bem como a importância dos órgãos subterrâneos como mecanismo adaptativo ao fogo. Assim, os resultados confirmam a relevância da reprodução vegetativa, basal ou subterrânea, principalmente na Área 1, no período com queimadas. Em área de Campo sujo com alta frequência de queimadas, a maior proporção de indivíduos com rebrotas basais ou subterrâneas em comparação às rebrotas aéreas (MEDEIROS; MIRANDA, 2008) reforça a 
importância deste tipo de propagação, principalmente, em indivíduos que tiveram danos moderados.

Os danos causados pelo fogo, de forma geral, são maiores em plântulas e indivíduos jovens que ainda não têm casca espessa para garantir proteção contra altas temperaturas durante as queimadas (SATO et al., 2010). A espessura da casca é um atributo importante que confere proteção contra o fogo (MIRANDA et al., 2002; HOFFMANN et al., 2009; CLARKE et al., 2013), sendo determinante na sobrevivência e no tipo de danos causados pelas queimadas (PAUSAS, 2015; SOUCHIE, 2015).

O tipo de resposta ao fogo foi relacionado com a espessura da casca em estudos de Souchie (2015). De acordo com a autora os indivíduos com casca mais espessa, diâmetro e altura maiores apresentaram menos danos com a passagem do fogo, além de tenderem a apresentar rebrotas epígeas. Desta forma, a mortalidade aérea (topkill), observada nos indivíduos de menor porte na área com queimadas bienais (Área 1) foi, provavelmente, em razão destes ainda não possuírem casca espessa o suficiente para garantir que sobrevivessem às elevadas temperaturas das queimadas. A morte da parte aérea (topkill), com rebrota basal ou subterrânea, pode reduzir o porte das plantas (HOFFMANN, 1999; HOFFMANN; SOLBRIG, 2003; MIRANDA; SATO, 2005), no entanto, com a perda da parte aérea (topkill) de alguns indivíduos na área com queimadas bienais, as plantas menores podem ter recuperado o seu tamanho anterior (HOFFMANN; SOLBRIG, 2003), rebrotando após o distúrbio.

Por outro lado, com as queimadas sucessivas, o possível esgotamento das substâncias de reserva nos tecidos subterrâneos pode ter limitado o desenvolvimento de algumas rebrotas (MEDEIROS, 2002; RIBEIRO et al., 2012), justificando o menor número de rebrotas observado em 1994. Ribeiro et al. (2012) relacionaram o padrão de rebrotamento com o tamanho dos indivíduos, sendo proporcionalmente maior nas menores classes de tamanho. Estes autores mencionaram que os caules menores que sobreviveram, com a destruição da parte aérea, provavelmente utilizaram os recursos estocados em órgãos subterrâneos, mas ainda permaneceram nas menores classes, como também observado neste estudo.

A reprodução assexuada é característica de várias plantas do Cerrado e é mencionada como uma das estratégias de resistência ao fogo (MIRANDA; SATO, 2005; SARTORELLI et al., 2007), o que está de acordo com os resultados encontrados na Embrapa Cerrados, onde a propagação, por meio de rebrotas basais e subterrâneas, teve grande relevância na manutenção das espécies na área com queimadas bienais. Dentre as 
36 espécies que rebrotaram durante o período com queimadas bienais (1988 a 1994), três (Aegiphila verticillata, Erythroxylum campestre, Qualea multiflora) não foram registradas em 2012, após 18 anos de proteção. No entanto, 33 foram registradas no estrato arbóreoarbustivo em 2012, sugerindo resistência diante do fogo. Estes resultados confirmam elevadas resistência e resiliência da vegetação do Cerrado com relação ao distúrbio, também mencionadas por Medeiros e Fiedler (2011), Ribeiro et al. (2012) e Souchi (2015).

\section{Grupos funcionais}

O fogo pode agir como um filtro ambiental, estruturando as características funcionais, reunindo espécies com características funcionais semelhantes (SILVA; BATALHA, 2010; CIANCIARUSO et al., 2012), e eliminando espécies com pouca ou nenhuma característica de adaptação a este distúrbio (MEDEIROS; MIRANDA, 2005; SILVA et al., 2011; ZILLI et al., 2014), e, assim, as queimadas frequentes podem reduzir a diversidade funcional de uma comunidade (CIANCIARUSO et al., 2010; SILVA et al., 2011). Na avaliação da formação dos grupos funcionais presentes nas duas áreas com diferentes históricos de queimadas, em 1994 e em 2012, os resultados mostraram diferenças nos grupos funcionais formados nas duas áreas e épocas estudadas, e indicaram que a maior frequência do fogo, na Área 1, em 1994, reuniu espécies funcionalmente semelhantes. Por outro lado, o tempo de exclusão do fogo favoreceu algumas espécies, e a ocorrência de maior diversidade de atributos em 2012.

$\mathrm{Na}$ Área 1, em 1994, as espécies possuíam, principalmente, características relacionadas à reprodução e resistência diante do distúrbio. Formaram-se quatro grupos, onde o fogo selecionou espécies com características similares, tais como o hábito de crescimento (todas eram arbóreas), o tipo de casca áspera (somente uma lisa) e a polinização (zoófila). A característica determinante na formação dos diferentes grupos, na Área 1, em 1994, foi o tipo de dispersão (zoocórica e anemocórica). A capacidade de rebrotar também foi importante, pois somente três espécies não foram capazes de rebrotar. No grupo das espécies zoocóricas (A, B, C), havia espécies capazes de rebrotar e aquelas que não rebrotaram foram minoria. As espécies que não rebrotaram eram decíduas e as que rebrotaram eram decíduas ou sempre-verdes. O grupo A, mais rico em espécies e mais diverso em atributos, incluiu as espécies zoocóricas, com capacidade para rebrotar e casca áspera, indicando elevada contribuição para a manutenção da comunidade diante do distúrbio. 
De forma geral, as síndromes de polinização e dispersão estão ligadas à habilidade de recolonização diante de distúrbios (CIANCIARUSO et al., 2012; PÉREZHARGUINDEGUY et al., 2013), e no Cerrado, as espécies zoocóricas, geralmente, seguem um padrão de dispersão durante o período chuvoso, e, com os frutos se mantendo atrativos por períodos mais prolongados (BATALHA et al., 1997; LENZA; KLINK, 2006), provavelmente, as espécies dos três grupos (A, B, C) tiveram maiores chances de dispersão e estabelecimento no período entre as queimadas bienais. $\mathrm{O}$ grupo $\mathrm{D}$ foi o mais abundante, e incluiu o grupo das espécies anemocóricas, onde todas as espécies rebrotaram, e eram decíduas ou sempre-verdes.

A anemocoria pode ser consequência da sazonalidade climática do Cerrado e da deciduidade foliar, pois espécies decíduas, geralmente, perdem suas folhas durante o período seco, facilitando a dispersão dos diásporos pelo vento nesta época (BATALHA; MANTOVANI, 2000; LENZA; KLINK, 2006; REIS et al., 2012). Com as queimadas frequentes durante o período seco, o grupo de espécies anemocóricas, provavelmente, teve a reprodução sexuada reduzida, pela queima dos frutos e sementes, investindo na propagação vegetativa, já que todas as espécies foram capazes de rebrotar. A reprodução sexuada depende de vetores da polinização (OLIVEIRA; GIBBS, 2000; SILVA et al. 2012) e o predomínio de espécies polinizadas e dispersas, na maioria, por animais reforça a importância dos insetos e outros animais na área analisada, no entanto, a capacidade de rebrotar mostrou ser uma importante estratégia de resistência ao distúrbio entre as espécies estudadas.

O tipo de casca também foi importante atributo, que tem sido mencionado como essencial para a sobrevivência de algumas espécies do Cerrado diante das queimadas (VALE; ELIAS, 2014). Além da espessura da casca, a arquitetura externa da casca morta também é fator importante para proteger o câmbio (VALE et al., 2009), podendo influenciar o efeito isolante da casca, devido às irregularidades na sua superfície (MAZZONI-VIVEIROS; COSTA, 2003), e, consequentemente, diminuir a mortalidade das plantas pelo fogo (SILVA, 2013). Esta característica enfatiza a importância do tipo de casca áspera nesta área, onde somente uma espécie, Guapira graciliflora, apresentou casca lisa, mas também capacidade de rebrotar.

As principais adaptações entre as espécies lenhosas na Área 1 estavam relacionadas ao isolamento térmico dos tecidos internos com a suberização do tronco e ramos, reprodução clonal e habilidade para rebrotar de regiões subterrâneas (CIANCIARUSO et al., 2012). Os resultados encontrados evidenciaram a importância dessas características nas 
espécies analisadas, já que estas apresentavam casca áspera, indicando suberização, e habilidade para rebrotar. Além disso, na área com queimadas bienais no período de 1988 a 1992 (Área 1), todas as espécies eram arbóreas. A forma de vida pode estar associada ao vigor competitivo e à resposta aos distúrbios (CORNELISSEN et al., 2003; ZILLI et al., 2014). E, o fato de que algumas espécies arbustivas do Cerrado sentido restrito tendem a apresentar sistema radicular mais superficial, e as espécies arbóreas têm variação no sistema radicular, podendo ser capazes de retirar água tanto de regiões profundas quanto de superficiais (GOLDSTEIN, et al., 2008; ROSSATO, 2011), também pode justificar o favorecimento das espécies arbóreas na área com as queimadas frequentes.

Na Área 2, em 1994, a proteção da área contra o fogo proporcionou a formação de grupos diferenciados em comparação com a Área 1. Houve acréscimo de outros atributos, como forma de vida arbustiva, bem como a formação de um grupo com espécies anemocóricas que não rebrotaram, indicando a presença de outras estratégias que não estavam relacionadas com a resistência ao fogo e sugerindo maior diversidade de caracteres funcionais. Formaram-se quatro grupos, e uma espécie, Protium ovatum, ficou isolada. Todas as espécies tinham polinização zoófila. Os grupos também foram divididos principalmente pelo tipo de dispersão zoocórica e anemocórica, mas com uma espécie, Stryphnodendron adstringens, tendo dispersão barocórica, além da dispersão por animais. Nesta área formaram-se dois grupos com espécies zoocóricas e dois com espécies anemocóricas, sendo que na Área 1, também em 1994, formaram-se três grupos com espécies zoocóricas e um com anemocóricas, indicando a inclusão de outros traços funcionais na Área 2, protegida contra a ação do fogo. A maioria das espécies zoocóricas apresentou caule com casca áspera (duas lisas); e todas as anemocóricas possuíam casca áspera, indicando ser uma característica relevante. A casca tem importante função na proteção da planta não somente nas queimadas (VALE et al., 2009), mas também do ataque de patógenos, dos herbívoros, nas geadas e nas secas (CORNELISSEN et al., 2003).

O grupo das espécies zoocóricas $(\mathrm{A}, \mathrm{C})$ foi dividido entre as espécies capazes de rebrotar (decíduas e sempre-verdes) e aquelas que não rebrotaram (decíduas) com a inclusão do hábito arbustivo, que não ocorreu na Área 1, com queimadas bienais. As plantas arbustivas podem ser consideradas sensíveis ao fogo, pelo fato de algumas espécies do Cerrado sentido restrito possuírem sistema radicular mais superficial e não serem capazes de retirar água de regiões profundas como as arbóreas (GOLDSTEIN, et al., 2008; ROSSATO, 2011). O grupo das anemocóricas (B, D) também foi dividido entre espécies 
que rebrotaram (decíduas e sempre-verdes) e aquelas que não rebrotaram (sempre-verdes) formaram um grupo que também não ocorreu na Área 1.

As síndromes de polinização e dispersão são importantes no sucesso reprodutivo das plantas (ZILLI et al., 2014), e, o predomínio de espécies polinizadas por animais, a variação na dispersão, com espécies sendo zoocóricas e anemocóricas, além da formação de dois grupos com espécies sem capacidade de rebrotar, reforçam a importância da reprodução sexuada na área protegida contra o fogo até julho de 1994 (Área 2). De forma geral, no Cerrado, as espécies anemocóricas seguem um padrão de frutos sendo dispersos de forma mais eficiente na época seca (BATALHA et al., 1997; BATALHA; MANTOVANI, 2000), justificando assim, o maior número de grupos com espécies anemocóricas na Área 2, protegida contra o fogo, em comparação com a Área 1 que teve somente um grupo, além de reforçar a importância dessas espécies na manutenção da comunidade.

Em 2012, nas duas áreas com diferentes históricos de queimadas formaram-se grupos com características distintas. Na Área 1, com quatro ocorrências de fogo, e 18 anos sem queimar, houve modificação dos grupos, desde 1994. Nas análises de 1994 havia somente espécies arbóreas, com casca áspera na maioria (com uma lisa) e aquelas que não rebrotaram eram decíduas e zoocóricas. Os resultados de 2012 indicaram a inclusão de 15 espécies nas análises em relação a 1994 e de outros atributos que não caracterizam resistência ao fogo, como a forma de vida arbustiva, e o maior número de espécies que não rebrotaram e com casca lisa, além da polinização anemófila. O grupo das espécies que rebrotaram foi dividido entre espécies decíduas (A) e sempre-verdes (B), com mais de um tipo de dispersão. E o grupo das espécies que não rebrotaram foi dividido em decíduas com anemocoria, zoocoria e autocoria (C), em decíduas e sempre-verdes com zoocoria (D), e em decíduas (arbustos de casca lisa) com zoocoria e autocoria (E). A maioria das espécies neste ano teve polinização por animais, com uma, Maprounea guianensis, sendo polinizada pelo vento (anemofilia). A característica mais marcante para a formação dos grupos foi a capacidade de rebrotar, sendo que em três, dos cinco grupos, as espécies não rebrotaram.

A capacidade de rebrotar é considerada uma característica importante na história de vida de algumas plantas do Cerrado (RIBEIRO et al., 2012), e desta forma, os resultados alcançados na Embrapa Cerrados corroboram com o fato de que esta habilidade promove a persistência de algumas espécies após distúrbios (CIANCIARUSO et al., 2012; SILVA, 2013), como queimadas e corte de árvores (CORNELISSEN et al., 2003). A capacidade de rebrotar após queimadas foi observada em 64\% das espécies estudadas em 2012, 
sugerindo a importância deste atributo e também, que a exclusão do fogo por 18 anos favoreceu a entrada de espécies que não rebrotam, em relação ao período 1988-1994, quando todas as espécies rebrotaram. Assim, a proteção contra o fogo promoveu a entrada de espécies sensíveis (HOFFMAN, 1998), com a inclusão de mais espécies com casca lisa, que não rebrotam, e o maior número de espécies de hábito arbustivo, indicando maior diversidade de traços funcionais (CIANCIARUSO, 2009).

Na Área 2, após 18 anos sem queimar, em 2012, e com histórico distinto de fogo, em relação à Área 1, também teve a formação de cinco grupos, onde a característica mais marcante na separação dos grupos foi o tipo de casca (lisa e áspera), evidenciando a importância de outros atributos, como a casca lisa, nesta área. A casca tem importante função na proteção do câmbio, xilema e floema do ataque de patógenos, dos herbívoros, bem como das geadas, das secas (CORNELISSEN et al., 2003) e das altas temperaturas durante as queimadas (GUEDES, 1993). Dentro do grupo das espécies com casca áspera a maioria das espécies decíduas rebrotou (A), mas quanto às sempre-verdes algumas foram capazes de rebrotar (B) e outras não rebrotaram (C). Quanto ao grupo das espécies com casca lisa, as espécies que não rebrotaram eram decíduas ou sempre-verdes (grupo D), e aquelas capazes de rebrotar eram decíduas (grupo E).

A habilidade para rebrotar está relacionada ao vigor competitivo e à persistência das espécies após distúrbios (CIANCIARUSO et al., 2012; SILVA, 2013), como queimadas e corte de árvores (CORNELISSEN et al., 2003). A capacidade de rebrotar a partir da base do caule e de órgãos subterrâneos foi uma característica essencial para a manutenção das espécies na comunidade estudada, sendo observada em $76 \%$ das espécies, entre decíduas e sempre-verdes.

Quanto à deciduidade, as espécies decíduas foram menos abundantes, mas maioria (65\%); já as espécies perenifólias tiveram maior número de indivíduos e foram representadas por 35\% do total das espécies nesta área em 2012. Na Embrapa Cerrados, possivelmente, a fenologia foliar esteve relacionada à luminosidade, onde a queda das folhas na estação seca proporcionou a abertura do dossel, e teve consequências na regeneração de algumas espécies (VALE et al., 2013). Geralmente, as espécies decíduas apresentam períodos muito curtos de exposição foliar, fora do pico principal das folhas de espécies mais competitivas (PRADO JR. et al., 2012). Já as perenifólias, geralmente, mantêm as folhas durante todo ano, mas podem desfavorecer algumas espécies exigentes de luz (VALE et al., 2013), também tendo consequências na regeneração de algumas espécies. E desta forma, a coocorrência de espécies decíduas e sempre-verdes, nesta área, 
também pode ser um indicativo de diferentes estratégias quanto ao uso de água e resistência à seca (SOUZA et al., 2015).

Diante do exposto, além dos diferentes históricos de fogo no fragmento estudado na Embrapa Cerrados (DF), a pressão antrópica dos últimos anos, devido aos assentamentos, condomínios e fazendas do entorno da área, e o pisoteio eventual do gado bovino também podem ter influenciado na formação dos distintos grupos funcionais nas duas áreas, após o período de 18 anos de conservação estabelecido.

\subsection{CONCLUSÕES}

A incidência de queimadas bienais, em um período de seis anos, aumentou a mortalidade e reduziu o recrutamento de indivíduos, implicando em menores tempos de meia vida e de substituição.

A incidência de queimadas bienais, em um período de seis anos, diminuiu a biomassa aérea, e favoreceu a reprodução assexuada, com estímulo da formação de rebrotas basais ou subterrâneas.

A maior frequência do fogo na Área 1, em 1994, reuniu espécies funcionalmente semelhantes, com menor diversidade de atributos, nos grupos formados neste ano.

A proteção contra a ação do fogo por 18 anos favoreceu o aumento da biomassa aérea nas duas áreas.

A proteção, das duas áreas, contra a ação do fogo por 18 anos favoreceu a entrada de algumas espécies e a maior diversidade de atributos nos grupos funcionais formados em 2012. 


\section{4 - MUdANÇAS NO ESTRATO HERBÁCEO EM FRAGMENTO DE CERRADO SENTIDO RESTRITO SOB QUEIMADAS BIENAIS, NO DISTRITO FEDERAL}

\section{RESUMO}

O monitoramento da vegetação do estrato herbáceo foi realizado em um fragmento de Cerrado sentido restrito em Planaltina (DF), em oito ocasiões de 1988 a 2012. Em duas áreas de 1,25 ha (Área 1, Área 2), com diferentes históricos de fogo, foram demarcadas duas transecções de 100 metros de comprimento. Utilizou-se o método de interceptação na linha onde cada transecção foi subdividida em 100 unidades amostrais de 1 metro, totalizando 200 unidades amostrais em cada área. Na Área 1 houve a aplicação de queimada bienal em 1988, 1990 e 1992, e a Área 2 foi protegida contra a ação do fogo até julho de 1994. Em agosto de 1994 um fogo acidental atingiu as duas áreas. As áreas foram protegidas contra o fogo de 1995 a 2012. Em cada unidade amostral foram registradas as espécies de diferentes hábitos (árvore, arbusto, subarbusto, erva, trepadeira) até a altura de um metro. Na Área 1 foram observadas de 92 a 134 espécies no período de 1988 a 1994, e 115 em 2012. Na Área 2 foram registradas de 97 a 129 espécies, de 1988 a 1994, e 106 em 2012. As queimadas bienais não modificaram a riqueza de espécies e a diversidade, mas alteraram a estrutura da comunidade. As duas áreas, após 18 anos de exclusão do fogo, não mostraram alterações na riqueza, mas apresentaram mudanças na diversidade e na estrutura da comunidade. A exclusão do fogo por 18 anos promoveu a similaridade florística entre as duas áreas. Com a aplicação do teste de Kolmogorov-Smirnov foram detectadas diferenças significativas na distribuição das frequências relativas das espécies entre as duas áreas em 1989, em 1993 e em 2012. Os resultados anuais não mostraram diferenças na riqueza de espécies do estrato herbáceo durante o período de 1988 a 1994, e em 2012, podendo ser um indicativo da recuperação após as queimadas e da resiliência da comunidade do estrato herbáceo diante do distúrbio.

Palavras-chave: fogo, florística, riqueza, diversidade, estrutura, camada herbácea 


\subsection{INTRODUÇÃO}

O Bioma Cerrado apresenta grande riqueza de espécies (MENDONÇA et al., 2008), com maior proporção de espécies herbáceas do que arbóreas, refletindo a maior área ocupada por formações savânicas e campestres em relação às florestais (BATALHA; MANTOVANI, 2001; MENDONÇA et al., 2001; MENDONÇA et al., 2008). No entanto,

o Cerrado vem passando por mudanças de origem antrópica associadas ao fogo, desmatamento e invasão de espécies exóticas (HENRIQUES; HAY, 2002). A ocorrência de queimadas frequentes, geralmente, reduz a densidade das plantas lenhosas e favorece a colonização do estrato herbáceo do Cerrado (MOREIRA, 2000), podendo alterar a composição florística (SILVA; NOGUEIRA, 1999; LOIOLA et al., 2010; SILVA et al., 2011) e a estrutura das comunidades (ROSA, 1990; AMARAL, 2008; MIRANDA, 2002; SALAZAR; GOLDSTEIN, 2014), e com isso a frequência de espécies raras da camada rasteira (MUNHOZ; AMARAL, 2010). Por outro lado, períodos longos de exclusão do fogo, podem estimular o crescimento e reprodução da vegetação arbustiva e arbórea e consequentemente inibir o crescimento do estrato herbáceo (GARDNER, 2006) e ocasionar a redução na riqueza de espécies no estrato rasteiro (MUNHOZ; FELFILI, 2006; MEDEIROS; FIEDLER, 2011).

O Cerrado está propenso às queimadas, especialmente, na época seca, quando a camada herbácea seca (ONIGEMO et al., 2003; SALAZAR; GOLDSTEIN, 2014) e as gramíneas representam a maior parte da biomassa suscetível à combustão (MIRANDA et al., 2004; MEWS et al., 2013). O aumento da densidade de gramíneas e de biomassa seca, geralmente, ocasiona incêndios de maior intensidade, com maior mortalidade das espécies lenhosas e redução da cobertura do solo (CARDOSO et al., 2000b; MEWS et al., 2013). Com isso, o fogo, que é de superfície com chamas de 1,2 a 2,9 m de altura, atinge, principalmente, as folhas e ramos mais baixos do estrato arbóreo-arbustivo e o combustível fino do estrato rasteiro (MIRANDA et al., 2010).

A recuperação da vegetação herbácea pode variar com a época e frequência do fogo, fisionomia e composição das espécies (ROSA, 1990; SILVA; NOGUEIRA, 1999; ONIGEMO et al., 2003; MIRANDA et al., 2009). A vegetação do estrato herbáceo, que é queimada durante os incêndios, (MIRANDA et al., 2004; MEWS et al., 2013), é altamente resiliente ao fogo (MIRANDA et al., 2009). Algumas espécies são anuais, crescendo na estação chuvosa (MIRANDA et al., 2002) e várias outras possuem características de adaptação às queimadas que lhes permitem sobreviver ou regenerar rapidamente após o 
distúrbio, resultando em baixa mortalidade e floração massiva e vigorosa brotação alguns dias ou semanas após o fogo (COUTINHO, 1990; MIRANDA et al., 2010). Uma característica importante, de algumas gramíneas e ciperáceas, é a presença de gemas que ficam protegidas pela estrutura de suas folhas, formando uma base densamente imbricada (COUTINHO, 1982, 1990). Outra característica da vegetação é a existência de órgãos subterrâneos, como xilopódios, bulbos e rizomas, em várias espécies do Cerrado, que são capazes de formar ramos aéreos e reprodutivos, após o fogo, devido às gemas que ficam protegidas abaixo do nível do solo (COUTINHO, 1982, 1990; APPEZZATO-DAGLÓRIA et al., 2008). O acúmulo de biomassa subterrânea também é uma estratégia vantajosa para muitas espécies herbáceas e subarbustivas do Cerrado, que investem grande parte de sua energia nas porções subterrâneas e ficam protegidas da ação das queimadas e das secas prolongadas (COUTINHO, 1990; DELITTI et al., 2001; FIDELIS; PIVELLO, 2011). A retirada da biomassa aérea pelo fogo estimula a produtividade da camada herbácea que cresce vigorosamente em poucos dias devido à maior incidência de luz e estímulo de rebrotas (HOFFMANN, 1996; CARDOSO et al., 2000b). Assim, várias espécies herbáceas florescem após a passagem do fogo (MUNHOZ; FELFILI, 2005; MUNHOZ; AMARAL, 2010), que atua como agente sincronizador da floração, com rebrota e restauração da parte aérea sendo seguidos pela produção de flores (SILVA; SANTOS, 2008).

A camada herbácea do Cerrado apresenta grande riqueza de espécies (MISTRY, 1998; FILGUEIRAS, 2002; MENDONÇA et al., 2008), mas os efeitos do fogo na florística e dinâmica ainda são pouco pesquisados. Estudos e monitoramento do componente herbáceo na vegetação do Cerrado sentido restrito ainda são necessários e fornecem subsídios para nortear as decisões em programas de manejo, implantação de práticas de conservação diante do distúrbio fogo, bem como para a utilização racional dos recursos vegetais. Assim, este capítulo teve como objetivos analisar e comparar a composição florística, riqueza e diversidade, bem como a estrutura da vegetação do estrato herbáceo de um fragmento de Cerrado sentido restrito, em uma área com ocorrência de queimadas bienais e em uma área protegida contra o fogo, no período de 1988 a 1994, e após 18 anos sem ocorrência deste distúrbio, em 2012. Com isso, procurou-se responder às seguintes perguntas: 1) A incidência de queimadas bienais, em um período de seis anos, favorece o aumento da riqueza e da diversidade, e altera a estrutura da comunidade do estrato herbáceo? 2) A proteção de duas áreas, com diferentes históricos de fogo, por 18 anos, diminui a riqueza e a diversidade da vegetação do estrato herbáceo? 3) A proteção 
contra a ação do fogo, por 18 anos, favorece a similaridade florística da camada herbácea entre áreas com diferentes históricos de fogo?

\subsection{MATERIAL E MÉTODOS}

\subsection{1 Área de estudo}

O trabalho foi desenvolvido em um fragmento de Cerrado sentido restrito na Reserva Cerrado (Figura 4.1) pertencente ao grupo de Reservas Ecológicas da Embrapa Cerrados, a Nordeste do Distrito Federal, na região administrativa de Planaltina (DF), nas coordenadas $15^{\circ} 38^{\prime} \mathrm{S}$ e $47^{\circ} 43^{\prime} \mathrm{W}$, datum horizontal Córrego Alegre, MG (PARRON et al., 1998). A área da reserva faz parte da Chapada da Contagem, que é a unidade geomorfológica mais elevada do Distrito Federal (PARRON et al., 1998). O solo é do tipo Latossolo Vermelho (SANTOS et al., 2013), textura muito argilosa, relevo plano a suave ondulado, fase cerrado (Typic haplustox), desenvolvido a partir da decomposição da cobertura detrítico-laterítica de caráter argiloso do Terciário (SPERA et al., 2000). O clima é caracterizado como Aw na classificação de Köppen, com uma estação seca de 5 meses, precipitação média anual de $1.577 \mathrm{~mm}$, temperatura média anual de $20,4{ }^{\circ} \mathrm{C}$, temperatura máxima média de $26,6^{\circ} \mathrm{C}$, e mínima média de $15,8^{\circ} \mathrm{C}$, com altitude de $1.100 \mathrm{~m}$ (SPERA et al., 2000). Na Tabela 4.1 são apresentados os dados de temperatura, umidade relativa e precipitação pluviométrica, de acordo com a estação climatológica da Embrapa Cerrados para o período de estudo de 1988 a 1994 e 2012.

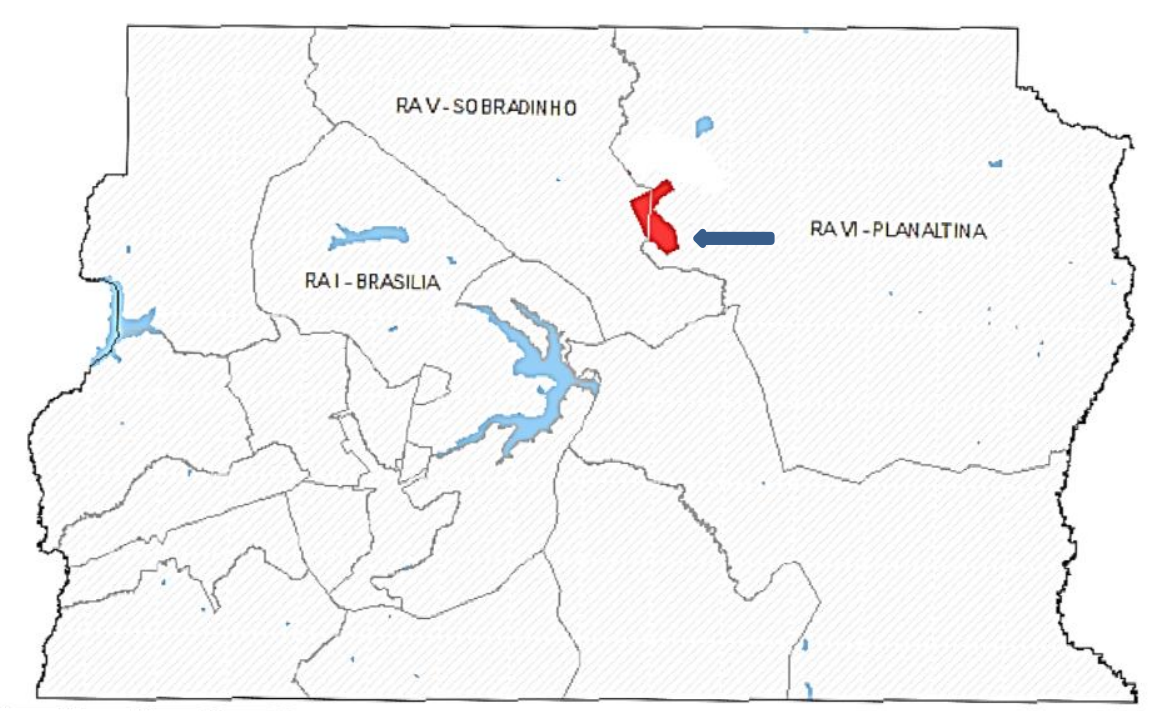

Figura 4.1 - Mapa do Distrito Federal destacando a área da Reserva Cerrado da Embrapa Cerrados, em Planaltina (DF), em vermelho. (Fonte: modificado de Aquino et al., 2009). 
Tabela 4.1 - Dados climatológicos de Temperatura Máxima Absoluta (TM), Mínima Absoluta (TN), Umidade Relativa do Ar (UR) e Precipitação pluviométrica total anual (PP) na Reserva Cerrado da Embrapa Cerrados, em Planaltina (DF), de 1988 a 1994 e em 2012.

\begin{tabular}{lcccccccc} 
Parâmetro & \multicolumn{7}{c}{ Ano } \\
\cline { 2 - 9 } & 1988 & 1989 & 1990 & 1991 & 1992 & 1993 & 1994 & 2012 \\
\hline TM $\left({ }^{\circ} \mathrm{C}\right)$ & 26,6 & 26,4 & 26,9 & 26,2 & 25,7 & 27,2 & 27,1 & 27,3 \\
TN $\left({ }^{\circ} \mathrm{C}\right)$ & 16,1 & 16,2 & 16,2 & 15,8 & 15,7 & 16,0 & 16,4 & 16,1 \\
$\mathrm{UR}\left({ }^{\%}\right)$ & 69,1 & 71,3 & 68,5 & 69,1 & 71,5 & 67,3 & 66,3 & 47,7 \\
PP $(\mathrm{mm})$ & 1818,6 & 1788,6 & 1348,1 & 1843,8 & 2220 & 1175 & 1568,3 & 1288,4 \\
\hline
\end{tabular}

Fonte: Estação climatológica da Embrapa Cerrados, Planaltina, DF.

\subsubsection{Histórico da área}

No ano de 1987, no mês de maio, um grupo de pesquisadores da Embrapa Cerrados, da Universidade de Los Andes - ULA (Mérida-Venezuela) e da Harvard University (EUA) iniciou uma série discussões sobre o projeto, o local e a metodologia a serem estabelecidos, e ainda neste ano o projeto foi oficializado na Embrapa Cerrados e na Embrapa Sede com o nome "Ecologia das Comunidades Vegetais de Cerrado Frente a Perturbações e Estresses" - 026870022, para ser iniciado em 1988, sob a coordenação do Dr. José Carlos Sousa Silva. As atividades de campo começaram em maio de 1988, quando houve implantação do projeto com a demarcação da área dos experimentos. As tomadas de dados foram iniciadas em junho e julho de 1988, com a participação dos pesquisadores Dr. José Carlos Sousa Silva, Dra. Maria Lúcia Meirelles e Dr. Carlos Augusto Klink. Em 2012, o levantamento dos dados ficou sob coordenação de Mary Naves da Silva Rios e José Carlos Sousa Silva.

O local do estudo tem um histórico de queimadas, onde, de acordo com informações de funcionários da Embrapa Cerrados, não houve registros de queimadas de 1979 a 1988, havendo proteção contra o fogo. Em agosto de 1994, no entanto, houve fogo acidental em toda área dos experimentos, porém, de 1995 até 2012 o local foi protegido contra o fogo, não havendo ocorrência de queimadas.

O entorno da área da Reserva Cerrado da Embrapa Cerrados era formado, principalmente, por chácaras até 1994, porém, em anos mais recentes, foi observado aumento do desmatamento com a criação de condomínios particulares e residenciais, 
assentamentos rurais e novas estradas. A área da fazenda experimental, além da reserva, inclui outros projetos de pesquisa com pastagem, gado bovino, culturas perenes, dentre outros. Com isso, esporadicamente, foi observada a presença de gado no local dos experimentos.

\subsubsection{Amostragem e coleta dos dados}

O levantamento da flora herbácea seguiu o método de interceptação na linha, transecto de linha ou interseção na linha (CANFIELD, 1941), que é indicado para estudos com vegetação herbáceo-graminosa (MEIRELLES et al., 2002; MUNHOZ; ARAÚJO, 2011) (Figura 4.2).

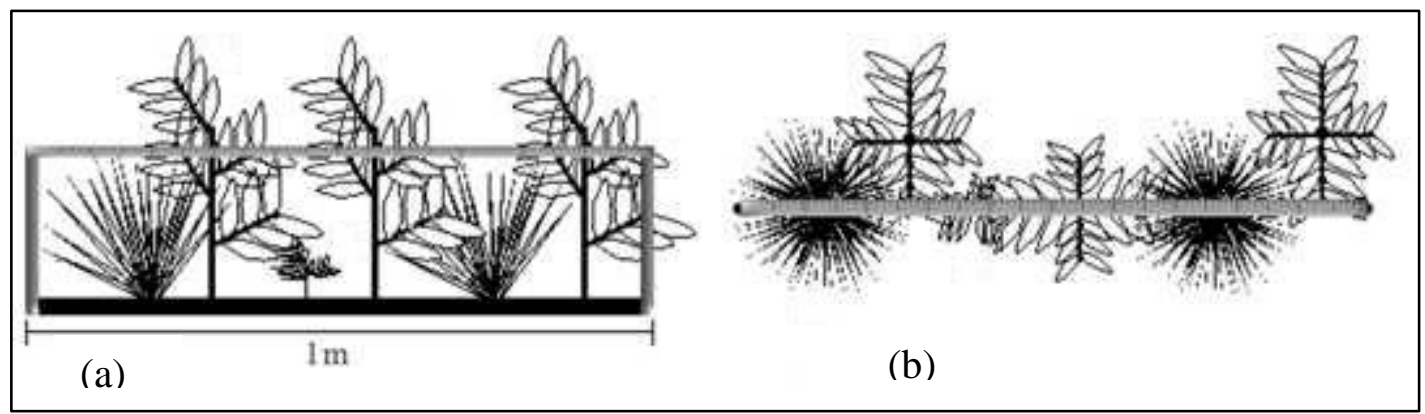

Figura 4.2 - Representação esquemática do método de interseção na linha, demonstrando como a unidade amostral é demarcada (a), e vista superior das espécies (Fonte: modificado de Munhoz e Araújo, 2011).

O trabalho foi conduzido em uma área 2,5 ha $\left(15^{\circ} 39.439^{\prime}\right.$ 'S, $47^{\circ} 44.411^{\prime \prime} \mathrm{W}$;

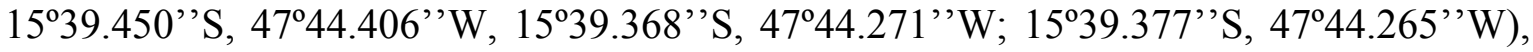
que foi dividida em duas áreas de cerca de 1,25 ha, com diferentes históricos de fogo, designadas neste estudo de Área 1 e Área 2. Foram demarcadas, em cada área, duas transecções com 100 metros de comprimento, separadas entre si por 20 m, sendo A e B, na Área 1, e C e D, na Área 2 (Figura 4.3). 


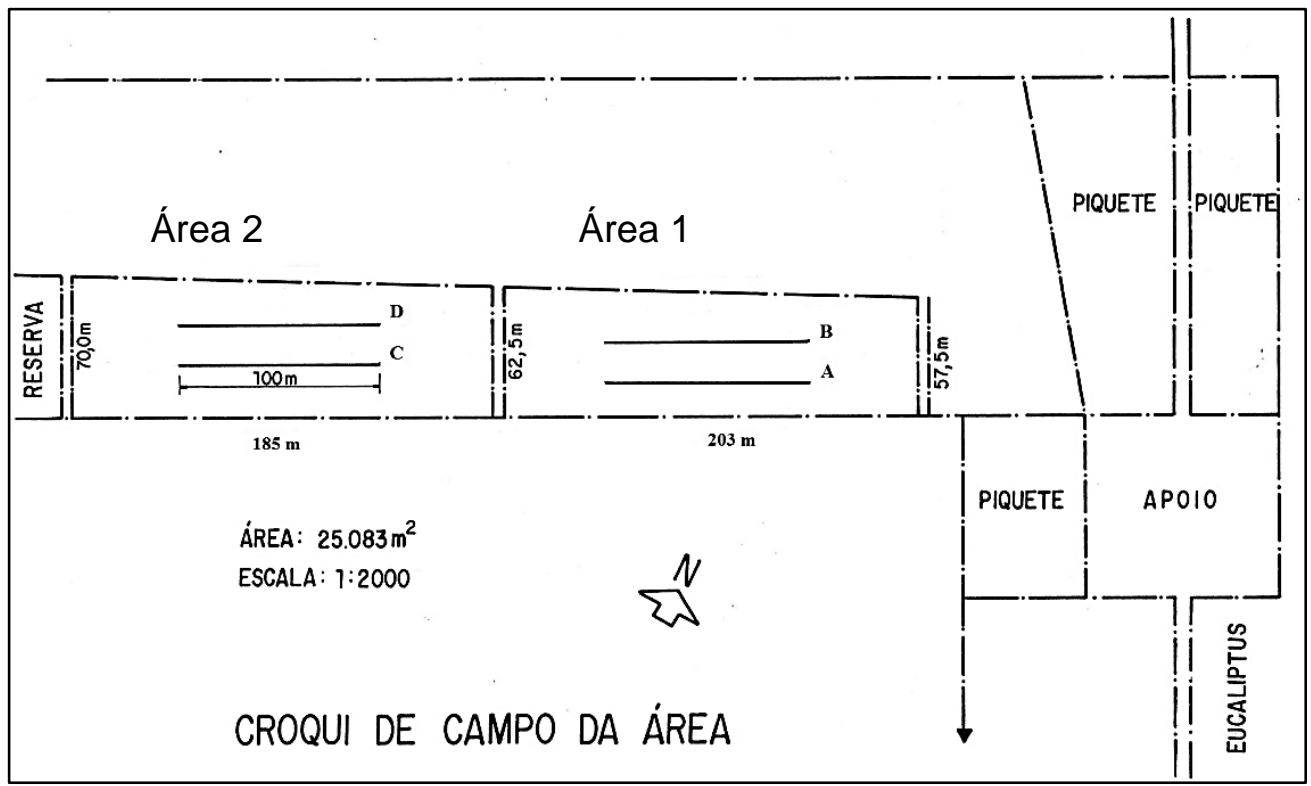

Figura 4.3 - Esquema do posicionamento das transecções em duas áreas de Cerrado sentido restrito na Reserva Cerrado da Embrapa Cerrados, em Planaltina (DF), sendo: Área $1=$ transecções A e B, com aplicação de queimadas bienais em 1988, 1990 e 1992, e proteção do fogo de 1995 a 2012; Área 2 = transecções C e D, com proteção contra o fogo de 1988 a julho de 1994, e de 1995 a 2012. (Coordenadas: 15³9.439' 'S, 47044.411''W;

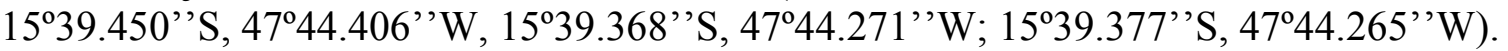

Na Área 1 (transecções A e B) houve a aplicação de queimadas bienais, que foram adotadas por serem mais comuns na região do Cerrado (COUTINHO, 1982, 1990; SATO, 2003). As queimadas controladas foram aplicadas em 1988, 1990 e 1992, sempre no mês de agosto, por ser a época de ocorrência mais frequente de queimadas na região de Brasília (COUTINHO et al., 1982; SATO, 1996) (Figura 4.4). Em 1994 não houve a aplicação da queimada controlada, pois houve a ocorrência de fogo acidental, também no mês de agosto, que atingiu as duas áreas. O fogo controlado foi colocado sempre pela manhã, por uma equipe previamente preparada de funcionários da Embrapa Cerrados. Antes de cada queimada foram construídos aceiros em volta da Área 1. A Área 2 (transecções C e D), foi protegida contra a ação do fogo até julho de 1994, pois em agosto de 1994 o fogo acidental também atingiu esta área. As duas áreas foram protegidas contra a ação do fogo de 1995 a 2012. 


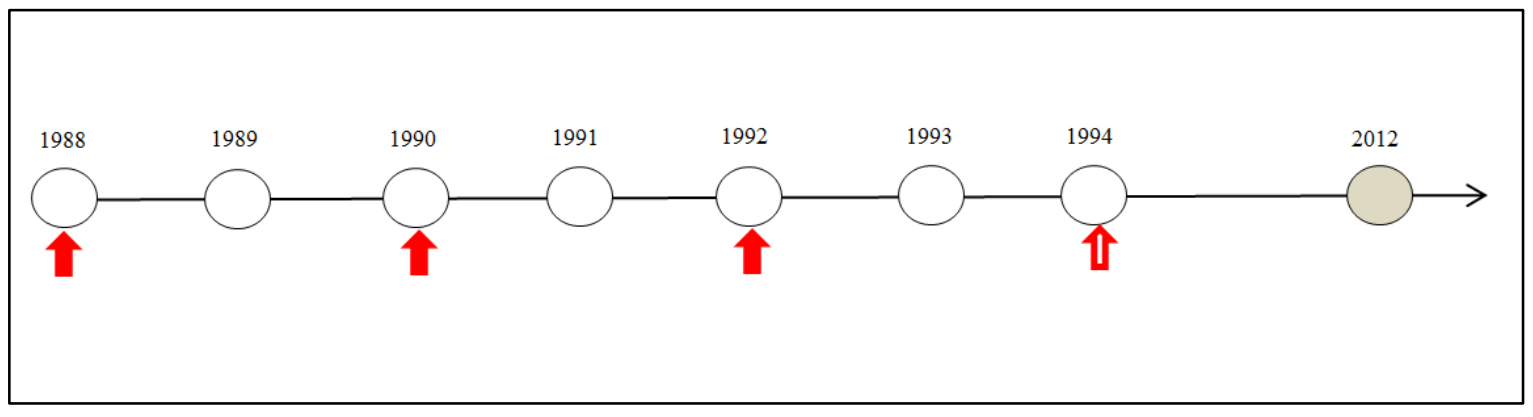

Figura 4.4 - Linha representativa indicando oito ocasiões do monitoramento (1988, 1989, 1990, 1991, 1992, 1993, 1994, 2012), o levantamento dos dados, a aplicação de queimadas controladas, e a ocorrência de fogo acidental, em duas áreas de Cerrado sentido restrito, na Reserva Cerrado da Embrapa Cerrados, em Planaltina (DF), sendo: $\uparrow$ = aplicação de queimada controlada no mês de agosto, na Área 1 ; $\uparrow=$ fogo acidental no mês agosto, nas duas áreas (Área 1, Área 2); $\bigcirc=$ levantamento dos dados em junho-julho, nas duas áreas (Área 1, Área 2); $\bigcirc$ = levantamento dos dados em agosto, nas duas áreas (Área 1, Área 2).

O monitoramento da vegetação da camada herbácea teve início em 1988 e foi realizado sempre antes do fogo, em oito ocasiões (1988, 1989, 1990, 1991, 1992, 1993 , 1994, 2012). De 1988 a 1994 foram feitos levantamentos nos meses de junho-julho, e em 2012, em agosto, ainda no período seco (Figura 4.4). Assim, as duas áreas tiveram diferentes históricos de fogo, já que a área 2 também passou por uma queimada em agosto de 1994 e, de 1995 até 2012 ficaram protegidas.

A demarcação das unidades amostrais foi realizada em maio de 1988. Cada uma das transecções foi subdividida em 100 Unidades Amostrais (UA's) de um metro, totalizando 200 unidades amostrais na Área 1, com queimadas bienais, e 200 na Área 2. Em todo período (1988 a 1994 e 2012) foram anotadas as espécies ocorrentes no sentido horizontal da transecção até a altura de um metro (MUELLER-DOMBOIS; ELLENBERG, 1974). Para isto foi estendida uma linha de um extremo a outro da transecção, a um metro acima do nível do solo, e as espécies que se encontravam sob esta linha foram consideradas no transecto (CANFIELD, 1941) (Figura 4.2). A visualização da projeção vertical da linha foi construída com uma armação de três varetas de um metro, sendo duas verticais ligadas por uma horizontal.

Na projeção de cada unidade amostral, foram anotados os nomes científicos das espécies presentes, ou os nomes vulgares quando havia dúvidas quanto à identificação taxonômica. O estrato herbáceo, ou rasteiro, compreendeu todos os indivíduos com menos de um metro de altura (MUELLER-DOMBOIS; ELLENBERG, 1974), de espécies de diferentes hábitos, incluindo os indivíduos jovens de hábito arbóreo e arbustivo que ainda não tinham atingido o tamanho mínimo necessário para a inclusão na camada arbóreo- 
arbustiva. Assim, todas as espécies do componente herbáceo foram classificadas, por meio de literatura e observações de campo, conforme o hábito em: ervas (planta não lenhosa e terrestre), subarbustos (planta de base lenhosa e ápice herbáceo), trepadeiras (planta de hábito escandente de forma ampla), arbustos (planta lenhosa ramificada desde a base) (POLISEL, 2011) e árvores (planta lenhosa) (SILVA JR., 2005).

Nos levantamentos florísticos de 1988 até 1994 foram feitas coletas de material botânico e depósito no Herbário da Universidade de Brasília (UB), Herbário do Jardim Botânico de Brasília - Ezechias Paulo Heringer (HEPH), Herbário da Reserva Ecológica do IBGE e da Embrapa Recursos Genéticos e Biotecnologia - CENARGEN (CEN), em Brasília, Distrito Federal. As espécies férteis coletadas de 2012 a 2015 foram depositadas no Herbário da Universidade de Brasília (UB).

\subsubsection{Análise dos dados}

A composição florística foi fundamentada com a inclusão de espécies amostradas nas linhas (transecções), na Área 1 e na Área 2, nos anos de 1988 a 1994, antes do fogo acidental de agosto de 1994, e em 2012. A lista de espécies foi feita para cada ano, de acordo com APG III - The Angiosperm Phylogeny Group (CHASE; REVEAL, 2009). As espécies foram identificadas por meio de consultas a especialistas, literatura e comparação com exsicatas de Herbários. Para a conferência dos nomes científicos foi consultado o Missouri Botanical Garden (TROPICOS, 2015) e a Lista de Espécies da Flora do Brasil (FLORA..., 2015).

A composição florística foi analisada nas diferentes ocasiões de amostragem (1988 a 1994 e 2012). O número de espécies foi obtido em cada uma das ocasiões e em cada área (Área 1 e Área 2). Assim, para verificar se a riqueza diminuiu com a ocorrência de queimadas prescritas bienais, de 1988 a 1994, bem como se aumentou após um período de proteção contra o fogo, entre os anos de 1994 a 2012, os dados foram comparados por meio do teste de $\chi^{2}$ (qui quadrado) (SOKAL; ROHLF, 2009). O número de espécies de acordo com o hábito (árvore, arbusto, subarbusto, erva, trepadeira) também foi comparado nas diferentes ocasiões pelo teste de $\chi^{2}$. As análises foram feitas no software Excel 2010 do Windows. A curva espécie área, através da permutação dos dados originais, foi gerada para avaliar a suficiência da amostragem em relação à riqueza de espécies utilizando o software PC-ORD 5.0 (MACCUNE; MEFFORD, 2006). 
A similaridade entre as duas áreas (Área 1, Área 2), nos períodos de amostragem (1988 a 1994 e 2012), foi analisada utilizando o Método de Ligação Média Não Ponderada (UPGMA), que expressa por meio de um dendrograma as relações de similaridades entre as áreas. $\mathrm{O}$ dendrograma com base na presença e ausência das espécies empregou o índice de Jaccard (VALENTIN, 2000). Foram construídas matrizes com dados de presença e ausência das espécies para cada ano, nas duas áreas. O coeficiente de correlação cofenética foi calculado como uma medida de concordância entre os agrupamentos formados e a matriz original (BUSSAB et al., 1990). As análises foram feitas no programa FITOPAC 2.1 (SHEPHERD, 2010).

A diversidade de espécies entre as duas áreas (Área 1, Área 2) foi comparada empregando Perfis de Diversidade, usando a série exponencial de Rényi (TÓTHMÉRÉSZ, 1995), no programa PAST 2.08 (HAMMER et al., 2001). Com isto foi possível observar graficamente a diversidade sob diferentes pesos dados às espécies raras (LEINSTER; COBBOLD, 2012).

$\mathrm{Na}$ descrição da estrutura da comunidade do estrato herbáceo, com base nos dados dos levantamentos, foram feitos cálculos da frequência em todos os anos. A frequência pode ser calculada por meio do registro de ocorrência de cada espécie nas unidades amostrais (MUNHOZ; FELFILI, 2008). A partir dos dados da presença e ausência de espécies, obtidos pelo método de interceptação na linha, foram calculadas as frequências absoluta e relativa nas duas áreas (Área 1, Área 2) e, em 8 ocasiões (1988, 1989, 1990, 1991, 1992, 1993, 1994, 2012).

Os valores de frequência das espécies foram calculados no Microsoft Office Excel 2010, do Windows, usando as seguintes fórmulas (MEIRELLES et al., 2002; MUNHOZ; ARAÚJO, 2011):

Frequência Absoluta: $\mathrm{FA}_{\mathrm{i}}=\left(\mathrm{n}_{\mathrm{i}} / \mathrm{n}\right) .100$. Frequência Relativa: $\mathrm{FR}_{\mathrm{i}}=$ $\left(\mathrm{FA}_{\mathrm{i}} / \sum \mathrm{FA}_{\mathrm{i}}\right) .100$. Onde: $\sum \mathrm{FA} \mathrm{A}_{\mathrm{i}}=$ somatório da frequência absoluta de todas as espécies. Onde: $\mathrm{n}_{\mathrm{i}}=$ número de unidades amostrais (UA's) onde a espécie (i) ocorreu e; n= número total de UAs amostradas.

As frequências relativas de cada espécie ao longo do tempo (1988 a 2012) foram comparadas entre as duas áreas, bem como para cada área, ao longo do tempo, pareando as espécies a cada dois anos, pelo teste não paramétrico de Kolmogorov-Smirnov (ZAR, 2009), em um nível de significância de 5\%. Para verificar diferenças na distribuição das espécies de acordo com o hábito (árvore, arbusto, erva, subarbusto, trepadeira) as frequências relativas também foram comparadas para cada ano, entre as duas áreas, bem 
como para cada área, ao longo do tempo, pareando as amostras a cada dois anos, pelo teste não paramétrico de Kolmogorov-Smirnov (ZAR, 2009), em um nível de significância de 5\%. O programa PAST versão 2.15 (HAMMER et al., 2001) foi utilizado nestas análises.

\subsection{RESULTADOS}

Nas duas áreas houve acréscimo no número de espécies de 1988 a 1994, e em 2012 houve redução, quando comparado a 1994 (Tabela 4.2). Na área com queimadas bienais, Área 1, foram registradas, ao longo de todo período de estudo, um total de 184 espécies e 134 gêneros, distribuídos em 59 famílias botânicas. O menor número de espécies (92) foi observado em 1988 (Tabela 4.2) e aumentou até 1993, quando foram observadas 134 espécies. Em 2012 houve redução para 115 espécies. Das 92 espécies que foram registradas em 1988, 15 não ocorreram em 1994, e 25 em 2012. O número de famílias variou de 39 a 52, e o número de gêneros, de 76 a 106.

Tabela 4.2 - Número de famílias, gêneros e espécies, em duas áreas de Cerrado sentido restrito, com diferentes históricos de fogo, em Planaltina (DF), em 8 ocasiões de amostragem, onde: $1=1988,2=1989,3=1990,4=1991,5=1992,6=1993,7=1994,8=2012$; Área 1 = com queimadas bienais em 1988, 1990 e 1992, e proteção do fogo de 1995 a 2012; Área 2 = protegida da ação do fogo de 1988 a 1994 (julho), e de 1995 a 2012.

\begin{tabular}{lllllllll|llllllll}
\hline & \multicolumn{1}{c|}{ Área 1 } & \multicolumn{8}{c}{ Área } \\
& $\mathbf{1}$ & $\mathbf{2}$ & $\mathbf{3}$ & $\mathbf{4}$ & $\mathbf{5}$ & $\mathbf{6}$ & $\mathbf{7 *}$ & $\mathbf{8}$ & $\mathbf{1}$ & $\mathbf{2}$ & $\mathbf{3}$ & $\mathbf{4}$ & $\mathbf{5}$ & $\mathbf{6}$ & $\mathbf{7 *}$ & $\mathbf{8}$ \\
\hline Famílias & 39 & 44 & 45 & 44 & 51 & 52 & 50 & 43 & 38 & 43 & 41 & 42 & 43 & 45 & 46 & 39 \\
Gêneros & 76 & 92 & 102 & 94 & 106 & 106 & 104 & 87 & 82 & 89 & 93 & 93 & 102 & 103 & 102 & 84 \\
Espécies & 92 & 108 & 124 & 115 & 130 & 134 & 132 & 115 & 97 & 104 & 112 & 119 & 126 & 127 & 129 & 106 \\
\hline
\end{tabular}

*Obs.: o levantamento dos dados, em 1994, foi feito antes do fogo acidental que atingiu as duas áreas em agosto.

Na Área 1, com um fogo acidental em agosto de 1994, e 18 anos protegida contra o fogo, foram registradas, em todo período de estudo, 170 espécies, 126 gêneros e 52 famílias. O menor número de espécies (97) foi registrado em 1988 e o maior (129) em 1994. Nesta área, das 97 espécies observadas em 1988, 9 não ocorreram em 1994, e 28, em 2012. O número de gêneros variou de 82 a 103 e o de famílias de 38 a 46 . O número de espécies representadas por um único indivíduo, consideradas raras na área de estudo, variou nas duas áreas em todo o período, sendo 17 na Área 1, e 15 na Área 2, em 1994.

Com o período de exclusão do fogo, em 2012, houve aumento no número de espécies raras nas duas áreas, sendo 38 na Área 1 e 23 na Área 2 (Tabela 4.2). Com relação às espécies invasoras foram registradas quatro espécies de acordo com Mendonça et al. (2008). Cassytha filiformis foi observada na Área 1 até 2012, e na Área 2 até 1993. 
Schizachyrium condensatum foi observado nas duas áreas até 2012. Schizachyrium sanguineum foi registrado nas duas áreas até 1994. E Melinis minutiflora foi observada em 2012, na Área 2.

A curva espécie-área para o ano de 1988 nas duas áreas indica uma tendência à estabilização, considerando que com metade das unidades amostrais (100 linhas), cerca de 88\% das espécies foram amostradas na Área 1 (Figura 4.5). Na Área 2, 86\% das espécies foram amostradas com a metade das unidades amostrais (Figura 4.6). Desta forma, os resultados indicaram que a amostra foi suficiente para representar a riqueza florística na área.

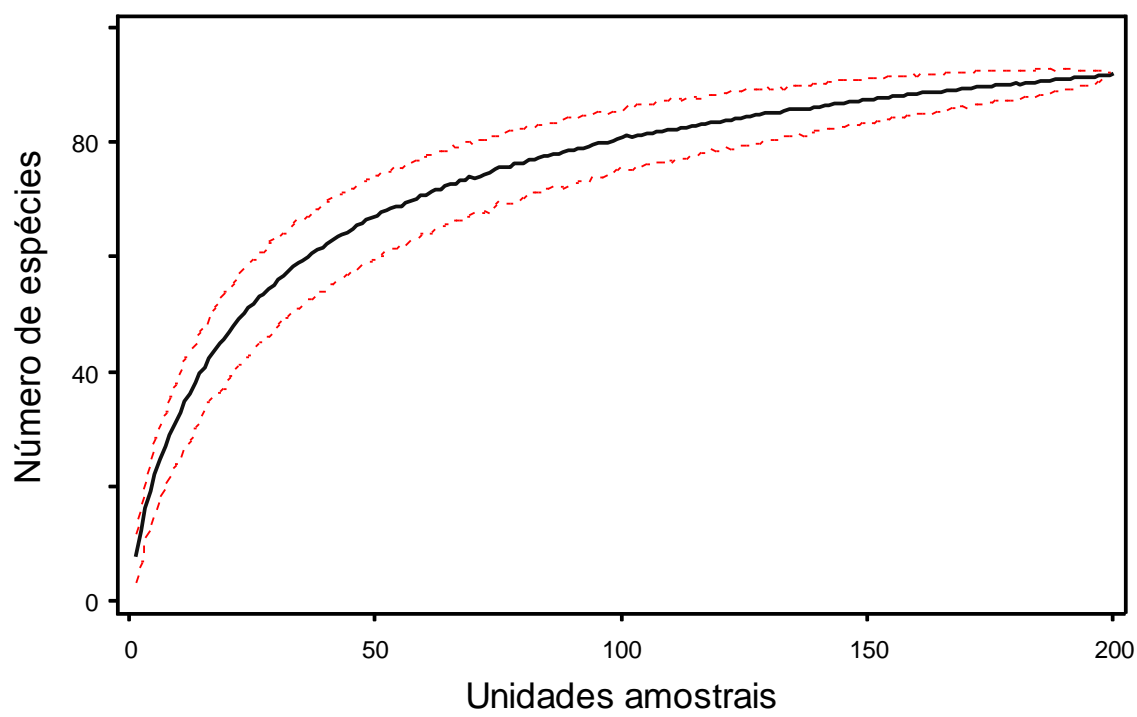

Figura 4.5 - Curva espécie-área das espécies do componente herbáceo de um Cerrado sentido restrito na Reserva Cerrado da Embrapa Cerrados, em Planaltina (DF), em 1988, na Área 1. A curva central representa o número de espécies estimadas; as curvas pontilhadas representam o desvio padrão. 


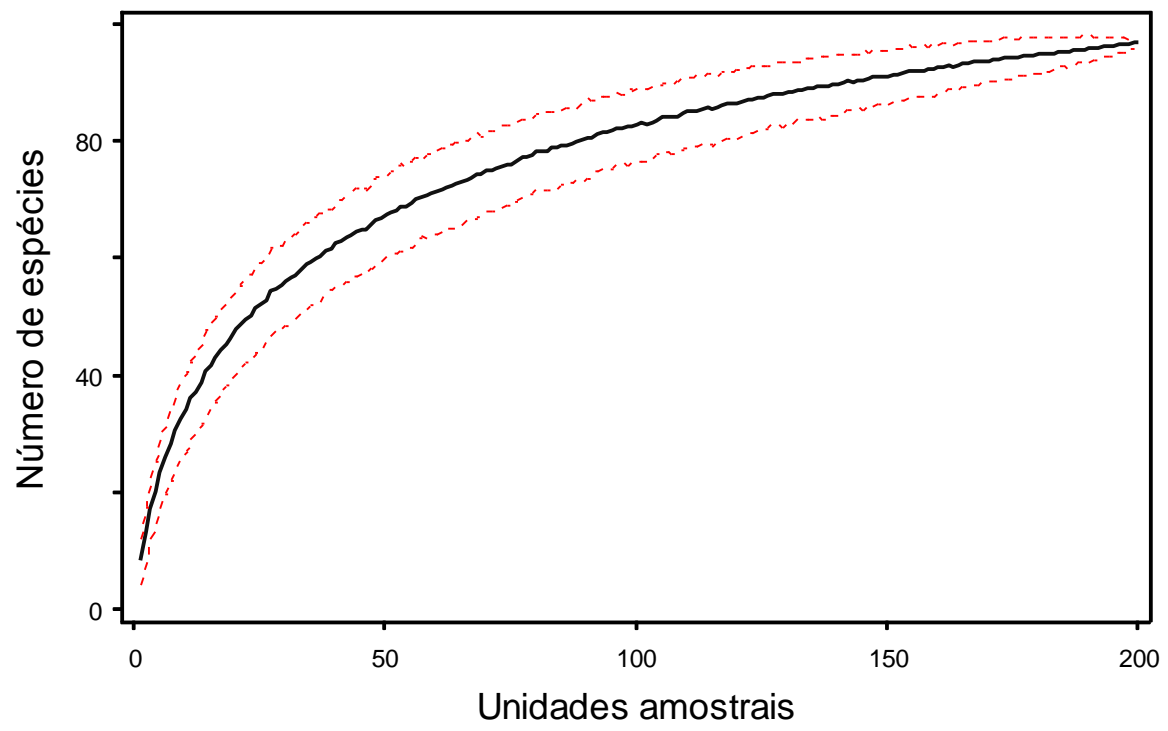

Figura 4.6 - Curva espécie-área das espécies do componente herbáceo de um Cerrado sentido restrito na Reserva Cerrado da Embrapa Cerrados, em Planaltina (DF), em 1988, na Área 2. A curva central representa o número de espécies estimadas; as curvas pontilhadas representam o desvio padrão.

Com relação à riqueza de espécies, os testes de $\chi^{2}$ não mostraram diferenças significativas $(\mathrm{p}>0,05)$ no número de espécies tanto com a aplicação de queimadas bienais no período de 1988 a 1994, quanto com a exclusão do fogo, de 1995 a 2012. Nas duas áreas (Área 1 e Área 2), de 1988 a 1994, as plantas de hábito arbóreo apresentaram o maior número de espécies ao longo de todo tempo, seguido das espécies subarbustivas e ervas (Figura 4.7; Apêndice 6). No entanto, não houve diferenças significativas ( $p>0,05)$, pelo teste de $\chi^{2}$, no número de espécies para cada forma de vida entre as duas áreas, comparando-se 1988 aos outros anos (1989 a 2012), e comparando-se 1994 com 2012. 

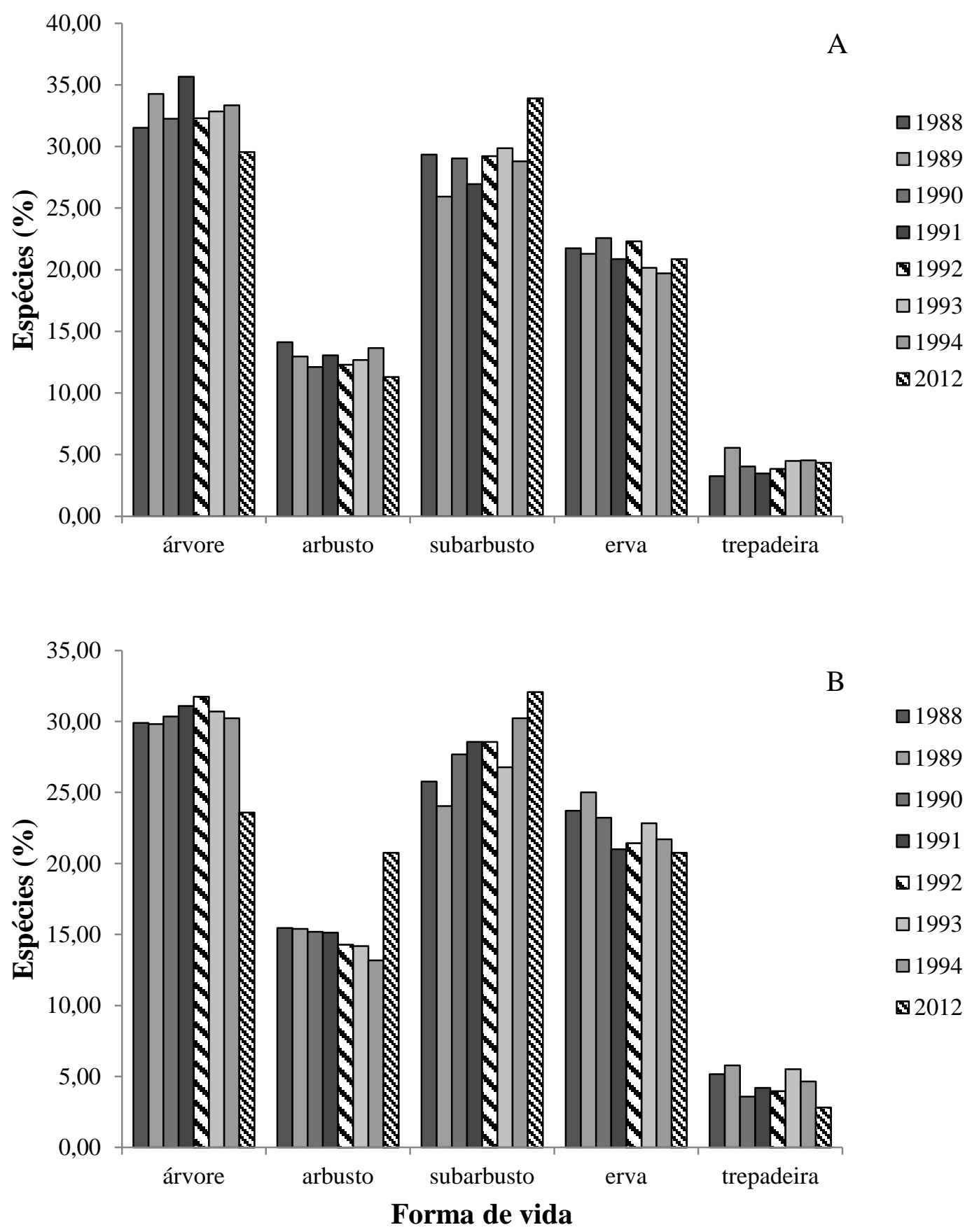

Figura 4.7 - Porcentagem de espécies de acordo com a forma de vida em duas áreas de Cerrado sentido restrito com diferentes históricos de fogo, em oito ocasiões, onde: $A=$ Área 1, com queimadas bienais em 1988, 1990 e 1992, e proteção do fogo de 1995 a 2012; B= Área 2, com proteção contra a ação do fogo de 1988 a julho de 1994, e de 1995 a 2012, e o levantamento dos dados, em 1994, antes do fogo acidental que atingiu as duas áreas em agosto.

Na camada herbácea da Área 1, de 1988 a 1994, o número de espécies de hábito arbóreo e arbustivo variou de 41 a 62, e de espécies herbáceas e subarbustivas variou de 50 
a 70. Na Área 2, de 1988 a 1994, o número de espécies de hábito arbóreo e arbustivo variou de 44 a 56, e de hábito herbáceo e subarbustivo, de 53 a 71. Na Área 1, em 1994, das 49 espécies registradas no estrato arbóreo-arbustivo (Capítulo 2), 9 não ocorreram no estrato rasteiro. Destas nove espécies, em 2012 somente uma, Qualea multiflora, não foi registrada no estrato arbóreo e apenas duas ocorreram no estrato herbáceo. Na Área 2, em 1994, das 50 espécies registradas no estrato arbóreo (Capítulo 2), oito não estavam presentes no estrato herbáceo. Em 2012, destas oito espécies somente Syagrus oleracea não foi encontrada no estrato arbóreo, e apenas Schefflera macrocarpa foi registrada no estrato herbáceo. E na Área 1, em 2012, com a proteção contra o fogo, das 68 espécies registradas no estrato arbóreo, 41 ocorreram no estrato rasteiro. Já na Área 2, das 63 espécies registradas no estrato arbóreo, 35 estavam presentes no estrato herbáceo.

As famílias com maior riqueza de espécies na Área 1, de 1988 a 2012, foram Fabaceae, Poaceae, Myrtaceae, Asteraceae e Bignoniaceae (Figura 4.8; Apêndice 6). Na Área 2, de 1988 a 2012 as familias mais ricas em espécies foram, principalmente, Fabaceae, Poaceae, Myrtaceae, Asteraceae, Bignoniaceae (Figura 4.8; Apêndice 6). Mas, em 1994, na Área 2, a família Rubiaceae também esteve entre as cinco mais importantes. O número de famílias com apenas uma espécie variou ao longo do tempo, sendo que na Área 1 eram 23 (em 1988), 27 (em 1994) e 20 (em 2012). Na Área 2 eram 20 (em 1988), 24 (em 1994), e 16 (em 2012). 

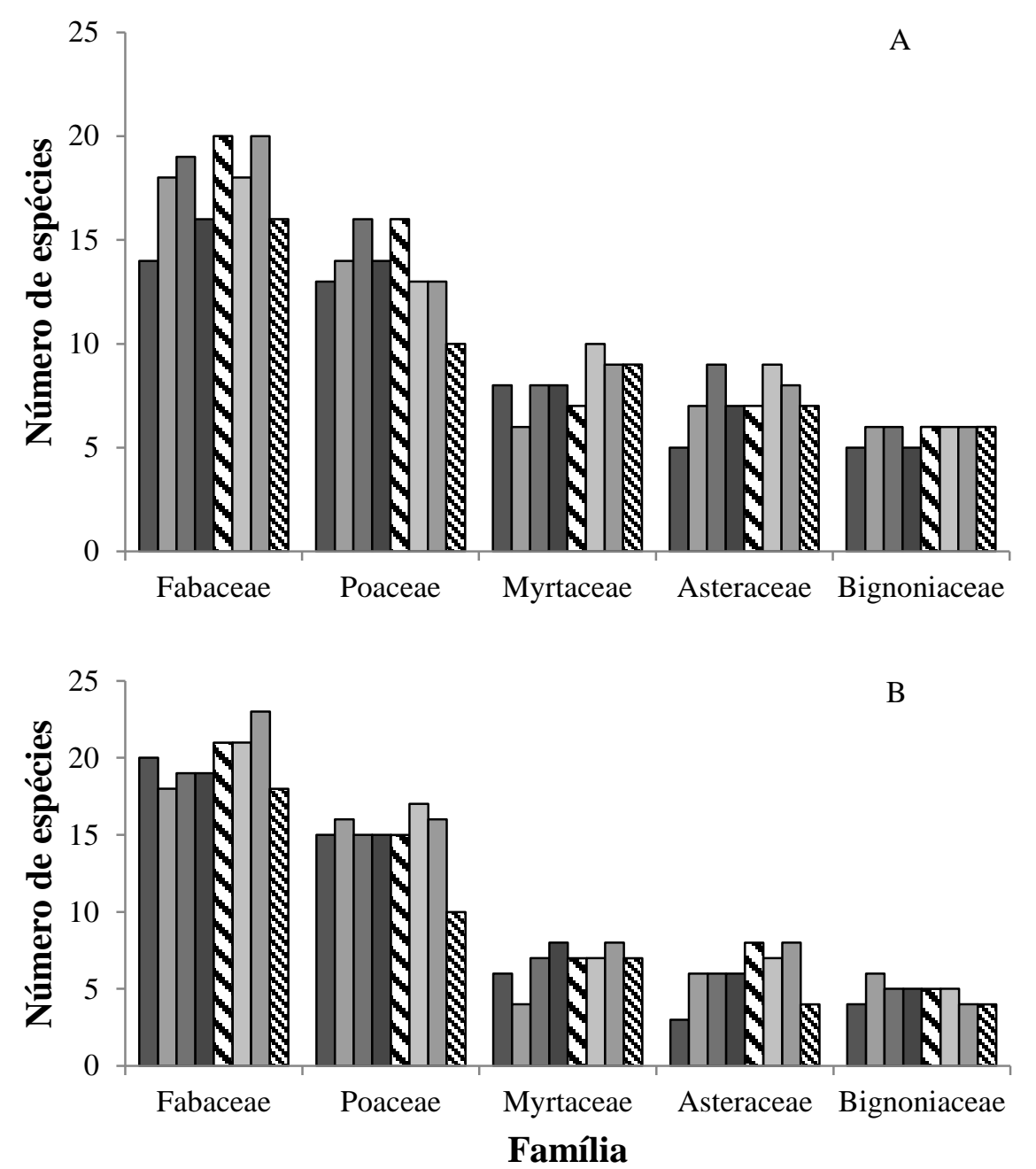

Figura 4.8 - Famílias com maior número de espécies do estrato herbáceo, em duas áreas de Cerrado sentido restrito, com diferentes históricos de fogo, em oito ocasiões do levantamento florístico, sendo: A= Área 1, com queimadas bienais em 1988, 1990 e 1992, e proteção do fogo de 1995 a 2012; B= Área 2, com proteção contra a ação do fogo de 1988 a julho de 1994, e de 1995 a 2012, e o levantamento dos dados, em 1994, antes do fogo acidental que atingiu as duas áreas em agosto.

A análise de agrupamento, pelo índice de Jaccard, com a finalidade de observar diferenças na similaridade florística durante o período de monitoramento, indicou a formação de três grupos distintos. Porém, em outros quatro anos não houve formação de grupos, pois ficaram isolados, mostrando menor similaridade em relação à composição de espécies. O Grupo A é formado pela Área 1, de 1990 a 1994, onde houve aplicação de queimadas bienais; o Grupo B, pela Área 2, de 1990 a 1994; e o Grupo C, pela Área 1 e Área 2 no ano de 1989. Em 1988 as duas áreas não apresentaram similaridade florística, ficando separadas. Em 2012 as duas áreas também ficaram separadas, mostrando diferenças na similaridade. O coeficiente de correlação cofenética de 0,94 é considerado 
elevado, demonstrando que pouco se perdeu da similaridade original com a elaboração do dendrograma (Figura 4.9).

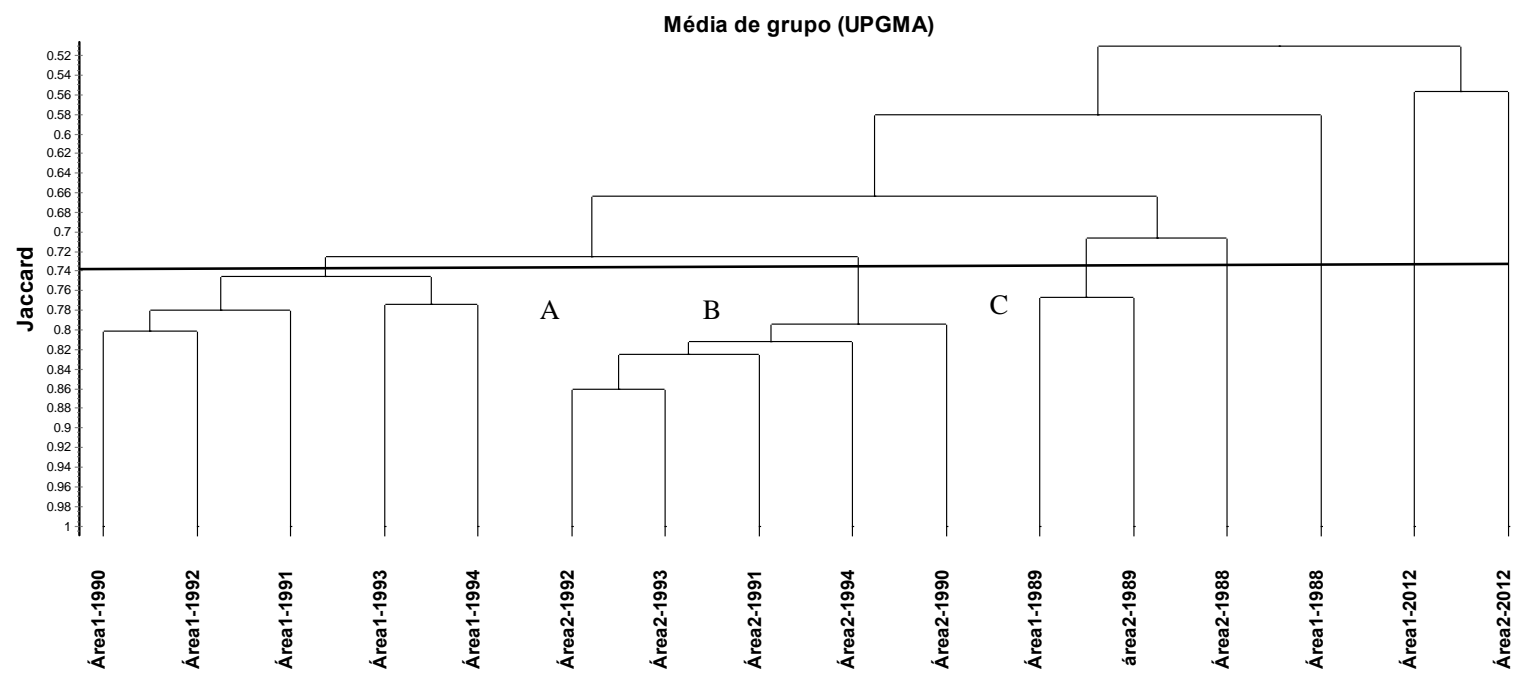

Figura 4.9 - Dendrograma de similaridade pelo método UPGMA, de acordo o índice de Jaccard, em duas áreas de Cerrado sentido restrito, em Planaltina (DF). Divisão em 3 grupos, sendo A = Área 1, de 1990 a 1994; B= Área 2, de 1990 a 1994; e C = Área 1 e Área 2, em 1989. Em 1988 (Área 1 e Área 2) e em 2012 (Área 1 e Área 2) não houve formação de grupos. Correlação cofenética $=0,94$. Obs.: Área1 $=$ com queimadas bienais em 1988, 1990, 1992, proteção do fogo de 1995 a 2012; Área2= com proteção contra a ação do fogo de 1988 a julho de 1994, e de 1995 a 2012, e o levantamento dos dados, em 1994, antes do fogo acidental que atingiu as duas áreas em agosto.

Os perfis de diversidade mostraram variação na diversidade ao longo do tempo, sendo que, nas duas áreas, em 1988 a diversidade foi menor do que nos anos seguintes até 1994; 1994 foi o ano que apresentou a maior diversidade. Em 2012, a diversidade foi menor do que em 1994, nas duas áreas (Figura 4.10). 


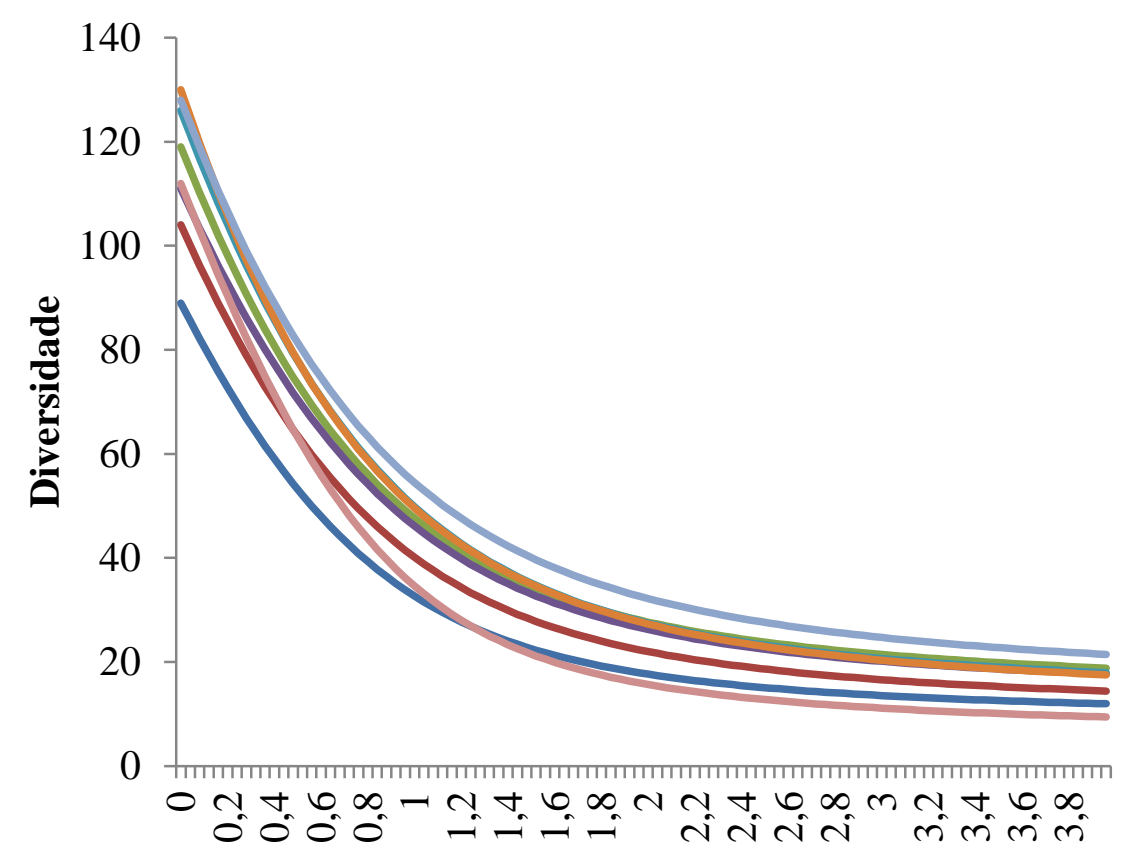

A

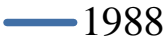

1989

$-1990$

$-1991$

1992

$-1993$

$-1994$

$-2012$

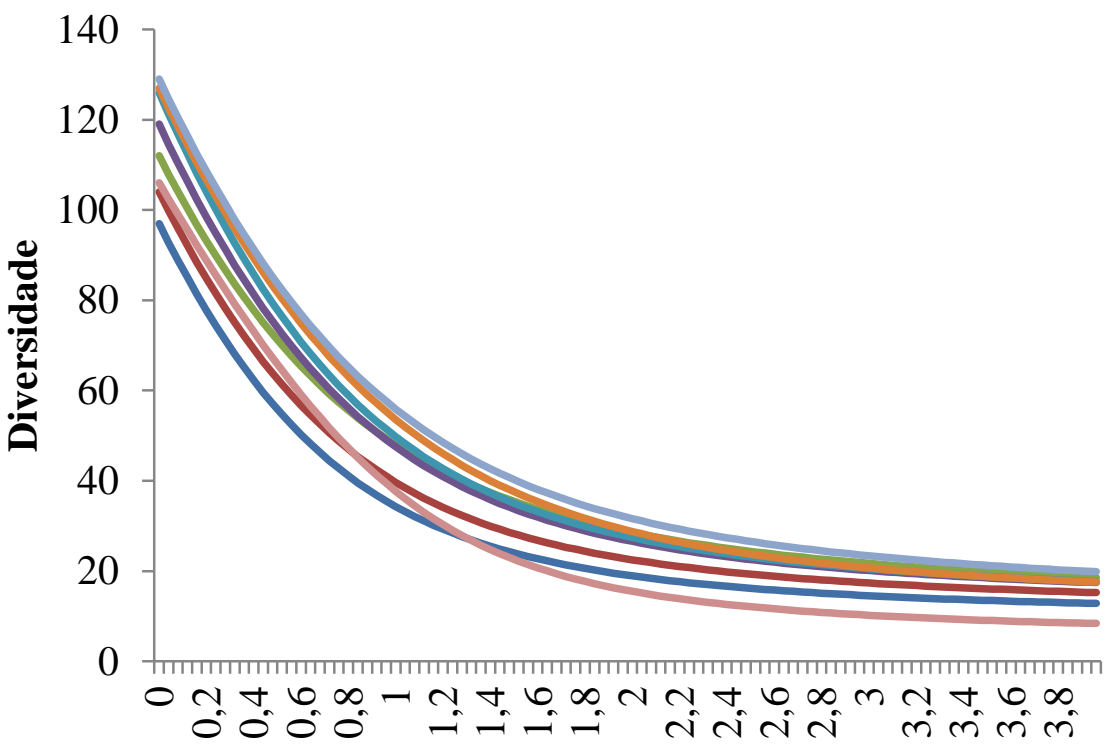

B

$-1988$

1989

$-1990$

1991

1992

$-1993$

$-1994$

$-2012$

Alfa

Figura 4.10 - Perfil de diversidade, utilizando a série exponencial de Rényi, das espécies do componente herbáceo de um Cerrado sentido-restrito em duas áreas, com diferentes históricos de fogo, na Reserva da Embrapa Cerrados, em Planaltina (DF), de 1988 a 2012, sendo: A = Área 1, com queimadas bienais em 1988, 1990, 1992, e proteção do fogo de 1995 a 2012; B= Área 2, protegida contra a ação do fogo de 1988 a julho de 1994, e de 1995 a 2012, e o levantamento dos dados, em 1994, antes do fogo acidental que atingiu as duas áreas em agosto.

Nas duas áreas, ao longo do tempo, houve variação nas frequências relativas das espécies e famílias (Figura 4.11; Figura 4.12; Apêndice 6). Com a aplicação do teste de Kolmogorov-Smirnov foram detectadas diferenças significativas $(\mathrm{p}<0,05)$ na distribuição das frequências relativas das espécies entre as duas áreas em 1989, bem como em 1993 e 
em 2012. Na área 1, em 1988, as 10 espécies com maior frequência relativa foram: Echinolaena inflexa, Schizachyrium tenerum, Axonopus barbigerus, Axonopus marginatus, Merremia digitata, Ruellia asperula, Bauhinia dumosa, Diplusodon oblongus, Myrsine guianensis e Croton campestris. Destas, quatro são da família Poaceae e sete estão entre as 10 com maior frequência relativa na Área 2 (Figuras 4.11 e 4.12). Na Área 2, em 1988, as 10 espécies com maior frequência relativa foram: Echinolaena inflexa, Axonopus barbigerus, Axonopus marginatus, Schizachyrium tenerum, Merremia digitata, Diplusodon oblongus, Myrsine guianensis, Elionorus muticus, Trachypogon sp e Casearia altiplanensis. Nas duas áreas as quatro espécies de Poaceae apresentaram maior frequência relativa.

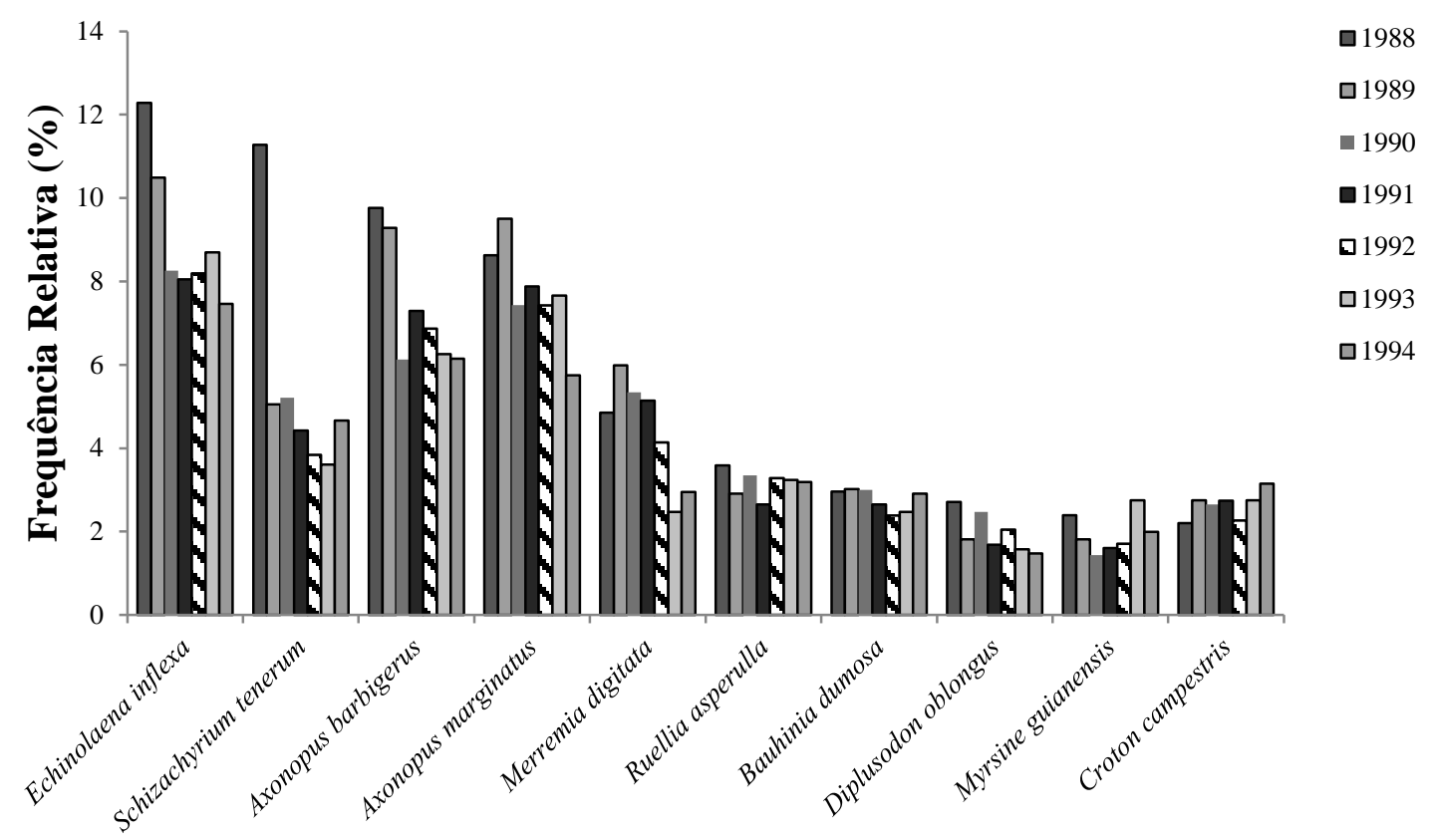

Espécies

Figura 4.11 - Variação da Frequência Relativa (\%) das dez espécies com maiores valores em um Cerrado sentido restrito, em Planaltina-DF, na Área 1 em 1988, comparado aos valores registrados de 1989 a 1994. 


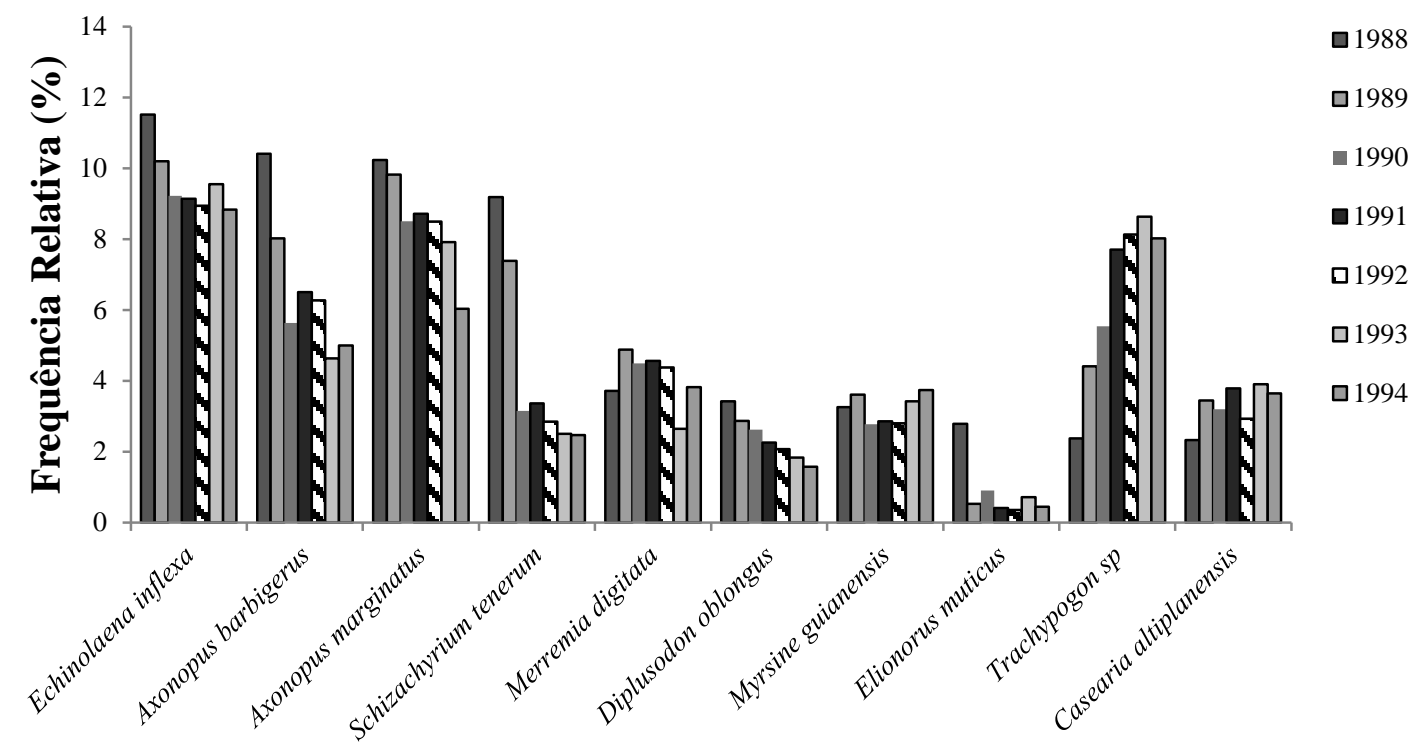

\section{Espécies}

Figura 4.12 - Variação da Frequência Relativa (\%) das dez espécies com maiores valores em um Cerrado sentido restrito, em Planaltina (DF), na Área 2 em 1988, comparado aos valores registrados de 1989 a 1994.

Na Área 1 as famílias Poaceae, Fabaceae, Convolvulaceae e Euphorbiaceae ficaram entre as cinco famílias com maiores valores de frequência relativa até 1994, somando 65\% em 1988 e 56\% em 1994 (Apêndice 6). As famílias Fabaceae e Poaceae também aparecem entre as cinco famílias mais importantes até 2012, somando 56\% em 1988, 48\% em 1994 e 52\% em 2012. Na Área 2, as cinco famílias com maiores valores de frequência relativa variaram ao longo do tempo e somaram entre $61 \%$ e $70 \%$. As Famílias Poaceae e Fabaceae ficaram entre as cinco com os maiores valores, somando entre $46 \%$ a $59 \%$ da frequência relativa, de 1988 a 2012.

Com relação à frequência relativa das espécies de acordo com o hábito, nas duas áreas, ervas e subarbustos tiveram maior frequência relativa em todos os anos (Figura 4.13). Árvores, arbustos e trepadeiras foram menos frequentes. O teste de KolmogorovSmirnov não mostrou diferenças significativas $(p>0,05)$ na distribuição das frequências tanto de acordo com o hábito (árvore, arbusto, subarbusto, erva, trepadeira) em cada área ao longo do tempo quanto entre as duas áreas, ao longo do tempo de estudo. 


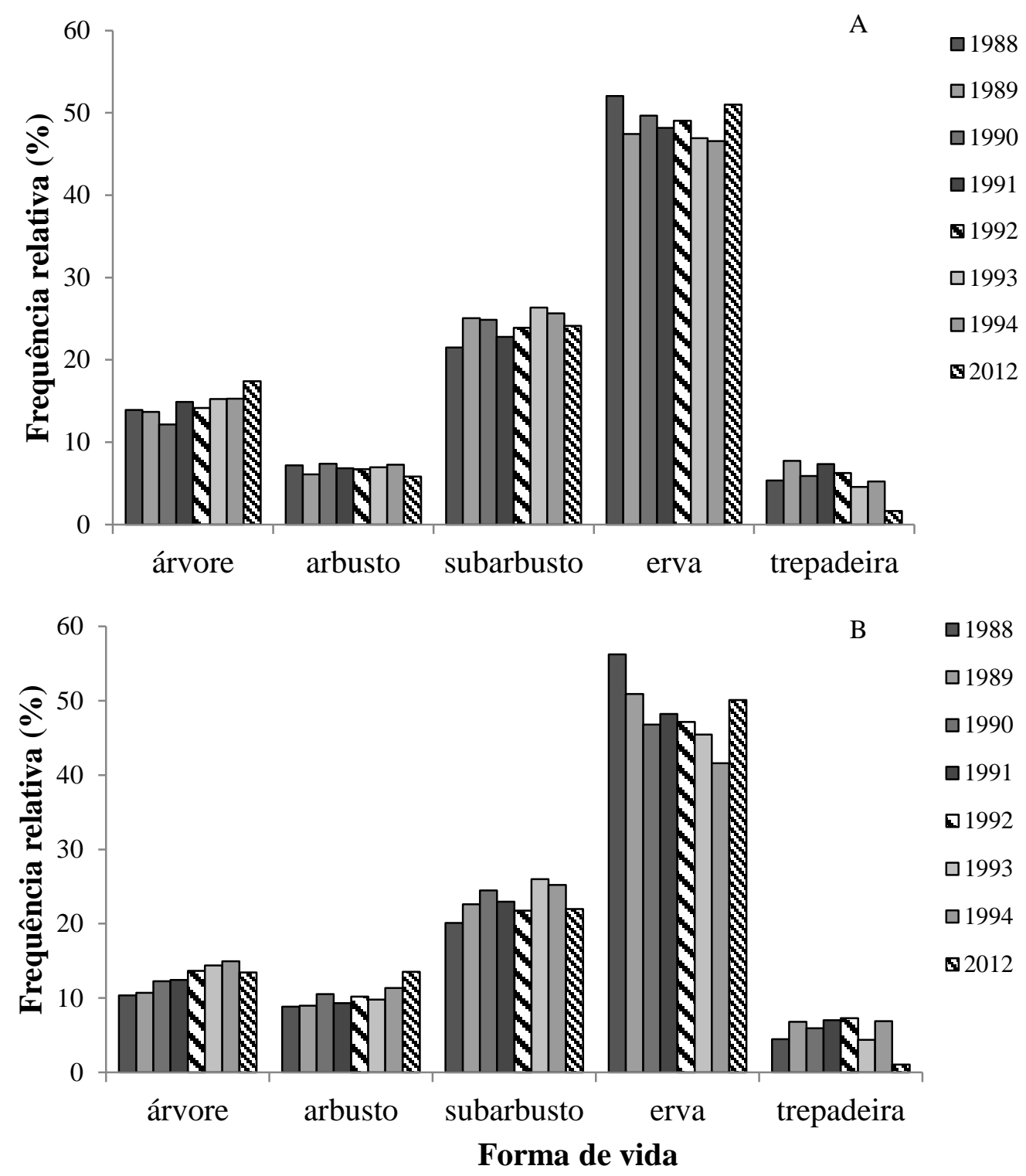

Figura 4.13 - Frequência relativa (\%) do componente herbáceo, de acordo com o hábito, em duas em duas áreas de Cerrado sentido, com diferentes históricos de fogo, em oito ocasiões do levantamento florístico; sendo: A= Área 1, com queimadas bienais em 1988, 1990 e 1992, e proteção do fogo de 1995 a 2012; B= Área 2, protegida contra a ação do fogo de 1988 a julho de 1994, e de 1995 a 2012, e o levantamento dos dados, em 1994, antes do fogo acidental que atingiu as duas áreas em agosto.

\subsection{DISCUSSÃO}

O número de espécies do estrato herbáceo foi próximo ao mencionado para o Cerrado sentido restrito em algumas áreas no Distrito Federal (CASTRO-NEVES, 2007; BRAGA, 2010), mas diferente do encontrado em estudos no Maranhão e São Paulo (MEIRELLES et al., 2002; BATALHA; MANTOVANI, 2001). Na Reserva Ecológica do IBGE-DF, Castro-Neves (2007) registrou 128 espécies no estrato herbáceo, sendo 48 de 
hábito arbóreo e arbustivo. Braga (2010) encontrou, no Jardim Botânico de Brasília-DF, 82 espécies entre ervas e subarbustos, também utilizando o método de interceptação na linha. Já Lima (2015), em uma área de transição entre vegetação nativa e área em processo de recuperação do Instituto Nacional de Meteorologia (INMET), registrou 64 espécies de hábito herbáceo, subarbustivo e arbustivo, também pelo método de interceptação na linha. E, na Fazenda Água Limpa-DF, em estudos da regeneração, de indivíduos arbóreos menores de um metro, Medeiros et al. (2007) registraram 49 espécies.

Em outra área, fora do Distrito Federal, na Reserva Legal no Município de Balsas (MA), os resultados foram inferiores aos obtidos neste estudo, pois Meirelles et al. (2002), pelo método de interseção na linha, registraram entre 58 e 73 espécies do estrato herbáceo, incluindo todos indivíduos com menos de um metro de altura. Por outro lado, os resultados da Reserva da Embrapa Cerrados foram inferiores aos da Reserva Pé-de-Gigante, em Santa Rita do Passa Quatro (SP), onde Batalha e Mantovani (2001) encontraram 194 espécies herbáceas, por meio de excursões mensais durante 18 meses. As diferenças observadas em algumas áreas, possivelmente, são em decorrência da variação na composição florística de espécies herbáceas em áreas de Cerrado (FILGUEIRAS, 2002), mas também podem estar relacionadas às diferenças climáticas, aos fatores físicos e químicos do solo (MUNHOZ; FELFILI, 2006) e à metodologia empregada.

A modificação na riqueza de espécies herbáceas pode ser observada tanto ao longo dos anos quanto em um mesmo ano (SILVA; NOGUEIRA, 1999; MUNHOZ; FELFILI, 2008; EUGÊNIO et al., 2011). Alguns estudos com vegetação herbácea relatam a necessidade de mais de um levantamento por ano para aumentar as chances da amostragem de espécies, principalmente, daquelas com ciclo de vida curto (SILVA; NOGUEIRA, 1999; MUNHOZ; FELFILI, 2008). A importância do maior número de amostragens ao longo do ano foi evidenciada no estudo de Silva e Nogueira (1999), onde o número de espécies arbustivo-herbáceas registradas onze meses após o fogo, durante o período de estiagem, foi similar ao observado um mês após incêndio acidental, em Cerrado sentido restrito no Distrito Federal. No caso da Reserva Cerrado da Embrapa Cerrados, o monitoramento do estrato herbáceo foi realizado somente uma vez por ano, no período seco; não foi feito logo após o fogo, não havendo, portanto, registro da variação no número de espécies ao longo do ano.

Os resultados anuais de riqueza não mostraram diferenças significativas no número de espécies do estrato herbáceo durante o período de 1988 a 1994, com queimadas bienais, e após 18 anos de proteção contra o fogo, e desta forma, estes resultados podem ser um 
indicativo da recuperação um ano após as queimadas e da resiliência da comunidade diante do distúrbio. Além disso, o fato da maioria das espécies herbáceas que ocorrem no Cerrado serem altamente resilientes, e, possuírem certas adaptações ao fogo, apresentando baixa mortalidade, além de floração e brotação vigorosas poucos dias ou semanas após a passagem das queimadas (COUTINHO, 1990) pode justificar a manutenção de algumas espécies na área e o aumento no número de espécies registrado durante o período com queimadas.

Após 18 anos sem fogo, em 2012, o número de espécies do estrato herbáceo reduziu nas duas áreas em relação ao último levantamento de 1994. A proteção da área não modificou a riqueza de espécies do estrato arbóreo-arbustivo de forma significativa, no entanto, favoreceu o aumento da densidade destas espécies (Capítulo 2) e, consequentemente, o aumento da cobertura destas espécies, pode ter levado à redução da cobertura de ervas e subarbustos (GARDNER, 2006; EUGÊNIO et al., 2011) e ao empobrecimento no número de espécies da vegetação do estrato rasteiro (MUNHOZ; AMARAL, 2010). É importante lembrar que em 1994 um incêndio acidental atingiu as duas áreas, e, em anos mais recentes tem havido o pisoteio de gado bovino, bem como, a pressão antrópica devido às construções de condomínios e assentamentos rurais em áreas próximas à reserva que também podem ter influenciado a redução de espécies nas duas áreas.

As famílias Fabaceae, Poaceae, Myrtaceae e Asteraceae, que se destacaram pelo maior número de espécies, também estão entre as famílias com maior riqueza de espécies em outros estudos no DF e em outras regiões. A importância de Fabaceae no Cerrado pode ser atribuída à capacidade de fixação biológica de nitrogênio de muitas espécies, o que facilita a regeneração em solos pobres e degradados (SOUZA et al., 2010; SILVA; FELFILI, 2012). Também em Cerrado sentido restrito, no Jardim Botânico de Brasília-DF (BRAGA, 2010) e na Reserva Ecológica do IBGE-DF (SILVA; NOGUEIRA, 1999) as famílias com maior número de espécies foram atribuídas à Fabaceae, Poaceae, Myrtaceae e Asteraceae.

As famílias Asteraceae, Fabaceae e Poaceae também estavam entre as mais ricas em outras regiões, como por exemplo, no estudo do componente herbáceo da flora na Reserva Biológica de Mogi Guaçu-SP (MANTOVANI; MARTINS, 1993) e no Parque Nacional de Emas-GO (BATALHA; MARTINS, 2007). Algumas pesquisas mostram que a flora do Cerrado é composta por poucas famílias com um grande número de espécies e por muitas famílias com uma espécie (BATALHA; MANTOVANI, 2000), confirmando, 
assim, os registros de um grande número de famílias com uma espécie apenas, durante o período de estudos, nas duas áreas da Embrapa Cerrados.

As duas áreas estudadas na Reserva Cerrado da Embrapa Cerrados, apresentaram similaridade florística somente em 1989, um ano após a primeira queimada. Neste ano muitas espécies apareceram na Área 1, com queimadas, e outras não foram registradas, mas, possivelmente, devido ao grande número espécies comuns às duas áreas, 92 espécies, foi observada maior similaridade florística. Nos outros anos não houve similaridade florística entre as duas áreas, sendo observadas variações na composição florística. As diferenças na composição florística entre as duas áreas ocorreram sem que houvesse mudanças na riqueza, uma vez que, algumas espécies excluídas foram substituídas por novas espécies (WHELAN, 2002). Após o fogo, o estrato herbáceo tem uma regeneração rápida (MIRANDA, 2002) e, durante o processo de recolonização, com o aumento de espécies mais abundantes e o aparecimento de plântulas ocupando os espaços abertos (MIRANDA, 2002) algumas espécies foram favorecidas, provocando assim, as diferenças na similaridade florística entre as duas áreas, no período de 1990 a 1994. Em 2012, dentre as espécies favorecidas podem ser mencionados os subarbustos Peixotoa cordistipula, Bidens graveolens, Eriosema defoliatum e Kielmeyera abdita, dentre outros, que foram registrados após a queimada de 1988.

O fogo, geralmente, favorece as plantas herbáceas no Cerrado (FILGUEIRAS et al., 1998; LOIOLA et al., 2010), mas a recuperação da vegetação herbácea pode variar com a época e frequência das queimadas e com a composição das espécies (MIRANDA et al., 2010). Na Área 1, as queimadas bienais favoreceram a dominância de algumas espécies de hábito herbáceo e subarbustivo (MOREIRA, 2000; SILVA et al., 2011), mas diminuíram a frequência das gramíneas (CARDOSO et al., 2000b) de forma geral. Por exemplo, Croton campestris, subarbusto, também foi favorecido, aumentando a frequência ao longo do período com queimadas. Já Casearia altiplanensis, um subarbusto, apresentou maiores valores de frequência, em todos os anos, em comparação a 1988, mas aumentava a frequência após as queimadas e reduzia após período de exclusão do fogo entre uma e outra queimada.

Por outro lado, Diplusodon oblongus, subarbusto, diminuiu a frequência relativa de 1988 a 1994. E, dentre as gramíneas, Echinolaena inflexa, Axonopus barbigerus e Axonopus marginatus tiveram redução da frequência relativa ao longo do período de estudo, e, Trachypogon sp foi favorecida com as queimadas, aumentou sua frequência ao 
longo do tempo, e foi considerada a segunda espécie com maior frequência relativa em 1994.

Com relação à diversidade, foram observadas mudanças ao longo do período de estudo em cada área, mas não houve diferenças entre as duas áreas em cada ano do monitoramento. Alguns trabalhos sugerem que as queimadas periódicas podem aumentar, diminuir ou manter a diversidade do componente herbáceo (SILVA; NOGUEIRA, 1999; SILVA, 2005; MUNHOZ et al., 2006; AMARAL, 2008), sendo complexa a determinação de um padrão. Nas duas áreas, em 1994, foi observada a maior diversidade, em comparação aos outros anos do monitoramento. A alta diversidade de espécies também foi observada na Reserva Ecológica do IBGE (DF), por Silva (2005), em duas áreas de Campo sujo, uma com queimada bienal em agosto e a outra protegida contra o fogo, no entanto, a maior diversidade ocorreu na área com fogo.

Já, em levantamentos durante o período chuvoso, em área de Campo sujo, na Reserva Ecológica do IBGE-DF, Miranda (2002) encontrou os menores valores de diversidade de gramíneas em áreas queimadas bienalmente. Silva e Nogueira (1999), em área de Cerrado sentido restrito que passou por incêndio após 18 anos de proteção, na Reserva Ecológica do IBGE (DF), observaram que no período de estiagem foram encontrados os maiores índices de diversidade e atribuíram estas diferenças à morte da parte aérea de ervas que apresentavam elevada dominância, levando à maior equitabilidade das espécies.

A dinâmica do estrato herbáceo segue a sazonalidade típica das savanas, sendo que, no período das chuvas, tem-se o aumento da biomassa das gramíneas e no período seco a biomassa aérea morre e seca em grande parte (KLINK; SOLBRIG, 1996), e, desta forma, a variação nos resultados de diversidade nestes locais também pode estar relacionado à época de coleta dos dados. Nas duas áreas da Reserva da Embrapa Cerrados, as amostragens foram feitas um e dois anos após a queimada, e, na época seca, provavelmente, com a mortalidade da parte aérea de algumas ervas dominantes, houve aumento da equitabilidade na Área 1, fazendo com que as duas áreas mostrassem diversidade similar ao longo do período de 1988 a 1994. Em 1994, que apresentou maior diversidade, 20 espécies somaram $64 \%$ da frequência relativa nas duas áreas e em 1988, o mesmo número de espécies somou $76 \%$. E desta forma, o aumento no número de espécies e a variação da abundância das espécies, com maior número de espécies com percentual mais elevado de frequência relativa em 1994, comparado a 1988, podem ter levado à distribuição mais homogênea das espécies e ao aumento da diversidade e equitabilidade. 
Com 18 anos sem fogo, as duas áreas apresentaram diversidade similar, mas menor do que em 1994. Esta redução na diversidade também pode estar relacionada à dinâmica da abundância das espécies com a exclusão do fogo. A exclusão do fogo pode influenciar a variação na cobertura de algumas espécies de Poaceae (MUNHOZ et al., 2006; AMARAL, 2008). E, com o aumento da cobertura de gramíneas pode haver o sombreamento do solo, aumento da competição entre as plantas e redução da floração de espécies heliófilas (COUTINHO, 1976; CARDOSO et al., 2000b; MUNHOZ; AMARAL, 2010).

Nas duas áreas da Reserva da Embrapa Cerrados não foi avaliada a cobertura das espécies, no entanto, os resultados mostraram redução na frequência relativa das espécies da família Poaceae nas duas áreas durante o período de queimadas de 1988 (49\% e $51 \%$ ) a 1994 (39 \% e $35 \%$ ). E, em 2012, com a exclusão do fogo, houve aumento da frequência relativa em comparação a 1994, com 45 \% na Área 1 e 43 \% na Área 2. A proteção da área contra o fogo levou ao aumento da dominância de Echinolaena inflexa, provavelmente, devido à exclusão de espécies menos competitivas (SILVA et al., 2011). Nas duas áreas houve aumento da frequência relativa de Echinolaena inflexa, de 1994 para 2012, sendo de $17 \%$ na Área 1 e $20 \%$ na Área 2. As espécies mais frequentes variaram nas duas áreas, no entanto, um pequeno número, 32 , somou cerca de $80 \%$ da frequência relativa em cada área, justificando, a menor equitabilidade e diversidade encontrada neste ano.

A distribuição das frequências relativas das espécies, de acordo com o hábito, não variou de forma significativa entre as duas áreas ao longo do tempo, no entanto, houve maior frequência de ervas e subarbustos. Os levantamentos foram realizados somente uma vez ao ano, e, desta forma, provavelmente, o tempo após as queimadas foi suficiente para a recuperação de várias espécies, principalmente, das mais resistentes. A maior frequência de ervas, com elevados percentuais de gramíneas, e de subarbustos nas duas áreas da Reserva da Embrapa Cerrados, deveu-se, possivelmente, ao favorecimento de algumas espécies que possuem órgãos subterrâneos ou bases foliares persistentes que protegem as gemas (MIRANDA et al., 2009), bem como à produção de flores, frutos e sementes ser mais rápida em muitas espécies do estrato herbáceo-subarbustivo do que em espécies arbóreoarbustivas (BARBOSA, 1997; ANDRADE; MIRANDA, 2010), garantindo a liberação das sementes na estação chuvosa seguinte à queimada, e recomposição da vegetação (ANDRADE; MIRANDA, 2010) até o período seco, quando foram feitos os levantamentos.

Cabe salientar que algumas espécies herbáceas também têm ciclo anual, crescem e se desenvolvem na estação chuvosa, e ainda como sementes, não são atingidas pelas 
queimadas da estação seca (COUTINHO, 1990; MISTRY, 1998). Com relação às espécies de hábito arbóreo e arbustivo, do componente herbáceo, o fogo provocou a morte e dificultou o estabelecimento de plântulas de algumas destas espécies (SILVA et al., 2011), principalmente das arbustivas, que mostraram maior sensibilidade diante do distúrbio e frequência relativa inferior à Área 2. A variação e a menor frequência relativa das espécies de hábito arbóreo e arbustivo, do componente rasteiro, em todos os anos, possivelmente, estão relacionados às características de algumas plântulas quanto à capacidade de sobreviver a queimadas recentes e de se reproduzir vegetativamente (HOFFMANN, 1998; MIRANDA; SATO, 2005; ANDRADE; MIRANDA, 2010). E dentro desse contexto, plântulas de algumas espécies da área estudada na Embrapa Cerrados, possivelmente, apresentaram rápido desenvolvimento do sistema radicular e a habilidade de rebrotar após as queimadas, atingindo o tamanho crítico de escape ao fogo (BRAZ et al., 2000; MIRANDA; SATO, 2005), no entanto, outras que não tinham essas características, foram mais facilmente atingidas pelas queimadas frequentes.

O fogo modificou a frequência das espécies, um ano após a primeira queimada, em 1989, e após a terceira queimada, em 1993. A proteção contra o fogo por 18 anos também modificou a frequência relativa das espécies. A primeira queimada de 1988, após cerca de 10 anos de exclusão deste distúrbio, modificou a frequência relativa das espécies, reduzindo a ocorrência da maioria das gramíneas, mas também de espécies de dicotiledôneas. O acúmulo de biomassa na camada superficial do solo, principalmente das gramíneas, aumenta a probabilidade de ignição, a intensidade e a extensão do fogo (CIANCIARUSO et al., 2010), e como a área da Reserva já estava protegida por pelo menos 10 anos, provavelmente, a queimada teve maior proporção neste ano (SILVA et al., 2011).

Deve-se salientar que, de forma geral, espécies de Poaceae apresentam maior cobertura relativa do que frequência relativa, o que pode ser devido à forma de crescimento das espécies que podem formar touceiras densas ou indivíduos rizomatosos ou estoloníferos amplamente espalhados na vegetação (MUNHOZ et al., 2006). Como as gramíneas aumentam a biomassa na estação seca, pelo acúmulo de biomassa durante a estação chuvosa e secam no período seco (PIVELLO et al., 2010; SILVA et al., 2011), provavelmente, na primeira queimada de agosto de 1988, havia grande cobertura de gramíneas na área.

A abertura de clareiras após as queimadas promove uma sucessão de espécies colonizadoras (MIRANDA; KLINK, 1996b) e o sucesso regenerativo está relacionado à 
capacidade de reprodução vegetativa, de produzir sementes rapidamente, bem como da sobrevivência das plântulas após queimadas recorrentes (HOFFMANN, 1998; WHELAN, 2002; MIRANDA; SATO, 2005). E, desta forma, as mudanças na frequência relativa, um ano após a primeira queimada, e após a terceira queimada, podem estar relacionadas ao fato do fogo favorecer algumas espécies do estrato herbáceo (MOREIRA, 2000), pelo estímulo da floração e produção de sementes de algumas espécies (SILVA et al., 2011), bem como pela capacidade de rebrota a partir de órgãos subterrâneos (COUTINHO, 1990), desenvolvimento de novos indivíduos a partir das sementes que sobreviveram à passagem do fogo (ANDRADE; MIRANDA, 2010) ou sobrevivência de plântulas de lenhosas na estação seca (MIRANDA; SATO, 2005).

$\mathrm{Na}$ área com fogo foram incluídas 30 espécies em 1989, sendo duas de gramíneas. A grande maioria dessas espécies se manteve ao longo do período com fogo, mas Gymnopogon spicatus e Bacharis subdentata não foram registradas de 1991 a 2012 e Brosimum gaudichaudii de 1993 a 1994. O fogo também pode eliminar algumas espécies mais sensíveis, sendo que das espécies que ocorreram em 1988, 14 também não foram registradas em 1989, sendo duas de Poaceae e 12 dicotiledôneas.

$\mathrm{Na}$ área da Reserva da Embrapa Cerrados em 1993, após três queimadas bienais, algumas espécies tiveram redução na frequência relativa, em relação ao ano anterior, e, das 134 espécies observadas neste ano, 30 tiveram apenas um registro de ocorrência. Outras espécies, como Simaba sp, Qualea multiflora e Agonandra brasiliensis apareceram somente em 1993. A capacidade de recuperação diante das queimadas bienais variou entre as espécies (WHELAN, 2002) e pode estar relacionada à história de vida das espécies com a presença do fogo (MIRANDA; KLINK, 1996a; WHELAN, 2002).

Os resultados obtidos enfatizam os efeitos das queimadas frequentes, que podem ter promovido a exaustão dos órgãos de reserva pelas sucessivas rebrotas, bem como ter prejudicado a floração de espécies mais sensíveis ao fogo (WHELAN, 2002; MIRANDA; SATO, 2005). Algumas espécies arbóreas e arbustivas, com capacidade para rebrotar, tiveram redução na frequência relativa no estrato herbáceo de 1992 para 1993, como Styrax ferrugineus e Guapira graciliflora. Esta redução também foi observada no número de indivíduos destas espécies recrutados em 1993 e 1994, no estrato arbóreo (Capítulo 2). Para G. graciliflora, foram recrutados oito indivíduos em 1992, nenhum em 1993 e dois em 1994. Já para S. ferrugineus foram recrutados nove em 1992, nenhum em 1993 e um em 1994. Campomanesia adamantium, Eugenia myrcianthes e Bauhinia rufa, dentre outras, também tiveram a frequência reduzida em 1993. Outras espécies aumentaram a 
frequência, como por exemplo, Spiranthera odoratissima que passou de 0,3\%, em 1988, para $0,8 \%$, em 1993, diminuindo nos anos seguintes, mas na Área 2 a frequência relativa foi menor, de 0,05\% em 1993.

A espécie Myrsine guianensis, apresentou uma dinâmica específica aliada à sua habilidade em rebrotar. Esta espécie que pode ter o sucesso reprodutivo por sementes limitado em queimadas bienais, por produzir poucas sementes e ter plântulas sensíveis ao fogo (HOFFMANN, 1998) teve a frequência reduzida até 1992, aumentou em 1993, diminuiu em 1994, e aumentou em 2012, na Área 1. Estes resultados sugerem que o fogo, possivelmente, influenciou a produção de sementes e a mortalidade de plântulas e indivíduos jovens desta espécie, pois na Área 1 a frequência foi sempre maior até 1994. A maior frequência em 1993, provavelmente, foi consequência do estímulo da reprodução vegetativa por meio de rebrotas, característico de M. guianensis (HOFFMANN, 1998), e também observada no estrato arbóreo-arbustivo (Capítulo 3).

Por outro lado, a espécie Echinolaena inflexa, da mesma forma que no trabalho de Rosa (1990), também no Distrito Federal, pode ter sido indiferente ao fogo, pois não teve variação na frequência entre a Área 1, com queimadas bienais, e a Área 2, de 1989 a 1994. Apresentou as maiores percentagens de frequência relativa nas duas áreas, em todo período de estudo, mas após a primeira queimada de 1988 teve redução na sua frequência. $E$. inflexa parece ter uma grande habilidade de colonização e competição, é uma espécie $\mathrm{C}_{3}$, e por possuir rizomas pode ser favorecida tanto em ambientes protegidos, quanto em locais com queimadas frequentes (MIRANDA; KLINK, 1996a,b).

Cabe enfatizar que Leite et al. (1997) observaram que E. inflexa apresenta grande sobrevivência de perfilhos na estação seca, independente do tipo de solo e da frequência de queima a que foi submetida. Em Campo sujo, no Distrito Federal, os dois tipos de crescimento de E. inflexa, recrutamento de plântulas por sementes e por rebrotas, promoveram saldo positivo na área com fogo, e, na área controle, os recrutamentos faziam parte da manutenção da espécie dentro da comunidade (MIRANDA; KLINK, 1996b).

O período sem fogo por 18 anos, nas duas áreas, também influenciou a frequência das espécies em 2012. A proteção das duas áreas com diferentes históricos favoreceu algumas espécies e excluiu outras, e, consequentemente, proporcionou diferenças na composição florística e na frequência das espécies em cada área. $\mathrm{Na}$ área com queimadas bienais (Área 1) foi observado o maior número de espécies com uma ocorrência e espécies com diferentes histórias de vida quanto à capacidade de recuperação após o distúrbio. Após queimadas frequentes, algumas espécies podem necessitar de muito tempo para se 
recuperar e florescer novamente (WHELAN, 2002), e sendo assim, muitas podem ser favorecidas com a exclusão do fogo. Myrsine guianensis, por exemplo, que é uma espécie considerada sensível ao fogo (HOFFMANN, 1998), aumentou a frequência nas duas áreas, possivelmente, devido ao estímulo tanto da reprodução sexuada quanto da vegetativa.

As espécies invasoras podem ser utilizadas como parâmetro de avaliação dos níveis de intervenção humana nos ecossistemas do Cerrado (FILGUEIRAS, 2002). Assim, em 2012, a espécie invasora Schizachyrium condensatum foi encontrada nas duas áreas e Cassytha filiformis na Área 1. Já, na Área 2 foi observada a presença do capim-gordura (Melinis minutiflora), uma espécie exótica (MENDONÇA et al., 2008), que tem invadido as formações mais abertas do Cerrado e é considerada uma ameaça para a diversidade (HOFFMANN, 2004; SATO et al., 2013), sugerindo que houve intervenção humana, principalmente, nesta área.

Assim, os resultados indicam que as diferenças encontradas entre as duas áreas podem estar relacionadas aos efeitos da fragmentação, que podem variar com o histórico, tamanho e forma do fragmento, impactos das ações humanas, grau de isolamento e, também, com a sensibilidade da comunidade e dos indivíduos de cada espécie a estes processos (SCARIOT et al., 2003). Uma vez que os fragmentos menores estão mais sujeitos aos diversos efeitos decorrentes da fragmentação, nas áreas estudadas, com diferentes históricos de fogo, o pisoteio de gado bovino, a invasão de gramíneas (CARMO et al., 2011) e a pressão antrópica do entorno (SCARIOT et al., 2003), especialmente após 1994, com a construção de condomínios e assentamentos rurais, podem também ter influenciado as respostas da comunidade e das espécies nas duas áreas da Reserva da Embrapa Cerrados em 2012. 


\subsection{CONCLUSÕES}

As queimadas bienais não modificaram a riqueza de espécies e a diversidade, mas alteraram a estrutura da comunidade.

As duas áreas, após 18 anos de exclusão do fogo, não mostraram alterações na riqueza, mas na diversidade e na estrutura da comunidade.

A exclusão do fogo por 18 anos não favoreceu a similaridade florística entre as duas áreas.

Os resultados anuais não mostraram diferenças na riqueza de espécies do estrato herbáceo durante o período de 1988 a 1994, com queimadas bienais, e em 2012, com 18 anos de exclusão do fogo, podendo ser um indicativo da recuperação um ano após as queimadas e da resiliência da comunidade diante do distúrbio. 


\section{REFERÊNCIAS BIBLIOGRÁFICAS}

ABDALA, G.C.; CALDAS, L.S.; HARIDASAN, M.; EITEN, G. Above and belowground organic matter and root: shoot ratio in a cerrado in Central Brazil. Brazilian Journal of Ecology, v.2, n.1, p.11-23, 1998.

ALMEIDA, R.F.; FAGG, C.W.; OLIVEIRA, M.C.; MUNHOZ, C.B.R.; LIMA, A.S.; OLIVEIRA, L.S.B. Mudanças florísticas e estruturais no cerrado sensu stricto ao longo de 27 anos (1985-2012) na Fazenda Água Limpa, Brasília, DF. Rodriguésia, v.65, n.1, p.1$19,2014$.

ALVES, L.F.; VIEIRA, S.A.; SCARANELLO, M.A.; CAMARGO, P.B.; SANTOS, F.A.M.; JOLY, C.A.; MARTINELLI, L.A. Forest structure and live aboveground biomass variation along an elevational gradient of tropical Atlantic moist forest (Brazil). Forest Ecology and Management, v.260, p.679-691, 2010.

AMARAL, A.G. Mudanças estruturais e florísticas do estrato herbáceo-arbustivo em campo sujo e campo limpo úmido na Fazenda Água Limpa-DF após sete anos. 2008. Dissertação (Mestrado) - Departamento de Botânica. Universidade de Brasília, Brasília, 2008.

AMARAL, A.G.; MUNHOZ, C.B.R.; EUGÊNIO, C.U.O.; FELFILI, J.M. Vascular flora in dry-shrub and wet grassland Cerrado seven years after a fire, Federal District, Brazil. Check List , v.9, n.3, p.487-503, 2013.

ANDRADE, L.A.Z.; FELFILI, M.J.; VIOLATTI, L. Fitossociologia de uma área de cerrado denso na RECOR-IBGE, Brasília-DF. Acta Botanica Brasilica, v.16, n.2, p.225$240,2002$.

ANDRADE, L.A.Z.; MIRANDA, H. S. O fator fogo no banco de sementes. In: MIRANDA, H.S. Org. Efeitos do fogo sobre a estrutura de comunidades de Cerrado: resultados do Projeto Fogo. Brasília: IBAMA, 2010. p.103-119.

APPEZZATO-DA-GLÓRIA, B; CURY, G.; SOARES, M.K.M.; ROCHA, R.; HAYASHI, A.H.H. Underground systems of Asteraceae species from the Brazilian Cerrado. Journal of the Torrey Botanical Society, v.135, n.1, p.103-113, 2008.

AQUINO, F.G. Dinâmica da vegetação lenhosa em fragmentos de cerrado sentido restrito em Gerais de Balsas, Maranhão. 2004. 88f. Tese (Doutorado em Ecologia) Universidade de Brasília, Brasília, 2004.

AQUINO, F.G.; VILELA, M.F.; CAMARGO, W.R.F., CAMARGO, A.J.A.; OLIVEIRAFILHO, E.C.; PASSOS, F.B., SOUSA, S.R. Uso e cobertura do solo, caracterização biótica e de qualidade da água como subsídio para elaboração do plano de manejo da área da Embrapa Cerrados. Boletim de pesquisa e desenvolvimento, v.248. Planaltina, DF: Embrapa Cerrados, 2009.

AQUINO, F.G.; WALTER, B.M.T.; RIBEIRO, J.F. Dinâmica de populações de espécies lenhosas de Cerrado, Balsas, Maranhão. Revista Árvore, v.31, n.5, p.793-803, 2007a. 
AQUINO, F.G.; WALTER, B.M.T.; RIBEIRO, J.F. Woody community dynamics in two fragments of "cerrado" stricto sensu over a seven-year period (1995-2002), MA, Brazil. Revista Brasileira de Botânica, v.30, p.113-121, 2007b.

ARAUJO, M.M.; CHAMI, L.; LONGHI, S.J.; AVILA, A.L.; BRENA, D.A. Análise de agrupamento em remanescente de floresta ombrófila mista. Ciência Florestal, v.20, n.1, p.1-18, 2010.

ASSUNÇÃO, S.; FELFILI, J.M. Fitossociologia de um fragmento de cerrado sensu stricto na APA do Paranoá, DF. Brasil. Acta Botânica Brasilica, v.18, p. 903-909, 2004.

BALDUÍNO, A.P.C.; SOUZA, A.L.; MEIRA NETO, J.A.A.; SILVA, A.F.; SILVAJÚNIOR, M.C. Fitossociologia e análise comparativa da composição florística do Cerrado da flora de Paraopeba-MG. Revista Árvore, v.29, p.25-34, 2005.

BARBOSA, A.A.A. Biologia reprodutiva de comunidade de campo sujo, Uberlândia, MG. 1997. 180f. Tese (Doutorado em Ecologia) - Universidade Estadual de Campinas, Instituto de Biologia, Campinas, SP, 1997.

BARBOSA, R.I.; FEARNSIDE, P.M. Above-ground biomass and the fate of carbon after burning in the savannas of Roraima, Brazilian Amazonia. Forest Ecology and Management, v.216, p.295-316, 2005.

BARBOSA-FILHO, W.G.; ARAUJO, A.C. Fenologia de floração e síndromes de polinização na serra de Maracaju, Mato Grosso do Sul. In: Encontro de Iniciação Científica, ENIC, 10;. 2009. Anais..., 2009. 19p. Disponível em: $<$ http://www.propp.ufms.br/gestor/titan.php?target=openFile\&fileId=655> Acesso em: 2015.

BATALHA, M.A.; ARAGAKI, S.; MANTOVANI, W. Variações fenológicas das espécies do cerrado em Emas (Pirassununga, SP). Acta Botanica Brasilica, v.11, p.61-78, 1997.

BATALHA, M.A.; MANTOVANI, W. Reproductive phenological patterns of cerrado plant species at the Pé-de-Gigante Reserve (Santa Rita do Passa Quatro, SP, Brazil): a comparison between the herbaceous and woody floras. Revista Brasileira de Biologia, v.60, n.1, p.129-145, 2000.

BATALHA, M.A.; MANTOVANI, W. Floristic composition of the cerrado in the pé-degigante reserve (Santa Rita do Passa Quatro, Southeastern Brazil). Acta botanica brasílica, v.15, n.3, p.289-304, 2001.

BATALHA, M.A.; MARTINS, F.R. The Vascular Flora of the Cerrado in Emas National Park (Central Brazil): a Savanna Flora Summarized. Brazilian Archives of Biology and Technology, v.50, n.2, p.269-277, 2007.

BAWA, K.S. Plant-pollinator interactions in tropical rain forests. Annual review of ecology system, v.21, p.399-422, 1990.

BOND, W.J.; MIDGLEY, J.J. Ecology of sprouting in woody plants: the persistence niche. Trends in Ecology and Evolution, v.16, n.1, p.45-51, 2001. 
BRAGA, A.R.S.; SPERA, S.T.; CORRÊIA, J.R.; SOUSA-SILVA, J.C. Fire action on the chemical characteristics of a Dark Red Latosol (Oxisol) in the Cerrado strito sensu, Brazilian Savannas. In: Congrés Mondiale de Science du Sol, 16., 1998, Montpellier, França. Actes/Proceedings. Montpellier, France: ISSS-AISS-IBG-SIGS, 1998.

BRAGA, E.P. Relação entre parâmetros de radiação solar e espécies herbáceosubarbustivas de cerrado sentido restrito no Jardim Botânico de Brasília. 2010. 62 f. Dissertação (Mestrado em Ecologia) - Universidade de Brasília, Instituto de Ciências Biológicas, Brasília, 2010.

BRASIL. Ministério do Meio Ambiente. Mapeamento do uso e cobertura do Cerrado: Projeto TerraClass Cerrado 2013. Brasília: MMA, 2015. 67p.

BRAZ, V.B.; KANEGAE, M.F.; FRANCO, A.C. Estabelecimento e desenvolvimento de Dalbergia miscolobium Benth. em duas fitofisionomias típicas dos cerrados do Brasil central. Acta Botanica Brasilica, v.14, n.1, p.27-35, 2000.

BUSSAB, W. de O.; MIAZAKI, E. S.; ANDRADE, D.F. Introdução à análise de agrupamentos. São Paulo: USP-IME, 1990. 211p. (Trabalho apresentado no $9^{\circ}$ Simpósio Nacional de Probabilidade e Estatística, São Paulo, 1990).

BUSTAMANTE, M.M.C.; OLIVEIRA, E.L. Impacto das atividades agrícolas, florestais e pecuárias nos recursos naturais. In: FALEIRO, F.G., AND A.L. FARIAS NETO (Eds.). Savanas: desafios e estratégias para o equilíbrio entre sociedade, agronegócio e recursos naturais. Planaltina: EMBRAPA Cerrados, 2008. p. 646-669.

CANFIELD, R.H. Application of the line interception method in sampling range vegetation.Journal of Forestry, v.39, p.388-394, 1941.

CARDOSO, E.L.; CRISPIM, S.M.A.; RODRIGUES, C.A.G.; BARONI JR., W. Biomassa aérea e produção primária do estrato herbáceo em campo de Elyonurus muticus submetido à queima anual, no Pantanal. Pesquisa Agropecuária Brasileira, v.35, p.2309-2316, 2000a.

CARDOSO, E.L.; CRISPIM, S.M.A.; RODRIGUES, C.A.G.; BARONI JR., W. Composição e dinâmica da biomassa aérea após a queima em savana gramíneo-lenhosa no Pantanal. Pesquisa Agropecuária Brasileira, v.35, n.11, p.2309-2316, 2000 b.

CARMO, A.B.; VASCONCELOS, H.L.; ARAÚJO, G.M. Estrutura da comunidade de plantas lenhosas em fragmentos de cerrado: relação com o tamanho do fragmento e seu nível de perturbação. Revista Brasileira de Botânica, v.34, n.1, p.31-38, 2011.

CARMO, F.F. Padrões de diversidade, composição florística e estrutura de comunidades de plantas em afloramentos rochosos, Quadrilátero Ferrífero, Brasil. 2014. 160f. Tese (Doutorado em Ecologia) - Universidade Federal de Minas Gerais, Belo Horizonte, 2014. 
CARVALHO, A.P.F. Estudo de características foliares de espécies de lenhosas de cerrado e sua relação com os espectros de reflectância. 2005. 142f. Tese (Doutorado em Ecologia) - Universidade de Brasília, Brasília, 2005.

CARVALHO, F.A.; FELFILI, J.M. Variações temporais na comunidade arbórea de uma floresta decidual sobre afloramentos calcários no Brasil Central: composição, estrutura e diversidade florística. Acta Botanica Brasilica, v.25, n.1, p.203-214, 2011.

CARVALHO, F.A.; RODRIGUES, V.H.P.; KILCA, R.V.; SIQUEIRA, A.S.; ARAÚJO, G.M.; SCHIAVINI, I. Composição florística, riqueza e diversidade de um cerrado sensu stricto no sudeste do estado de Goiás. Bioscience Journal, v. 24, n. 4, p. 64-72, Oct./Dec. 2008 .

CASTRO, E.A.; KAUFFMAN, J. B. Ecosystem structure in the Brazilian Cerrado: a vegetation gradient of aboveground biomass, root mass and consumption. Journal of Tropical Ecology, v.14, p.263-283, 1998.

CASTRO-NEVES, B.M. Efeito de queimadas em áreas de cerrado stricto sensu e na biomassa de raízes finas. 2007. 82f. Tese (Doutorado em Ecologia) - Universidade de Brasília, Brasília, 2007.

CAVALCANTE, T.R.M.; NAVES, R.V.; FRANCESCHINELLI, E.V.; SILVA, R.P. Polinização e formação de frutos em araticum. Bragantia, Campinas, v.68, n.1, p.13-21, 2009.

CHAO, A. Estimating the population size for capturerecapture data with unequal catchability. Biometrics, v.43, p.783-791, 1987.

CHASE, M.W.; REVEAL, J.L. A phylogenetic classification of the land plants to accompany APG III. Botanical Journal of the Linnean Society, v.161, 122-127, 2009.

CHAVES, A.D.C.G.; SANTOS, R.M.S.; SANTOS, J.O.; FERNANDES, A.A.; MARACAJÁ, P.B. A importância dos levantamentos florístico e fitossociológico para a conservação e preservação das florestas. Agropecuária científica no semiários, v. 9, n. 2 , p. 42-48, 2013.

CIANCIARUSO, M.V.; SILVA, I.A.; BATALHA, M.A. Diversidades filogenética e funcional: novas abordagens para a ecologia de comunidades. Biota Neotropica, v.9, n.3, p.93-193, 2009.

CIANCIARUSO, M.V.; SILVA, I.A.; BATALHA, M.A. Aboveground biomass of functional groups in the ground layer of savannas under different fire frequencies. Australian Journal of Botany, v.58, n.3, p.169-174, 2010.

CIANCIARUSO, M.V; SILVA, I.A.; BATALHA, M.A.; GASTON, K.J.; PETCHEY, O.L. The influence of fire on phylogenetic and functional structure of woody savannas: moving from species to individuals. Perspectives in Plant Ecology, Evolution and Systematics, v.14, p.205-216, 2012. 
CIRNE, P.; MIRANDA, H.S. Effects of prescribed fires on the survival and release of seeds of Kielmeyera coriacea (Spr.) Mart. (Clusiaceae) in savannas of Central Brazil. Brazilian Journal of Plant Physiology, Londrina, v. 20, n.3, p.197-204, 2008.

CLARKE, P.J.; LAWES, M.J.; MIDGLEY, J.J.; LAMONT, B.B.; OJEDA, F.; BURROWS, G.E.; ENRIGHT, N.J.; KNOX, K.J.E. Resprouting as a key functional trait: how buds, protection and resources drive persistence after fire. New Phytologist, v.197, p.19-35, 2013.

COLWELL, R.K. EstimateS: Statistical estimation of species richness and shared species from samples. 2006. Version 8. Persistent URL <purl.oclc.org/estimates>.

COLWELL, R.K.; CODDINGTON, J.A. Estimating terrestrial biodiversity through extrapolation. Philosophical Transactions of the Royal Society, Series B, v.345, p.101118, 1994.

CORÁ, J.E.; FERNANDES, C.; BERALDO, J.M.G.; MARCELO, A.V. Adição de areia para dispersão de solos na análise granulométrica. Revista Brasileira da Ciência do Solo, v.33, p.255-262, 2009.

CORNELISSEN, J.H.C.; LAVOREL, S.; GARNIER, E., DÍAZ, S.; BUCHMANN, N.; GURVICH, D.E.; REICH, P.B.; STEEGE, H.TER.; MORGAN, H.D.; VAN DER HEIJDEN, M.G.A.; PAUSAS, J.G.; POORTER, H. A handbook of protocols for standardised and easy measurement of plant functional traits worldwide. Australian Jounal of Botany, v.51, p.335-380, 2003.

COUTINHO, L.M. Contribuição ao conhecimento do papel ecológico das queimadas na floração de espécies do Cerrado. 1976. Tese de Livre Docência, Universidade de São Paulo, São Paulo, 1976.

COUTINHO, L.M. Ecological effects of fire in Brazilian Cerrado. In: HUNTLEY, B.J.; WALKER, B.H. (eds.). Ecology of tropical Savanas. Berlin: Springer-Verlag, 1982. p.273-291.

COUTINHO, L.M. Fire in the ecology of the Brazilian Cerrado. In: GOLDAMMER, J. G. (Ed.). Fire in the Tropical Biota: ecosystem processes and global challenges. Berlin: Springer-Verlag, 1990. p.82-105. (Ecological Studies, v. 8).

COUTINHO, L.M.; VUONO, Y.S. de; LOUSA, J.S. Aspecto ecológicos do fogo no cerrado. IV. A época da queimada e a produtividade primaria liquida epigeia do estrato herbáceo subarbustivo. Revista Brasileira de Botânica, São Paulo, v.5, n.1/2, p.37-41, 1982.

COUTINHO, L.M.; VUONO, Y.S. de; LOUSA, J.S. Aspecto ecológicos do fogo no cerrado. IV. A época da queimada e a produtividade primaria liquida epigeia do estrato herbáceo subarbustivo. Revista Brasileira de Botânica, São Paulo, v.5, n.1/2, p.37-41, 1982. 
DELITTI, W.B.C.; PAUSAS, J.G.; BURGER, D.M. Belowground biomass seasonal variation in two Neotropical savannahs (Brazilian Cerrados) with different fire histories. Annals of Forest Science, v.58, p.713-721, 2001.

DENG A.F.; ZANG, A.R.; CHEN, B. Identification of functional groups in an old-growth tropical montane rain forest on Hainan Island, China. Forest Ecology and Management, v. 255, n.5-6, p.1820-1830, 2008.

DIAS NETO, O.C.; LOPES, S.F.; OLIVEIRA, A.P.; VALE, V.S.; GUSSON, A.E.; SCHIAVINI, I. Estrutura de duas espécies vegetais de Cerrado em área queimada e não queimada, Caldas Novas, GO. In: Simpósio Nacional Cerrado, 9.; Simpósio Internacional Savanas Tropicais, 2., Brasília, 2008. Desafios e Estratégias para o equilíbrio entre sociedade, agronegócio e recursos naturais. Brasília, 2008.

DODAGENA, G.K. CAMPOS, D.V.B.; CALDERANO, S.B.; TEIXEIRA, W.G.; VIANA, J.H.M. (Orgs.) Manual de métodos de análise de solos. Rio de Janeiro: Embrapa Solos, 2011.

EMBRAPA - Empresa Brasileira de Pesquisa Agropecuária. Centro Nacional de Pesquisa de Solos. Manual de métodos de análises de solos. 2.ed. rev. Rio de Janeiro: EMBRAPA, 1997. 255p.

ENCINAS, J.I.; SILVA, G.F.; PINTO, J.R.R. Idade e crescimento das árvores. Brasília: UnB, 2005. 40p. v.7. (Comunicações Técnicas Florestais).

EUGÊNIO, C.U.O.; MUNHOZ, C.B.; FELFILI, J.M. Dinâmica temporal do estrato herbáceo-arbustivo de uma área de campo limpo úmido em Alto Paraíso de Goiás, Brasil. Acta Botanica Brasilica, v.25, n.2, p.497-507, 2011.

FELFILI, J.M; FELFILI, M. C. Diversidade alfa e beta no cerrado sensu stricto da Chapada Pratinha, Brasil. Acta Botânica Brasílica, São Paulo, v.15, n.1, p.243-254, 2001.

FELFILI, J.M.; REZENDE, R.P. Conceitos e métodos em fitossociologia. Brasília: Universidade de Brasília, 2003. (Comunicações técnicas, v.5, n.1).

FELFILI, J.M.; SILVA JÚNIOR, M.C. A comparative study of cerrado (sensu stricto) vegetation in Central Brasil. Journal of Tropical Ecology, v.9, p. 277-289, 1993.

FELFILI, J.M.; SILVA JÚNIOR, M.C. Biogeografia do bioma cerrado: estudo fitofisionômico na chapada do espigão mestre do São Francisco. Brasília: Editora Universidade de Brasília, 2001. 152p. p.74-79.

FELFILI, J.M.; REZENDE, A.V.; SILVA JÚNIOR, M.C.; SILVA, M.A. Changes in the floristic composition of cerrado sensu stricto in Brazil over a nine-year period. Journal of Tropical Ecology, v.16, p.579-590, 2000.

FELFILI, J. M.; SILVA-JÚNIOR, M. C.; SEVILHA, A. C.; FAGG, C. W.; WALTER, B. M. T.; NOGUEIRA, P. E.; REZENDE, A. V. Diversity, floristic and structural patterns of cerrado vegetation in Central Brazil. Plant Ecology, v. 175, p. 37-46, 2004. 
FELFILI, J.M.; CARVALHO, F.A.; HAIDAR, R.F. (eds.). Manual para o monitoramento de parcelas permanentes nos biomas Cerrado e Pantanal. Brasília: Universidade de Brasília, 2005. 51p.

FELFILI, M.J.; FELFILI, M.C.; NOGUEIRA, P.E.; ARMAS, J.F.S.; FARINAS, M.R.; NUNES, M.; SILVA JR., M.C.; REZENDE, A.V.; FAGG, C.W. Padrões fitogeográficos e sua relação com sistemas de terra no Bioma Cerrado. In: SANO, S.M.; ALMEIDA, S.P.; RIBEIRO, J.F. Cerrado: ecologia e flora. Brasília: Embrapa Informação Tecnológica, 2008. p.213-228.

FELFILI, J.M.; CARVALHO, F.A.; LIBANO, A.M.; VENTUROLI, F.; PEREIRA, B.A.S.; MACHADO, L.M. Análise multivariada: princípios e métodos em estudos de vegetação. In: FELFILI, J.M.; EISENLOHR, P.V.; MELO, M.M.R.F.; ANDRADE, L.A.; MEIRA NETO, J.A.A. Fitossociologia no Brasil: métodos e estudos de casos. Viçosa: UFV, 2011. p.122-155.

FIDELIS, A.; PIVELLO, V.R. Deve-se Usar o Fogo como Instrumento de Manejo no Cerrado e Campos Sulinos? Biodiversidade Brasileira, Ano I, n.2, p.12-25, 2011.

FIEDLER, N.C.; AZEVEDO, I.N.C.; REZENDE, A.V.; MEDEIROS, M.B.; VENTUROILI, F. Efeito de Incêndios Florestais na Estrutura e Composição Florística de uma Área de Cerrado Sensu Stricto na Fazenda Água Limpa-DF. Revista Árvore, v.28, n.1, p.129-138, 2004.

FILGUEIRAS, T.S. Herbaceous plant communities. In: OLIVEIRA, P. S.; MARQUIS, J.R. (Org.). The Cerrados of Brazil: ecology and natural history of a neotropical savanna. New York: Columbia University Press, 2002. p.121-139.

FILGUEIRAS, T.S.; FELFILI, J.M.; SILVA JR., M.C.; NOGUEIRA, P.E. Floristic and structural comparison of cerrado (sensu stricto) vegetation in central Brazil. In: DALLMEIER, F.; COMISKEY, J.A. (eds.). Forest biodiversity in North, Central and South America, and the Caribbean: research and monitoring, Paris: The Parthenon Publishing Group, 1998. p.633-647.

FLORA DO BRASIL. Lista de Espécies da Flora do Brasil. Rio de janeiro, Jardim Botânico do Rio de Janeiro. Disponível em: http://reflora.jbrj.gov.br/jabot/listaBrasil/ConsultaPublicaUC/ConsultaPublicaUC.do

Acesso em: dez./2015.

FONSECA, M.S.; SILVA JR., M.C. Fitossociologia e similaridade florística entre trechos de Cerrado sentido restrito em interflúvio e em vale no Jardim Botânico de Brasília, DF. Acta Botanica Brasilica, v.18, n.1, p.19-29, 2004.

FREITAS, W.K.; MAGALHÃES, L.M.S. Métodos e parâmetros para estudo da vegetação com ênfase no estrato arbóreo. Floresta e Ambiente, v.19, n.4, p.520-540, 2012.

GARDNER, T.A. Tree-grass coexistence in the Brazilian cerrado: demographic consequences of environmental instability. Journal of Biogeography, v.33, p.448-463, 2006. 
GOLDSTEIN, G.; MEINZER, F.C.; BUCCI, S.J.; SCHOLZ, F., G.; FRANCO, A.C.; HOFFMANN, W.A. Water economy of Neotropical savanna trees: six paradigms revisited. Tree Physiology, v.28, p.395-404, 2008.

GOTTSBERGER, G. Beetle pollination and flowering rhythm of Annona spp. (Annonaceae) in Brazil. P1ant Systematics and Evolution, v.167, p.165-187, 1989.

GUEDES, D. M. Resistência das árvores do Cerrado ao fogo: papel da casca como isolante térmico. 1993.113 f. Dissertação (Mestrado em Ecologia) - Universidade de Brasília, Brasília, 1993.

GUZMÁN, G.G.; MORALES, E. Life-history strategies of plant pathogens: distribution patterns and phylogenetic analysis. Ecology, v.88, n.3, p.589-596, 2007.

HAMMER, O.; HARPE, A.T.D.; RYAN, P.D. PAST: Paleontological statistics software package for education and data analysis. Paleontologia Eletronica, v.4, n.1, p. 1-9, 2001.

HENRIQUES, R.P.B. Análise fitossociológica em vegetação de Cerrado sensu stricto em um gradiente topográfico no Brasil Central. Boletim do Herbário Ezechias Paulo Heringer, v.13-61, p.61-84, 2004.

HENRIQUES, R.P.B. Influência da história, solo e fogo na distribuição e dinâmica das fitofisionomias no bioma Cerrado. In: SCARIOT, A.; SOUSA-SILVA, J.C.; FELFILI, J.M. (Org.). Cerrado: ecologia, biodiversidade e conservação. Brasília: MMA, 2005. p.7392.

HENRIQUES, R.P.B.; HAY, J.D. Patterns and dynamics of plant population. In: OLIVEIRA, P.S.; MARQUIS, R.J. The Cerrados of Brazil: ecology and natural history of a neotropical savanna. New York: Columbia University Press, 2002. p.140-158.

HERINGER, I.; JACQUES, A.V.A. Adaptação das plantas ao fogo: enfoque na transição floresta - campo. Ciência Rural, Santa Maria, v.31, n.6, p.1085-1090, 2001.

HOFFMANN, W. A. Post-burn reproduction of woody plants in a Neotropical savanna: the relative importance of sexual and vegetative reproduction. Journal of Applied Ecology, v.35, p.422-433, 1998.

HOFFMANN, W.; ADAMSE, R.; HARIDASAN, M.; CARVALHO, M. T. DE; GEIGER, E. L.; PEREIRA, M. A. B.; GOTSCH, S. G.; FRANCO, A. C. Tree topkill, not mortality, governs the dynamics of savanna-forest boundaries under frequent fire in central Brazil. Ecology, v.90, p.1326-1337, 2009.

HOFFMANN, W.A. Fire and population dynamics of woody plants in a neotropical savanna: matrix model projections.Ecology, v.80, n.4, , p.1354-1369, 1999.

HOFFMANN, W.A. The effects of fire and cover on seedling establishment in a Neotropical Savanna. Journal of Ecology, v.84, n.3, p.383-393, 1996.

HOFFMANN, W.A.; JACKSON, R.B. Vegetation-climate feedbacks in the conversion of tropical savanna to grassland. Journal of Climate, v.13, p.1593-1602, 2000. 
HOFFMANN, W.A.; LUCATELLI, V.M.P.C; SILVA, F.J.; AZEUEDO, I.N.C.; MARINHO, M.S.; ALBUQUERQUE, A.M.S.; LOPES, A.O.; MOREIRA, S.P. Impact of the invasive alien grass Melinis minutiflora at the savanna-forest ecotone in the Brazilian Cerrado. Diversity and Distributions, v.10, p.99-103, 2004.

HOFFMANN, W.A.; MOREIRA, A.G. The role of fire in population dynamics of woody plants. In: OLIVEIRA, P.S.; MARQUIS, R.J. The Cerrados of Brazil: ecology and natural history of a Neotropical Savanna. New York: Columbia University Press, 2002. p.159-177.

HOFFMANN, W.A.; SOLBRIG, O.T. The role of topkill in the differential response of savanna woody species to fire. Forest Ecology and Mangement, v.180, p.273-286, 2003.

KENT, M.; COKER, P. Vegetation description and analysis. London: Belhaven Press, 1992. 373p.

KLINK, C.A.; MACHADO, R.B. A conservação do Cerrado brasileiro. Megadiversidade, v.1, n.1, p.147-155, 2005.

KLINK, C.A.; SOLBRIG, O.T. Efeito do fogo na biodiversidade de plantas do Cerrado. In: SARMIENTO, G.; CABIDO, M.(ed.). Biodiversidad y Funcionamento de Pastizales y Sabanas en América Latina. Venezuela: CYTED y CIELAT, 1996. pp.231-244.

KORNING, J.; BALSLEV, H. Growth and mortality of trees in Amazonian tropical rain forest in Ecuador. Journal of Vegetation Science, v.4, p.77-86, 1994.

KUHLMANN, M. Frutos e sementes atrativos para a fauna: guia de campo. Brasília: Rede de Sementes, 2012. 360p.

LEINSTER, T.; COBBOLD, C.A. Measuring diversity: the importance of species similarity. Ecology, v.93, n.3, p.477-489, 2012.

LENZA, E.; KLINK, C.A. Comportamento fenológico de espécies lenhosas em um cerrado sentido restrito de Brasília, DF. Revista Brasileira de Botânica, v.29, n.4, p.627638, 2006.

LIBANO, A.M.; FELFILI, J.M. Mudanças temporais na composição florística e na diversidade de um cerrado sensu stricto do Brasil Central em um período de 18 anos (1985-2003). Acta Botânica Brasílica, v.20, n.4, p. 927-936, 2006.

LILIENFEIN, J.; WILCKE, W.; ZIMMERMANN, R.; GERSTBERGER, P.; ARAÚJO, G.M.; ZECH, W. Nutrient storage in soil and biomass of native Brazilian Cerrado. Journal of Plant Nutrition Soil Science, v.164, 487-495, 2001.

LIMA, A.S. Caracterização florística e estrutural e avaliação da chuva de sementes em área de cerrado sentido restrito em Brasília, DF: subsídios para conservação e recuperação. 2015. 99f. Tese (Doutorado em Botânica) - Universidade de Brasília, Departamento de Botânica, Brasília, 2015. 
LIMA, E.S.; LIMA, H.S.; RATTER, J.A. Mudanças pós-fogo na estrutura e composição da vegetação lenhosa em um cerrado mesotrófico, no período de cinco anos (1997-2002) em Nova Xavantina - MT. Cerne, Lavras, v. 15, n. 4, p. 468-480, 2009.

LINDENMAYER, D.B.; LIKENS, G.E.; ANDERSEN, A.; BOWMAN, D.; BULL, C.M.; BURNS, E.; DICKMAN, C.R.; HOFFMANN, A.A.; KEITH, D.A.; LIDDELL, M.J.; LOWE, A.J.; METCALFE, D.J.; PHINN, S.R.; JEREMY RUSSELL-SMITH, J.; NIKKI THURGATE, N.; WARDLE, G.M. Value of long-term ecological studies. Austral Ecology, v.37, p.745-757, 2012.

LOIOLA, P.P.L; CIANCIARUSO, M.V.; SILVA, I.A.; BATALHA, M.A. Functional diversity of herbaceous species under different fire frequencies in Brazilian savannas. Flora, v.205, p.674-681, 2010.

LOIOLA, P.P.L; SCHERER-LORENZEN, M.; BATALHA, M.A. The role of environmental filters and functional traits in predicting the root biomass and productivity in savannas and tropical seasonal forests. Forest Ecology and Management, v.342, p.49$55,2015$.

LOPES, S.F.; VALE, V.S.; SCHIAVINI, I. Efeito de queimadas sobre a estrutura e composição da comunidade vegetal lenhosa do Cerrado sentido restrito em Caldas Novas, Go. Revista Árvore, v.33, n.4, p.695-704, 2009.

LORENZI, H.; BACHER, L.; LACERDA, M.; SARTORI, S. Frutas brasileiras e exóticas cultivadas (de consumo in natura). São Paulo: Plantarum, 2006. 640p.

MCCUNE, B.; MEFFORD, M.J. PC Ord 5.0. Multivariate analysis of ecological data. MjM software. Gleneden Beach, Ore, 2006.

MAGURRAM, A.E. Ecological diversity and its measurements. New Jersey: Princeton University, 1988.

MANTOVANI, W.; MARTINS, F.R. Florística do cerrado na reserva biológica de Moji Guaçu, SP. Acta Botanica Brasilica, v.7, p.33-60, 1993.

MARIMON JÚNIOR, B.H.; HARIDASAN, M. Comparação da vegetação arbórea e características edáficas de um cerradão e um Cerrado sensu stricto em áreas adjacentes sobre solo distrófico no leste de Mato Grosso, Brasil. Acta Botanica Brasilica, v.19, n.4, p.913-926, 2005.

MARQUES, A.J.; SANTIL, F.L.P.; CUNHA, J.E. O uso do clinômetro no levantamento topográfico. Estudo de caso: levantamento pedológico. Boletim de Geografia, v.18, p.135-141, 2000.

MARQUIS, R.J.; DINIZ, I.; MORAIS, H.C. Patterns and correlates of interspecic variation in foliar insect herbivory and pathogen attack in Brazilian cerrado. Journal of Tropical Ecology, v.17, p.127-148, 2001. 
MARTINS, F.Q.; BATALHA, M.A. Vertical and Horizontal Distribution of Pollination Systems in Cerrado Fragments of Central Brazil. Brazilian archives of biology and technology, v.50, n.3, p.503-514, 2007.

MAZZONI-VIVEIROS, S.C.; COSTA, C.G. Periderme. In: APPEZZATO-DA GLÓRIA, B.; CARMELlO-GUERREIRO, S.M. (eds.). Anatomia Vegetal. Viçosa: UFV, 2003. p.237-263.

MEDEIROS, M.B. Efeitos do fogo nos padrões de rebrotamento em plantas lenhosas, em campo sujo, após queimadas prescritas. 2002. 112f. Tese (Doutorado em Ecologia) Universidade de Brasília, Brasília, 2002.

MEDEIROS, M.B.; FIEDLER, N.C. Incêndios florestais no Parque Nacional da Serra da Canastra: desafios para a conservação da biodiversidade. Ciência Florestal, v.14, p.157168, 2004.

MEDEIROS, M.B.; FIEDLER, N.C. Heterogeneidade de ecossistemas, modelos de desequilíbrio e distúrbios. Biodiversidade Brasileira, Ano I, n.2, p.4-11, 2011.

MEDEIROS, M.B.; MIRANDA, H.S. Mortalidade pós-fogo em espécies lenhosas de campo sujo submetido a três queimadas prescritas anuais. Acta Botânica Brasilica, São Paulo, v.19, n.3, p.493-500, 2005.

MEDEIROS, M.B.; MIRANDA, H.S. Post-fire resprouting and mortality in cerrado woody plant species over a three-year period. Edinburgh Journal of Botany, v.65, n.1, p.53-68, 2008.

MEDEIROS, M.M.; FELFILI, J.M.; LIBANO, A.M. Comparação florístico-estrutural dos estratos de regeneração e adulto em cerrado sensu stricto no Brasil Central. Cerne, Lavras, v.13, n.3, p.291-298, 2007.

MEDINA, E.; SILVA, J.F. Savannas of northern South América: a steady state regulated by water-fire interactions on a background of low nutrient availability. Journal of Biogeography, v.17, p.403-413, 1990.

MEIRELLES, M.L.; OLIVEIRA, R.C.; RIBEIRO, J.F.; VIVALDI, L.J.; RODRIGUES, L.A.; SILVA, G.P. Utilização do método de interceptação na linha em levantamento quantitativo do estrato herbáceo do Cerrado. Boletim do Herbário Ezechias Pauloo Heringer, Brasília, v.9, p.60-68, 2002.

MENDONCA, R.C.; FELFILI, J.M; FAGG, C.W; SILVA, M.A.; FILGUEIRAS, T.S; WALTER, B.M.T. Análise florística da Chapada do Espigão Mestre de São Francisco. In: FELFILI, J.M.; SILVA JÚNIOR, M.C. Biogeografia do bioma cerrado: estudo fitofisionômico na Chapada do Espigão Mestre do São Francisco. Brasília: Editora Universidade de Brasília, 2001. 152p. p.74-79.

MENDONÇA, R.C.; FELFILI, J.M.; WALTER, B.M.T.; SILVA JÚNIOR, M.C.; REZENDE, A.V.; FILGUEIRAS, T.S.; NOGUEIRA, P.E.; FAGG, C.W. Flora Vascular do Cerrado. In: SANO, S.M.; ALMEIDA, S.P. (eds). Cerrado: ambiente e flora. Brasília: EMBRAPA-CPAC, 2008. p.289-556. 
MEWS, H.A.; MARIMON, B.S.; MARACAHIPES, L.; FRANCZAK, D.D.; MARIMONJUNIOR, B.H. Dinâmica da comunidade lenhosa de um Cerrado Típico na região Nordeste do Estado de Mato Grosso, Brasil. Biota Neotropica, v.11, n.1, p.73-82, 2011 a.

MEWS, H.A.; MARIMON, B.S.; PINTO, J.R.R.; SILVÉRIO, D.V. Dinâmica estrutural da comunidade lenhosa em Floresta Estacional Semidecidual na transição Cerrado-Floresta Amazônica, Mato Grosso, Brasil. Acta Botanica Brasilica, v.25, n.4, p.845-857, 2011 b.

MEWS, H.A; SILVÉRIO, D.V.; LENZA, E.; MARIMON, B.S. Influência de agrupamentos de bambu na dinâmica pós-fogo da vegetação lenhosa de um cerrado típico, Mato Grosso, Brasil. Rodriguésia, v.64, n.2, p.211-221, 2013.

MILBERG, P.; LAMONT, B.B.; PEREZ-FERNANDEZ, M.A. Survival and growth of native and exotic composites in response to a nutrient gradient. Plant Ecology, v.1451, p.125-132, 1999.

MIRANDA, A.C.; MIRANDA, H.S.; DIAS, I.O.; DIAS, B.F. Soil and air temperatures during prescribed Cerrado fires in central Brazil. Journal of Tropical Ecology, v.9, p.313-320, 1993.

MIRANDA, H.S.; SATO, M.N. Efeitos do fogo na vegetação lenhosa do Cerrado. In: SCARIOT, A.; SOUZA-SILVA, J. C.; FELFILI, J. M. (Org.). Cerrado: ecologia, biodiversidade e conservação. Brasília: MMA, 2005. p. 95-103.

MIRANDA, H.S.; ROCHA E SILVA, E.P.; MIRANDA, A.C. Comportamento do Fogo em Queimadas de Campo Sujo. In: MIRANDA, H. S.; DIAS, B. F. S.; SAITO, C. H. (eds.) Impacto de queimadas em área de cerrado e restinga. Brasília: UnB, 1996. p.1-10.

MIRANDA, H.S.; BUSTAMANTE, M.M.C.; MIRANDA, A.C. The fire factor. In: OLIVEIRA, P.S.; MARQUIS, R.J. (Eds.). Cerrados of Brazil. New York: Columbia University Press, 2002. p. 51-68.

MIRANDA, H.S.; SATO, M.N.; ANDRADE, S.M.A.; HARIDASAN, M.; MORAIS, H.C. Queimadas de Cerrado: caracterização e impactos. In: AGUIAR, L.M.S., CAMARGO, A.J.A. (Eds.). Cerrado: ecologia e caracterização. Brasília: EMBRAPA Cerrados, 2004. p.69-123.

MIRANDA, H.S.; SATO, M.N.; NASCIMENTO NETO, W.; AIRES, F.S. Fires in the cerrado, Brazilian savanna. In: COCHRANE, M.A. Tropical Fire Ecology: Climate Change, Land Use, and Ecosystem Dynamics. New York: Springer, 2009. P.427-450.

MIRANDA, H.S.; NETO, W.N.; NEVES, B.M.C. Caracterização das queimadas no Cerrado. In: MIRANDA, H.S. (Org.). Efeitos do regime do fogo sobre a estrutura de comunidade de Cerrado: Projeto fogo. Brasília: IBAMA, 2010. p.23-33.

MIRANDA, M.I. Efeitos de diferentes regimes de queima sobre a comunidade de gramíneas do Cerrado. 2002. 104f. Tese (Doutorado em Ecologia) - Universidade de Brasília, Departamento de Ecologia, Brasília, 2002. 
MIRANDA, M.I.; KLINK, C.A. Influência do fogo na alocação de biomassa de Echinolaena inflexa em duas áreas de campo sujo de Cerrado. In: MIRANDA, H.S.; SAITO, C.H.; DIAS, B.F.S. (Org.). Impactos de queimadas em áreas de cerrado e restinga. Brasília: UnB, 1996a. p. 37-45.

MIRANDA, M.I.; KLINK, C.A. Colonização de campo sujo de Cerrado com diferentes regimes de queima pela gramínea Echinolaena inflexa (Poaceae). In: MIRANDA, H.S.; SAITO, C.H.; DIAS, B.F.S. (Org.). Impactos de queimadas em áreas de cerrado e restinga. Brasília: UnB, 1996b. p. 46-51.

MIRANDA, S.C. Variação espacial e temporal da biomassa vegetal em áreas de Cerrado. 2012. 143f. Tese (Doutorado em Ecologia) - Universidade de Brasília, Brasília, 2012.

MIRANDA, S.C.; BUSTAMANTE, M.; SILVA JÚNIOR, M.C. Variação multitemporal na biomassa aérea da vegetação lenhosa de cerrado sentido restrito. In: Congresso de Ecologia do Brasil, 10., 2011. Anais... São Lourenço: SEB, 2011.

MIRANDA, S.C.; SILVA JR., M.C.; CARVALHO, P.S. O efeito da proteção do fogo na estrutura da vegetação lenhosa de uma área de Cerrado sentido restrito no Brasil. Heringeriana, v.7, n.1, p.61-72, 2013.

MISTRY, J. Fire in the Cerrado (Savannas) of Brazil: an ecological review. Progress in Physical Geography, v.22, n.4, p.425-448, 1998.

MOHR, A.; LENZA, E. Síndromes de polinização de uma comunidade lenhosa em área de Cerrado Sentido Restrito, Ribeirão Cascalheira, Mato Grosso. Curso de campo, 2011. Disponível em: <http://www.unemat.br/prppg/ppgec/mestrado/docs/Producoes_Curso_de_Campo_2011/R elatorios_Individuais_2011/Adriana_Mohr_Sindromes_de_polinizacao_em_cerrado.pdf.> Acesso em: dezembro/2015.

MOREIRA, A.G. Fire protection and vegetation dynamics in the Brazilian Cerrado. 1992. 200f. Tese (Ph.D.) - Harvard University, Harvard, 1992.

MOREIRA, A.G. Proteção contra o fogo e seu efeito na distribuição e composição de espécies de cinco fisionomias de Cerrado. In: MIRANDA, H.S.; SATO, C.H.; DIAS, B.F.S. (org.). Impactos de queimadas em áreas de Cerrado e Restinga. Brasília: UnB, 1996. p.112-121.

MOREIRA, A.G. Effects of fire protection on savanna structure in Central Brazil. Journal of Biogeography, v.27, p.1021-1029, 2000.

MOREIRA, F.; CATRY, F.; DUARTE, I.; ACÁCIO, V.; SILVA, J.S. A conceptual model of sprouting responses in relation to fire damage: an example with cork oak (Quercus suber L.) trees in Southern Portugal. Plant Ecology, v.201, n.1, p.77-85, 2009.

MORO, M.F.; MARTINS, F.R. Métodos de levantamento do componente arbóreoarbustivo. In: FELFILI, J.M.; EISENLOHR, P.V.; MELO, M.M.R.F.; ANDRADE, L.A.; 
MEIRA NETO, J.A.A. Fitossociologia no Brasil: métodos e estudos de casos. Viçosa: UFV, 2011. p.174-212.

MUELLER-DOMBOIS, D.; ELLENBERG, H. Aims and methods of vegetation ecology. New York: Willey and Sons, 1974.

MULLER, S.C.; OVERBECK, G.E.; PFADENHAUER, J.; PILlAR, V.D. Plant functional types of woody species related to fire disturbance in forest-grassland ecotones. Plant Ecology, v.189, p.1-14, 2007.

MUNHOZ, C.B.R.; FELFILI, J.M. Fenologia do estrato herbáceo-subarbustivo de uma comunidade de campo sujo na Fazenda Água Limpa no Distrito Federal, Brasil. Acta Botanica Brasílica, v.19, n.4, p.979-988, 2005.

MUNHOZ, C.B.R.; AMARAL, A.G. Efeito do fogo no estrato herbáceo-subarbustivo do Cerrado. In: MIRANDA, H.S. (Org.). Efeitos do regime do fogo sobre a estrutura de comunidade de Cerrado: Projeto fogo. Brasília: IBAMA, 2010. p.93-102.

MUNHOZ, C.B.R.; ARAÚJO, G.M. Métodos do estrato herbáceo-subarbstivo. In: FELFILI, J.M.; EISENLOHR, P.V.; MELO, M.M.R.F.; ANDRADE, L.A.; MEIRA NETO, J.A.A. Fitossociologia no Brasil: métodos e estudos de casos. Viçosa: UFV, 2011. p.213-230.

MUNHOZ, C.B.R.; FELFILI, J.M. Fitossociologia do estrato herbáceo-subarbustivo de uma área de campo sujo no Distrito Federal, Brasil1. Acta Botanica Brasilica, v.20, n.3, p.671-685, 2006.

MUNHOZ, C.B.R.; FELFILI, J.M. Fitossociologia do estrato herbáceo-subarbustivo em campo limpo úmido no Brasil Central. Acta Botânica Brasilica, São Paulo, v.22, n.4, p.905-913, 2008.

NEFABAS, L.L.; GAMBIZA, J. Fire-tolerance mechanisms of common woody plant species in a semiarid savanna in south-western Zimbabwe. African Journal of Ecology, v.45, p.550-556, 2007.

OLIVEIRA FILHO, A.T.; CURI, N.; VILELA, E.A.; CARVALHO, D.A. Effects of canopy gaps, topography, and soils on the distribution of woody species in a Central Brazilian Deciduous Dry Forest. Biotropica, v.30, n.3, p.362-375, 1998.

OLIVEIRA, A.C. Flora e estrutura de remanescente de floresta estacional decidual em Presidente Juscelino, MG. 2012. 76f. Dissertação (Mestrado em Ciência Florestal) Universidade Federal dos Vales do Jequitinhonha e Mucuri, Diamantina, 2012.

OLIVEIRA, P.E.; GIBBS, P.E. Reproductive biology of woody plants in a cerrado community of the central Brazil. Flora, v.195, p.311-329, 2000.

ONIGEMO, A.E.; MIRANDA, H.S.; HARIDASAN, M. Efeitos de queimadas bienais e quadrienais sucessivas sobre a biomassa do estrato rasteiro de campo sujo de Cerrado. In: Congresso Nacional de Ecologia do Brasil, 6., 2003, Fortaleza. Resumos... Fortaleza, 2003. p.361-362. 
PARRON, L.M.; SILVA, J.C.S.; CAMARGO, A.J.A. de. Reservas ecológicas da Embrapa Cerrados: caracterização e zoneamento. Planaltina: EMBRAPA - CPAC, 1998. $80 \mathrm{p}$.

PASSOS, F.B. Avaliação de Solanum lycocarpum A. St.Hil. (Solanaceae) e de poleiros artificiais como facilitadores na restauração de área perturbada de Cerrado sentido restrito. 2009. 87f. Dissertação (Mestrado em Botânica) Universidade de Brasília, Brasília, 2009.

PAUSAS, J.G. Bark thickness and fire regime. Functional Ecology, v.29, n.3, p.315-327, 2015.

PERES, M.K. Diásporos do Cerrado atrativos para fauna: chave interativa, caracterização visual e relações ecológicas. 2011. 122f. Dissertação (Mestrado em Botânica) - Universidade de Brasília, Brasília, 2011.

PÉREZ-HARGUINDEGUY, N; S. DÍAZA, S.; GARNIER, E.; LAVOREL, S.; POORTER, H.; JAUREGUIBERRY, P.;. BRET-HARTE, M.S; CORNWELL, W.K.; CRAINE, J.M.; GURVICH, D.E.; URCELAY, C.; VENEKLAASH, E.J.; REICH, P.B.; POORTER, L.; WRIGHT, I.J.; RAY, P.; ENRICOA, L.; PAUSAS, J.G.; DE VOSF, A.C.; BUCHMANN, N.; FUNES, G.; QUÉTIER, F.; HODGSON, J.G.; THOMPSON, K.; MORGAN, H.D.; TER STEEGE, H.; VAN DER HEIJDEN, M.G.A.; SACKT, L.; BLONDER, B.; POSCHLOD, P.; VAIERETTI, M.V.; CONTI, G.; STAVER, A.C.; AQUINO, S.; CORNELISSEN, J.H.C. New handbook for standardised measurement of plant functional traits worldwide. Australian Journal of Botany, v.61, p.137-234, 2013.

PETCHEY, O.L.; GASTON, K.J. Functional diversity: back to basics and looking forward. Ecology Letters, v.9, n.6, p.741-758, 2006.

PIJL, L. van der. Principles of dispersal in higher plants. 3.ed. Nova Iorque: Springer Verlag, 1982.

PILON, N.A.L.; UDULUTSCH, R.G.; DURIGAN, G. Padrões fenológicos de 111 espécies de Cerrado em condições de cultivo. Hoehnea, v.42, n.3, p.425-443, 2015.

PINHEIRO, E.S.; DURIGAN, G. Dinâmica espaço-temporal (1962-2006) das fitofisionomias em unidade de conservação do Cerrado no sudeste do Brasil. Revista Brasileira de Botânica, v.32, n.3, p.441-454, 2009.

PIVELLO, V.; CARVALHO, V.; LOPES, P.; PECCININI, A.; ROSSO, S. Abundance and distribution of native and alien grasses in a Cerrado (Brazilian savanna) biological reserve. Biotropica, v.31, p.72-82, 1999.

PIVELLO, V.R.; OLIVERAS, I; MIRANDA, H.S.; HARIDASAN, M.; SATO, M.N.; MEIRELLES, S.T. Effect of fires on soil nutrient availability in an open savanna in Central Brazil. Plant and Soil, v.337, n.1-2, p.111-123, 2010. 
POLISEL, R.T. Florística e fitossociologia do estrato herbáceo e da regeneração arbórea de trecho de floresta secundária em Juquitiba, SP, Brasil. Ciência Florestal, v.21, n.2, p.229$240,2011$.

PRADO JÚNIOR, J.A.; LOPES, S.F.; VALE, V.S.; DIAS NETO, O.C.; SCHIAVINI, I. Comparação florística, estrutural e ecológica da vegetação arbórea das fitofisionomias de um remanescente urbano de cerrado. Bioscience Journal, v.28, n.3, p.456-471, 2012.

QUEIROGA, J.L. Estudos de bordas de fragmentos de Cerrado em áreas de agricultura do Maranhão. 2001. 84f. Dissertação (Mestrado) - Universidade Estadual de Londrina, Londrina, 2001.

RANGEL, T.F.; DINIZ-FILHO, J.A.F.; BINI, L.M. SAM: a comprehensive application for Spatial Analysis in Macroecology. Ecography, v.33, p.46-50, 2010.

RAUNKIÆR, C. The life forms of plants and statistical plant geography, being the collected papers of C. Raunkiær. Oxford: Oxford University Press, 1934.

REIS, S.M.; MOHR, A.; GOMES, L.; SILVA, A.C.S.; ABREU, M.F.; LENZA, E. Síndromes de polinização e dispersão de espécies lenhosas de um fragmento de cerrado sentido restrito na transição Cerrado - Floresta Amazônica. Heringeriana, v.6, n.2, p.28$41,2012$.

REYS, P.; GUTIERREZ DE CAMARGO, M.G.G.; GROMBONE-GUARATINI, M.T.; TEIXEIRA, A.P.; ASSIS, M.A.; MORELLATO, L.P.C. Estrutura e composição florística de um Cerrado sensu stricto e sua importância para propostas de restauração ecológica. Hoehnea, v.40, n.3, p.449-464, 2013.

REZENDE, A.V.; FELFILI, J.M. Avaliação do estoque de carbono do Cerrado sensu stricto do Brasil Central. Brasília: Universidade de Brasília, 2004. 27p. (Comunicações Florestais, v.6, n.2).

REZENDE, A.V.; VALE, A.T. do; SANQUETTA, C.R.; FIGUEIREDO FILHO, A.; FELFILI, J.M. Comparação de modelos matemáticos para estimativa do volume, biomassa e estoque de carbono da vegetação lenhosa de um cessado sensu stricto em Brasília, DF. Scientia Forestalis, n.71, p.65-76, 2006.

RIBEIRO, J.F.; WALTER, B.M.T. As principais fitofisionomias do Bioma Cerrado. In: SANO, S.M.; ALMEIDA, S.P. de; RIBEIRO, J.F. Cerrado: ecologia e flora. Brasília: Embrapa Informação Tecnológica, 2008. p.152-212.

RIBEIRO, M.N.; SANCHEZ, M.; PEDRONI, F.; PEIXOTO, K.S. Fogo e dinâmica da comunidade lenhosa em cerrado sentido restrito, Barra do Garças, Mato Grosso. Acta Botânica Brasilica, v.26, n.1, p.203-217, 2012.

RIBEIRO, S.C.; JACOVINE, L.A.G.; SOARES, C.P.B.; MARTINS, S.V.; SOUZA, A.L.; NARDELLI, A.M.B. Quantificação de biomassa e estimativa de estoque de carbono em uma floresta madura no município de viçosa, minas gerais. Revista Árvore, v.33, n.5, p.917-926, 2009. 
RIBEIRO, S.C.; FEHRMANN, L.; SOARES, C.P.B.; JACOVINE, L.A.G.; KLEINN, C.; GASPAR, R.O. Above- and belowground biomass in a Brazilian Cerrado. Forest Ecology and Management, v.262, p.491-499, 2011.

RODRIGUES; L.A.; CARVALHO, D.A.; OLIVEIRA FILHO, A.T.; BOTREL, R.T.; SILVA, E.A. Florística e estrutura da comunidade arbórea de um fragmento florestal em Luminárias, MG. Acta Botanica Brasílica, v.17, n.1, p.71-87, 2003.

ROITMAN, I.; FELFILI, J.M.; REZENDE, A.V. Tree dynamics of a fire-protected cerrado sensu stricto surrounded by forest plantations, over a 13-year period (1991-2004) in Bahia, Brazil. Plant Ecology, v.197, p.255-267, 2008.

ROSA, C. M. M. Recuperação pós-fogo do estrato rasteiro de campo sujo de Cerrado. 1990. 162f. Dissertação (Mestrado em Ecologia) - Universidade de Brasília, Departamento de Ecologia, Brasília, 1990.

ROSSATO, D.R. Grupos funcionais em plantas do cerrado sensu stricto: utilização de recursos hídricos, variabilidade e efeito filogenético em parâmetros estruturais e funcionais foliares. 2011. 137f. Tese (Doutorado em Ecologia) - Universidade de Brasília, Brasília, 2011.

SALAZAR, A.; GOLDSTEIN, G. Effects of fire on seedling diversity and plant reproduction (sexual vs. vegetative) in neotropical savannas differing in tree density. Biotropica, v.46, n.2, p.139-147, 2014.

SAMBUICHI, R.H.R. Efeitos de longo prazo do fogo periódico sobre a fitossociologia da camada lenhosa de um Cerrado em Brasília, DF. 1991. 129f. Dissertação (Mestrado em Ecologia) - Universidadede Brasília, Brasília, 1991.

SANSEVERO, J.B.B. Classificação de grupos funcionais e caracterização de trajetórias sucessionais na Floresta Atlântica. 2013. 179f. Tese (Doutorado em Botânica) - Instituto de Pesquisas Jardim Botânico do Rio de Janeiro/Escola Nacional de Botânica Tropical, Rio de Janeiro, 2013.

SANTOS, H.G.; JACOMINE, P.K.T.; ANJOS, L.H.C.; OLIVEIRA, V.A.; LUMBRERAS, J.F.; COELHO, M.R.; ALMEIDA, J.A.; CUNHA, T.J.F.; OLIVEIRA, J.B. Sistema brasileiro de classificação de solos. 3.ed. Brasília: Embrapa, 2013. 353p.

SARTORELLI, P.A.R.; SILVA, J.M.S.; GORESNTEIN, M.R.; GOMES, J.E.; ÁVILA, E.Q. Rebrota após fogo de espécies arbóreas de diferentes grupos fenológicos foliares em Cerrado stricto sensu. Revista Científica Eletrônica de Engenharia Florestal, ano 6, n.10, 2007.

SATO M.N.; MIRANDA, H.S.; AIRES, S.S.; AIRES, F.S. Alterações na fitossociologia do estrato rasteiro de uma área de campo sujo, invadida por Melinis minutiflora P. Beauv., submetida a corte anual. Biodiversidade Brasileira, v.3, n.2, p.137-148, 2013.

SATO, M.N. Mortalidade de plantas lenhosas do cerrado submetidas a diferentes regimes de queima. 1996. $46 \mathrm{f}$. Dissertação (Mestrado em Ecologia) - Departamento de Ecologia, Universidade de Brasília, Brasília, 1996. 
SATO, M.N. Efeito a longo prazo de queimadas prescritas na estrutura da comunidade de lenhosas da vegetação do Cerrado sensu stricto. 2003. 84f. Tese (Doutorado em Ecologia) - Departamento de Ecologia, Universidade de Brasília, Brasília, 2003.

SATO, M.N.; MIRANDA, H.S. Mortalidade de plantas lenhosas do Cerrado sensu stricto submetidas a diferentes regimes de queima. In: MIRANDA, H.S.; SAITO, C.H.; DIAS, B.F.S. (org.). Impactos de queimadas em áreas de Cerrado e Restinga. Brasília: UnB, 1996. p. 102-111.

SATO, M.N.; MIRANDA, H.S.; MAIA, J.M.F. O fogo e o estrato arbóreo do Cerrado: efeitos imediatos e de longo prazo. In: MIRANDA, H.S. (Org.). Efeitos do regime do fogo sobre a estrutura de comunidade de Cerrado: Projeto fogo. Brasília: IBAMA, 2010. p.77-91.

SCARIOT, A.; FREITAS, S.R.; MARIANO NETO, E.; NASCIMENTO, M.T.; OLIVEIRA, L.C.; SANAIOTTI, T.; SEVILHA, A.C.; VILLELA, D.M. Efeitos da fragmentação sobre os habitats. In: RAMBALDI, D.M; OLIVEIRA, D.A.S. (orgs.). Fragmentação de ecossistemas. Brasília: MMA, 2003. p.103-123.

SCHOLES, R.J.; ARCHER, S.R. Tree-grass interactions in savannas. Annual Review of Ecology and Systematics, v.28, p.517-544, 1997.

SCOLFORO, J.R.S.; MELLO, J.M. Inventário florestal. Lavras: UFLA, 2006. 561p.

SCOLFORO, J.R.S.; THIERSCH, C.R. Biometria florestal: medição, volumetria e gravimetria. Lavras: UFLA, 2004. 285p.

SHEIL, D.; BURSLEM, D.F.R.P.; ALDER, D. The interpretation and misinterpretation of mortality rate measures. Journal of Ecology, v.83, p.331-333, 1995.

SHEPHERD, G.J. Manual do usuário. FITOPAC 2.1.2.85 Campinas: UNICAMP, 2010.

SILVA JR., M.C. Árvores do Cerrado: guia de campo. Brasília: Rede de Sementes, 2005. 278p.

SILVA JR., M.C.; PEREIRA, B.A.S. + 100 árvores do Cerrado - Matas de Galeria: Guia de campo. Brasília: Rede de Sementes do Cerrado, 2009.

SILVA, C.I.; ARAÚJO, G.; OLIVEIRA, P.E.A.M. Distribuição vertical dos sistemas de polinização bióticos em áreas de cerrado sentido restrito no Triângulo Mineiro, MG, Brasil. Acta Botanica Brasilica, v.26, n.4, p.748-760, 2012.

SILVA, C.S.P.; SANTOS, M.L. Comportamento fenológico no evento pós-queima e biologia reprodutiva de Spiranthera odoratissima A. St.-Hil. (Rutaceae). Biotemas, v.21, n.1, p.29-39, 2008. 
SILVA, D.M. Ecologia do fogo e diversidade funcional em comunidades vegetais de cerrado no Parque Nacional das Emas. 2013. 87f. Tese (Doutorado em Ecologia e Recursos Hídricos) - Universidade Federal de São Carlos, São Carlos, 2013.

SILVA, D.M.; LOIOLA, P.P.; ROSATTI, N.B.; SILVA, I.A.; CIANCIARUSO, M.V.; BATALHA, M.A. Os efeitos dos regimes de fogo sobre a vegetação de Cerrado no Parque Nacional das Emas, GO: considerações para a conservação da diversidade. Biodiversidade Brasileira, Ano 1, n.2, p.26-39, 2011.

SILVA, G.T.; SATO, M.N.; MIRANDA, H.S. Mortalidade de plantas lenhosas em campo sujo de Cerrado submetido a queimadas prescritas. In: MIRANDA, H. S.; SAITO, C. H.; DIAS, B. F. S. (Org.). Impactos de queimadas em áreas de cerrado e restinga. Brasília: ECL/UnB, 1996a. p. 93-101.

SILVA, G.T.; SATO, M.N.; MIRANDA, H.S.; FURTADO, D.A. Mortalidade de plantas lenhosas em campo-sujo submetido a queimadas prescritas. In: Simpósio sobre o cerrado, 8.; International Symposium on Tropical Savanas, 1996. Anais... Brasília: EMBRAPA, 1996b. p.208-212.

SILVA, I.A.; BATALHA, M.A. Woody plant species co-occurrence in Brazilian savannas under different fire frequencies. Acta Oecologica, v.36, n.1, p.85-91, 2010.

SILVA, I.A.; CIANCIARUSO, M.V.; BATALHA, M.A. Dispersal modes and fruiting periods in hyperseasonal and seasonal savannas, central Brazil. Revista Brasileira de Botânica, v.32, n.1, p.155-163, 2009.

SILVA, J.F.; FARIÑAS, M.R.; FELFILI, J.M.; KLINK, C.A. Spatial heterogeneity, land use and conservation in the cerrado region of Brazil. Journal of Biogeography, v.33, p.536-548, 2006.

SILVA, J.M.C.; BATES, J.M. Biogeographic patterns and conservation in the South American Cerrado: a tropical savanna hotspot. BioScience, v.52, p.225-233, 2002.

SILVA, J.S. Padrões fenológicos no Distrito Federal: congruência entre dados de herbário e estudos em campo. 2014. 204f. Tese (Doutorado em Botânica) - Universidade de Brasília, Brasília, 2014.

SILVA, J.S.; FELFILI, J.M.. Floristic composition of a conservation area in the Federal District of Brazil. Brazilian Journal of Botany, v.35, n.4, p.385-395, 2012.

SILVA, M.A. Mudanças na composição florística e estrutura de um cerrado sensu stricto, em um período de 12 anos (1985- 1997), na Fazenda Água Limpa (FAL)-Brasília - DF. 1999. 62f. Dissertação (Mestrado em Ciências Florestais) - Universidade de Brasília, Brasília, 1999.

SILVA, M.A. Mudança temporal da flórula subarbustiva-herbácea em comunidades de campo sujo de cerrado submetidas a queimadas prescritas no Distrito Federal, Brasil. 2005. 84f. Dissertação (Mestrado em Ciências Florestais) - Universidade de Brasília, Departamento de Engenharia Florestal, Brasília, 2005. 
SILVA, M.A.; NOGUEIRA, P.E. Avaliação fitossociológica do estrato arbustivo-herbáceo em cerrado stricto sensu após incêndio acidental, no Distrito Federal, Brasil. Boletim do Herbário Ezechias Paulo Heringer, v.4, p.65-78, 1999.

SILVA, M.R.; ARAÚJO, G.M. Dinâmica da comunidade arbórea de uma floresta semidecidual em Uberlândia, MG, Brasil. Acta Botanica Brasilica, v.23, n.1, p.49-56, 2009.

SILVEIRA, P.; KOEHLER, H.S.; SANQUETTA, C.R.; ARCE, J.E. O estado da arte na estimativa de biomassa e carbono em formações florestais. Floresta, v.38, n.1, p.185-206, 2008.

SIQUEIRA, M.F.; DURIGAN, G. Modelagem da distribuição geográfica de espécies lenhosas de cerrado no Estado de São Paulo. Revista Brasileira de Botânica, v.30, p.233243, 2007.

SOBRAL, F.L.; CIANCIARUSO, M.V. Estrutura filogenética e funcional de assembléias: (re)montando a ecologia de comunidades em diferentes escalas espaciais. Bioscience Journal, v.28, n.4, p.617-631, 2012.

SOKAL, R.R.; ROHLF, F.J. Introduction to Biostatistics. 2a.ed. New York: DOVER PUBLICATIONS, 2009. 363p.

SOLORZANO, A.; PINTO, J.R.R.; FELFILI, J.M.; HAY, J.D.V. Perfil florístico e estrutural do componente lenhoso em seis áreas de cerradão ao longo do bioma Cerrado. Acta Botânica Brasilica, v.26, n.2, p.328-341, 2012.

SOUCHIE, F.F. Rebrota de indivíduos lenhosos em área de cerrado sentido restrito como resposta ao fogo. 2015. 57f. Dissertação (Mestrado em Ciências Florestais) Universidade de Brasília, Brasília, 2015.

SOUSA, D.M.G.; LOBATO, E. (Ed.). Cerrado: correção do solo e adubação. 2.ed. Planaltina, DF: Embrapa Cerrados, 2004. 416 p.

SOUZA, A.J.B. Estrutura e dinâmica da vegetação lenhosa de cerrado sensu stricto no período de 19 anos na Reserva Ecológica do IBGE, Distrito Federal. 2010. 66f. Dissertação (Mestrado em Ecologia) - Universidade de Brasília, Brasília, 2010.

SOUZA, P.B. SAPORETTI JUNIOR, A.W.; SOARES, M.P.; VIANA, R.H.O.; CAMARGOS, V.L.; MEIRA NETO, J.A.A. Florística de uma área de cerradão na Floresta Nacional de Paraopeba - Minas Gerais. Cerne, v.16, p.86-93, 2010.

SPERA, S.T.; REATTO, A.; CORREIA, J.R.; SILVA, J.C.S. 2000. Características físicas de um Latossolo Vermelho-Escuro, no Cerrado de Planaltina, DF, submetido à ação do fogo. Pesquisa Agropecuária Brasileira, v.35, n.9, p.1817-1824.

STEFANELLO, D.; FERNANDES-BULHÃO, C.; MARTINS, S.V. Síndromes de dispersão de sementes em três trechos de vegetação ciliar (nascente, meio e foz) ao longo do rio Pindaíba, MT. Revista Árvore, v.33, n.6, p.1051-1061, 2009. 
SWAINE, M.D.; LIEBERMAN, D.; PUTZ, F.E. Th e dynamics of tree populations in tropical forest: a review. Journal of Tropical Ecology, v.3, p.359-366, 1987.

TAKAHASHI, F.S.C. Atributos e tipos funcionais de espécies lenhosas no cerrado. 2010. 133f. Tese (Doutorado em Ecologia) - Universidade de Brasília, Brasília, 2010.

TER BRAAK, C.J.F.; SMILAUER, P. Canoco for Windows Version 4.5. Wageningen, Biometris - Plant research international, 2002.

TILMAN, D. Functional diversity. In: LEVIN, S.A. (ed.). Encyclopedia of Biodiversity. San Diego: Academic Press, 2001. p.109-120.

TÓTHMÉRÉSZ, B. Comparasion of different methods for diversity ordering. Journal of Vegetation Science, v.6, p.283-290, 1995.

TROPICOS.ORG. Tropicos.org. Missouri Botanical Garden. Disponível em: <http://www.tropicos.org/> Acesso em: outubro/2015.

VALE, A.T.; ELIAS, P.S. Nível de proteção térmica da casca de quatro espécies lenhosas e a relação da arquitetura da casca com a transferência de calor. Ciência Florestal, v.24, n.4, p.977-985, 2014.

VALE, A.T., FIEDLER, N.C., SILVA, G.F. Avaliação energética da biomassa do Cerrado em função do diâmetro das árvores. Ciência Florestal, v.12, p.115-126, 2002.

VALE, A.T.; CARDOSO, T.B.; PEREIRA; R.S.; MARTINS, I.S. Influência das propriedades da casca de Vochysia thyrsoidea na transferência de calor para o câmbio. Revista Científica Eletrônica de Engenharia Florestal, ano 8, n.13, 2009.

VALE, V.S. Padrões e processos ecológicos do componente arbóreo em uma área de floresta estacional semidecidual (Araguari, MG). 2008. 91f. Dissertação (Mestrado em Ecologia) - Universidade Federal de Uberlândia, Minas Gerais, 2008.

VALE, V.S.; DORNELES, M.C.; SCHIAVINI, I.; MENDONÇA, E.T.; ALMEIDA, C.G.; SILVA, P.A.; CRESPILHO, R.F. Grupos funcionais e sua importância ecológica na vegetação arbórea em um remanescente florestal urbano, Uberlândia, MG. Natureza on line, v.9, n.2, p.67-75, 2011.

VALE, V.S.; SCHIAVINI, I.; LOPES, S.F.; OLIVEIRA, A.P.; DIAS NETO, O.C.; GUSSON, A.E. Functional groups in a semideciduous seasonal forest in Southeastern Brazil. Biotemas, v.26, n.2, p. 45-58, 2013.

VALENTIN, J.L. Ecologia numérica: uma introdução à análise multivariada de dados ecológicos. Rio de Janeiro: Interciência, 2000. 117p.

VIEIRA, S.A.; ALVES, L.F.; AIDAR, M.P.M.; ARAÚJO, L.S.; BAKER, T.; BATISTA, J.L.F.; CAMPOS, M.C.R.; CAMARGO, P.B.; CHAVE, J.; DELITTI, W.B.; HIGUCHI, N.; HONÓRIO, E.; JOLY, C.A.; KELLER, M.; MARTINELLI, L.A.; MATTOS, E.A.; METZKER, T.; PHILLIPS, O.L.; SANTOS, F.A.M.; SHIMABUKURO, M.T.; 
SILVEIRA, M.; TRUMBORE, S.E. Estimation of biomass and carbon stocks: the case of the Atlantic Forest. Biota Neotropica, v.8, n.2, p.21-29, 2008.

WALTER, B.M.T.; RIBEIRO, J.F. Diversidade fitofisionômica e o papel do fogo no bioma Cerrado. In: MIRANDA, H.S. (Org.). Efeitos do regime do fogo sobre a estrutura de comunidade de Cerrado: Projeto fogo. Brasília: IBAMA, 2010. p.58-76.

WHELAN, R.J. The ecology of fire. Cambridge: Cambridge University Press, 2002. 346. (Cambridge studies in ecology).

ZAR, J. H. Biostatistical analysis. New Jersey: Prentice-Hall, 2009.

ZILLI, G.Z.; MARIMON, B.S.; CARVALHO, M.A.C.; SOBRAL, F.L.; MARIMONJUNIOR, B.H. Avaliação temporal das características funcionais de espécies arbóreas em fitofisionomias da transição Cerrado-Amazônia, Mato Grosso, Brasil. Biotemas, v.27, n.4, p. 51-61, 2014. 


\section{APÊNDICES}

Apêndice 1 - Número de indivíduos por família e espécie, em duas áreas (Área 1, Área 2), com diferentes históricos de fogo, no período de 1988 a 2012, em Cerrado sentido restrito, em Planaltina (DF), considerando também os indivíduos que tiveram mortalidade da parte aérea e rebrotaram. Onde: Área 1, com queimadas bienais de 1988 a 1992, e proteção do fogo de 1995 a 2012; Área 2, com proteção do fogo de 1988 a julho de 1994, e de 1995 a 2012. Obs.: em 1994, o levantamento dos dados foi feito antes do fogo acidental que atingiu as duas áreas em agosto.

\begin{tabular}{|c|c|c|c|c|c|c|c|c|c|c|c|c|c|c|}
\hline \multirow[t]{2}{*}{ FAMÍLIA - ESPÉCIE } & \multicolumn{7}{|c|}{ ÁREA 1} & \multicolumn{7}{|c|}{ ÁREA 2} \\
\hline & 1988 & 1990 & 1991 & 1992 & 1993 & 1994 & 2012 & 1988 & 1990 & 1991 & 1992 & 1993 & 1994 & 2012 \\
\hline \multicolumn{15}{|l|}{ Annonaceae } \\
\hline Annona crassiflora Mart. & 6 & 5 & 7 & 6 & 6 & 6 & 9 & & & & & & & 2 \\
\hline Annona monticola Mart. & & & 2 & 2 & 2 & 2 & 15 & & 8 & 3 & 1 & 4 & 4 & 9 \\
\hline Annona tomentosa R.E.Fr. & & & & & & & 50 & 1 & 1 & & & & & 35 \\
\hline \multicolumn{15}{|l|}{ Apocynaceae } \\
\hline Aspidosperma macrocarpum Mart. & 9 & 2 & 8 & 9 & 9 & 9 & 22 & 11 & 25 & 30 & 31 & 34 & 34 & 45 \\
\hline Aspidosperma tomentosum Mart. & 8 & 9 & 5 & 6 & 6 & 6 & 14 & 14 & 16 & 17 & 17 & 19 & 21 & 31 \\
\hline Hancornia speciosa Gomes & 2 & & 1 & 1 & 1 & 1 & 1 & & & & & & & \\
\hline \multicolumn{15}{|l|}{ Araliaceae } \\
\hline Schefflera macrocarpa (Cham. \& Schltdl.) Frodin & 17 & 12 & 14 & 14 & 14 & 14 & 27 & 4 & 4 & 3 & 3 & 3 & 3 & 22 \\
\hline \multicolumn{15}{|l|}{ Arecaceae } \\
\hline Butia leiospatha (Barb.Rodr.) Becc. & & & & & & & & 1 & 1 & 1 & 1 & 1 & & \\
\hline Syagrus flexuosa (Mart.) Becc. & 32 & 34 & 36 & 36 & 40 & 40 & 9 & 11 & 11 & 16 & 18 & 19 & 19 & 6 \\
\hline Syagrus oleracea (Mart.) Becc. & & & & & & & & & & 1 & 1 & 1 & 1 & \\
\hline \multicolumn{15}{|l|}{ Asteraceae } \\
\hline Eremanthus goyazensis (Gardner) Sch.Bip. & 14 & & & & & & 1 & 4 & 8 & 7 & 9 & 9 & 10 & 3 \\
\hline Piptocarpha rotundifolia (Less.) Baker & 6 & 6 & 6 & 6 & 6 & 8 & 11 & 10 & 9 & 9 & 9 & 9 & 9 & 13 \\
\hline \multicolumn{15}{|l|}{ Bignoniaceae } \\
\hline Handroanthus ochraceus (Cham.) Mattos & 19 & 13 & 13 & 15 & 15 & 15 & 12 & 13 & 16 & 17 & 19 & 22 & 22 & 6 \\
\hline Zeyheria montana Mart. & 4 & 2 & & & & & 3 & 4 & 5 & 5 & 5 & 5 & 5 & 4 \\
\hline \multicolumn{15}{|l|}{ Burseraceae } \\
\hline Protium ovatum Engl. & 8 & & & & & & 31 & 13 & 13 & 6 & 7 & 9 & 9 & 47 \\
\hline
\end{tabular}




\begin{tabular}{|c|c|c|c|c|c|c|c|c|c|c|c|c|c|c|}
\hline \multirow[t]{2}{*}{ FAMÍLIA - ESPÉCIE } & \multicolumn{7}{|c|}{ ÁREA 1} & \multicolumn{7}{|c|}{ ÁREA 2} \\
\hline & 1988 & 1990 & 1991 & 1992 & 1993 & 1994 & 2012 & 1988 & 1990 & 1991 & 1992 & 1993 & 1994 & 2012 \\
\hline \multicolumn{15}{|l|}{ Calophyllaceae } \\
\hline Kielmeyera coriacea Mart. \& Zucc. & 9 & 7 & 7 & 8 & 8 & 7 & 46 & 9 & 22 & 29 & 29 & 34 & 32 & 26 \\
\hline Kielmeyera speciosa A.St.-Hil. & & & & & & & 1 & & & & & & & \\
\hline \multicolumn{15}{|l|}{ Caryocaraceae } \\
\hline Caryocar brasiliense Cambess. & 8 & 6 & 9 & 9 & 9 & 9 & 22 & 4 & 5 & 5 & 5 & 5 & 5 & 10 \\
\hline \multicolumn{15}{|l|}{ Celastraceae } \\
\hline Plenckia populnea Reissek & 17 & 8 & 15 & 16 & 17 & 17 & 26 & 4 & 5 & 4 & 5 & 6 & 6 & 4 \\
\hline Salacia crassifolia (Mart. ex Schult.) G.Don & & 2 & & & & & & & & & & 1 & 1 & 2 \\
\hline \multicolumn{15}{|l|}{ Combretaceae } \\
\hline Terminalia fagifolia Mart. & & & & & & & 2 & & & & & & & \\
\hline \multicolumn{15}{|l|}{ Connaraceae } \\
\hline Connarus suberosus var. fulvus (Planch.) Forero & 18 & 12 & 12 & 12 & 12 & 12 & 25 & 14 & 20 & 22 & 23 & 23 & 21 & 11 \\
\hline \multicolumn{15}{|l|}{ Dilleniaceae } \\
\hline Davilla elliptica A.St.-Hil. & & & & & & & & & 1 & & & & & \\
\hline \multicolumn{15}{|l|}{ Ebenaceae } \\
\hline Diospyros hispida A.DC. & & 1 & & & & & 4 & 1 & 3 & 3 & 3 & 4 & 5 & 3 \\
\hline \multicolumn{15}{|l|}{ Erythroxylaceae } \\
\hline Erythroxylum campestre A.St.-Hil. & 12 & 6 & 2 & 2 & 1 & 1 & & 1 & & & & & & \\
\hline Erythroxylum deciduum A.St.-Hil. & 1 & 4 & 6 & 6 & 6 & 6 & 24 & & 5 & 8 & 8 & 8 & 9 & 20 \\
\hline Erythroxylum suberosum A.St.-Hil. & & & 7 & 7 & 7 & 7 & 5 & & 10 & 16 & 16 & 17 & 17 & 8 \\
\hline Erythroxylum tortuosum Mart. & 2 & 1 & & & & & 1 & 9 & 5 & & & & & \\
\hline \multicolumn{15}{|l|}{ Euphorbiaceae } \\
\hline Maprounea guianensis Aubl. & & & & & & & 10 & & & & & & & 1 \\
\hline \multicolumn{15}{|l|}{ Fabaceae } \\
\hline Andira humilis Mart. ex Benth. & 1 & & & & & & & 1 & 2 & 2 & 2 & 2 & 2 & \\
\hline Andira vermífuga (Mart.) Benth. & & & & & & & & & & & & & & 1 \\
\hline Bauhinia dumosa Benth. & & & & & & & 18 & & 15 & & & & & 26 \\
\hline Bauhinia rufa (Bong.) Steud. & & & & & & & 3 & & & & & & & 2 \\
\hline
\end{tabular}




\begin{tabular}{|c|c|c|c|c|c|c|c|c|c|c|c|c|c|c|}
\hline \multirow[t]{2}{*}{ FAMÍLIA - ESPÉCIE } & \multicolumn{7}{|c|}{ ÁREA 1} & \multicolumn{7}{|c|}{ ÁREA 2} \\
\hline & 1988 & 1990 & 1991 & 1992 & 1993 & 1994 & 2012 & 1988 & 1990 & 1991 & 1992 & 1993 & 1994 & 2012 \\
\hline Dalbergia miscolobium Benth. & 28 & 18 & 19 & 20 & 20 & 17 & 24 & 51 & 70 & 76 & 79 & 83 & 85 & 78 \\
\hline Dimorphandra mollis Benth. & 6 & 5 & 11 & 11 & 9 & 9 & 8 & 9 & 13 & 17 & 15 & 16 & 17 & 10 \\
\hline Enterolobium gummiferum (Mart.) J.F.Macbr. & & & & & & & 3 & & & & & & & 1 \\
\hline Hymenaea stigonocarpa Mart. ex Hayne & 6 & 6 & 6 & 7 & 7 & 7 & 8 & 10 & 11 & 13 & 13 & 13 & 13 & 13 \\
\hline Leptolobium dasycarpum Vogel & 9 & 8 & 9 & 9 & 9 & 9 & 25 & 8 & 19 & 19 & 19 & 21 & 23 & 27 \\
\hline Machaerium acutifolium Vogel & & & & & & & 4 & & & & & & & \\
\hline Machaerium opacum Vogel & 19 & 13 & 9 & 13 & 13 & 13 & 33 & 1 & 5 & 4 & 4 & 4 & 4 & 8 \\
\hline Mimosa claussenii Benth. & 6 & 5 & 6 & 6 & 4 & 3 & 5 & 7 & 7 & 2 & 3 & 3 & 3 & 15 \\
\hline Plathymenia reticulata Benth. & 3 & 2 & 4 & 4 & 4 & 3 & 2 & 1 & 1 & 1 & 1 & 1 & 1 & \\
\hline Senna rugosa (G.Don) H.S.Irwin \& Barneby & 1 & & & & & & 1 & & 3 & & & & & \\
\hline Stryphnodendron adstringens & 6 & 5 & 9 & 9 & 9 & 8 & 27 & 7 & 7 & 7 & 7 & 7 & 7 & 12 \\
\hline Tachigali subvelutina (Benth.) Oliveira-Filho & 22 & 15 & 19 & 22 & 22 & 22 & 25 & 4 & 5 & 5 & 5 & 6 & 6 & 7 \\
\hline \multicolumn{15}{|l|}{ Lamiaceae } \\
\hline Aegiphila verticillata Vell. & 11 & 10 & 14 & 17 & 17 & 18 & & 19 & 24 & 25 & 24 & 25 & 26 & \\
\hline \multicolumn{15}{|l|}{ Lauraceae } \\
\hline NI & & & & & & & & & & & & & & 1 \\
\hline \multicolumn{15}{|l|}{ Loganiaceae } \\
\hline Strychnos pseudoquina A.St.-Hil. & 8 & 7 & 7 & 6 & 6 & 6 & 11 & 4 & 4 & 6 & 7 & 7 & 7 & 8 \\
\hline \multicolumn{15}{|l|}{ Malpighiaceae } \\
\hline Byrsonima basiloba A.Juss. & & & & & & & 3 & & 1 & & & & & \\
\hline Byrsonima coccolobifolia Kunth & 1 & 2 & 2 & 2 & 2 & 2 & 10 & 1 & 1 & 2 & 3 & 4 & 4 & 9 \\
\hline Byrsonima verbascifolia (L.) DC. & 10 & 17 & 16 & 16 & 17 & 18 & 7 & 16 & 21 & 21 & 22 & 23 & 23 & 8 \\
\hline Heteropteris byrsonimifolia A.Juss. & & & & & & & 12 & & & & & & & 3 \\
\hline \multicolumn{15}{|l|}{ Malvaceae } \\
\hline $\begin{array}{l}\text { Eriotheca pubescens (Mart. \& Zucc.) Schott \& } \\
\text { Endl. } \\
\text { Melastomataceae }\end{array}$ & 2 & 1 & 3 & 3 & 3 & 3 & 8 & 2 & 3 & 3 & 3 & 3 & 3 & 3 \\
\hline Miconia albicans (Sw.) Triana & 8 & & & & & & 17 & & & & & & & 43 \\
\hline
\end{tabular}




\begin{tabular}{|c|c|c|c|c|c|c|c|c|c|c|c|c|c|c|}
\hline \multirow[t]{2}{*}{ FAMÍLIA - ESPÉCIE } & \multicolumn{7}{|c|}{ ÁREA 1} & \multicolumn{7}{|c|}{ ÁREA 2} \\
\hline & 1988 & 1990 & 1991 & 1992 & 1993 & 1994 & 2012 & 1988 & 1990 & 1991 & 1992 & 1993 & 1994 & 2012 \\
\hline Miconia burchellii Triana & & & & & & & 25 & & & & & & & 18 \\
\hline Miconia fallax DC. & & 3 & 2 & 2 & 2 & 2 & 5 & & & & & & & 30 \\
\hline Miconia ferruginata DC. & & & & & & & & & & & & & & 1 \\
\hline \multicolumn{15}{|l|}{ Moraceae } \\
\hline Brosimum gaudichaudii Trécul & 2 & 1 & 1 & 1 & 1 & 1 & 4 & 1 & 1 & & & & & 1 \\
\hline \multicolumn{15}{|l|}{ Myrtaceae } \\
\hline Psidium laruotteanum Cambess. & 10 & 3 & 5 & 6 & 6 & 5 & 15 & 8 & 8 & 8 & 8 & 9 & 9 & 5 \\
\hline \multicolumn{15}{|l|}{ Nyctaginaceae } \\
\hline Guapira graciliflora (Mart. ex Schmidt) Lundell & 75 & 4 & 5 & 13 & 9 & 9 & 180 & 34 & 43 & 33 & 31 & 36 & 37 & 56 \\
\hline Guapira noxia (Netto) Lundell & 16 & 16 & 18 & 16 & 10 & 11 & 17 & 28 & 39 & 41 & 42 & 45 & 45 & 27 \\
\hline Neea theifera Oerst. & & & 3 & 4 & 4 & 4 & 27 & & 25 & 33 & 35 & 38 & 39 & 2 \\
\hline \multicolumn{15}{|l|}{ Ochnaceae } \\
\hline Ouratea hexasperma (A.St.-Hil.) Baill. & 33 & 31 & 35 & 37 & 36 & 36 & 39 & 28 & 36 & 31 & 30 & 31 & 31 & 27 \\
\hline \multicolumn{15}{|l|}{ Primulaceae } \\
\hline Cybianthus gardneri (A.DC.) G.Agostini & & & & & & & 3 & & & & & & & 1 \\
\hline Myrsine guianensis (Aubl.) Kuntze & 37 & 4 & 9 & 14 & 13 & 13 & 158 & 70 & 121 & 131 & 143 & 169 & 175 & 348 \\
\hline \multicolumn{15}{|l|}{ Proteaceae } \\
\hline Roupala montana Aubl. & 21 & 5 & 5 & 7 & 5 & 5 & 57 & 10 & 16 & 20 & 20 & 23 & 23 & 35 \\
\hline \multicolumn{15}{|l|}{ Rubiaceae } \\
\hline Chomelia ribesioides Benth. ex A.Gray & 4 & & & & & & 5 & 1 & 7 & 6 & 3 & 8 & 8 & 2 \\
\hline Cordiera sessilis (Vell.) Kuntze & 9 & & & & & & 20 & & & & & & & 1 \\
\hline Palicourea rígida Kunth & 4 & 3 & 2 & 2 & 2 & 1 & 24 & 7 & 8 & 13 & 13 & 21 & 21 & 29 \\
\hline Tocoyena formosa (Cham. \& Schltdl.) K.Schum. & 5 & 2 & 5 & 5 & 5 & 6 & 2 & 2 & 2 & 1 & & 2 & 3 & 1 \\
\hline \multicolumn{15}{|l|}{ Rutaceae } \\
\hline Esenbeckia pumila Pohl & & & & & & & 4 & & & & & & & \\
\hline \multicolumn{15}{|l|}{ Salicaceae } \\
\hline Casearia sylvestris $\mathrm{Sw}$. & 5 & 1 & 1 & 1 & 1 & 1 & 1 & 1 & 4 & 4 & 4 & 5 & 4 & 1 \\
\hline
\end{tabular}




\begin{tabular}{|c|c|c|c|c|c|c|c|c|c|c|c|c|c|c|}
\hline \multirow[t]{2}{*}{ FAMÍLIA - ESPÉCIE } & \multicolumn{7}{|c|}{ ÁREA 1} & \multicolumn{7}{|c|}{ ÁREA 2} \\
\hline & 1988 & 1990 & 1991 & 1992 & 1993 & 1994 & 2012 & 1988 & 1990 & 1991 & 1992 & 1993 & 1994 & 2012 \\
\hline \multicolumn{15}{|l|}{ Sapotaceae } \\
\hline Pouteria ramiflora (Mart.) Radlk. & 7 & 5 & 5 & 5 & 5 & 5 & 8 & 3 & 3 & 3 & 3 & 3 & 3 & 2 \\
\hline \multicolumn{15}{|l|}{ Styracaceae } \\
\hline Styrax ferrugineus Nees \& Mart. & 54 & 26 & 31 & 40 & 40 & 38 & 43 & 27 & 42 & 40 & 42 & 47 & 47 & 24 \\
\hline \multicolumn{15}{|l|}{ Symplocaceae } \\
\hline Symplocos rhamnifolia A.DC. & 2 & 2 & 2 & 2 & 2 & 2 & & & & & & & & \\
\hline \multicolumn{15}{|l|}{ Velloziaceae } \\
\hline Vellozia squamata Pohl & 13 & 15 & 15 & 15 & 15 & 15 & 2 & 15 & 18 & 16 & 16 & 16 & 16 & 3 \\
\hline \multicolumn{15}{|l|}{ Vochysiaceae } \\
\hline Qualea grandiflora Mart. & & & & & & & & & & & & & & 1 \\
\hline Qualea multiflora Mart. & 2 & 2 & 2 & 3 & 3 & 3 & & & & & & & & \\
\hline Qualea parviflora Mart. & & & & & & & 8 & & & & & & & \\
\hline Salvertia convallariodora A.St.-Hil. & & & & & & & & 1 & 1 & 1 & 1 & 1 & 1 & 2 \\
\hline Vochysia elliptica Mart. & 15 & 13 & 13 & 14 & 13 & 13 & 13 & 4 & 4 & 4 & 4 & 5 & 5 & 6 \\
\hline Vochysia thyrsoidea Pohl. & 3 & 3 & 3 & 3 & 3 & 3 & 3 & & & & & & & \\
\hline Total & 656 & 383 & 446 & 490 & 476 & 471 & 1288 & 509 & 783 & 790 & 812 & 910 & 924 & 1206 \\
\hline
\end{tabular}


Apêndice 2 - Número de espécies (S) e de indivíduos (N) por família, em duas áreas (Área 1, Área 2), com diferentes históricos de fogo, em um Cerrado sentido restrito em Planaltina (DF), no período de 1988 a 2012. Onde: Área 1= com queimadas bienais de 1988 a 1992 , e proteção do fogo de 1995 a 2012; Área 2 = protegida contra o fogo de 1988 a julho de 1994, e de 1995 a 2012. Obs.: foram incluídos os indivíduos com mortalidade da parte aérea e rebrota; o levantamento dos dados, em 1994, ocorreu antes do fogo acidental que atingiu as duas áreas em agosto.

FAMÍLIA

ÁREA 1

ÁREA 2

\begin{tabular}{|c|c|c|c|c|c|c|c|c|c|c|c|c|c|c|c|c|c|c|c|c|c|c|c|c|c|c|c|c|}
\hline & \multicolumn{2}{|c|}{1988} & \multicolumn{2}{|c|}{1990} & \multicolumn{2}{|c|}{1991} & \multicolumn{2}{|c|}{1992} & \multicolumn{2}{|c|}{1993} & \multicolumn{2}{|c|}{1994} & \multicolumn{2}{|c|}{2012} & \multicolumn{2}{|c|}{1988} & \multicolumn{2}{|c|}{1990} & \multicolumn{2}{|c|}{1991} & \multicolumn{2}{|c|}{1992} & \multicolumn{2}{|c|}{1993} & \multicolumn{2}{|c|}{1994} & \multicolumn{2}{|c|}{2012} \\
\hline & $\mathrm{S}$ & $\mathrm{N}$ & $\mathrm{S}$ & $\mathrm{N}$ & $\mathrm{S}$ & $\mathrm{N}$ & $\mathrm{S}$ & $\mathrm{N}$ & $S$ & $\mathrm{~N}$ & $\mathrm{~S}$ & $\mathrm{~N}$ & $S$ & $\mathrm{~N}$ & $S$ & $\mathrm{~N}$ & $S$ & $\mathrm{~N}$ & $\mathrm{~S}$ & $\mathrm{~N}$ & $S$ & $\mathrm{~N}$ & $S$ & $\mathrm{~N}$ & $S$ & $\mathrm{~N}$ & $S$ & $\mathrm{~N}$ \\
\hline Annonaceae & 1 & 6 & 1 & 5 & 2 & 9 & 2 & 8 & 2 & 8 & 2 & 8 & 3 & 74 & 1 & 1 & 2 & 9 & 1 & 3 & 1 & 1 & 1 & 4 & 1 & 4 & 3 & 46 \\
\hline Apocynaceae & 3 & 19 & 2 & 11 & 3 & 14 & 3 & 16 & 3 & 16 & 3 & 16 & 3 & 37 & 2 & 25 & 2 & 41 & 2 & 47 & 2 & 48 & 2 & 53 & 2 & 55 & 2 & 76 \\
\hline Araliaceae & 1 & 17 & 1 & 12 & 1 & 14 & 1 & 14 & 1 & 14 & 1 & 14 & 1 & 27 & 1 & 4 & 1 & 4 & 1 & 3 & 1 & 3 & 1 & 3 & 1 & 3 & 1 & 22 \\
\hline Arecaceae & 1 & 32 & 1 & 34 & 1 & 36 & 1 & 36 & 1 & 40 & 1 & 40 & 1 & 9 & 2 & 12 & 2 & 12 & 3 & 18 & 3 & 20 & 3 & 21 & 2 & 20 & 1 & 6 \\
\hline Asteraceae & 2 & 20 & 1 & 6 & 1 & 6 & 1 & 6 & 1 & 6 & 1 & 8 & 2 & 12 & 3 & 15 & 2 & 17 & 2 & 16 & 2 & 18 & 2 & 18 & 2 & 19 & 2 & 16 \\
\hline Bignoniaceae & 2 & 23 & 2 & 15 & 1 & 13 & 1 & 15 & 1 & 15 & 1 & 15 & 2 & 15 & 1 & 17 & 2 & 21 & 2 & 22 & 2 & 24 & 2 & 27 & 2 & 27 & 2 & 10 \\
\hline Burseraceae & 1 & 8 & & & & & & & & & & & 1 & 31 & 1 & 13 & 1 & 13 & 1 & 6 & 1 & 7 & 1 & 9 & 1 & 9 & 1 & 47 \\
\hline Calophyllaceae & 1 & 9 & 1 & 7 & 1 & 7 & 1 & 8 & 1 & 8 & 1 & 7 & 2 & 47 & 1 & 9 & 1 & 22 & 1 & 29 & 1 & 29 & 1 & 34 & 1 & 32 & 1 & 26 \\
\hline Caryocaraceae & 1 & 8 & 1 & 6 & 1 & 9 & 1 & 9 & 1 & 9 & 1 & 9 & 1 & 22 & 1 & 4 & 1 & 5 & 1 & 5 & 1 & 5 & 1 & 5 & 1 & 5 & 1 & 10 \\
\hline Celastraceae & 1 & 17 & 2 & 10 & 1 & 15 & 1 & 16 & 1 & 17 & 1 & 17 & 1 & 26 & 1 & 4 & 1 & 5 & 1 & 4 & 1 & 5 & 2 & 7 & 2 & 7 & 2 & 6 \\
\hline Combretaceae & & & & & & & & & & & & & 1 & 2 & & & & & & & & & & & & & & \\
\hline Connaraceae & 1 & 18 & 1 & 12 & 1 & 12 & 1 & 12 & 1 & 12 & 1 & 12 & 1 & 25 & 1 & 14 & 1 & 20 & 1 & 22 & 1 & 23 & 1 & 23 & 1 & 21 & 1 & 11 \\
\hline Dilleniaceae & & & & & & & & & & & & & & & & & 1 & 1 & & & & & & & & & & \\
\hline Ebenaceae & & & 1 & 1 & & & & & & & & & 1 & 4 & 1 & 1 & 1 & 3 & 1 & 3 & 1 & 3 & 1 & 4 & 1 & 5 & 1 & 3 \\
\hline Erythroxylaceae & 3 & 15 & 3 & 11 & 3 & 15 & 3 & 15 & 3 & 14 & 3 & 14 & 3 & 30 & 2 & 10 & 3 & 20 & 2 & 24 & 2 & 24 & 2 & 25 & 2 & 26 & 2 & 28 \\
\hline Euphorbiaceae & & & & & & & & & & & & & 1 & 10 & & & & & & & & & & & & & 1 & 1 \\
\hline Fabaceae & 11 & $\begin{array}{l}10 \\
7\end{array}$ & 9 & 77 & 9 & 92 & 9 & 101 & 9 & 97 & 9 & 91 & 14 & 186 & 10 & 99 & 12 & 158 & 10 & 146 & 10 & 148 & 10 & 156 & 10 & 161 & 12 & 200 \\
\hline Lamiaceae & 1 & 11 & 1 & 10 & 1 & 14 & 1 & 17 & 1 & 17 & 1 & 18 & & & 1 & 18 & 1 & 24 & 1 & 25 & 1 & 24 & 1 & 25 & 1 & 26 & & \\
\hline Lauraceae & & & & & & & & & & & & & & & & & & & & & & & & & & & 1 & 1 \\
\hline Loganiaceae & 1 & 8 & 1 & 7 & 1 & 6 & 1 & 6 & 1 & 6 & 1 & 6 & 1 & 11 & 1 & 4 & 1 & 4 & 1 & 6 & 1 & 7 & 1 & 7 & 1 & 7 & 1 & 8 \\
\hline Malpighiaceae & 2 & 11 & 2 & 19 & 2 & 18 & 2 & 18 & 2 & 19 & 2 & 20 & 4 & 32 & 2 & 17 & 3 & 23 & 2 & 23 & 2 & 25 & 2 & 27 & 2 & 27 & 3 & 20 \\
\hline Malvaceae & 1 & 2 & 1 & 1 & 1 & 3 & 1 & 3 & 1 & 3 & 1 & 3 & 1 & 8 & 1 & 2 & 1 & 3 & 1 & 3 & 1 & 3 & 1 & 3 & 1 & 3 & 1 & 3 \\
\hline
\end{tabular}




\begin{tabular}{|c|c|c|c|c|c|c|c|c|c|c|c|c|c|c|c|c|c|c|c|c|c|c|c|c|c|c|c|c|}
\hline \multirow[t]{3}{*}{ FAMÍLIA } & \multicolumn{14}{|c|}{ ÁREA 1} & \multicolumn{14}{|c|}{ ÁREA 2} \\
\hline & \multicolumn{2}{|c|}{1988} & \multicolumn{2}{|c|}{1990} & \multicolumn{2}{|c|}{1991} & \multicolumn{2}{|c|}{1992} & \multicolumn{2}{|c|}{1993} & \multicolumn{2}{|c|}{1994} & \multicolumn{2}{|c|}{2012} & \multicolumn{2}{|c|}{1988} & \multicolumn{2}{|c|}{1990} & \multicolumn{2}{|c|}{1991} & \multicolumn{2}{|c|}{1992} & \multicolumn{2}{|c|}{1993} & \multicolumn{2}{|c|}{1994} & \multicolumn{2}{|c|}{2012} \\
\hline & $S$ & $\mathrm{~N}$ & $S$ & $\mathrm{~N}$ & $S$ & $\mathrm{~N}$ & $\mathrm{~S}$ & $\mathrm{~N}$ & $S$ & $\mathrm{~N}$ & $S$ & $\mathrm{~N}$ & $S$ & $\mathrm{~N}$ & $S$ & $\mathrm{~N}$ & $\mathrm{~S}$ & $\mathrm{~N}$ & $\mathrm{~S}$ & $\mathrm{~N}$ & $S$ & $\mathrm{~N}$ & $\mathrm{~S}$ & $\mathrm{~N}$ & $\mathrm{~S}$ & $\mathrm{~N}$ & $\mathrm{~S}$ & $\mathrm{~N}$ \\
\hline Melastomataceae & 1 & 8 & 1 & 3 & 1 & 2 & 1 & 2 & 1 & 2 & 1 & 2 & 3 & 47 & & & & & & & & & & & & & 4 & 92 \\
\hline Moraceae & 1 & 2 & 1 & 1 & 1 & 1 & 1 & 1 & 1 & 1 & 1 & 1 & 1 & 4 & 1 & 1 & 1 & 1 & & & & & & & & & 1 & 1 \\
\hline Myrtaceae & 1 & 10 & 1 & 3 & 1 & 5 & 1 & 6 & 1 & 6 & 1 & 5 & 1 & 15 & 1 & 8 & 1 & 8 & 1 & 8 & 1 & 8 & 1 & 9 & 1 & 9 & 1 & 5 \\
\hline Nyctaginaceae & 2 & 91 & 2 & 20 & 3 & 26 & 3 & 33 & 3 & 23 & 3 & 24 & 3 & 224 & 2 & 62 & 3 & 107 & 3 & 107 & 3 & 108 & 3 & 119 & 3 & 121 & 3 & 85 \\
\hline Ochnaceae & 1 & 33 & 1 & 31 & 1 & 35 & 1 & 37 & 1 & 36 & 1 & 36 & 1 & 39 & 1 & 28 & 1 & 36 & 1 & 31 & 1 & 30 & 1 & 31 & 1 & 31 & 1 & 27 \\
\hline Primulaceae & 1 & 37 & 1 & 4 & 1 & 9 & 1 & 14 & 1 & 13 & 1 & 13 & 2 & 161 & 1 & 70 & 1 & 121 & 1 & 131 & 1 & 143 & 1 & 169 & 1 & 175 & 2 & 349 \\
\hline Proteaceae & 1 & 21 & 1 & 5 & 1 & 5 & 1 & 7 & 1 & 5 & 1 & 5 & 1 & 57 & 1 & 10 & 1 & 16 & 1 & 20 & 1 & 20 & 1 & 23 & 1 & 23 & 1 & 35 \\
\hline Rubiaceae & 4 & 22 & 2 & 5 & 2 & 7 & 2 & 7 & 2 & 7 & 2 & 7 & 4 & 51 & 3 & 10 & 3 & 17 & 3 & 20 & 2 & 16 & 3 & 31 & 3 & 32 & 4 & 33 \\
\hline Rutaceae & & & & & & & & & & & & & 1 & 4 & & & & & & & & & & & & & & \\
\hline Salicaceae & 1 & 5 & 1 & 1 & 1 & 1 & 1 & 1 & 1 & 1 & 1 & 1 & 1 & 1 & 1 & 1 & 1 & 4 & 1 & 4 & 1 & 4 & 1 & 5 & 1 & 4 & 1 & 1 \\
\hline Sapotaceae & 1 & 7 & 1 & 5 & 1 & 5 & 1 & 5 & 1 & 5 & 1 & 5 & 1 & 8 & 1 & 3 & 1 & 3 & 1 & 3 & 1 & 3 & 1 & 3 & 1 & 3 & 1 & 2 \\
\hline Styracaceae & 1 & 54 & 1 & 26 & 1 & 32 & 1 & 40 & 1 & 40 & 1 & 38 & 1 & 43 & 1 & 27 & 1 & 42 & 1 & 40 & 1 & 42 & 1 & 47 & 1 & 47 & 1 & 24 \\
\hline Symplocaceae & 1 & 2 & 1 & 2 & 1 & 2 & 1 & 2 & 1 & 2 & 1 & 2 & & & & & & & & & & & & & & & & \\
\hline Velloziaceae & 1 & 13 & 1 & 15 & 1 & 15 & 1 & 15 & 1 & 15 & 1 & 15 & 1 & 2 & 1 & 15 & 1 & 18 & 1 & 16 & 1 & 16 & 1 & 16 & 1 & 16 & 1 & 3 \\
\hline Vochysiaceae & 3 & 20 & 3 & 18 & 3 & 18 & 3 & 20 & 3 & 19 & 3 & 19 & 3 & 24 & 2 & 5 & 2 & 5 & 2 & 5 & 2 & 5 & 2 & 6 & 2 & 6 & 3 & 9 \\
\hline Total Geral & 54 & $\begin{array}{l}65 \\
6 \\
\end{array}$ & 49 & 383 & 49 & 446 & 49 & 490 & 49 & 476 & 49 & 471 & 68 & 1288 & 49 & 509 & 56 & 783 & 50 & 790 & 49 & 812 & 51 & 910 & 50 & 924 & 63 & 1206 \\
\hline
\end{tabular}


Apêndice 3 - Número de indivíduos (N) e Riqueza (S) por parcela em duas áreas (Área 1, Área 2) em Cerrado sentido restrito, com diferentes históricos de queimadas, no período de 1988 a 2012. Onde: Área 1= com queimadas bienais de 1988 a 1992, e proteção do fogo de 1995 a 2012 ; Área 2 = protegida contra o fogo de 1988 a julho de 1994, e de 1995 a 2012 . Obs.: em 1988 as parcelas eram de $10 \mathrm{mx} 20 \mathrm{~m}$ e de 1990 a 2012 as parcelas eram de 10mx10m; o levantamento dos dados, em 1994, ocorreu antes do fogo acidental que atingiu as duas áreas em agosto.

\begin{tabular}{|c|c|c|c|c|c|c|c|c|c|c|c|c|c|c|c|}
\hline \multirow[t]{2}{*}{ Área } & \multirow[t]{2}{*}{ Parcela } & \multicolumn{2}{|c|}{1988} & \multicolumn{2}{|c|}{1990} & \multicolumn{2}{|c|}{1991} & \multicolumn{2}{|c|}{1992} & \multicolumn{2}{|c|}{1993} & \multicolumn{2}{|c|}{1994} & \multicolumn{2}{|c|}{2012} \\
\hline & & $\mathrm{N}$ & $S$ & $\mathrm{~N}$ & $S$ & $\mathrm{~N}$ & $S$ & $\mathrm{~N}$ & $S$ & $\mathrm{~N}$ & $S$ & $\mathrm{~N}$ & $S$ & $\mathrm{~N}$ & $S$ \\
\hline 1 & 1 & 49 & 22 & 18 & 12 & 24 & 17 & 24 & 17 & 23 & 16 & 23 & 16 & 49 & 26 \\
\hline 1 & 2 & 72 & 26 & 24 & 15 & 28 & 16 & 29 & 17 & 28 & 16 & 28 & 16 & 65 & 28 \\
\hline 1 & 3 & 69 & 31 & 23 & 13 & 31 & 19 & 31 & 19 & 31 & 19 & 30 & 19 & 83 & 32 \\
\hline 1 & 4 & 60 & 19 & 19 & 15 & 22 & 17 & 25 & 17 & 25 & 17 & 26 & 18 & 76 & 26 \\
\hline 1 & 5 & 65 & 28 & 27 & 15 & 37 & 21 & 37 & 21 & 38 & 20 & 36 & 19 & 76 & 25 \\
\hline 1 & 6 & 78 & 30 & 17 & 15 & 17 & 15 & 19 & 16 & 19 & 16 & 18 & 15 & 74 & 25 \\
\hline 1 & 7 & 60 & 25 & 17 & 9 & 21 & 14 & 27 & 14 & 26 & 14 & 24 & 14 & 68 & 24 \\
\hline 1 & 8 & 62 & 30 & 5 & 5 & 9 & 8 & 11 & 9 & 10 & 9 & 10 & 9 & 63 & 27 \\
\hline 1 & 9 & 64 & 26 & 26 & 10 & 29 & 13 & 35 & 15 & 36 & 15 & 37 & 15 & 48 & 21 \\
\hline 1 & 10 & 77 & 32 & 12 & 8 & 15 & 11 & 14 & 10 & 14 & 10 & 14 & 10 & 57 & 23 \\
\hline 1 & 11 & & & 22 & 17 & 19 & 15 & 25 & 17 & 29 & 19 & 34 & 21 & 54 & 28 \\
\hline 1 & 12 & & & 26 & 17 & 22 & 17 & 27 & 19 & 23 & 17 & 23 & 17 & 44 & 21 \\
\hline 1 & 13 & & & 14 & 9 & 19 & 14 & 20 & 15 & 16 & 12 & 16 & 12 & 79 & 35 \\
\hline 1 & 14 & & & 11 & 10 & 14 & 14 & 14 & 12 & 13 & 11 & 12 & 11 & 79 & 31 \\
\hline 1 & 15 & & & 14 & 11 & 16 & 12 & 19 & 15 & 18 & 14 & 18 & 14 & 56 & 23 \\
\hline 1 & 16 & & & 18 & 14 & 25 & 20 & 26 & 21 & 26 & 21 & 23 & 19 & 66 & 34 \\
\hline 1 & 17 & & & 19 & 10 & 17 & 10 & 22 & 12 & 21 & 12 & 20 & 11 & 45 & 22 \\
\hline 1 & 18 & & & 18 & 14 & 22 & 14 & 24 & 16 & 23 & 16 & 22 & 15 & 78 & 28 \\
\hline 1 & 19 & & & 30 & 18 & 34 & 18 & 34 & 18 & 33 & 18 & 34 & 19 & 68 & 27 \\
\hline 1 & 20 & 47 & 21 & 23 & 12 & 25 & 12 & 27 & 13 & 24 & 13 & 23 & 13 & 60 & 25 \\
\hline 2 & 21 & 50 & 21 & 32 & 14 & 37 & 18 & 41 & 18 & 51 & 23 & 57 & 24 & 66 & 19 \\
\hline 2 & 22 & 34 & 14 & 30 & 14 & 31 & 16 & 36 & 18 & 45 & 22 & 46 & 22 & 81 & 26 \\
\hline 2 & 23 & 57 & 20 & 36 & 17 & 35 & 19 & 37 & 19 & 38 & 19 & 39 & 18 & 67 & 27 \\
\hline 2 & 24 & 46 & 23 & 29 & 13 & 34 & 17 & 35 & 17 & 36 & 18 & 38 & 19 & 49 & 18 \\
\hline
\end{tabular}




\begin{tabular}{|c|c|c|c|c|c|c|c|c|c|c|c|c|c|c|c|}
\hline \multirow[t]{2}{*}{ Área } & \multirow[t]{2}{*}{ Parcela } & \multicolumn{2}{|c|}{1988} & \multicolumn{2}{|c|}{1990} & \multicolumn{2}{|c|}{1991} & \multicolumn{2}{|c|}{1992} & \multicolumn{2}{|c|}{1993} & \multicolumn{2}{|c|}{1994} & \multicolumn{2}{|c|}{2012} \\
\hline & & $\mathrm{N}$ & $\mathrm{S}$ & $\mathrm{N}$ & $\mathrm{S}$ & $\mathrm{N}$ & $\mathrm{S}$ & $\mathrm{N}$ & $\mathrm{S}$ & $\mathrm{N}$ & $\mathrm{S}$ & $\mathrm{N}$ & $\mathrm{S}$ & $\mathrm{N}$ & $S$ \\
\hline 2 & 25 & 49 & 20 & 24 & 13 & 30 & 14 & 31 & 14 & 33 & 16 & 35 & 17 & 58 & 17 \\
\hline 2 & 26 & 63 & 25 & 30 & 16 & 33 & 16 & 34 & 17 & 35 & 18 & 39 & 18 & 61 & 18 \\
\hline 2 & 27 & 57 & 26 & 32 & 13 & 36 & 13 & 36 & 13 & 41 & 13 & 41 & 13 & 59 & 19 \\
\hline 2 & 28 & 57 & 26 & 58 & 22 & 58 & 24 & 56 & 24 & 58 & 24 & 58 & 24 & 70 & 23 \\
\hline 2 & 29 & 49 & 24 & 37 & 19 & 35 & 20 & 35 & 18 & 34 & 17 & 34 & 17 & 39 & 20 \\
\hline 2 & 30 & & & 27 & 16 & 32 & 18 & 32 & 18 & 32 & 18 & 33 & 18 & 54 & 23 \\
\hline 2 & 31 & & & 31 & 17 & 34 & 18 & 35 & 18 & 38 & 17 & 39 & 17 & 59 & 20 \\
\hline 2 & 32 & & & 66 & 25 & 62 & 21 & 67 & 23 & 73 & 23 & 71 & 23 & 77 & 23 \\
\hline 2 & 33 & & & 49 & 24 & 45 & 21 & 48 & 21 & 54 & 21 & 52 & 20 & 67 & 28 \\
\hline 2 & 34 & & & 53 & 24 & 48 & 23 & 51 & 23 & 61 & 24 & 59 & 24 & 54 & 19 \\
\hline 2 & 35 & & & 50 & 23 & 42 & 18 & 43 & 18 & 49 & 21 & 48 & 21 & 39 & 18 \\
\hline 2 & 36 & & & 39 & 22 & 42 & 22 & 43 & 22 & 53 & 23 & 55 & 23 & 59 & 27 \\
\hline 2 & 37 & & & 39 & 20 & 38 & 19 & 37 & 19 & 43 & 20 & 43 & 20 & 61 & 30 \\
\hline 2 & 38 & & & 38 & 21 & 39 & 21 & 38 & 20 & 44 & 23 & 45 & 24 & 58 & 24 \\
\hline 2 & 39 & & & 47 & 27 & 42 & 21 & 40 & 19 & 51 & 21 & 51 & 21 & 71 & 26 \\
\hline 2 & 40 & & & 36 & 16 & 37 & 17 & 37 & 17 & 41 & 20 & 41 & 20 & 57 & 23 \\
\hline
\end{tabular}


Apêndice 4 - Parâmetros fitossociológicos de espécies arbóreo-arbustivas na Área 1, em Cerrado sentido restrito em Planaltina (DF), em seis ocasiões do monitoramento, em ordem do IVI do ano de 1990, onde: DR= Densidade relativa (\%); FR= Frequência relativa (\%); Do= Dominância Relativa (\%); IVI= Índice de valor de Importância (\%). Obs.: área com queimadas bienais em 1988, 1990 e 1992, e proteção contra o fogo de 1995 a 2012; em 1994, o levantamento dos dados foi feito antes do fogo acidental que atingiu as duas áreas em agosto.

\begin{tabular}{|c|c|c|c|c|c|c|c|c|c|c|c|c|c|c|c|c|c|c|c|c|c|c|c|c|}
\hline \multirow[t]{2}{*}{ Espécies } & \multicolumn{4}{|c|}{1990} & \multicolumn{4}{|c|}{1991} & \multicolumn{4}{|c|}{1992} & \multicolumn{4}{|c|}{1993} & \multicolumn{4}{|c|}{1994} & \multicolumn{4}{|c|}{2012} \\
\hline & DR & FR & Do & IVI & DR & FR & Do & IVI & DR & FR & Do & IVI & $\overline{D R}$ & FR & Do & IVI & $\overline{D R}$ & FR & Do & IVI & DR & FR & Do & IVI \\
\hline $\begin{array}{l}\text { Vellozia } \\
\text { squamata }\end{array}$ & 3,9 & 4,4 & 13,3 & 21,6 & 3,4 & 3,7 & 13,9 & 21,0 & 3,1 & 3,5 & 10,9 & 17,5 & 4,0 & 4,2 & 13,4 & 21,6 & 3,9 & 4,1 & 14,1 & 22,1 & 0,2 & 0,4 & 3,1 & 3,6 \\
\hline $\begin{array}{l}\text { Ouratea } \\
\text { hexasperma }\end{array}$ & 8,1 & 5,2 & 8,0 & 21,3 & 7,9 & 5,1 & 9,1 & 22,0 & 7,6 & 5,1 & 8,2 & 20,9 & 9,4 & 6,1 & 9,1 & 24,6 & 8,7 & 5,9 & 9,1 & 23,8 & 3,0 & 3,0 & 5,4 & 11,4 \\
\hline Syagrus flexuosa & 8,9 & 5,6 & 5,8 & 20,3 & 8,1 & 4,7 & 5,5 & 18,3 & 7,4 & 4,5 & 5,7 & 17,6 & 10,7 & 5,8 & 6,8 & 23,3 & 10,3 & 5,6 & 6,4 & 22,2 & 0,7 & 0,6 & 0,8 & 2,0 \\
\hline $\begin{array}{l}\text { Styrax } \\
\text { ferrugineus }\end{array}$ & 6,8 & 5,2 & 5,9 & 17,9 & 7,0 & 5,4 & 5,8 & 18,1 & 8,2 & 5,8 & 6,8 & 20,8 & 6,7 & 6,5 & 5,9 & 19,1 & 6,9 & 5,9 & 6,0 & 18,9 & 3,3 & 3,2 & 6,7 & 13,3 \\
\hline Guapira noxia & 4,2 & 3,6 & 7,8 & 15,6 & 4,0 & 3,4 & 7,4 & 14,8 & 3,3 & 2,9 & 7,1 & 13,3 & 2,4 & 2,7 & 5,3 & 10,4 & 2,8 & 3,3 & 5,6 & 11,7 & 1,3 & 2,5 & 3,0 & 6,8 \\
\hline $\begin{array}{l}\text { Dalbergia } \\
\text { miscolobium }\end{array}$ & 4,7 & 4,4 & 4,5 & 13,6 & 4,3 & 4,0 & 4,9 & 13,2 & 4,1 & 4,2 & 5,1 & 13,4 & 4,8 & 4,6 & 5,0 & 14,4 & 3,9 & 4,1 & 4,0 & 11,9 & 1,9 & 2,1 & 2,9 & 6,8 \\
\hline $\begin{array}{l}\text { Byrsonima } \\
\text { verbascifolia }\end{array}$ & 4,4 & 4,4 & 3,9 & 12,8 & 3,6 & 3,7 & 3,4 & 10,7 & 3,3 & 3,5 & 3,6 & 10,4 & 4,6 & 4,2 & 4,2 & 12,9 & 4,6 & 4,4 & 4,3 & 13,3 & 0,5 & 1,1 & 1,2 & 2,9 \\
\hline $\begin{array}{l}\text { Tachigali } \\
\text { subvelutina }\end{array}$ & 3,9 & 4,8 & 3,4 & 12,1 & 4,3 & 4,4 & 4,5 & 13,2 & 4,5 & 4,5 & 5,7 & 14,7 & 5,1 & 5,0 & 6,0 & 16,0 & 5,1 & 4,8 & 7,0 & 16,9 & 1,9 & 2,6 & 18,4 & 23,0 \\
\hline Vochysia elliptica & 3,4 & 2,8 & 4,2 & 10,4 & 2,9 & 2,4 & 2,8 & 8,0 & 2,9 & 2,6 & 2,9 & 8,3 & 3,2 & 2,3 & 2,4 & 7,9 & 3,1 & 2,2 & 2,6 & 7,9 & 1,0 & 1,7 & 1,1 & 3,8 \\
\hline $\begin{array}{l}\text { Schefflera } \\
\text { macrocarpa }\end{array}$ & 3,1 & 3,6 & 2,8 & 9,5 & 3,1 & 3,4 & 2,2 & 8,7 & 2,9 & 3,2 & 2,2 & 8,3 & 3,5 & 3,5 & 2,7 & 9,6 & 3,3 & 3,3 & 2,8 & 9,4 & 2,1 & 2,1 & 2,5 & 6,7 \\
\hline $\begin{array}{l}\text { Connarus } \\
\text { suberosus }\end{array}$ & 3,1 & 4,0 & 2,3 & 9,4 & 2,7 & 3,4 & 2,5 & 8,6 & 2,5 & 3,2 & 2,5 & 8,2 & 2,9 & 3,8 & 2,5 & 9,3 & 3,1 & 3,7 & 2,5 & 9,2 & 1,9 & 2,8 & 1,5 & 6,3 \\
\hline $\begin{array}{l}\text { Machaerium } \\
\text { opacum }\end{array}$ & 3,4 & 2,4 & 2,8 & 8,6 & 2,0 & 2,7 & 1,6 & 6,3 & 2,5 & 2,3 & 1,8 & 6,5 & 1,9 & 2,3 & 1,7 & 5,8 & 1,8 & 2,2 & 1,7 & 5,8 & 2,6 & 3,0 & 3,1 & 8,6 \\
\hline $\begin{array}{l}\text { Handroanthus } \\
\text { ochraceus }\end{array}$ & 3,4 & 2,8 & 1,3 & 7,5 & 2,9 & 3,0 & 1,3 & 7,2 & 3,1 & 3,2 & 1,5 & 7,8 & 3,5 & 3,5 & 1,6 & 8,5 & 3,1 & 3,3 & 1,4 & 7,8 & 0,9 & 1,5 & 0,4 & 2,8 \\
\hline $\begin{array}{l}\text { Aspidosperma } \\
\text { tomentosum }\end{array}$ & 2,4 & 3,2 & 1,6 & 7,2 & 1,1 & 1,7 & 0,5 & 3,3 & 1,2 & 1,9 & 0,5 & 3,7 & 1,1 & 1,5 & 0,5 & 3,1 & 1,0 & 1,5 & 0,4 & 2,9 & 1,1 & 1,9 & 1,1 & 4,1 \\
\hline $\begin{array}{l}\text { Caryocar } \\
\text { brasiliense }\end{array}$ & 1,6 & 2,0 & 3,4 & 7,0 & 2,0 & 2,0 & 3,5 & 7,5 & 1,8 & 1,9 & 3,4 & 7,1 & 1,3 & 1,9 & 3,1 & 6,3 & 1,3 & 1,9 & 3,0 & 6,1 & 1,7 & 2,3 & 4,0 & 8,0 \\
\hline $\begin{array}{l}\text { Leptolobium } \\
\text { dasycarpum }\end{array}$ & 2,1 & 2,4 & 2,3 & 6,8 & 2,0 & 2,0 & 2,4 & 6,5 & 1,8 & 1,9 & 2,2 & 5,9 & 1,9 & 1,9 & 2,7 & 6,5 & 1,8 & 1,9 & 2,1 & 5,7 & 1,9 & 2,1 & 1,9 & 5,9 \\
\hline $\begin{array}{l}\text { Vochysia } \\
\text { thyrsoidea }\end{array}$ & 0,8 & 0,8 & 4,7 & 6,2 & 0,7 & 0,7 & 4,2 & 5,6 & 0,6 & 0,6 & 3,1 & 4,3 & 0,8 & 0,8 & 4,4 & 5,9 & 0,8 & 0,7 & 4,1 & 5,6 & 0,2 & 0,4 & 3,6 & 4,2 \\
\hline $\begin{array}{l}\text { Annona } \\
\text { crassiflora }\end{array}$ & 1,3 & 0,8 & 3,6 & 5,7 & 1,6 & 1,4 & 3,6 & 6,5 & 1,2 & 1,0 & 3,2 & 5,4 & 1,6 & 1,2 & 3,5 & 6,2 & 1,5 & 1,1 & 3,6 & 6,2 & 0,7 & 0,9 & 2,5 & 4,1 \\
\hline $\begin{array}{l}\text { Plenckia } \\
\text { populnea }\end{array}$ & 2,1 & 2,4 & 1,0 & 5,5 & 3,4 & 3,4 & 1,7 & 8,5 & 3,3 & 3,5 & 4,1 & 11,0 & 3,7 & 3,8 & 1,8 & 9,4 & 3,6 & 3,7 & 1,8 & 9,1 & 2,0 & 2,6 & 1,0 & 5,7 \\
\hline $\begin{array}{l}\text { Hymenaea } \\
\text { stigonocarpa }\end{array}$ & 1,6 & 2,4 & 1,5 & 5,5 & 1,4 & 2,0 & 1,4 & 4,8 & 1,4 & 2,3 & 1,5 & 5,1 & 1,9 & 2,7 & 1,5 & 6,1 & 1,8 & 2,6 & 1,5 & 5,9 & 0,6 & 1,3 & 1,0 & 2,9 \\
\hline
\end{tabular}




\begin{tabular}{|c|c|c|c|c|c|c|c|c|c|c|c|c|c|c|c|c|c|c|c|c|c|c|c|c|}
\hline \multirow[t]{2}{*}{ Espécies } & \multicolumn{4}{|c|}{1990} & \multicolumn{4}{|c|}{1991} & \multicolumn{4}{|c|}{1992} & \multicolumn{4}{|c|}{1993} & \multicolumn{4}{|c|}{1994} & \multicolumn{4}{|c|}{2012} \\
\hline & DR & FR & Do & IVI & DR & FR & Do & IVI & DR & FR & Do & IVI & DR & FR & Do & IVI & DR & FR & Do & IVI & DR & FR & Do & IVI \\
\hline $\begin{array}{l}\text { Aegiphila } \\
\text { verticillata }\end{array}$ & 2,6 & 2,4 & 0,3 & 5,4 & 3,1 & 2,7 & 0,4 & 6,3 & 3,5 & 2,9 & 0,6 & 7,0 & 2,7 & 2,7 & 0,4 & 5,8 & 3,1 & 3,0 & 0,5 & 6,5 & & & & \\
\hline $\begin{array}{l}\text { Strychnos } \\
\text { pseudoquina }\end{array}$ & 1,8 & 2,0 & 1,4 & 5,3 & 1,6 & 1,4 & 1,4 & 4,3 & 1,2 & 1,0 & 0,8 & 3,0 & 1,3 & 1,2 & 0,8 & 3,2 & 1,3 & 1,1 & 0,7 & 3,1 & 0,9 & 1,1 & 1,0 & 2,9 \\
\hline $\begin{array}{l}\text { Kielmeyera } \\
\text { coriacea }\end{array}$ & 1,8 & 2,0 & 1,0 & 4,8 & 1,6 & 1,7 & 0,8 & 4,0 & 1,6 & 1,9 & 0,8 & 4,4 & 1,9 & 2,3 & 0,9 & 5,1 & 1,5 & 1,9 & 0,5 & 3,9 & 3,6 & 3,6 & 1,7 & 8,8 \\
\hline $\begin{array}{l}\text { Symplocos } \\
\text { rhamnifolia }\end{array}$ & 0,5 & 0,8 & 3,2 & 4,6 & 0,5 & 0,7 & 2,9 & 4,1 & 0,4 & 0,6 & 2,8 & 3,9 & 0,5 & 0,8 & 3,0 & 4,3 & 0,5 & 0,7 & 3,1 & 4,4 & & & & \\
\hline $\begin{array}{l}\text { Stryphnodendron } \\
\text { adstringens }\end{array}$ & 1,3 & 2,0 & 1,2 & 4,5 & 2,0 & 2,0 & 1,0 & 5,0 & 1,8 & 1,9 & 1,1 & 4,8 & 1,9 & 2,3 & 1,1 & 5,3 & 1,8 & 2,2 & 1,1 & 5,2 & 2,1 & 2,5 & 3,3 & 7,8 \\
\hline $\begin{array}{l}\text { Dimorphandra } \\
\text { mollis }\end{array}$ & 1,3 & 2,0 & 0,9 & 4,2 & 2,5 & 3,4 & 1,1 & 7,0 & 2,3 & 3,2 & 1,1 & 6,6 & 1,6 & 2,3 & 0,6 & 4,6 & 1,8 & 2,6 & 0,7 & 5,1 & 0,6 & 1,1 & 0,6 & 2,4 \\
\hline $\begin{array}{l}\text { Piptocarpha } \\
\text { rotundifolia }\end{array}$ & 1,6 & 1,6 & 0,9 & 4,1 & 1,4 & 1,7 & 0,5 & 3,6 & 1,2 & 1,6 & 0,6 & 3,4 & 1,3 & 1,9 & 0,7 & 3,9 & 1,8 & 2,2 & 0,8 & 4,8 & 0,9 & 1,7 & 1,7 & 4,2 \\
\hline $\begin{array}{l}\text { Erythroxylum } \\
\text { campestre }\end{array}$ & 1,6 & 1,6 & 0,6 & 3,8 & 0,5 & 0,7 & 0,1 & 1,2 & 0,4 & 0,6 & 0,1 & 1,2 & & & & & & & & & & & & \\
\hline $\begin{array}{l}\text { Pouteria } \\
\text { ramiflora }\end{array}$ & 1,3 & 1,6 & 0,6 & 3,6 & 1,1 & 1,4 & 0,6 & 3,1 & 1,0 & 1,3 & 0,6 & 2,9 & 1,3 & 1,5 & 0,7 & 3,5 & 1,3 & 1,5 & 0,7 & 3,4 & 0,6 & 0,8 & 0,7 & 2,1 \\
\hline $\begin{array}{l}\text { Mimosa } \\
\text { claussenii }\end{array}$ & 1,3 & 1,6 & 0,5 & 3,4 & 1,4 & 1,4 & 0,4 & 3,1 & 1,2 & 1,3 & 0,5 & 3,0 & 0,5 & 0,8 & 0,2 & 1,5 & 0,3 & 0,4 & 0,1 & 0,8 & 0,4 & 0,4 & 0,2 & 0,9 \\
\hline Roupala montana & 1,3 & 1,6 & 0,2 & 3,1 & 1,1 & 1,4 & 0,3 & 2,7 & 1,4 & 1,9 & 0,3 & 3,7 & 0,8 & 1,2 & 0,2 & 2,2 & 0,8 & 1,1 & 0,3 & 2,2 & 4,4 & 3,4 & 2,3 & 10,2 \\
\hline $\begin{array}{l}\text { Myrsine } \\
\text { guianensis }\end{array}$ & 1,0 & 1,2 & 0,5 & 2,7 & 2,0 & 2,4 & 0,3 & 4,7 & 2,9 & 2,3 & 0,4 & 5,5 & & & & & 0,3 & 0,4 & 0,0 & 0,6 & 12,3 & 3,8 & 3,5 & 19,6 \\
\hline Miconia fallax & 0,8 & 1,2 & 0,7 & 2,7 & 0,5 & 0,7 & 0,7 & 1,9 & 0,4 & 0,6 & 0,7 & 1,8 & 0,5 & 0,8 & 0,7 & 2,0 & 0,5 & 0,7 & 0,7 & 1,9 & 0,4 & 0,8 & 0,1 & 1,2 \\
\hline Palicourea rigida & 0,8 & 1,2 & 0,5 & 2,5 & 0,5 & 0,7 & 0,4 & 1,5 & 0,4 & 0,6 & 0,4 & 1,4 & 0,5 & 0,8 & 0,3 & 1,6 & 0,3 & 0,4 & 0,0 & 0,6 & 1,9 & 3,0 & 1,3 & 6,2 \\
\hline $\begin{array}{l}\text { Guapira } \\
\text { graciliflora }\end{array}$ & 1,0 & 1,2 & 0,2 & 2,5 & 1,1 & 1,7 & 0,3 & 3,1 & 2,7 & 2,6 & 0,5 & 5,7 & 0,5 & 0,8 & 0,2 & 1,5 & 1,3 & 1,5 & 0,2 & 3,0 & 14,0 & 3,6 & 4,8 & 22,4 \\
\hline $\begin{array}{l}\text { Byrsonima } \\
\text { coccolobifolia }\end{array}$ & 0,5 & 0,8 & 0,9 & 2,2 & 0,5 & 0,7 & 0,9 & 2,0 & 0,4 & 0,6 & 1,1 & 2,1 & 0,5 & 0,8 & 1,0 & 2,3 & 0,5 & 0,7 & 0,9 & 2,2 & 0,8 & 1,3 & 0,6 & 2,7 \\
\hline $\begin{array}{l}\text { Psidium } \\
\text { laruotteanum }\end{array}$ & 0,8 & 1,2 & 0,1 & 2,1 & 1,1 & 1,4 & 0,3 & 2,8 & 1,2 & 1,6 & 0,4 & 3,2 & 1,3 & 1,9 & 0,4 & 3,6 & 1,0 & 1,5 & 0,2 & 2,7 & 1,2 & 1,7 & 0,4 & 3,3 \\
\hline Qualea multiflora & 0,5 & 0,4 & 1,1 & 2,1 & 0,5 & 0,3 & 1,0 & 1,8 & 0,6 & 0,3 & 1,0 & 1,9 & 0,5 & 0,4 & 0,9 & 1,9 & 0,5 & 0,4 & 1,1 & 1,9 & & & & \\
\hline $\begin{array}{l}\text { Aspidosperma } \\
\text { macrocarpum }\end{array}$ & 0,5 & 0,8 & 0,4 & 1,7 & 1,8 & 2,4 & 1,5 & 5,7 & 1,8 & 2,3 & 1,7 & 5,8 & 1,6 & 2,3 & 1,6 & 5,5 & 2,1 & 2,6 & 1,6 & 6,3 & 1,7 & 1,9 & 0,6 & 4,1 \\
\hline $\begin{array}{l}\text { Erythroxylum } \\
\text { deciduum }\end{array}$ & 1,0 & 0,4 & 0,2 & 1,7 & 1,4 & 1,4 & 0,6 & 3,3 & 1,2 & 1,3 & 0,7 & 3,2 & 1,3 & 1,5 & 0,6 & 3,5 & 1,5 & 1,5 & 0,7 & 3,7 & 1,9 & 1,5 & 2,0 & 5,3 \\
\hline $\begin{array}{l}\text { Plathymenia } \\
\text { reticulata }\end{array}$ & 0,5 & 0,8 & 0,1 & 1,5 & 0,9 & 1,0 & 0,2 & 2,1 & 0,6 & 0,6 & 0,1 & 1,4 & & & & & 0,8 & 0,7 & 0,2 & 1,7 & 0,2 & 0,4 & 0,0 & 0,6 \\
\hline $\begin{array}{l}\text { Salacia } \\
\text { crassifolia }\end{array}$ & 0,5 & 0,8 & 0,0 & 1,4 & & & & & & & & & & & & & & & & & & & & \\
\hline Zeyheria montana & 0,5 & 0,8 & 0,0 & 1,4 & & & & & & & & & & & & & & & & & 0,2 & 0,6 & 0,0 & 0,8 \\
\hline
\end{tabular}




\begin{tabular}{|c|c|c|c|c|c|c|c|c|c|c|c|c|c|c|c|c|c|c|c|c|c|c|c|c|}
\hline \multirow[t]{2}{*}{ Espécies } & \multicolumn{4}{|c|}{1990} & \multicolumn{4}{|c|}{1991} & \multicolumn{4}{|c|}{1992} & \multicolumn{4}{|c|}{1993} & \multicolumn{4}{|c|}{1994} & \multicolumn{4}{|c|}{2012} \\
\hline & DR & FR & Do & IVI & DR & FR & Do & IVI & DR & FR & Do & IVI & DR & FR & Do & IVI & DR & FR & Do & IVI & DR & FR & Do & IVI \\
\hline $\begin{array}{l}\text { Eriotheca } \\
\text { pubescens }\end{array}$ & 0,3 & 0,4 & 0,3 & 1,0 & 0,7 & 1,0 & 0,5 & 2,2 & 0,6 & 1,0 & 0,5 & 2,1 & 0,8 & 1,2 & 0,5 & 2,5 & 0,8 & 1,1 & 0,6 & 2,4 & 0,6 & 1,1 & 0,8 & 2,5 \\
\hline $\begin{array}{l}\text { Tocoyena } \\
\text { formosa }\end{array}$ & 0,5 & 0,4 & 0,0 & 1,0 & 1,1 & 1,4 & 0,4 & 2,9 & 1,0 & 1,3 & 0,2 & 2,5 & 1,1 & 1,2 & 0,2 & 2,4 & 1,5 & 1,9 & 0,2 & 3,6 & 0,2 & 0,4 & 0,1 & 0,6 \\
\hline $\begin{array}{l}\text { Erythroxylum } \\
\text { tortuosum }\end{array}$ & 0,3 & 0,4 & 0,1 & 0,7 & & & & & & & & & & & & & & & & & 0,1 & 0,2 & 0,0 & 0,3 \\
\hline $\begin{array}{l}\text { Brosimum } \\
\text { gaudichaudii }\end{array}$ & 0,3 & 0,4 & 0,0 & 0,7 & 0,2 & 0,3 & 0,0 & 0,6 & 0,2 & 0,3 & 0,0 & 0,5 & & & & & & & & & 0,3 & 0,6 & 0,1 & 0,9 \\
\hline Diospyros hispida & 0,3 & 0,4 & 0,0 & 0,7 & & & & & & & & & & & & & & & & & 0,3 & 0,4 & 0,2 & 0,9 \\
\hline $\begin{array}{l}\text { Casearia } \\
\text { sylvestris }\end{array}$ & 0,3 & 0,4 & 0,0 & 0,7 & 0,2 & 0,3 & 0,1 & 0,6 & 0,2 & 0,3 & 0,1 & 0,6 & & & & & 0,3 & 0,4 & 0,1 & 0,7 & 0,1 & 0,2 & 0,0 & 0,3 \\
\hline Annona monticola & & & & & 0,5 & 0,7 & 0,0 & 1,1 & 0,4 & 0,6 & 0,0 & 1,1 & 0,3 & 0,4 & 0,0 & 0,7 & 0,3 & 0,4 & 0,0 & 0,6 & 1,2 & 2,1 & 0,1 & 3,4 \\
\hline $\begin{array}{l}\text { Annona } \\
\text { tomentosa }\end{array}$ & & & & & & & & & & & & & & & & & & & & & 3,9 & 3,2 & 0,4 & 7,5 \\
\hline Bauhinia dumosa & & & & & & & & & & & & & & & & & & & & & 1,4 & 1,9 & 0,1 & 3,4 \\
\hline Bauhinia rufa & & & & & & & & & & & & & & & & & & & & & 0,2 & 0,6 & 0,0 & 0,8 \\
\hline $\begin{array}{l}\text { Byrsonima } \\
\text { basiloba }\end{array}$ & & & & & & & & & & & & & & & & & & & & & 0,2 & 0,4 & 0,1 & 0,7 \\
\hline $\begin{array}{l}\text { Chomelia } \\
\text { ribesioides }\end{array}$ & & & & & & & & & & & & & & & & & & & & & 0,4 & 0,8 & 0,1 & 1,3 \\
\hline Cordiera sessilis & & & & & & & & & & & & & & & & & & & & & 1,6 & 0,6 & 0,3 & 2,5 \\
\hline $\begin{array}{l}\text { Cybianthus } \\
\text { gardneri }\end{array}$ & & & & & & & & & & & & & & & & & & & & & 0,2 & 0,6 & 0,6 & 1,4 \\
\hline $\begin{array}{l}\text { Enterolobium } \\
\text { gummiferum }\end{array}$ & & & & & & & & & & & & & & & & & & & & & 0,2 & 0,6 & 0,4 & 1,2 \\
\hline $\begin{array}{l}\text { Eremanthus } \\
\text { goyazensis }\end{array}$ & & & & & & & & & & & & & & & & & & & & & 0,1 & 0,2 & 0,0 & 0,3 \\
\hline $\begin{array}{l}\text { Erythroxylum } \\
\text { suberosum }\end{array}$ & & & & & 1,6 & 2,0 & 0,5 & 4,1 & 1,4 & 1,9 & 0,5 & 3,9 & 1,3 & 1,9 & 0,4 & 3,7 & 1,3 & 1,9 & 0,4 & 3,6 & 0,4 & 0,9 & 0,4 & 1,7 \\
\hline $\begin{array}{l}\text { Esenbeckia } \\
\text { pumila }\end{array}$ & & & & & & & & & & & & & & & & & & & & & 0,3 & 0,8 & 0,0 & 1,1 \\
\hline $\begin{array}{l}\text { Hancornia } \\
\text { speciosa }\end{array}$ & & & & & 0,2 & 0,3 & 0,0 & 0,6 & 0,2 & 0,3 & 0,0 & 0,6 & 0,3 & 0,4 & 0,0 & 0,7 & 0,3 & 0,4 & 0,0 & 0,7 & 0,1 & 0,2 & 0,0 & 0,3 \\
\hline $\begin{array}{l}\text { Heteropterys } \\
\text { byrsonimifolia }\end{array}$ & & & & & & & & & & & & & & & & & & & & & 0,9 & 0,8 & 1,0 & 2,7 \\
\hline $\begin{array}{l}\text { Kielmeyera } \\
\text { speciosa }\end{array}$ & & & & & & & & & & & & & & & & & & & & & 0,1 & 0,2 & 0,0 & 0,3 \\
\hline $\begin{array}{l}\text { Machaerium } \\
\text { acutifolium }\end{array}$ & & & & & & & & & & & & & & & & & & & & & 0,3 & 0,4 & 0,4 & 1,1 \\
\hline $\begin{array}{l}\text { Maprounea } \\
\text { guianensis }\end{array}$ & & & & & & & & & & & & & & & & & & & & & 0,8 & 0,9 & 0,1 & 1,8 \\
\hline Miconia albicans & & & & & & & & & & & & & & & & & & & & & 1,3 & 2,3 & 0,3 & 3,9 \\
\hline
\end{tabular}




\begin{tabular}{|c|c|c|c|c|c|c|c|c|c|c|c|c|c|c|c|c|c|c|c|c|c|c|c|c|}
\hline \multirow[t]{2}{*}{ Espécies } & \multicolumn{4}{|c|}{1990} & \multicolumn{4}{|c|}{1991} & \multicolumn{4}{|c|}{1992} & \multicolumn{4}{|c|}{1993} & \multicolumn{4}{|c|}{1994} & \multicolumn{4}{|c|}{2012} \\
\hline & DR & & Do & IVI & DR & FR & Do & IVI & DR & FR & Do & IVI & DR & FR & Do & IVI & DR & FR & Do & IVI & DR & FR & Do & IVI \\
\hline $\begin{array}{l}\text { Miconia } \\
\text { burchellii }\end{array}$ & & & & & & & & & & & & & & & & & & & & & 1,9 & 3,0 & 1,2 & 6,1 \\
\hline Neea theifera & & & & & 0,7 & 1,0 & 0,6 & 2,3 & 0,8 & 1,3 & 0,6 & 2,7 & 0,5 & 0,8 & 0,7 & 2,0 & 0,5 & 0,7 & 0,8 & 2,0 & 2,1 & 2,3 & 1,3 & 5,6 \\
\hline Protium ovatum & & & & & & & & & & & & & & & & & & & & & 2,4 & 2,8 & 0,3 & 5,5 \\
\hline Qualea parviflora & & & & & & & & & & & & & & & & & & & & & 0,6 & 0,6 & 1,4 & 2,6 \\
\hline Senna rugosa & & & & & & & & & & & & & & & & & & & & & 0,1 & 0,2 & 0,0 & 0,3 \\
\hline $\begin{array}{l}\text { Terminalia } \\
\text { fagifolia }\end{array}$ & & & & & & & & & & & & & & & & & & & & & 0,2 & 0,2 & 0,3 & 0,6 \\
\hline Total Geral & 100 & 100 & 100 & 300 & 100 & 100 & 100 & 300 & 100 & 100 & 100 & 300 & 100 & 100 & 100 & 300 & 100 & 100 & 100 & 300 & 100 & 100 & 100 & 300 \\
\hline
\end{tabular}


Apêndice 5 - Parâmetros fitossociológicos de espécies arbóreo-arbustivas na Área 2, em Cerrado sentido restrito, em Planaltina (DF), em seis ocasiões do monitoramento, em ordem do IVI do ano de 1990, onde: DR= Densidade relativa (\%); FR= Frequência relativa (\%) ; Do= Dominância Relativa (\%); IVI=Índice de valor de Importância (\%). Obs.: área protegida da ação do fogo de 1988 a julho de 1994 , e de 1995 a 2012; em 1994, o levantamento dos dados foi feito antes do fogo acidental que atingiu as duas áreas em agosto.

\begin{tabular}{|c|c|c|c|c|c|c|c|c|c|c|c|c|c|c|c|c|c|c|c|c|c|c|c|c|}
\hline \multirow[t]{2}{*}{ Espécies } & \multicolumn{4}{|c|}{1990} & \multicolumn{4}{|c|}{1991} & \multicolumn{4}{|c|}{1992} & \multicolumn{4}{|c|}{1993} & \multicolumn{4}{|c|}{1994} & \multicolumn{4}{|c|}{2012} \\
\hline & DR & FR & Do & IVI & DR & FR & Do & IVI & DR & FR & Do & IVI & DR & FR & Do & IVI & DR & FR & Do & IVI & DR & FR & Do & IVI \\
\hline $\begin{array}{l}\text { Dalbergia } \\
\text { miscolobium }\end{array}$ & 8,9 & 4,8 & 13,6 & 27,3 & 9,6 & 4,8 & 14,3 & 28,7 & 9,8 & 4,8 & 13,5 & 28,1 & 9,0 & 4,8 & 13,2 & 27,0 & 9,0 & 4,7 & 12,8 & 26,5 & 6,5 & 4,0 & 11,4 & 21,8 \\
\hline $\begin{array}{l}\text { Myrsine } \\
\text { guianensis }\end{array}$ & 15,5 & 5,3 & 4,3 & 25,1 & 16,6 & 5,3 & 4,6 & 26,5 & 17,7 & 5,3 & 5,2 & 28,2 & 18,9 & 5,0 & 6,7 & 30,6 & 19,0 & 5,0 & 6,1 & 30,1 & 28,9 & 4,5 & 20,9 & 54,2 \\
\hline Guapira noxia & 5,0 & 4,3 & 10,7 & 20,0 & 5,2 & 4,5 & 10,3 & 20,0 & 5,2 & 4,5 & 9,8 & 19,5 & 4,9 & 4,3 & 9,7 & 18,9 & 4,9 & 4,2 & 9,5 & 18,7 & 2,2 & 3,1 & 5,7 & 11,0 \\
\hline $\begin{array}{l}\text { Styrax } \\
\text { ferrugineus }\end{array}$ & 5,4 & 5,1 & 7,4 & 17,8 & 5,1 & 4,8 & 6,6 & 16,5 & 5,2 & 4,8 & 6,7 & 16,7 & 5,3 & 4,5 & 7,1 & 16,9 & 5,1 & 4,5 & 7,7 & 17,3 & 2,0 & 3,1 & 3,6 & 8,8 \\
\hline $\begin{array}{l}\text { Ouratea } \\
\text { hexasperma }\end{array}$ & 4,6 & 4,5 & 7,6 & 16,7 & 3,9 & 4,3 & 7,2 & 15,4 & 3,7 & 4,3 & 6,9 & 14,9 & 3,4 & 4,0 & 6,6 & 14,0 & 3,3 & 4,0 & 6,3 & 13,5 & 2,2 & 3,1 & 5,5 & 10,8 \\
\hline $\begin{array}{l}\text { Vellozia } \\
\text { squamata }\end{array}$ & 2,3 & 2,4 & 10,7 & 15,4 & 2,0 & 2,7 & 10,8 & 15,5 & 2,0 & 2,7 & 11,3 & 15,9 & 1,8 & 2,5 & 9,6 & 13,9 & 1,7 & 2,5 & 10,4 & 14,7 & 0,3 & 0,7 & 2,9 & 3,8 \\
\hline $\begin{array}{l}\text { Guapira } \\
\text { graciliflora }\end{array}$ & 5,5 & 4,5 & 1,7 & 11,7 & 4,2 & 4,5 & 1,2 & 9,9 & 3,8 & 4,3 & 1,4 & 9,5 & 4,0 & 4,3 & 1,8 & 10,1 & 4,0 & 4,2 & 1,7 & 10,0 & 4,6 & 4,0 & 1,9 & 10,6 \\
\hline $\begin{array}{l}\text { Byrsonima } \\
\text { verbascifolia }\end{array}$ & 2,7 & 3,7 & 4,7 & 11,1 & 2,7 & 3,7 & 4,8 & 11,2 & 2,7 & 3,7 & 4,5 & 11,0 & 2,6 & 3,8 & 4,4 & 10,7 & 2,5 & 3,7 & 4,3 & 10,5 & 0,7 & 1,6 & 1,2 & 3,4 \\
\hline $\begin{array}{l}\text { Aegiphila } \\
\text { verticillata }\end{array}$ & 3,1 & 4,0 & 1,0 & 8,1 & 3,2 & 4,3 & 1,1 & 8,5 & 2,8 & 4,3 & 1,1 & 8,2 & 2,6 & 4,0 & 1,1 & 7,7 & 2,7 & 3,7 & 1,0 & 7,4 & & & & \\
\hline Neea theifera & 3,2 & 3,2 & 1,0 & 7,4 & 4,2 & 3,7 & 1,5 & 9,4 & 4,3 & 4,0 & 1,5 & 9,8 & 4,2 & 4,0 & 1,9 & 10,2 & 4,2 & 4,0 & 1,7 & 9,9 & 0,2 & 0,5 & 0,1 & 0,7 \\
\hline $\begin{array}{l}\text { Kielmeyera } \\
\text { coriacea }\end{array}$ & 2,8 & 2,9 & 1,6 & 7,3 & 3,7 & 3,7 & 1,9 & 9,3 & 3,6 & 3,7 & 1,9 & 9,2 & 3,8 & 3,5 & 2,1 & 9,4 & 3,5 & 3,5 & 1,8 & 8,8 & 2,2 & 2,7 & 0,9 & 5,8 \\
\hline $\begin{array}{l}\text { Aspidosperma } \\
\text { macrocarpum }\end{array}$ & 3,2 & 2,4 & 1,1 & 6,7 & 3,8 & 2,7 & 1,0 & 7,5 & 3,8 & 2,7 & 1,2 & 7,7 & 3,8 & 2,8 & 1,3 & 7,9 & 3,7 & 2,7 & 1,3 & 7,7 & 3,7 & 2,7 & 2,6 & 9,0 \\
\hline $\begin{array}{l}\text { Leptolobium } \\
\text { dasycarpum }\end{array}$ & 2,4 & 2,9 & 1,3 & 6,7 & 2,4 & 2,9 & 1,4 & 6,7 & 2,4 & 2,9 & 1,5 & 6,8 & 2,3 & 2,8 & 1,4 & 6,5 & 2,5 & 3,2 & 1,3 & 7,0 & 2,2 & 2,7 & 1,3 & 6,2 \\
\hline $\begin{array}{l}\text { Dimorphandra } \\
\text { mollis }\end{array}$ & 1,7 & 2,9 & 2,1 & 6,6 & 2,2 & 3,2 & 2,0 & 7,4 & 1,9 & 2,9 & 2,1 & 6,9 & 1,7 & 2,8 & 2,1 & 6,5 & 1,9 & 3,0 & 2,2 & 7,0 & 0,8 & 1,8 & 1,5 & 4,1 \\
\hline $\begin{array}{l}\text { Connarus } \\
\text { suberosus }\end{array}$ & 2,6 & 2,1 & 1,8 & 6,5 & 2,8 & 2,4 & 1,7 & 6,9 & 2,8 & 2,4 & 1,7 & 6,9 & 2,3 & 2,3 & 1,5 & 6,1 & 2,3 & 2,2 & 1,5 & 6,0 & 0,9 & 1,1 & 0,8 & 2,8 \\
\hline $\begin{array}{l}\text { Aspidosperma } \\
\text { tomentosum }\end{array}$ & 2,0 & 2,7 & 1,6 & 6,3 & 2,2 & 2,7 & 1,6 & 6,4 & 2,1 & 2,7 & 1,5 & 6,3 & 2,1 & 2,8 & 1,6 & 6,5 & 2,3 & 2,7 & 1,5 & 6,5 & 2,6 & 3,6 & 2,2 & 8,3 \\
\hline $\begin{array}{l}\text { Hymenaea } \\
\text { stigonocarpa }\end{array}$ & 1,4 & 1,9 & 2,9 & 6,2 & 1,7 & 1,9 & 2,9 & 6,4 & 1,6 & 1,9 & 2,8 & 6,3 & 1,3 & 1,8 & 2,6 & 5,7 & 1,4 & 1,7 & 2,6 & 5,7 & 1,1 & 1,6 & 1,4 & 4,0 \\
\hline $\begin{array}{l}\text { Handroanthus } \\
\text { ochraceus }\end{array}$ & 2,0 & 1,9 & 1,5 & 5,4 & 2,2 & 2,4 & 1,4 & 5,9 & 2,4 & 2,4 & 1,4 & 6,2 & 2,5 & 2,5 & 1,6 & 6,6 & 2,4 & 2,5 & 1,4 & 6,3 & 0,5 & 1,3 & 0,5 & 2,4 \\
\hline Syagrus flexиosa & 1,4 & 1,9 & 1,6 & 4,9 & 2,0 & 2,7 & 3,0 & 7,7 & 2,2 & 3,2 & 2,5 & 7,9 & 2,1 & 3,0 & 2,4 & 7,6 & 2,1 & 3,0 & 3,7 & 8,7 & 0,5 & 1,1 & 0,5 & 2,1 \\
\hline $\begin{array}{l}\text { Roupala } \\
\text { montana }\end{array}$ & 2,0 & 2,1 & 0,6 & 4,8 & 2,5 & 2,7 & 0,8 & 6,0 & 2,5 & 2,7 & 0,9 & 6,0 & 2,6 & 2,8 & 1,2 & 6,5 & 2,5 & 2,7 & 1,1 & 6,4 & 2,9 & 3,4 & 4,7 & 11,0 \\
\hline
\end{tabular}




\begin{tabular}{|c|c|c|c|c|c|c|c|c|c|c|c|c|c|c|c|c|c|c|c|c|c|c|c|c|}
\hline \multirow[t]{2}{*}{ Espécies } & \multicolumn{4}{|c|}{1990} & \multicolumn{4}{|c|}{1991} & \multicolumn{4}{|c|}{1992} & \multicolumn{4}{|c|}{1993} & \multicolumn{4}{|c|}{1994} & \multicolumn{4}{|c|}{2012} \\
\hline & DR & FR & Do & IVI & DR & FR & Do & IVI & DR & FR & Do & IVI & DR & FR & Do & IVI & DR & FR & Do & IVI & DR & FR & Do & IVI \\
\hline $\begin{array}{l}\text { Erythroxylum } \\
\text { suberosum }\end{array}$ & 1,3 & 1,9 & 1,1 & 4,3 & 2,0 & 3,5 & 1,7 & 7,2 & 2,0 & 3,5 & 1,5 & 7,0 & 1,8 & 3,0 & 1,5 & 6,4 & 1,7 & 3,0 & 1,5 & 6,2 & 0,7 & 1,6 & 0,7 & 2,9 \\
\hline $\begin{array}{l}\text { Piptocarpha } \\
\text { rotundifolia }\end{array}$ & 1,2 & 1,3 & 1,7 & 4,2 & 1,1 & 1,3 & 1,0 & 3,5 & 1,1 & 1,3 & 1,0 & 3,4 & 1,0 & 1,3 & 1,1 & 3,4 & 1,0 & 1,2 & 0,9 & 3,1 & 1,1 & 1,6 & 1,9 & 4,6 \\
\hline $\begin{array}{l}\text { Stryphnodendro } \\
n \text { adstringens }\end{array}$ & 0,9 & 1,6 & 1,5 & 4,0 & 0,9 & 1,6 & 1,6 & 4,1 & 0,7 & 1,6 & 1,5 & 3,9 & 0,7 & 1,5 & 1,3 & 3,5 & 0,8 & 1,5 & 1,5 & 3,8 & 1,0 & 1,6 & 2,3 & 4,8 \\
\hline $\begin{array}{l}\text { Bauhinia } \\
\text { dumosa }\end{array}$ & 1,9 & 1,9 & 0,1 & 3,9 & & & & & & & & & & & & & & & & & 2,2 & 2,5 & 0,1 & 4,8 \\
\hline $\begin{array}{l}\text { Caryocar } \\
\text { brasiliense }\end{array}$ & 0,6 & 1,1 & 2,1 & 3,9 & 0,6 & 1,1 & 2,6 & 4,3 & 0,6 & 1,1 & 2,6 & 4,3 & 0,6 & 1,0 & 2,2 & 3,7 & 0,5 & 1,0 & 2,2 & 3,7 & 0,8 & 1,6 & 3,2 & 5,6 \\
\hline Protium ovatum & 1,7 & 1,9 & 0,3 & 3,8 & 0,8 & 0,5 & 0,1 & 1,4 & 0,9 & 0,8 & 0,1 & 1,8 & 1,0 & 1,0 & 0,2 & 2,2 & 1,0 & 1,0 & 0,1 & 2,1 & 3,9 & 3,8 & 0,6 & 8,2 \\
\hline $\begin{array}{l}\text { Psidium } \\
\text { laruotteanum }\end{array}$ & 1,0 & 1,6 & 1,1 & 3,7 & 1,0 & 1,9 & 0,6 & 3,4 & 1,0 & 1,9 & 0,9 & 3,8 & 1,0 & 2,0 & 0,7 & 3,8 & 1,0 & 2,0 & 0,7 & 3,7 & 0,4 & 1,1 & 0,6 & 2,1 \\
\hline $\begin{array}{l}\text { Palicourea } \\
\text { rigida }\end{array}$ & 1,0 & 1,9 & 0,6 & 3,5 & 1,7 & 2,9 & 0,9 & 5,5 & 1,6 & 2,9 & 1,0 & 5,5 & 2,3 & 3,5 & 1,5 & 7,4 & 2,3 & 3,5 & 1,6 & 7,3 & 2,4 & 3,4 & 3,0 & 8,8 \\
\hline $\begin{array}{l}\text { Tachigali } \\
\text { subvelutina }\end{array}$ & 0,6 & 1,3 & 1,3 & 3,3 & 0,6 & 1,3 & 1,6 & 3,5 & 0,6 & 1,3 & 1,7 & 3,7 & 0,7 & 1,3 & 2,0 & 3,9 & 0,7 & 1,2 & 2,2 & 4,1 & 0,6 & 1,3 & 4,7 & 6,7 \\
\hline $\begin{array}{l}\text { Eremanthus } \\
\text { goyazensis }\end{array}$ & 1,0 & 1,9 & 0,2 & 3,1 & 0,9 & 1,9 & 0,2 & 3,0 & 1,1 & 2,1 & 0,3 & 3,6 & 1,0 & 2,0 & 0,4 & 3,4 & 1,1 & 2,2 & 0,3 & 3,7 & 0,3 & 0,7 & 0,1 & 1,1 \\
\hline $\begin{array}{l}\text { Mimosa } \\
\text { claussenii }\end{array}$ & 0,9 & 1,3 & 0,7 & 2,9 & 0,3 & 0,5 & 0,2 & 0,9 & 0,4 & 0,5 & 0,2 & 1,1 & 0,3 & 0,3 & 0,2 & 0,8 & 0,3 & 0,5 & 0,1 & 1,0 & 1,2 & 1,6 & 0,8 & 3,6 \\
\hline $\begin{array}{l}\text { Erythroxylum } \\
\text { tortuosum }\end{array}$ & 0,6 & 1,3 & 0,9 & 2,9 & & & & & & & & & & & & & & & & & & & & \\
\hline $\begin{array}{l}\text { Annona } \\
\text { monticola }\end{array}$ & 1,0 & 1,6 & 0,1 & 2,7 & 0,4 & 0,8 & 0,0 & 1,2 & 0,1 & 0,3 & 0,0 & 0,4 & 0,5 & 1,0 & 0,1 & 1,5 & 0,4 & 1,0 & 0,1 & 1,5 & 0,8 & 1,8 & 0,1 & 2,6 \\
\hline $\begin{array}{l}\text { Strychnos } \\
\text { pseudoquina }\end{array}$ & 0,5 & 0,5 & 1,6 & 2,6 & 0,8 & 0,8 & 2,4 & 4,0 & 0,9 & 0,8 & 2,3 & 3,9 & 0,8 & 0,8 & 2,2 & 3,7 & 0,8 & 0,8 & 2,1 & 3,6 & 0,7 & 0,9 & 2,1 & 3,7 \\
\hline $\begin{array}{l}\text { Chomelia } \\
\text { ribesioides }\end{array}$ & 0,9 & 1,6 & 0,1 & 2,6 & 0,8 & 1,3 & 0,1 & 2,2 & 0,4 & 0,8 & 0,1 & 1,2 & 0,9 & 1,3 & 0,1 & 2,3 & 0,9 & 1,2 & 0,1 & 2,2 & 0,2 & 0,5 & 0,0 & 0,6 \\
\hline $\begin{array}{l}\text { Machaerium } \\
\text { opacum }\end{array}$ & 0,6 & 1,1 & 0,8 & 2,5 & 0,5 & 0,8 & 0,7 & 2,0 & 0,5 & 0,8 & 0,7 & 2,0 & 0,3 & 0,5 & 0,7 & 1,5 & 0,4 & 0,8 & 0,7 & 1,9 & 0,7 & 1,1 & 0,8 & 2,6 \\
\hline $\begin{array}{l}\text { Vochysia } \\
\text { elliptica }\end{array}$ & 0,5 & 1,1 & 0,9 & 2,5 & 0,5 & 1,1 & 0,9 & 2,5 & 0,5 & 1,1 & 0,9 & 2,5 & 0,6 & 1,3 & 1,0 & 2,8 & 0,5 & 1,2 & 0,9 & 2,7 & 0,5 & 1,1 & 0,6 & 2,2 \\
\hline $\begin{array}{l}\text { Plenckia } \\
\text { populnea }\end{array}$ & 0,6 & 1,1 & 0,4 & 2,1 & 0,5 & 0,8 & 0,5 & 1,8 & 0,6 & 1,1 & 0,4 & 2,1 & 0,7 & 1,3 & 0,5 & 2,4 & 0,7 & 1,2 & 0,5 & 2,4 & 0,3 & 0,7 & 0,3 & 1,3 \\
\hline $\begin{array}{l}\text { Schefflera } \\
\text { macrocarpa }\end{array}$ & 0,5 & 0,8 & 0,8 & 2,1 & 0,4 & 0,8 & 0,7 & 1,9 & 0,4 & 0,8 & 0,8 & 2,0 & 0,3 & 0,8 & 0,3 & 1,4 & 0,3 & 0,8 & 0,9 & 2,0 & 1,8 & 2,9 & 1,8 & 6,5 \\
\hline $\begin{array}{l}\text { Erythroxylum } \\
\text { deciduum }\end{array}$ & 0,6 & 1,1 & 0,3 & 2,0 & 1,0 & 1,9 & 0,5 & 3,4 & 1,0 & 1,9 & 0,5 & 3,4 & 0,9 & 1,8 & 0,5 & 3,2 & 1,0 & 2,0 & 0,5 & 3,5 & 1,7 & 2,0 & 1,0 & 4,7 \\
\hline $\begin{array}{l}\text { Salvertia } \\
\text { convallariodora }\end{array}$ & 0,1 & 0,3 & 1,5 & 1,9 & 0,1 & 0,3 & 1,4 & 1,8 & 0,1 & 0,3 & 1,3 & 1,7 & 0,1 & 0,3 & 1,2 & 1,6 & 0,1 & 0,3 & 1,3 & 1,6 & 0,2 & 0,5 & 1,4 & 2,1 \\
\hline $\begin{array}{l}\text { Casearia } \\
\text { sylvestris }\end{array}$ & 0,5 & 1,1 & 0,2 & 1,8 & 0,5 & 1,1 & 0,2 & 1,7 & 0,5 & 1,1 & 0,2 & 1,7 & 0,5 & 1,0 & 0,1 & 1,6 & 0,4 & 1,0 & 0,1 & 1,6 & 0,1 & 0,2 & 0,0 & 0,3 \\
\hline Senna rugosa & 0,4 & 0,5 & 0,7 & 1,6 & & & & & & & & & & & & & & & & & & & & \\
\hline
\end{tabular}




\begin{tabular}{|c|c|c|c|c|c|c|c|c|c|c|c|c|c|c|c|c|c|c|c|c|c|c|c|c|}
\hline \multirow[t]{2}{*}{ Espécies } & \multicolumn{4}{|c|}{1990} & \multicolumn{4}{|c|}{1991} & \multicolumn{4}{|c|}{1992} & \multicolumn{4}{|c|}{1993} & \multicolumn{4}{|c|}{1994} & \multicolumn{4}{|c|}{2012} \\
\hline & DR & FR & Do & IVI & DR & FR & Do & IVI & DR & FR & Do & IVI & DR & FR & Do & IVI & DR & FR & Do & IVI & DR & FR & Do & IVI \\
\hline $\begin{array}{l}\text { Eriotheca } \\
\text { pubescens }\end{array}$ & 0,4 & 0,8 & 0,4 & 1,6 & 0,4 & 0,8 & 0,4 & 1,6 & 0,4 & 0,8 & 0,4 & 1,5 & 0,3 & 0,8 & 0,4 & 1,5 & 0,3 & 0,8 & 0,4 & 1,5 & 0,3 & 0,7 & 0,6 & 1,5 \\
\hline $\begin{array}{l}\text { Zeyheria } \\
\text { montana }\end{array}$ & 0,6 & 0,8 & 0,1 & 1,5 & 0,6 & 0,8 & 0,1 & 1,5 & 0,6 & 0,8 & 0,1 & 1,5 & 0,6 & 0,8 & 0,1 & 1,4 & 0,5 & 0,8 & 0,1 & 1,4 & 0,3 & 0,9 & 0,1 & 1,3 \\
\hline $\begin{array}{l}\text { Pouteria } \\
\text { ramiflora }\end{array}$ & 0,4 & 0,3 & 0,6 & 1,2 & 0,4 & 0,3 & 0,6 & 1,2 & 0,4 & 0,3 & 0,5 & 1,2 & 0,3 & 0,3 & 0,5 & 1,1 & 0,3 & 0,3 & 0,5 & 1,1 & 0,2 & 0,5 & 0,2 & 0,8 \\
\hline $\begin{array}{l}\text { Diospyros } \\
\text { hispida }\end{array}$ & 0,4 & 0,5 & 0,2 & 1,1 & 0,4 & 0,5 & 0,2 & 1,1 & 0,4 & 0,5 & 0,2 & 1,1 & 0,5 & 0,8 & 0,2 & 1,4 & 0,5 & 0,8 & 0,3 & 1,6 & 0,3 & 0,7 & 0,1 & 1,0 \\
\hline Butia leiospatha & 0,1 & 0,3 & 0,6 & 1,0 & 0,1 & 0,3 & 0,4 & 0,8 & 0,1 & 0,3 & 0,5 & 0,9 & 0,1 & 0,3 & 0,5 & 0,9 & & & & & & & & \\
\hline $\begin{array}{l}\text { Tocoyena } \\
\text { formosa }\end{array}$ & 0,3 & 0,5 & 0,1 & 0,9 & 0,1 & 0,3 & 0,0 & 0,4 & & & & & 0,2 & 0,5 & 0,0 & 0,8 & 0,3 & 0,5 & 0,1 & 0,9 & 0,1 & 0,2 & 0,0 & 0,3 \\
\hline Andira humilis & 0,3 & 0,3 & 0,1 & 0,7 & 0,3 & 0,3 & 0,1 & 0,6 & 0,3 & 0,3 & 0,1 & 0,7 & 0,2 & 0,3 & 0,2 & 0,6 & 0,2 & 0,3 & 0,1 & 0,6 & & & & \\
\hline $\begin{array}{l}\text { Byrsonima } \\
\text { coccolobifolia }\end{array}$ & 0,1 & 0,3 & 0,2 & 0,6 & 0,3 & 0,5 & 0,2 & 1,0 & 0,4 & 0,8 & 0,2 & 1,4 & 0,5 & 0,8 & 0,2 & 1,4 & 0,4 & 0,8 & 0,2 & 1,4 & 0,8 & 1,3 & 0,4 & 2,5 \\
\hline $\begin{array}{l}\text { Plathymenia } \\
\text { reticulata }\end{array}$ & 0,1 & 0,3 & 0,1 & 0,4 & 0,1 & 0,3 & 0,1 & 0,5 & 0,1 & 0,3 & 0,0 & 0,4 & 0,1 & 0,3 & 0,1 & 0,4 & 0,1 & 0,3 & 0,0 & 0,4 & & & & \\
\hline $\begin{array}{l}\text { Annona } \\
\text { tomentosa }\end{array}$ & 0,1 & 0,3 & 0,0 & 0,4 & & & & & & & & & & & & & & & & & 2,9 & 4,0 & 0,5 & 7,4 \\
\hline $\begin{array}{l}\text { Brosimum } \\
\text { gaudichaudii }\end{array}$ & 0,1 & 0,3 & 0,0 & 0,4 & & & & & & & & & & & & & & & & & 0,1 & 0,2 & 0,0 & 0,3 \\
\hline $\begin{array}{l}\text { Byrsonima } \\
\text { basiloba }\end{array}$ & 0,1 & 0,3 & 0,0 & 0,4 & & & & & & & & & & & & & & & & & & & & \\
\hline Davilla elliptica & 0,1 & 0,3 & 0,0 & 0,4 & & & & & & & & & & & & & & & & & & & & \\
\hline $\begin{array}{l}\text { Andira } \\
\text { vermifuga }\end{array}$ & & & & & & & & & & & & & & & & & & & & & 0,1 & 0,2 & 0,1 & 0,4 \\
\hline $\begin{array}{l}\text { Annona } \\
\text { crassiflora }\end{array}$ & & & & & & & & & & & & & & & & & & & & & 0,2 & 0,5 & 0,1 & 0,7 \\
\hline Bauhinia rufa & & & & & & & & & & & & & & & & & & & & & 0,2 & 0,5 & 0,0 & 0,6 \\
\hline Cordiera sessilis & & & & & & & & & & & & & & & & & & & & & 0,1 & 0,2 & 0,0 & 0,3 \\
\hline $\begin{array}{l}\text { Cybianthus } \\
\text { gardneri }\end{array}$ & & & & & & & & & & & & & & & & & & & & & 0,1 & 0,2 & 0,0 & 0,3 \\
\hline $\begin{array}{l}\text { Enterolobium } \\
\text { gummiferum }\end{array}$ & & & & & & & & & & & & & & & & & & & & & 0,1 & 0,2 & 0,0 & 0,3 \\
\hline $\begin{array}{l}\text { Heteropterys } \\
\text { byrsonimifolia }\end{array}$ & & & & & & & & & & & & & & & & & & & & & 0,3 & 0,7 & 0,2 & 1,1 \\
\hline $\begin{array}{l}\text { Maprounea } \\
\text { guianensis }\end{array}$ & & & & & & & & & & & & & & & & & & & & & 0,1 & 0,2 & 0,0 & 0,3 \\
\hline $\begin{array}{l}\text { Miconia } \\
\text { albicans }\end{array}$ & & & & & & & & & & & & & & & & & & & & & 3,6 & 3,8 & 0,7 & 8,1 \\
\hline $\begin{array}{l}\text { Miconia } \\
\text { burchellii }\end{array}$ & & & & & & & & & & & & & & & & & & & & & 1,5 & 2,5 & 0,7 & 4,6 \\
\hline Miconia fallax & & & & & & & & & & & & & & & & & & & & & 2,5 & 2,9 & 0,1 & 5,5 \\
\hline
\end{tabular}




\begin{tabular}{|c|c|c|c|c|c|c|c|c|c|c|c|c|c|c|c|c|c|c|c|c|c|c|c|c|}
\hline \multirow[t]{2}{*}{ Espécies } & \multicolumn{4}{|c|}{1990} & \multicolumn{4}{|c|}{1991} & \multicolumn{4}{|c|}{1992} & \multicolumn{4}{|c|}{1993} & \multicolumn{4}{|c|}{1994} & \multicolumn{4}{|c|}{2012} \\
\hline & DR & FR & Do & IVI & DR & FR & Do & IVI & DR & FR & Do & IVI & DR & FR & Do & IVI & DR & FR & Do & IVI & DR & FR & Do & IVI \\
\hline $\begin{array}{l}\text { Miconia } \\
\text { ferruginea }\end{array}$ & & & & & & & & & & & & & & & & & & & & & 0,1 & 0,2 & 0,0 & 0,4 \\
\hline $\mathrm{Ni}$-lauraceae & & & & & & & & & & & & & & & & & & & & & 0,1 & 0,2 & 0,2 & 0,5 \\
\hline $\begin{array}{l}\text { Qualea } \\
\text { grandiflora }\end{array}$ & & & & & & & & & & & & & & & & & & & & & 0,1 & 0,2 & 0,2 & 0,5 \\
\hline & & & & & & & & & & & & & 0,1 & 0,3 & 0,0 & 0,4 & 0,1 & 0,3 & 0,0 & 0,4 & 0,2 & 0,5 & 0,0 & 0,7 \\
\hline $\begin{array}{l}\text { Syagrus } \\
\text { oleracea }\end{array}$ & & & & & 0,1 & 0,3 & 0,3 & 0,7 & 0,1 & 0,3 & 0,5 & 0,9 & 0,1 & 0,3 & 0,5 & 0,9 & 0,1 & 0,3 & 0,5 & 0,9 & & & & \\
\hline Total Geral & 100 & 100 & 100 & 300 & 100 & 100 & 100 & 300 & 100 & 100 & 100 & 300 & 100 & 100 & 100 & 300 & 100 & 100 & 100 & 300 & 100 & 100 & 100 & 300 \\
\hline
\end{tabular}


Apêndice 6 - Frequência relativa (\%) das espécies, de acordo com a família e hábito, do estrato herbáceo em duas áreas de um Cerrado sentido restrito em Planaltina (DF), no período de 1988 a 2012, sendo: Área 1 = com queimadas bienais em 1988, 1990 e 1992 , e proteção do fogo de 1995 a 2012; Área 2= com proteção contra o fogo de 1988 a julho de 1994, e de 1995 a 2012; arvo=árvore; arbu=arbusto; suba=subarbusto; trep=trepadeira. Obs.: o levantamento dos dados, em 1994, foi realizado antes do fogo acidental que atingiu as duas áreas em agosto.

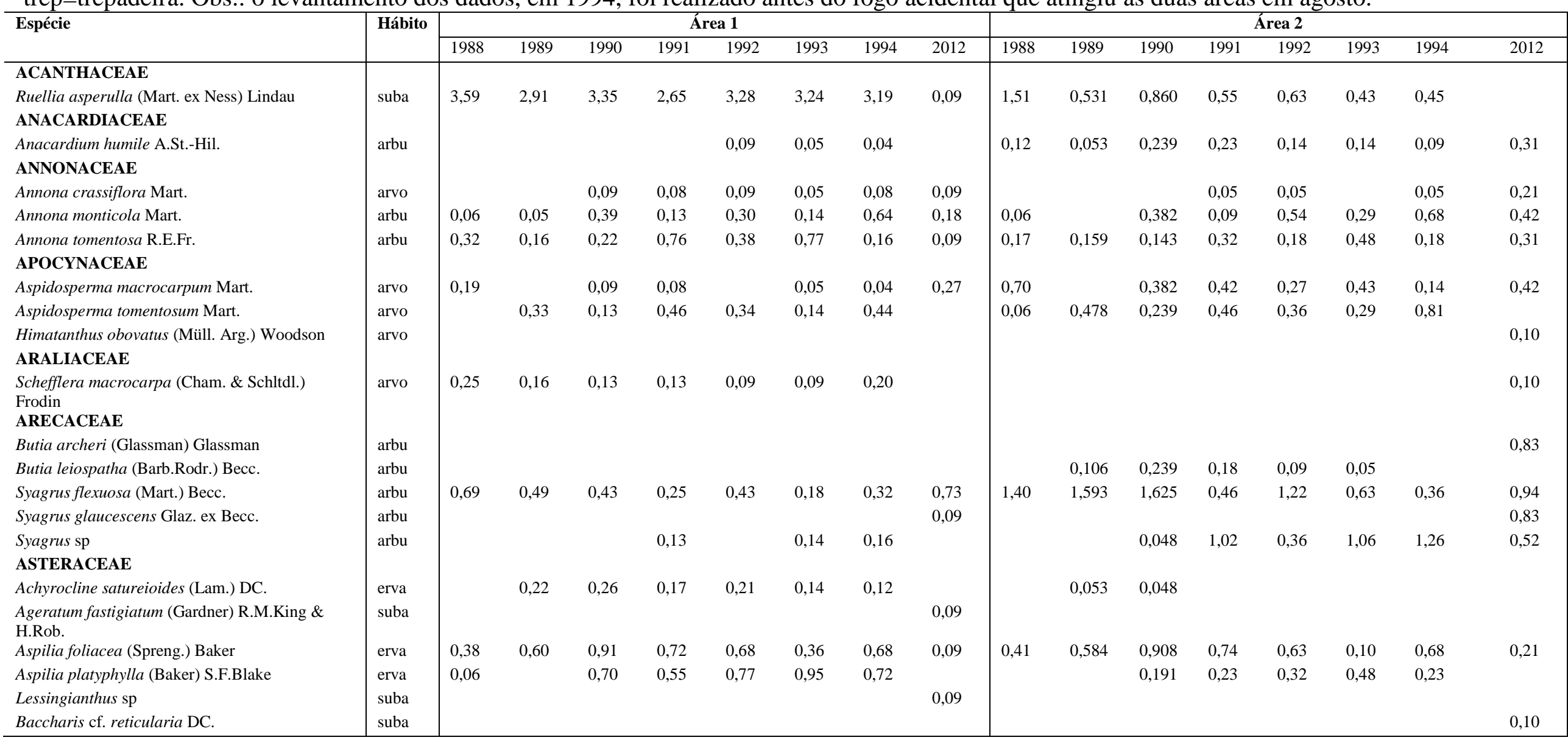




\begin{tabular}{|c|c|c|c|c|c|c|c|c|c|c|c|c|c|c|c|c|c|}
\hline \multirow[t]{2}{*}{ Espécie } & \multirow[t]{2}{*}{ Hábito } & \multicolumn{8}{|c|}{ Área 1} & \multicolumn{8}{|c|}{ Área 2} \\
\hline & & 1988 & 1989 & 1990 & 1991 & 1992 & 1993 & 1994 & 2012 & 1988 & 1989 & 1990 & 1991 & 1992 & 1993 & 1994 & 2012 \\
\hline Bacharis subdentata DC. & suba & & 0,27 & 0,04 & & & & & & & 0,584 & & 0,05 & 0,05 & & 0,09 & \\
\hline Bidens graveolens Mart. & suba & & & & & & 0,05 & 0,04 & & & & & & 0,05 & 0,10 & & \\
\hline Echinocoryne holosericea (Mart. ex DC.) H.Rob. & suba & & & & & & & & 0,09 & & & & & & & & \\
\hline Eremanthus goyazensis (Gardner) Sch.Bip. & arbu & 0,38 & 0,05 & 0,30 & 0,29 & 0,17 & 0,09 & 0,08 & 0,09 & 0,23 & 0,319 & 0,335 & 0,42 & 0,41 & 0,53 & 0,36 & 0,31 \\
\hline Eupatorium sp & suba & & 0,05 & 0,26 & 0,34 & 0,09 & 0,05 & 0,12 & & & & 0,287 & 0,14 & 0,05 & 0,05 & 0,09 & \\
\hline Ichthyothere latifolia Baker & suba & & 0,16 & 0,52 & 0,08 & 0,30 & 0,54 & 0,44 & & & 0,053 & & & 0,14 & & 0,05 & \\
\hline Lessingianthus lanuginosus Dematt. & suba & & & & & & & & 0,09 & & & & & & & & \\
\hline Lessingianthus coriaceus (Less.) H.Rob. & suba & 0,06 & & 0,09 & & & 0,05 & & & & & & & & 0,05 & 0,14 & \\
\hline $\begin{array}{l}\text { Piptocarpha rotundifolia (Less.) Baker } \\
\text { BIGNONIACEAE }\end{array}$ & arvo & 0,44 & 0,44 & 0,43 & 0,38 & 0,34 & 0,41 & 0,36 & 0,09 & 0,12 & 0,159 & 0,096 & 0,14 & 0,09 & 0,14 & 0,23 & 0,21 \\
\hline $\begin{array}{l}\text { Adenocalymma pedunculatum (Vell.) } \\
\text { L.G.Lohmann }\end{array}$ & suba & 0,57 & 0,27 & 0,83 & 0,08 & 0,77 & & 0,80 & 1,18 & 1,51 & 0,637 & 2,199 & 0,74 & 1,08 & 1,40 & 0,59 & 0,62 \\
\hline $\begin{array}{l}\text { Anemopaegma arvense (Vell.) Stellfeld ex de } \\
\text { Souza }\end{array}$ & suba & & 0,11 & & & & 0,05 & 0,28 & 0,09 & & 0,159 & & 0,37 & & & 0,36 & 0,31 \\
\hline Anemopaegma glaucum Mart. ex DC. & suba & 0,38 & 0,82 & 0,13 & 0,38 & 0,17 & 0,27 & 0,04 & 0,18 & 0,52 & 0,478 & 0,574 & 0,23 & 0,45 & 0,63 & & \\
\hline Fridericia platyphylla (Cham.) L.G.Lohmann & suba & 0,57 & 0,93 & 0,22 & 0,97 & 0,21 & 1,04 & & & 0,17 & 0,850 & 0,191 & 0,83 & 0,23 & 0,63 & & \\
\hline Cybistax antisyphilitica (Mart.) Mart. & arvo & & & & & & & & 0,09 & & & & & & & & \\
\hline Handroanthus ochraceus (Cham.) Mattos & arvo & 0,32 & 0,82 & 0,17 & 0,34 & 0,17 & 0,50 & 0,48 & 0,55 & 0,23 & 0,159 & 0,239 & 0,18 & 0,23 & 0,24 & 0,18 & 0,52 \\
\hline Jacaranda ulei Bureau \& K.Schum. & suba & & & 0,52 & & 0,30 & 0,72 & 0,76 & 0,46 & & & 0,143 & & 0,18 & 0,10 & 0,36 & 0,31 \\
\hline Zeyhera montana Mart. & arvo & 0,06 & 0,05 & 0,04 & 0,17 & 0,17 & 0,05 & 0,04 & & & 0,053 & & & & & & \\
\hline BROMELIACEAE & & & & & & & & & & & & & & & & & \\
\hline NI & erva & & & & & & & & & & & & & & & & 0,31 \\
\hline $\begin{array}{l}\text { Dyckia trichostachya Baker } \\
\text { BURSERACEAE }\end{array}$ & erva & & & & & & 0,05 & 0,16 & & 0,23 & 0,266 & 0,143 & 0,32 & 0,27 & 0,24 & 0,18 & 0,31 \\
\hline $\begin{array}{l}\text { Protium ovatum Engl. } \\
\text { CALLOPHYLLACEAE }\end{array}$ & arbu & 0,82 & 0,38 & 0,39 & 0,38 & 0,43 & 0,59 & 0,40 & 0,91 & 0,35 & 0,425 & 0,478 & 0,42 & 0,59 & 0,63 & 0,63 & 0,62 \\
\hline Kielmeyera abdita Saddi & suba & & & 0,04 & 0,08 & 0,09 & & 0,04 & & & & & & 0,05 & & 0,05 & \\
\hline Kielmeyera coriacea Mart. \& Zucc. & arvo & 0,19 & & 0,13 & 0,04 & 0,04 & 0,05 & 0,04 & 0,18 & & & 0,048 & 0,05 & 0,09 & 0,14 & 0,09 & \\
\hline Kielmeyera speciosa A.St.-Hil. & arvo & & & & & 0,04 & & 0,04 & 0,09 & & & & & & & & \\
\hline CARYOCARACEAE & & & & & & & & & & & & & & & & & \\
\hline $\begin{array}{l}\text { Caryocar brasiliense Cambess. } \\
\text { CELASTRACEAE }\end{array}$ & arvo & & 0,05 & 0,17 & 0,08 & 0,04 & 0,09 & 0,12 & & 0,12 & 0,159 & 0,143 & 0,14 & 0,14 & 0,10 & 0,14 & 0,10 \\
\hline $\begin{array}{l}\text { Peritassa campestris (Cambess.) A.C.Sm. } \\
\text { Plenckia populnea Reissek }\end{array}$ & $\begin{array}{c}\text { suba } \\
\text { arvo }\end{array}$ & & 0.49 & 0.35 & 0.17 & 0.26 & 0.18 & 0.24 & 0.09 & 0.23 & & 0.143 & 0.18 & 0.18 & 0.14 & 0.18 & 0,31 \\
\hline Salacia crassifolia (Mart. ex Schult.) G.Don & arbu & 0,25 & 0,38 & 0,30 & 0,25 & 0,21 & 0,32 & 0,32 & 0,82 & 0,41 & 0,319 & 0,765 & 0,65 & 0,54 & 0,77 & 0,45 & 0,42 \\
\hline CHRYSOBALANACEAE & & & & & & & & & & & & & & & & & \\
\hline Parinari obtusifolia Hook.f. & suba & & & & & 0.04 & 0.05 & & 0.09 & & & & & & & & \\
\hline
\end{tabular}




\begin{tabular}{|c|c|c|c|c|c|c|c|c|c|c|c|c|c|c|c|c|c|}
\hline \multirow[t]{2}{*}{ Espécie } & \multirow[t]{2}{*}{ Hábito } & \multicolumn{8}{|c|}{ Área 1} & \multicolumn{8}{|c|}{ Área 2} \\
\hline & & 1988 & 1989 & 1990 & 1991 & 1992 & 1993 & 1994 & 2012 & 1988 & 1989 & 1990 & 1991 & 1992 & 1993 & 1994 & 2012 \\
\hline COMBRETACEAE & & & & & & & & & & & & & & & & & \\
\hline $\begin{array}{l}\text { Terminalia fagifolia Mart. } \\
\text { CONNARACEAE }\end{array}$ & arvo & 0,06 & 0,05 & 0,09 & 0,08 & 0,09 & 0,05 & 0,08 & & & & & & & & & \\
\hline Connarus suberosus Planch. & arvo & 0,76 & 0,66 & 0,96 & 1,05 & 0,72 & 0,90 & 0,64 & 1,09 & 0,35 & 0,212 & 0,382 & 0,18 & 0,36 & 0,29 & 0,23 & 0,21 \\
\hline $\begin{array}{l}\text { Rourea chrysomalla Glaz. ex G.Schellenb. } \\
\text { CONVOLVULACEAE }\end{array}$ & suba & 0,13 & 0,33 & 0,35 & 0,42 & 0,34 & 0,50 & 0,28 & 0,36 & 0,17 & 0,425 & 0,574 & 0,28 & 0,23 & 0,58 & 0,45 & 0,21 \\
\hline Ipomoea procumbens Mart. ex Choisy & trep & & 1,26 & & 1,39 & 1,54 & 1,58 & 1,32 & & 0,06 & 0,637 & & 1,11 & 1,13 & 0,53 & 1,35 & \\
\hline $\begin{array}{l}\text { Merremia digitata (Spreng.) Hallier } \mathrm{f} . \\
\text { CUCURBITACEAE }\end{array}$ & trep & 4,85 & 5,99 & 5,35 & 5,14 & 4,14 & 2,48 & 2,95 & 0,27 & 3,72 & 4,886 & 4,493 & 4,57 & 4,38 & 2,65 & 3,83 & 0,42 \\
\hline $\begin{array}{l}\text { Cayaponia espelina (Silva Manso) Cogn. } \\
\text { CYPERACEAE }\end{array}$ & trep & & 0,11 & 0,04 & 0,42 & 0,26 & 0,05 & 0,40 & 0,09 & & 0,212 & 0,096 & 0,09 & 0,05 & 0,10 & 0,23 & \\
\hline Rhynchospora consanguinea (Kunth) Boeckeler & erva & 0,06 & 0,38 & 0,13 & 0,80 & 0,13 & 0,18 & & 0,36 & 0,23 & 0,319 & 0,239 & 0,23 & 0,23 & 0,14 & 0,05 & 0,21 \\
\hline Rhynchospora exaltata Kunth & erva & 0,32 & 0,55 & 1,30 & 0,29 & 0,55 & 1,17 & 1,40 & 3,01 & 0,81 & 0,637 & 0,765 & 0,55 & 0,68 & 1,01 & 0,95 & 2,71 \\
\hline $\begin{array}{l}\text { Rhynchospora globosa (Kunth) Roem. \& Schult. } \\
\text { DILLENIACEAE }\end{array}$ & erva & & & 0,39 & & 0,09 & 0,23 & 0,24 & 0,09 & & & & & 0,18 & 0,24 & 0,41 & 0,10 \\
\hline $\begin{array}{l}\text { Davilla elliptica } \text { A.St.-Hil. } \\
\text { EBENACEAE }\end{array}$ & arvo & 0,76 & 0,33 & 0,39 & 0,34 & 0,47 & 0,41 & 0,36 & 0,55 & 0,41 & 0,478 & 0,526 & 0,46 & 0,45 & 0,63 & 0,59 & 0,62 \\
\hline $\begin{array}{l}\text { Diospyros burchellii Hiern } \\
\text { ERYTHROXYLACEAE }\end{array}$ & arvo & 0,13 & 0,16 & 0,09 & 0,17 & 0,17 & 0,14 & 0,20 & & 0,06 & 0,106 & & 0,05 & 0,09 & 0,10 & 0,09 & \\
\hline Erythroxylum campestre A.St.-Hil. & arbu & 0,19 & 0,55 & 0,70 & 0,67 & 0,85 & 0,77 & 0,76 & 0,27 & 1,45 & 0,531 & 0,621 & 1,06 & 0,86 & 1,06 & 1,13 & 0,94 \\
\hline Erythroxylum deciduum A.St.-Hil. & arvo & 0,57 & 0,05 & 0,22 & 0,17 & 0,17 & 0,18 & 0,32 & 0,27 & 0,12 & 0,053 & 0,430 & 0,28 & 0,27 & 0,48 & 0,36 & 0,94 \\
\hline Erythroxylum suberosum A.St.-Hil. & arvo & & & & & 0,04 & 0,09 & & & & & & 0,28 & 0,54 & 0,58 & 0,36 & 0,31 \\
\hline $\begin{array}{l}\text { Erythroxylum tortuosum Mart. } \\
\text { EUPHORBIACEAE }\end{array}$ & arbu & & 0,05 & 0,04 & 0,04 & 0,04 & 0,05 & 0,12 & 0,18 & & 0,584 & 0,621 & 0,28 & 0,09 & 0,10 & 0,18 & 0,31 \\
\hline Croton campestris A.St.-Hil. & suba & 2,21 & 2,75 & 2,65 & 2,74 & 2,26 & 2,75 & 3,15 & 1,91 & 2,09 & 2,284 & 2,008 & 2,17 & 2,44 & 1,93 & 2,79 & 2,39 \\
\hline Croton goyazensis Müll.Arg. & suba & & & 0,09 & & 0,04 & 0,09 & 0,16 & & & & 0,096 & & 0,05 & 0,10 & 0,45 & \\
\hline Euphorbia potentilloides Boiss. & erva & 1,51 & 2,03 & 1,09 & 1,26 & 1,11 & 1,17 & 1,16 & 0,55 & 1,86 & 1,434 & 1,864 & 1,43 & 1,76 & 1,74 & 1,94 & 1,87 \\
\hline Manihot gracilis Pohl & suba & 0,25 & & & & & & & & & & & & & & & 0,10 \\
\hline Manihot violacea Pohl & suba & & & & & & & & 0,27 & & & & & & & & 0,21 \\
\hline Maprounea guianensis Aubl. & arvo & & & 0,04 & 0,04 & & 0,05 & 0,08 & 0,18 & & & & & & & & \\
\hline Sebastiania sp & suba & & & & & & & & & 0,06 & & & & & & & \\
\hline FABACEAE & & & & & & & & & & & & & & & & & \\
\hline Andira humilis Mart. ex Benth. & arbu & & & & & & & & & 0,17 & 0,797 & 0,860 & 0,46 & 1,26 & 0,63 & 0,90 & 1,46 \\
\hline Bauhinia dumosa Benth. & arbu & 2,96 & 3,02 & 3,00 & 2,65 & 2,39 & 2,48 & 2,91 & 0,91 & 1,51 & 1,593 & 1,673 & 1,66 & 1,44 & 1,40 & 1,71 & 0,73 \\
\hline Bauhinia rufa (Bong.) Steud. & arvo & & 0,11 & 0,09 & & 0,21 & 0,05 & 0,20 & 0,18 & 0,06 & 0,053 & 0,048 & 0,14 & 0,27 & 0,10 & 0,23 & 0,42 \\
\hline Calliandra dysantha Benth. & suba & 0,13 & & & & 0,26 & & & & & & & 0,05 & & & & \\
\hline Calliandra virgata Benth. & suba & 1,89 & 2,31 & 1,61 & 1,94 & 1,62 & 1,62 & 1,92 & 3,28 & 2,21 & 2,230 & 2,342 & 2,03 & 1,94 & 2,12 & 1,67 & 2,71 \\
\hline Centrosema bracteosum Benth. & trep & & 0,05 & 0,04 & & & 0,09 & 0,20 & 0,09 & 0,17 & 0,690 & 1,004 & 1,06 & 1,44 & 0,58 & 1,26 & 0,52 \\
\hline
\end{tabular}




\begin{tabular}{|c|c|c|c|c|c|c|c|c|c|c|c|c|c|c|c|c|c|}
\hline \multirow[t]{2}{*}{ Espécie } & \multirow[t]{2}{*}{ Hábito } & \multicolumn{8}{|c|}{ Área 1} & \multicolumn{8}{|c|}{ Área 2} \\
\hline & & 1988 & 1989 & 1990 & 1991 & 1992 & 1993 & 1994 & 2012 & 1988 & 1989 & 1990 & 1991 & 1992 & 1993 & 1994 & 2012 \\
\hline $\begin{array}{l}\text { Chamaecrista basifolia (Vogel) H.S.Irwin \& } \\
\text { Barneby }\end{array}$ & Erva & & & & & & & & 0,27 & & & & & & & & \\
\hline $\begin{array}{l}\text { Chamaecrista orbiculata (Benth.) H.S.Irwin \& } \\
\text { Barneby }\end{array}$ & suba & 0,13 & 0,22 & & & 0,04 & & & 0,18 & 0,06 & & & & & & & \\
\hline Crotalaria sp & suba & & & 0,09 & & 0,04 & & 0,08 & & & & & 0,05 & 0,05 & 0,10 & & \\
\hline Dalbergia miscolobium Benth. & arvo & 0,63 & 0,49 & 0,26 & 0,46 & 0,55 & 0,54 & 0,36 & 0,36 & 0,93 & 1,062 & 1,482 & 1,52 & 1,49 & 1,40 & 1,44 & 0,62 \\
\hline Dimorphandra mollis Benth. & arvo & & & & 0,04 & 0,04 & 0,05 & & 0,27 & 0,17 & 0,053 & 0,191 & 0,14 & 0,18 & 0,14 & 0,14 & 0,10 \\
\hline Eriosema defoliatum Benth. & suba & & 0,16 & 0,22 & 0,08 & 0,26 & 0,14 & 0,04 & & 0,06 & 0,478 & 0,430 & & 0,45 & 0,53 & 0,05 & 0,42 \\
\hline Galactia neesii DC. & erva & 0,44 & 0,99 & 1,00 & 1,60 & 1,49 & 0,63 & 0,96 & 0,73 & 0,81 & 0,743 & 0,813 & 1,89 & 0,95 & 0,68 & 0,54 & 0,62 \\
\hline Hymenaea stigonocarpa Mart. ex Hayne & arvo & 0,06 & 0,05 & 0,04 & 0,08 & 0,04 & 0,05 & 0,08 & & 0,17 & 0,106 & 0,382 & 0,42 & 0,41 & 0,24 & 0,27 & \\
\hline Leptolobium dasycarpum Vogel & arvo & 0,06 & 0,38 & 0,17 & 0,25 & 0,17 & 0,23 & 0,28 & 0,27 & & 0,106 & 0,096 & 0,18 & 0,27 & 0,19 & 0,23 & 0,52 \\
\hline Lupinus velutinus Benth. & suba & & & 0,04 & & 0,04 & & 0,04 & & & & & 0,05 & 0,05 & 0,05 & 0,09 & \\
\hline Machaerium opacum Vogel & arvo & 0,19 & 0,22 & 0,13 & 0,34 & 0,30 & 0,27 & 0,20 & 0,18 & 0,12 & & 0,048 & & 0,09 & 0,10 & 0,05 & 0,10 \\
\hline Mimosa claussenii Benth. & arvo & 0,38 & 0,27 & 0,22 & 0,29 & 0,38 & 0,23 & 0,24 & & 0,29 & 0,212 & 0,143 & 0,32 & 0,05 & 0,05 & 0,27 & 0,21 \\
\hline Mimosa radula Benth. & suba & & 0,44 & 0,17 & 0,21 & 0,17 & 0,09 & 0,20 & 0,27 & & & 0,143 & 0,23 & 0,18 & & 0,32 & 0,10 \\
\hline Mimosa sp & erva & & 0,77 & 0,78 & 0,55 & 0,60 & 1,13 & 0,64 & 0,27 & 0,12 & 0,478 & 0,430 & 0,42 & 0,86 & 0,72 & 0,68 & 0,31 \\
\hline Periandra mediterranea (Vell.) Taub. & suba & 0,25 & 0,27 & 0,22 & 0,17 & 0,13 & 0,41 & 0,28 & 0,36 & 0,29 & 0,743 & 0,191 & 0,09 & & 0,14 & 0,54 & 0,10 \\
\hline Plathymenia reticulata Benth. & arvo & & & & & & & & & 0,06 & 0,053 & 0,048 & & 0,05 & 0,05 & 0,05 & \\
\hline Tachigali subvelutina (Benth.) Oliveira-Filho & arvo & 0,13 & 0,22 & 0,13 & 0,34 & 0,30 & 0,18 & 0,36 & 0,09 & 0,17 & 0,159 & 0,191 & 0,28 & 0,23 & 0,14 & 0,23 & 0,21 \\
\hline Senna rugosa (G.Don) H.S.Irwin \& Barneby & arbu & 0,13 & 0,22 & 0,13 & 0,13 & & 0,05 & 0,16 & & 0,41 & 0,212 & & 0,14 & 0,09 & 0,29 & 0,05 & 0,21 \\
\hline Stryphnodendron adstringens (Mart.) Coville & arvo & 0,25 & 0,16 & 0,04 & 0,13 & 0,09 & 0,05 & 0,08 & 0,09 & 0,23 & 0,106 & 0,239 & & 0,18 & 0,10 & 0,18 & 0,21 \\
\hline Stylosanthes sp & suba & & & & & & & & & & & & & & & 0,09 & \\
\hline Zornia sp & suba & & & & & & & 0,24 & & 0,06 & & & & & & 0,0900901 & \\
\hline GENTIANACEAE & & & & & & & & & & & & & & & & & \\
\hline Calolisianthus acutangulus (Mart.) Gilg & erva & & & & & & & 0,08 & & & & & & & & & \\
\hline $\begin{array}{l}\text { Deianira pallescens Cham. \& Schltdl. } \\
\text { IRIDACEAE }\end{array}$ & erva & & & & & & & & 0,09 & & & & & & & & \\
\hline Sisyrinchium vaginatum Spreng. & erva & 0,38 & 0,27 & 0,48 & 0,25 & 0,47 & 0,59 & 0,52 & 0,18 & 0,35 & 0,531 & 0,335 & 0,18 & 0,14 & 0,29 & 0,18 & 0,10 \\
\hline LAMIACEAE & & & & & & & & & & & & & & & & & \\
\hline Aegiphila verticillata Vell. & arvo & 0,06 & 0,33 & 0,35 & 0,34 & 0,26 & 0,45 & 0,28 & 0,18 & 0,06 & 0,106 & 0,287 & 0,05 & 0,09 & 0,24 & 0,50 & \\
\hline Amasonia campestris (Aubl.) Moldenke & suba & & & 0,04 & & & & & & & & 0,048 & & & & & \\
\hline Hypenia macrantha (A.St.-Hil. ex Benth.) Harley & suba & 1,70 & 0,88 & 0,65 & 0,63 & 0,51 & 0,86 & 0,76 & & 1,10 & 0,743 & 0,430 & 0,83 & 0,36 & 0,48 & 0,41 & 0,52 \\
\hline $\begin{array}{l}\text { Oocephalus lythroides (Pohl ex Benth.) Harley \& } \\
\text { J.F.B.Pastore }\end{array}$ & suba & & & 1,22 & & & 0,36 & 1,48 & 0,46 & & & 1,195 & 0,37 & & 0,19 & 1,76 & 0,62 \\
\hline Hyptis sp & suba & & & & 1,01 & 1,15 & 0,68 & 0,32 & 0,09 & & & & 0,74 & 1,17 & 1,69 & 0,36 & \\
\hline LAURACEAE & & & & & & & & & & & & & & & & & \\
\hline Cassytha filiformis $\mathrm{L}$. & trep & 0,13 & 0,11 & 0,35 & & 0,04 & 0,05 & & 0,46 & 0,23 & 0,053 & & & & 0,14 & & \\
\hline LOGANIACEAE & & & & & & & & & & & & & & & & & \\
\hline Strychnos pseudoquina A.St.-Hil. & arvo & & 0,05 & & 0,29 & 0,09 & & 0,04 & & & & & & & 0,05 & & \\
\hline
\end{tabular}




\begin{tabular}{|c|c|c|c|c|c|c|c|c|c|c|c|c|c|c|c|c|c|}
\hline \multirow[t]{2}{*}{ Espécie } & \multirow[t]{2}{*}{ Hábito } & \multicolumn{8}{|c|}{ Área 1} & \multicolumn{8}{|c|}{ Área 2} \\
\hline & & 1988 & 1989 & 1990 & 1991 & 1992 & 1993 & 1994 & 2012 & 1988 & 1989 & 1990 & 1991 & 1992 & 1993 & 1994 & 2012 \\
\hline \multicolumn{18}{|l|}{ LYTHRACEAE } \\
\hline Cuphea spermacoce A.St.-Hil. & suba & & & & & & & & & & & & & & & & 0,10 \\
\hline Diplusodon oblongus Pohl & suba & 2,71 & 1,81 & 2,48 & 1,69 & 2,05 & 1,58 & 1,48 & 2,19 & 3,43 & 2,868 & 2,629 & 2,26 & 2,08 & 1,83 & 1,58 & 3,54 \\
\hline \multicolumn{18}{|l|}{ MALPIGHIACEAE } \\
\hline Banisteriopsis sp1 & suba & & & & & & & & 0,46 & & & & & & & & 0,31 \\
\hline Banisteriopsis campestris (A.Juss.) Little & suba & 2,02 & 1,48 & 1,56 & 1,01 & 0,98 & 1,13 & 1,12 & & 0,58 & 0,425 & 0,908 & 0,69 & 0,77 & 0,77 & 0,90 & \\
\hline Banisteriopsis sp2 & suba & & & & & & & & 2,73 & & & & & & & & 1,98 \\
\hline Byrsonima basiloba A.Juss. & arbu & 0,06 & 0,05 & 0,09 & 0,13 & 0,13 & 0,09 & 0,08 & 0,09 & 0,06 & 0,053 & 0,143 & 0,05 & 0,05 & 0,05 & & 0,21 \\
\hline Byrsonima coccolobifolia Kunth & arvo & & & & & & & 0,28 & 0,09 & & & & 0,05 & 0,09 & & 0,23 & \\
\hline Byrsonima verbascifolia (L.) DC. & arvo & 0,25 & 0,22 & 0,22 & 0,34 & 0,38 & 0,32 & & & 0,12 & 0,212 & 0,191 & 0,23 & 0,36 & 0,29 & & \\
\hline Heteropterys byrsonimifolia A.Juss. & arvo & & & & & & & & & & & & & & & & 0,10 \\
\hline Peixotoa cordistipula A.Juss. & suba & & & & 0,13 & 0,38 & 0,32 & 0,08 & & & 0,053 & 0,143 & 0,14 & 0,27 & 0,53 & 0,36 & \\
\hline MALVACEAE & & & & & & & & & & & & & & & & & \\
\hline Byttneria scalpellata Pohl & erva & & & & & 0,09 & 0,23 & 0,32 & 0,09 & & & & & 0,14 & 0,05 & 0,14 & 0,10 \\
\hline $\begin{array}{l}\text { Eriotheca pubescens (Mart. \& Zucc.) Schott \& } \\
\text { Endl }\end{array}$ & arvo & & 0,11 & 0,13 & 0,21 & 0,21 & 0,18 & 0,08 & 0,09 & & & 0,048 & 0,09 & 0,05 & 0,05 & 0,05 & \\
\hline Pavonia rosa-campestris A.St.-Hil. & suba & 0,69 & 0,38 & 0,48 & 0,42 & 0,68 & 0,59 & 0,52 & 0,36 & 0,87 & 0,850 & 0,765 & 0,74 & 0,59 & 0,97 & 0,68 & 0,52 \\
\hline $\begin{array}{l}\text { Peltae polymorpha (A.St.-Hil.) Krapov. \& } \\
\text { Cristóbal } \\
\text { MELASTOMATACEAE }\end{array}$ & erva & & & & & & & & 0,09 & & & & & & & & \\
\hline Miconia albicans $(\mathrm{Sw}$.$) Triana$ & arbu & & & & & & & & 0,36 & & & & & & & 0,05 & 1,14 \\
\hline Miconia burchellii Triana & arvo & & & & & & & & 0,09 & & & & & & & & \\
\hline Miconia fallax DC. & arbu & 0,44 & & 0,13 & & 0,04 & & 0,16 & & & & & & & & & 0,31 \\
\hline MENISPERMACEAE & & & & & & & & & & & & & & & & & \\
\hline Cissampelos ovalifolia DC. & suba & & 0,11 & & 0,08 & 0,26 & 0,05 & 0,64 & 0,36 & & 0,053 & 0,048 & 0,09 & 0,63 & 0,29 & 0,77 & 0,31 \\
\hline MORACEAE & & & & & & & & & & & & & & & & & \\
\hline Brosimum gaudichaudii Trécul & arvo & & 0,05 & 0,04 & 0,04 & 0,04 & & & 0,09 & 0,12 & 0,106 & 0,143 & 0,05 & 0,14 & 0,10 & 0,09 & \\
\hline Campomanesia adamantium (Cambess.) O.Berg & suba & & & 1,04 & 1,05 & 1,24 & 0,09 & 1,16 & & & & 1,004 & 1,15 & 1,49 & 0,10 & 1,31 & \\
\hline Campomanesia pubescens (Mart. ex DC.) O.Berg & suba & 0,06 & 1,32 & & & & 0,77 & 0,04 & 2,09 & 0,64 & 0,956 & & & & 1,16 & & 0,73 \\
\hline Eugenia calycina Cambess. & suba & 0,13 & 0,11 & 0,09 & 0,21 & 0,21 & 0,23 & 0,16 & 0,09 & 0,06 & 0,106 & 0,048 & 0,05 & 0,23 & 0,58 & 0,36 & 0,21 \\
\hline Eugenia complicata O.Berg & suba & 0,57 & & & & & & & 0,09 & 0,06 & 0,053 & & & & & & \\
\hline Eugenia lutescens Cambess. & suba & 0,13 & & 0,04 & & 0,04 & 0,05 & & & & & & & & & & \\
\hline Eugenia myrcianthes Cambess. & suba & 0,13 & 0,11 & 0,26 & 0,17 & 0,55 & 0,05 & 0,04 & & 0,12 & & 0,048 & 0,37 & 0,18 & 0,10 & 0,14 & 0,10 \\
\hline Myrcia guianensis (Aubl.) DC. & suba & & & & & & & & 0,09 & & & & & & & & \\
\hline Myrcia linearifolia Cambess. & suba & 0,38 & 1,48 & 1,39 & 0,88 & 1,24 & 1,08 & 1,16 & 0,82 & 1,05 & 1,646 & 1,864 & 1,38 & 1,31 & 1,30 & 1,31 & 0,94 \\
\hline Myrcia nivea Cambess. & suba & & & 0,17 & 0,29 & & 0,14 & 0,24 & 0,27 & & & 0,335 & 0,69 & & 0,53 & 0,32 & \\
\hline Myrcia rubella Cambess. & suba & 0,06 & & & & & & & 0,55 & & & & & & & & 0,52 \\
\hline
\end{tabular}




\begin{tabular}{|c|c|c|c|c|c|c|c|c|c|c|c|c|c|c|c|c|c|}
\hline \multirow[t]{2}{*}{ Espécie } & \multirow[t]{2}{*}{ Hábito } & \multicolumn{8}{|c|}{ Área 1} & \multicolumn{8}{|c|}{ Área 2} \\
\hline & & 1988 & 1989 & 1990 & 1991 & 1992 & 1993 & 1994 & 2012 & 1988 & 1989 & 1990 & 1991 & 1992 & 1993 & 1994 & 2012 \\
\hline NI & suba & & & 0,13 & 0,17 & 0,17 & & & & & & 0,287 & 0,09 & 0,05 & & & \\
\hline Psidium grandifolium Mart. ex DC. & suba & & & & & & & & & & & & & & & & 0,10 \\
\hline Psidium laruotteanum Cambess. & arvo & & 0,33 & 0,35 & 0,38 & 0,26 & 0,36 & 0,40 & 0,18 & & & 0,048 & 0,14 & 0,14 & 0,43 & 0,23 & \\
\hline Psidium myrsinites DC. & arvo & & 0,11 & & & & 0,09 & 0,12 & & & & & & & & 0,05 & \\
\hline Psidium sp & suba & 0,63 & & & 0,08 & & 0,54 & 0,24 & 0,46 & 0,06 & & & 0,09 & 0,18 & & 0,36 & 0,73 \\
\hline NYCTAGINACEAE & & & & & & & & & & & & & & & & & \\
\hline Guapira graciliflora (Mart. ex Schmidt) Lundell & arvo & 1,64 & 1,15 & 1,04 & 1,05 & 1,45 & 1,04 & 1,80 & 1,37 & & 0,372 & 0,335 & 0,28 & 0,59 & 0,19 & 0,36 & 0,62 \\
\hline $\begin{array}{l}\text { Guapira noxia (Netto) Lundell } \\
\text { OCHNACEAE }\end{array}$ & arvo & 0,25 & 0,38 & 0,70 & 0,80 & 0,30 & 0,86 & 0,52 & 0,27 & 0,81 & 0,319 & 0,908 & 1,15 & 0,99 & 1,40 & 0,90 & 0,10 \\
\hline Ouratea floribunda (A.St.-Hil.) Engl. & suba & & & & & & & & 0,09 & & & & & & & & 0,21 \\
\hline $\begin{array}{l}\text { Ouratea hexasperma (A.St.-Hil.) Baill. } \\
\text { OPILIACEAE }\end{array}$ & arvo & 0,76 & 0,49 & 0,43 & 0,84 & 0,72 & 0,81 & 0,92 & 0,73 & 0,52 & 0,637 & 0,574 & 0,46 & 0,59 & 0,58 & 0,54 & \\
\hline $\begin{array}{l}\text { Agonandra brasiliensis Miers ex Benth. \& } \\
\text { Hook.f. } \\
\text { ORCHIDACEAE }\end{array}$ & arvo & & & & & & 0,05 & & & & & & & & & & \\
\hline $\begin{array}{l}\text { Cyrtopodium eugenii Rchb.f. } \\
\text { OXALIDACEAE }\end{array}$ & Erva & & & 0,04 & & 0,13 & 0,05 & & & & & & & & & & \\
\hline Oxalis densifolia Mart. \& Zucc. ex Zucc. & erva & & & & & & & & 0,09 & & & & & & & & \\
\hline $\begin{array}{l}\text { Oxalis suborbiculata Lourteig } \\
\text { POACEAE }\end{array}$ & erva & & 0,11 & 0,35 & 0,25 & 0,47 & 0,45 & 0,88 & 0,36 & & 0,106 & 0,096 & 0,14 & 0,14 & 0,48 & 0,59 & 0,42 \\
\hline Agenium sp & erva & 1,26 & 1,98 & 3,87 & 3,79 & 3,71 & 3,29 & 2,27 & & 0,06 & 2,868 & 4,541 & 3,23 & 3,43 & 2,51 & 2,07 & \\
\hline Aristida recurvata Kunth & erva & 0,38 & 0,55 & 2,48 & 1,39 & 1,92 & 0,68 & 2,71 & 0,09 & 0,70 & 0,690 & 1,960 & 1,29 & 0,95 & 0,72 & 0,63 & 0,62 \\
\hline Axonopus argentinus Parodi & erva & & & & 0,04 & 0,04 & 0,09 & & & 0,06 & 0,053 & 0,048 & 0,18 & 0,18 & 0,14 & 0,09 & \\
\hline Axonopus barbigerus (Kunth) Hitchc. & erva & 9,77 & 9,29 & 6,13 & 7,29 & 6,87 & 6,26 & 6,15 & 3,55 & 10,41 & 8,019 & 5,641 & 6,51 & 6,28 & 4,63 & 5,00 & 4,06 \\
\hline Axonopus marginatus (Trin.) Chase & erva & 8,63 & 9,51 & 7,43 & 7,88 & 7,42 & 7,66 & 5,75 & 10,20 & 10,23 & 9,825 & 8,509 & 8,72 & 8,49 & 7,92 & 6,04 & 4,89 \\
\hline Melinis minutiflora P.Beauv. & erva & & & & & & & & & & & & & & & & 0,31 \\
\hline Ctenium chapadense (Trin.) Döll & erva & & & 0,09 & & 0,17 & & 0,28 & & & & & & 0,09 & 0,10 & & \\
\hline Digitaria insularis (L.) Fedde & erva & & & 0,17 & & 0,13 & 0,05 & & & 0,81 & 0,159 & 0,621 & 0,18 & 0,45 & 0,58 & 0,23 & \\
\hline Echinolaena inflexa (Poir.) Chase & erva & 12,29 & 10,49 & 8,26 & 8,05 & 8,19 & 8,69 & 7,46 & 17,30 & 11,51 & 10,196 & 9,226 & 9,14 & 8,94 & 9,56 & 8,83 & 19,98 \\
\hline Elionurus muticus (Spreng.) Kuntze & erva & 1,20 & 0,16 & 0,39 & 0,13 & 0,09 & & & & 2,79 & 0,531 & 0,908 & 0,42 & 0,36 & 0,72 & 0,45 & \\
\hline NI & erva & & & & & & & & 0,09 & & & & & & & & \\
\hline Gymnopogon spicatus (Spreng.) Kuntze & erva & & 0,11 & 0,09 & & & & & & & & & & & & & \\
\hline $\begin{array}{l}\text { Hyparrhenia bracteata (Humb. \& Bonpl. ex } \\
\text { Willd.) Stapf }\end{array}$ & erva & & & & & & & & 0,55 & & & & & & & & \\
\hline Mesosetum loliiforme (Hochst.) Chase & erva & & 0,88 & 0,30 & 0,59 & 0,47 & 0,63 & 0,72 & & & 0,053 & 0,096 & 0,14 & 0,23 & 0,05 & 0,18 & \\
\hline Panicum cervicatum Chase & erva & 0,69 & 0,44 & 0,65 & 0,08 & 0,17 & 0,09 & & & 0,81 & 0,690 & 0,430 & 0,42 & 0,09 & 0,34 & 0,18 & 0,10 \\
\hline Paspalum erianthum Nees ex Trin. & erva & & 0,11 & & 0,38 & & 0,14 & 0,16 & 0,36 & 0,12 & 0,425 & 0,096 & 0,51 & 0,27 & 0,10 & 0,23 & 0,62 \\
\hline Paspalum gardnerianum Nees & erva & 0,32 & 0,11 & 0,17 & & 0,13 & & 0,08 & & 0,23 & 0,106 & 0,096 & & & 0,39 & 0,09 & \\
\hline
\end{tabular}




\begin{tabular}{|c|c|c|c|c|c|c|c|c|c|c|c|c|c|c|c|c|c|}
\hline \multirow[t]{2}{*}{ Espécie } & \multirow[t]{2}{*}{ Hábito } & \multicolumn{8}{|c|}{ Área 1} & \multicolumn{8}{|c|}{ Área 2} \\
\hline & & 1988 & 1989 & 1990 & 1991 & 1992 & 1993 & 1994 & 2012 & 1988 & 1989 & 1990 & 1991 & 1992 & 1993 & 1994 & 2012 \\
\hline Paspalum pectinatum Nees ex Trin. & erva & 0,06 & & & & & & & & & 0,106 & & 0,18 & & & & \\
\hline Schizachyrium condensatum (Kunth) Nees & erva & 0,76 & & 0,26 & 0,17 & 0,72 & 0,18 & 1,44 & 0,18 & 0,81 & & & 0,09 & & 0,19 & 0,05 & 0,10 \\
\hline Schizachyrium tenerum Nees & erva & 11,28 & 5,05 & 5,22 & 4,42 & 3,84 & 3,60 & 4,67 & 1,82 & 9,19 & 7,382 & 3,155 & 3,37 & 2,84 & 2,51 & 2,48 & 1,46 \\
\hline Schizachyrium sanguineum (Retz.) Alston & erva & 0,88 & 0,27 & 0,96 & 0,04 & 0,55 & & 0,12 & & 1,28 & 0,212 & 0,096 & & 0,14 & 0,14 & 0,50 & \\
\hline Trachypogon sp & erva & 1,39 & 2,53 & 5,78 & 7,46 & 7,85 & 8,29 & 6,90 & 10,56 & 2,38 & 4,408 & 5,545 & 7,71 & 8,13 & 8,64 & 8,02 & 10,61 \\
\hline POLYGALACEAE & & & & & & & & & & & & & & & & & \\
\hline Monnina sp & suba & & & & & 0,13 & 0,05 & & & & & & & & & & \\
\hline PRIMULACEAE & & & & & & & & & & & & & & & & & \\
\hline Cybianthus gardneri (A.DC.) G.Agostini & arbu & & & & & 0,17 & 0,18 & 0,20 & & & & & & & & & 0,31 \\
\hline $\begin{array}{l}\text { Myrsine guianensis (Aubl.) Kuntze } \\
\text { PROTEACEAE }\end{array}$ & arvo & 2,39 & 1,81 & 1,43 & 1,60 & 1,71 & 2,75 & 2,00 & 4,83 & 3,26 & 3,611 & 2,772 & 2,86 & 2,80 & 3,43 & 3,74 & 4,89 \\
\hline $\begin{array}{l}\text { Roupala montana Aubl. } \\
\text { RUBIACEAE }\end{array}$ & arvo & 1,13 & 1,10 & 0,78 & 0,93 & 0,94 & 0,72 & 0,84 & 1,64 & 0,23 & 0,478 & 0,382 & 0,18 & 0,32 & 0,34 & 0,45 & 0,73 \\
\hline Chomelia ribesioides Benth. ex A.Gray & arbu & & 0,11 & 0,13 & 0,13 & 0,13 & 0,14 & 0,12 & & 0,23 & 0,212 & 0,239 & 0,18 & 0,23 & 0,24 & 0,18 & 0,10 \\
\hline Palicourea rigida Kunth & arvo & 0,44 & 0,60 & 0,61 & 0,84 & 0,68 & 0,81 & 0,84 & 0,46 & & 0,053 & 0,191 & 0,14 & 0,27 & 0,34 & 0,32 & \\
\hline Sabicea brasiliensis Wernham & suba & 0,82 & 0,82 & 0,56 & 0,42 & 0,64 & 0,36 & 0,44 & 1,18 & 0,99 & 0,797 & 0,621 & 0,60 & 0,59 & 0,82 & 0,81 & 0,62 \\
\hline $\begin{array}{l}\text { Planaltina capitata (K.Schum.) R.M. Salas \& } \\
\text { E.L. Cabral }\end{array}$ & suba & & 0,99 & 0,87 & 1,31 & 1,15 & 1,67 & 0,68 & 0,36 & & 1,168 & 0,813 & 1,02 & 0,54 & 1,79 & 1,22 & 0,83 \\
\hline $\begin{array}{l}\text { Tocoyena formosa (Cham. \& Schltdl.) K.Schum. } \\
\text { RUTACEAE }\end{array}$ & arvo & & & 0,04 & 0,04 & 0,09 & 0,18 & 0,08 & & 0,06 & & & 0,05 & 0,05 & 0,10 & 0,14 & \\
\hline Esenbeckia pumila Pohl & arbu & 0,82 & 0,49 & 1,04 & 0,76 & 0,81 & 0,81 & 0,52 & 1,09 & 2,21 & 1,912 & 2,008 & 1,62 & 2,08 & 1,35 & 3,02 & 2,19 \\
\hline $\begin{array}{l}\text { Spiranthera odoratissima A.St.-Hil. } \\
\text { SALICACEAE }\end{array}$ & suba & 0,38 & 0,49 & 0,56 & 0,38 & 0,30 & 0,77 & 0,32 & 0,18 & 0,12 & & 0,048 & 0,05 & 0,05 & 0,05 & 0,09 & \\
\hline Casearia altiplanensis Sleumer & suba & 0,95 & 3,02 & 1,87 & 2,70 & 1,75 & 3,11 & 2,71 & 1,73 & 2,33 & 3,452 & 3,203 & 3,78 & 2,93 & 3,91 & 3,65 & 0,83 \\
\hline $\begin{array}{l}\text { Casearia sylvestris } \mathrm{Sw} . \\
\text { SAPINDACEAE }\end{array}$ & arvo & 0,32 & 0,55 & 0,65 & 0,46 & 0,60 & 1,04 & 0,76 & 1,73 & 0,29 & 0,690 & 0,574 & 0,37 & 0,27 & 0,29 & 0,63 & 0,83 \\
\hline $\begin{array}{l}\text { Serjania reticulata Cambess. } \\
\text { SAPOTACEAE }\end{array}$ & trep & & & & & & & 0,04 & & & & & & & 0,05 & 0,05 & \\
\hline $\begin{array}{l}\text { Pouteria ramiflora (Mart.) Radlk. } \\
\text { SIMAROUBACEAE }\end{array}$ & arvo & & 0,05 & 0,04 & 0,08 & 0,09 & 0,09 & 0,04 & & & 0,106 & & & & & & \\
\hline $\begin{array}{l}\text { Simaba sp } \\
\text { SMILACACEAE }\end{array}$ & suba & & & & & & 0,23 & & & & & & & & & & \\
\hline $\begin{array}{l}\text { Smilax brasiliensis Spreng. } \\
\text { SOLANACEAE }\end{array}$ & trep & 0,38 & 0,22 & 0,13 & 0,38 & 0,26 & 0,32 & 0,32 & 0,73 & 0,29 & 0,319 & 0,335 & 0,18 & 0,27 & 0,34 & 0,18 & 0,10 \\
\hline $\begin{array}{l}\text { Solanum subumbellatum Vell. } \\
\text { STYRACACEAE }\end{array}$ & suba & & & & & & & & 0,27 & & & & & & & 0,05 & 0,21 \\
\hline $\begin{array}{l}\text { Styrax ferrugineus Nees \& Mart. } \\
\text { SYMPLOCACEAE }\end{array}$ & arvo & 1,20 & 0,66 & 0,65 & 0,80 & 0,98 & 0,41 & 0,56 & 0,46 & 0,29 & 0,212 & 0,287 & 0,37 & 0,41 & 0,29 & 0,23 & \\
\hline
\end{tabular}




\begin{tabular}{|c|c|c|c|c|c|c|c|c|c|c|c|c|c|c|c|c|c|}
\hline \multirow[t]{2}{*}{ Espécie } & \multirow[t]{2}{*}{ Hábito } & \multicolumn{8}{|c|}{ Área 1} & \multicolumn{8}{|c|}{ Área 2} \\
\hline & & 1988 & 1989 & 1990 & 1991 & 1992 & 1993 & 1994 & 2012 & 1988 & 1989 & 1990 & 1991 & 1992 & 1993 & 1994 & 2012 \\
\hline $\begin{array}{l}\text { Symplocus rhamnifolia A.DC. } \\
\text { TURNERACEAE }\end{array}$ & arvo & & 0,11 & & & & & 0,04 & & & & & & & & & \\
\hline $\begin{array}{l}\text { Piriqueta sidifolia (Cambess.) Urb. } \\
\text { VELLOZIACEAE }\end{array}$ & suba & & & & & & 0,09 & & 0,09 & & & & & 0,09 & & 0,14 & 0,10 \\
\hline Vellozia squamata Pohl & arbu & 0,06 & 0,05 & 0,09 & 0,13 & 0,13 & 0,14 & 0,12 & & 0,06 & 0,106 & 0,096 & 0,09 & 0,05 & 0,10 & 0,14 & 0,10 \\
\hline $\begin{array}{l}\text { VOCHYSIACEAE } \\
\text { Qualea multiflora Mart. }\end{array}$ & arvo & & & & & & 0,05 & & & & & & & & & & \\
\hline $\begin{array}{l}\text { Qualea parviflora Mart. } \\
\text { Salvertia convallariodora A.St.-Hil. }\end{array}$ & $\begin{array}{l}\text { arvo } \\
\text { arvo }\end{array}$ & 0,06 & & 0,09 & 0,08 & & & 0,12 & 0,18 & & & & 0,05 & 0,09 & 0,05 & & \\
\hline $\begin{array}{l}\text { Vochysia elliptica Mart. } \\
\text { Vochysia thyrsoidea } \text { Pohl }\end{array}$ & $\begin{array}{l}\text { arvo } \\
\text { arvo }\end{array}$ & & & & & 0,04 & 0,05 & 0,04 & & & 0,053 & 0,048 & 0,09 & 0,09 & 0,14 & 0,05 & \\
\hline Total & & 100 & 100 & 100 & 100 & 100 & 100 & 100 & 100 & 100 & 100 & 100 & 100 & 100 & 100 & 100 & 100 \\
\hline
\end{tabular}

